\title{
A construção do perfil do assistente social no cenário educacional
}

\author{
Maria Cristina Piana
}

PIANA, MC. A construção do perfil do assistente social no cenário educacional [online]. São Paulo: Editora UNESP; São Paulo: Cultura Acadêmica, 2009. 233 p. ISBN 978-85-7983-038-9. Available from SciELO Books <http://books.scielo.org>.

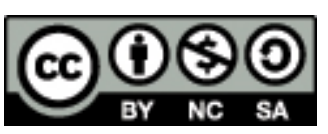

All the contents of this chapter, except where otherwise noted, is licensed under a Creative Commons Attribution-Non Commercial-ShareAlike 3.0 Unported.

Todo o conteúdo deste capítulo, exceto quando houver ressalva, é publicado sob a licença Creative Commons Atribuição Uso Não Comercial - Partilha nos Mesmos Termos 3.0 Não adaptada.

Todo el contenido de este capítulo, excepto donde se indique lo contrario, está bajo licencia de la licencia Creative Commons Reconocimento-NoComercial-CompartirIgual 3.0 Unported. 


\section{A CONSTRUÇÃ̄o DO PERFIL DO ASSISTENTE SOCIAL NO CENARIO EDUCACIONAL}

MARIA CRISTINA PIANA 


\section{A construeção do PERFIL DO ASSISTENTE SOCIAL NO CENÁRIO EDUCACIONAL}



MARIA CRISTINA PIANA

\section{A construção do PERFIL DO ASSISTENTE SOCIAL NO CENÁRIO EDUCACIONAL}


(C) 2009 Editora UNESP

\section{Cultura Acadêmica}

Praça da Sé, 108

01001-900 - São Paulo - SP

Tel.: (0xx11) 3242-7171

Fax: (0xx11) 3242-7172

www.editoraunesp.com.br

feu@editora.unesp.br

CIP - Brasil. Catalogação na fonte

Sindicato Nacional dos Editores de Livros, RJ

\section{P643c}

Piana, Maria Cristina

A construção do perfil do assistente social no cenário educacional / Maria

Cristina Piana. - São Paulo : Cultura Acadêmica, 2009.

Inclui bibliografia

ISBN 978-85-7983-038-9

1. Serviço social escolar. 2. Serviço social - Orientação profissional.

3. Educação e Estado. 4. Política social - Barretos (SP). I. Título.

09-6244.

CDD: 361.38

CDU: $364.4: 37$

Este livro é publicado pelo Programa de Publicações Digitais da Pró-Reitoria de Pós-Graduação da Universidade Estadual Paulista "Júlio de Mesquita Filho" (UNESP)

Editora afiliada:

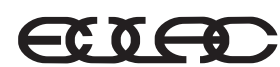

Asociación de Editoriales Universitarias de América Latina y el Caribe

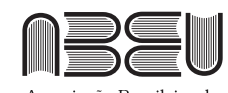

Associação Brasileira de Editoras Universitárias 
À minha família e à amiga Lúcia pela conquista. 



\section{Agradecimentos}

Ao professor José Walter Canoas, pelas orientações com grande sabedoria, incentivo, apoio e dedicação durante o percurso dessa conquista.

A todas as pessoas que participaram direta e indiretamente da construção de minha história pessoal e profissional.

A meus mestres e professores que, desde a minha tenra idade, contribuíram para minha paixão pelo conhecimento e a busca incansável.

A meus amigos que garantiram presença sensível e amorosa nos momentos mais difíceis.

À amiga Lúcia, um ser humano bondoso e uma profissional competente e comprometida na busca da transformação social.

A meu pai, minha mãe e meus irmãos, que marcam minha vida pela experiência do amor recíproco no seio familiar.

E à infalível presença e inspiração de Deus. 

Pedras no caminho?

Guarde todas; um dia construirá um castelo.

Fernando Pessoa 



\section{SUMÁRIO}

Introdução 13

1 As políticas sociais no contexto brasileiro: natureza e desenvolvimento 21

2 As políticas educacionais: dos princípios de organização à proposta da democratização 57

3 O Serviço Social na contemporaneidade: demandas e respostas 85

4 A construção da pesquisa documental: avanços e desafios na atuação do Serviço Social no campo educacional 119

5 A pesquisa de campo 167

Conclusão 211

Referências bibliográficas 219 



\section{INTRODUÇÃO}

"Viva como se fosse morrer amanhã, mas estude como se você não fosse morrer nunca"

Santo Izidoro

A proposta da presente pesquisa consiste em conhecer e compreender o trabalho do Serviço Social na Educação brasileira para explicar o percurso do trabalho desenvolvido pelo Serviço Social, desde 2003 na Secretaria de Educação da cidade de Barretos/SP.

O estudo sobre a atuação do Serviço Social na Educação e o perfil profissional no cenário educacional, com olhar para o trabalho desenvolvido no município de Barretos, vem responder à curiosidade científica da pesquisadora em desvendar o trabalho desenvolvido pelo Serviço Social nessa política social garantida como direito social a todo cidadão e o objeto de estudo e intervenção dos assistentes sociais desde a origem da profissão no início do século XX.

A preocupação em torno da não efetivação da educação como um direito social garantido a todas as crianças, a adolescentes e jovens de baixa renda do País, justifica-se, inicialmente, pela inquietude da pesquisadora, desde o início de sua atuação profissional, durante esses 20 anos, com crianças e adolescentes e suas famílias, em vários projetos socioeducativos de diferentes municípios brasileiros onde a 
pesquisadora morou, culminando em sua atuação como conselheira tutelar na gestão 1999 a 2002, no município de Barretos/SP. Esse trabalho despertou o interesse pelo estudo sobre essa temática, a educação, vindo se concretizar com o trabalho de mestrado, sobre a análise da atuação do Conselho Tutelar frente à evasão escolar de adolescentes no município de Barretos/SP, no ano de 2003.

A experiência da pesquisadora, no órgão municipal, colocou-a frente ao sério questionamento da educação, como afirma Demo (2000d, p.58), “[...] deparamo-nos com um povo que não sabe pensar, escrever nem tão pouco ler a realidade politicamente, impedindo de tornar-se sujeito da história". Tantos adolescentes e jovens sem perspectiva de vida, sem uma carreira profissional de sucesso e sem formação acadêmica.

Diante dessas interrogações e apelos profissionais, surgiu junto à enriquecedora sugestão da Banca Examinadora de Mestrado, a proposta de continuar a pesquisa na área da educação, culminando nesse estudo. Assim, acredita-se que, nessa tarefa da educação como responsabilidade do Estado, das instituições escolares e da sociedade em geral, inserem-se o pensamento e a ação interdisciplinar, ressaltando-se o compromisso fundamental do trabalhador social, ou seja, do assistente social nesse trabalho.

Por meio da realização de pesquisas por meio dos cursos de pósgraduação, especialização/lato sensu e mestrado/stricto sensu, a pesquisadora conseguiu desenvolver investigações sobre o Serviço Social na Educação revelando a importância da atuação desse profissional na área de gestão, elaboração e implementação dessa política social, a educação. A concretização da dissertação de mestrado trouxe um impulso e motivação à pesquisa. Esse estudo mostrou a necessidade de os profissionais construírem um perfil profissional no cenário educacional, de agregarem maior conhecimento dessa política social de direito público, da análise do contexto social, político e econômico em que se insere a Educação, visando garantir a competência da atuação profissional, além de garantir o Serviço Social definitivamente, nas legislações nacionais e buscar o espaço de trabalho nas instituições de ensino e na elaboração das diretrizes e planos municipais, estaduais e federais tão complexos. 
No ano de 2007, a pesquisadora, enquanto docente do curso de Serviço Social do Centro Universitário da Fundação Educacional de Barretos (Unifeb) Barretos/SP, ministrando disciplinas pertencentes ao Núcleo de Fundamentos do Trabalho Profissional, interpelada com questões relacionadas ao trabalho profissional e a partir de solicitações de dirigentes da educação municipal, precisamente dos projetos socioeducativos relacionados a uma política educacional de período integral, elaborou um projeto social propondo a atuação do Serviço Social nessas modalidades, objetivando conquistar outro espaço na política educacional de Barretos. O trabalho encontra-se em construção, porém é revelado como importante, segundo os gestores dessa política, recebendo apoios irrestritos para sua possível ampliação. Nesse sentido, a pesquisadora tornou-se supervisora de estágio de campo, desenvolvendo com vários alunos do curso de Serviço Social um trabalho de conquista de espaço, um conhecimento da profissão por parte dos profissionais da educação e seus usuários e a efetivação do trabalho.

Outro aspecto relevante nesse trabalho é a realização de dois Fóruns de discussão sobre a importância do Serviço Social na Educação de Barretos, realizados no ano de 2008, por meio da coordenação do curso de Serviço Social da Unifeb - Barretos/SP, do qual a pesquisadora faz parte. Tais eventos objetivaram fomentar a discussão e a proposta da elaboração de uma lei municipal que garanta a atuação do Serviço Social na Educação de Barretos.

Assim, a pesquisadora deu início a outras sondagens em direção ao universo educacional.

Tendo em vista que os resultados do trabalho do assistente social na política educacional brasileira dependem do conhecimento sobre a organização e a estrutura do sistema de ensino no Brasil, dos acordos políticos nacionais e internacionais nessa área e dos investimentos governamentais nas políticas sociais à população, decidiu-se, então, iniciar nova investigação com o propósito de conhecer o trabalho do Serviço Social na Secretaria Municipal de Barretos, desde os primórdios da institucionalização do Serviço Social no Brasil e no mundo.

Dando início à investigação, definiu-se o objeto de estudo da presente pesquisa: o Serviço Social na Secretaria Municipal de Barretos/ 
SP, estando vinculado ao trabalho que os profissionais sociais vêm desenvolvendo nesse campo de atuação profissional nas várias localidades do País e o perfil do assistente social que está sendo traçado no cenário educacional.

A pesquisa sobre o trabalho do Serviço Social na educação pode oferecer elementos importantes para o meio acadêmico, na construção do conhecimento, além de contribuir para o processo de formação profissional a partir de reflexões sobre a realidade do Brasil e da cidade de Barretos/SP.

Essa temática ganha especial significado por tratar de um estudo voltado para o mundo da educação que representa hoje uma exigência do sistema vigente em termos de qualidade, novos empreendedorismos, investimentos em pessoal, formação continuada e generalista.

O estudo foi realizado por meio de pesquisa teórica, documental e de campo o que possibilitou a caracterização da cidade de Barretos, em seus avanços e peculiaridades, e o trabalho desenvolvido pelo profissional de Serviço Social na educação, além dos projetos de lei que estão sendo construídos nas três esferas para a implementação de um aparato legal ao trabalho social e a busca da construção do perfil do assistente social na educação.

O universo da pesquisa ficou constituído pela Secretaria de Educação do município de Barretos/SP. E a pesquisadora julgou importante buscar uma realidade complementar que objetivou acrescentar informações e proposições ao trabalho de Barretos, por tratar-se de um trabalho incipiente e em construção. O município de Osasco/ SP foi escolhido pela pesquisadora e seu orientador para contribuir nas análises da atuação do Serviço Social, visto que este conta com um trabalho estruturado e com avanços nessa área.

A presença do Serviço Social na Política Educacional surgiu, historicamente no mundo, em 1906, nos Estados Unidos e no Brasil, com os primeiros trabalhos que os profissionais realizavam nas décadas de 1940 e 1950, embora voltados para os trabalhos realizados com os "menores carentes" assim denominados pelo contexto social vigente. O trabalho teve seus avanços e, dessa forma, muitos estados e municípios brasileiros organizaram e sistematizaram trabalhos 
de atuação do assistente social nas escolas, em projetos sociais não escolares, na educação superior e em equipes interdisciplinares de assessoria e elaboração de diretrizes, de normas e de planos de ação para a atuação na educação.

Busca-se hoje um redimensionamento da atuação do Serviço Social na educação, visando, a partir das diversas experiências de atuação profissional, extrapolar o ambiente escolar, ampliando a concepção que se tem de educação hoje, do processo pedagógico em geral, do ensino-aprendizagem, da figura da escola e da articulação da educação com as demais políticas sociais. $\mathrm{O}$ assistente social deve propor uma ação coletiva interdisciplinar com outros profissionais do ensino, com os familiares dos alunos e com a comunidade em geral.

Dessa forma, a escolha pela cidade de Barretos, como lócus privilegiado da pesquisa, justifica-se porque a pesquisadora reside neste município e desenvolveu vários trabalhos com a população infanto-juvenil, além do Conselho Tutelar e atualmente iniciou um trabalho, como supervisora de campo, com os adolescentes e jovens dos bairros São Francisco e Santa Cecília para a elaboração do projeto de primeiro emprego junto a essa população de baixa renda.

Para a realização da pesquisa, foi necessário selecionar a amostra não probabilística, intencionalmente constituída pelo Serviço Social da Secretaria Municipal de Educação.

Os sujeitos foram selecionados a partir de critérios pré-elaborados como: profissionais que exercem cargos de chefia na Secretaria de Educação e estão ligados ao setor ou departamento de Serviço Social. Ficaram representados pela secretária da Educação, pela supervisora geral de educação infantil e pelo profissional social que executa o trabalho. Para a seleção dos profissionais que contribuíram no acréscimo da pesquisa, foram seguidos os mesmos critérios.

$\mathrm{Na}$ continuidade do processo de pesquisa, definiu-se o recorte temporal, determinado pelo ano de 2003, por ser o início do trabalho do Serviço Social na Educação de Barretos, quando foi chamada uma profissional pelo concurso público em vigência, até o ano de 2008 e foram concluídas as aplicações das pesquisas para a presente investigação. 
O estudo partiu da hipótese de que o Serviço Social é uma profissão fundamental para trabalhar a garantia da educação como direito social preconizado nas leis brasileiras, independentemente de raça, gênero, crença, poder econômico, político e cultural a todo cidadão. Dessa forma, a profissão de Serviço Social pode contribuir na efetivação desse direito social para todos, por meio da atuação direta nas unidades de ensino e em propostas e elaborações de diretrizes e normas que determinem as políticas educacionais no País e em seu empenho em conhecer a complexidade do campo educacional e preparar-se para tal. Porém, tem-se como grande obstáculo o desconhecimento dos profissionais da educação no trabalho do assistente social e consequentemente a não aceitação desse profissional nos espaços escolares e também, muitas vezes, o despreparo dos próprios assistentes sociais para o trabalho educacional.

$\mathrm{O}$ assistente social é um profissional que trabalha a realidade social e, diante dessas reflexões, faz-se necessário que construa um perfil diferenciado, crítico, reflexivo, criativo, propositivo, inovador e estratégico para as negociações e conquistas no campo educacional.

Na tentativa de facilitar a organização dessa pesquisa, a tese ficou estruturada em cinco capítulos. O primeiro objetivou contextualizar as políticas sociais, por meio da sua origem, características e organização ao longo do processo histórico brasileiro. Também a questão social foi analisada como grande desafio para a implementação de políticas sociais de direito.

No segundo, buscaram-se reflexões sobre as políticas educacionais, abordando dados históricos de sua estruturação e organização até os dias de hoje, por meio das reformas que calcaram propostas de participação e de educação de qualidade.

O terceiro capítulo teve a finalidade de apresentar reflexões acerca da importância do Serviço Social na contemporaneidade. Para isso, o legado histórico da profissão evidencia sua importante existência, perpassando pela qualidade na formação profissional o que reforça seu compromisso ético-político diante das desigualdades sociais do século XXI.

No quarto capítulo, a pesquisa documental é destaque, pois revela dados primordiais da atuação histórica do Serviço Social nas 
escolas, nos projetos comunitários, nas secretarias estaduais por meio de assessorias aos órgãos estatais, nos conselhos de educação e no ensino superior. A dimensão educativa e pedagógica do Serviço Social é ressaltada como resposta ao trabalho especializado na área educacional. São relevantes ainda os projetos de lei em níveis federal, estadual e municipal que foram aprovados e outros em tramitação para aprovação na pretensão de garantir legalmente a inserção do Serviço Social na Política Educacional brasileira.

No último capítulo, a construção e o desenvolvimento da pesquisa de campo. Inicialmente, houve a preocupação em refletir sobre o cenário da investigação, a cidade de Barretos, a opção metodológica que parte de uma perspectiva crítico-dialética, como primeiro momento um estudo exploratório e investigativo da realidade, e a caracterização pela abordagem qualitativa. Também a opção dos sujeitos e dos profissionais entrevistados que acresceram à pesquisa informações de uma outra experiência do Serviço Social na educação. Enfim, tem-se a preocupação em revelar todo percurso metodológico para garantir a coleta de dados e informações acerca do objeto de estudo. A análise e a interpretação de dados contaram com categorias teóricas e a construção de subcategorias que permitiram à pesquisadora o tratamento qualitativo dos dados na busca de conteúdos expressos ou não nos diálogos com os sujeitos.

Finalizando esse estudo, foram apresentados resultados e discussões, destacando resposta ao problema da pesquisa. 



\title{
1 \\ As POLÍTICAS SOCIAIS NO CONTEXTO BRASILEIRO: NATUREZA E DESENVOLVIMENTO
}

\author{
"O que transformou o mundo não foi a uto- \\ pia. Foi a necessidade."
}

José Saramago

O presente capítulo tem como proposta apresentar algumas reflexões sobre o tema complexo, muito discutido e trabalhado pelo Serviço Social brasileiro, que são as políticas sociais.

A partir dos anos 80 (século XX), a profissão passou a ter uma consistente produção sobre o tema.

A análise das políticas sociais tem muitos caminhos a percorrer. Este estudo intenciona apresentar a dinâmica das políticas sociais, bem como suas características, organização e gestão no desenvolvimento do capitalismo e das lutas profissionais e sociais. Por ora, abordará a articulação entre política e economia na sociedade capitalista.

As políticas sociais no Brasil estão relacionadas diretamente às condições vivenciadas pelo País em níveis econômico, político e social. São vistas como mecanismos de manutenção da força de trabalho, em alguns momentos, em outros como conquistas dos trabalhadores, ou como doação das elites dominantes, e ainda como instrumento de garantia do aumento da riqueza ou dos direitos do cidadão (Faleiros, 1991, p.8). 
O Serviço Social, como profissão inserida na divisão sociotécnica do trabalho, deve ser entendido a partir das configurações expressas pelas relações de classe estabelecidas pelo modelo societário, o capitalismo.

Dessa forma, o Serviço Social como uma das profissões responsáveis pela mediação entre Estado, burguesia e classe trabalhadora na implantação e implementação das políticas sociais destinadas a enfrentar a "questão social", que emergiu na primeira metade do século XIX, com o surgimento do pauperismo, na Europa Ocidental (Pastorini, 2007, p.16), é que ganha hoje, novos contornos a partir do complexo cenário formado pelos monopólios e pelo ideário neoliberal.

\section{Origem, características e funções das políticas sociais}

O estudo das políticas sociais, na área de Serviço Social, vem ampliando sua relevância na medida em que estas têm-se constituído como estratégias fundamentais de enfrentamento das manifestações da questão social na sociedade capitalista atual.

Não se pode precisar um período específico do surgimento das primeiras identificações chamadas políticas sociais, visto que, como processo social, elas se originam na confluência dos movimentos de ascensão do capitalismo como a Revolução Industrial, das lutas de classe e do desenvolvimento da intervenção estatal.

Sua origem relaciona-se aos movimentos de massa socialmente democratas e à formação dos estados-nação na Europa Ocidental do final do século XIX, porém sua generalização situa-se na transição do capitalismo concorrencial ${ }^{1}$ para o capitalismo monopolista,

1 Capitalismo concorrencial fase do capitalismo que teve início com aparecimento de máquinas movidas por energia não-humana. Inicia-se na Inglaterra com a máquina a vapor, por volta de 1746 e finda com o início dos monopólios (Behring, 2000, p.32). 
especialmente em sua fase tardia, após a Segunda Guerra Mundial (Behring \& Boschetti, 2006, p.47).

Historicamente, o estudo das políticas sociais deve ser marcado pela necessidade de pensar as políticas sociais como "concessões ou conquistas", na perspectiva marxista (Pastorini, 1997, p.85), a partir de uma ótica da totalidade. Dessa forma, as políticas sociais são entendidas como fruto da dinâmica social, da inter-relação entre os diversos atores, em seus diferentes espaços e a partir dos diversos interesses e relações de força. Surgem como "[...] instrumentos de legitimação e consolidação hegemônica que, contraditoriamente, são permeadas por conquistas da classe trabalhadora" (Montaño, 2007, p.39).

A política econômica e a política social estão relacionadas intrinsecamente com a evolução do capitalismo (conforme proposta de reflexão), fundamentando-se no desenvolvimento contraditório da história (Vieira E., 2007, p.136). Tais políticas vinculam-se à acumulação capitalista e verifica-se, a partir daí, se respondem às necessidades sociais ou não, ou se é mera ilusão.

Segundo Vieira E. (1995, p.15), a acumulação é o “[...] sentido de concentração e de transferência da propriedade dos títulos representativos de riqueza”. As transformações ocorridas nas revoluções industriais acarretaram uma sociedade com um vasto exército de proletários.

A política social ${ }^{2}$ surge no capitalismo com as mobilizações operárias e a partir do século XIX com o surgimento desses movimentos populares, é que ela é compreendida como estratégia governamental. Com a Revolução Industrial na Inglaterra, do século XVIII a meados do século XIX, esta trouxe consequências como a urbanização exacerbada, o crescimento da taxa de natalidade, fecunda o germe da consciência política e social, organizações proletárias, sindicatos, cooperativas na busca de conquistar o acolhimento público e as primeiras

2 A expressão "política social” teve origem entre pensadores alemães de meados do século XIX que criaram, em 1873, uma associação para seu estudo. A partir daí, a expressão passou a ser amplamente utilizada, muitas vezes sem uma clareza conceitual. 
ações de política social. Ainda nesta recente sociedade industrial, inicia-se o conflito entre os interesses do capital e os do trabalho.

Para Vieira E. (1992, p.81), a história do capitalismo testemunha contradição fundamental, de um lado, ininterrupto crescimento do mercado e do consumo e de outro, sua gradativa monopolização. Com isso,

o processo de acumulação do capital impõe à indústria a necessidade de alargar o mercado e de aumentar o consumo, mas o resguardo e o incremento da rentabilidade do capital já invertido exigem de quando em quando limitações de caráter monopolizador, entravando o próprio mercado e tolhendo as novas possibilidades de sua expansão. O abaixamento do nível de vida da população garante ao mesmo tempo uma taxa média de lucro e também a redução do mercado imprescindível à produção.

Dessa forma, pode-se afirmar que não há política social desligada das lutas sociais. De modo geral, o Estado assume algumas das reivindicações populares, ao longo de sua existência histórica. Os direitos sociais dizem respeito inicialmente à consagração jurídica de reivindicações dos trabalhadores. Certamente, não se estende a todas as reivindicações, mas na aceitação do que é conveniente ao grupo dirigente do momento (Vieira, E., 1992, p.23).

E com Faleiros (1991, p.8), pode-se afirmar que:

As políticas sociais ora são vistas como mecanismos de manutenção da força de trabalho, ora como conquista dos trabalhadores, ora como arranjos do bloco no poder ou bloco governante, ora como doação das elites dominantes, ora como instrumento de garantia do aumento da riqueza ou dos direitos do cidadão.

O período que vai de meados do século XIX até os anos de 1930, é marcado predominantemente pelo liberalismo e sustentado pela concepção do trabalho como mercadoria e sua regulação pelo livre mercado. 
O estado liberal é caracterizado pelo indivíduo que busca seu próprio interesse econômico proporcionando o bem-estar coletivo, predomina a liberdade e competitividade, naturaliza a miséria, ${ }^{3}$ mantém um Estado mínimo, ou seja, para os liberais, o Estado deve assumir o papel "neutro" de legislador e árbitro, e desenvolver somente ações complementares ao mercado e as políticas sociais estimulam o ócio e o desperdício e devem ser um paliativo, o que significa que a pobreza deve ser minimizada pela caridade privada. É, portanto, o mercado livre e ilimitado que regula as relações econômicas e sociais e produz o bem comum.

Mediante esses princípios defendidos pelos liberais e assumidos pelo Estado capitalista, o enfrentamento da questão social, neste período, foi sobretudo repressivo, e seguido de algumas mudanças reivindicadas pela classe trabalhadora que foram melhorias tímidas e parciais na vida dos trabalhadores, sem atingir as causas da questão social.

Também as reformas sociais ocorridas no período pós-Segunda Guerra não atingiram esse objetivo. Assim as primeiras ações de políticas sociais ocorrerão na relação de continuidade entre Estado liberal e Estado social. Ambos terão um ponto em comum que é o reconhecimento de direitos sociais sem prejudicar os fundamentos do capitalismo. Isso porque não houve ruptura radical entre o Estado liberal (século XIX) e o Estado social capitalista (século XX). Mas, sim, uma nova visão de Estado, pressionado por mudanças (lutas das classes trabalhadoras), o "velho liberalismo foi cedendo espaço a um liberalismo mais 'social'” (Pereira, 2000a, p.110) e incorporando orientações social-democratas em um novo contexto socioeconômico e da luta de classes, possibilitando uma visão social e, consequentemente, investimentos em políticas sociais (Behring \& Boschetti, 2006, p.63).

O Estado europeu liberal do século XIX reconheceu direitos civis tais como: o direito à vida, à liberdade individual e os direitos de se-

3 Os liberais veem a miséria como natural e insolúvel, pois decorre da imperfectibilidade humana, ou seja, a miséria é compreendida como resultado da moral humana e não como resultado do acesso desigual à riqueza socialmente produtiva (Behring \& Boschetti, 2006, p.62). 
gurança e de propriedade, mas com características de Estado policial e repressor (Pereira 2000a, p.108-9) e assim a população usufruiu especialmente do direito à liberdade e à propriedade.

O fortalecimento e a organização da classe trabalhadora foram determinantes para a mudança da natureza do Estado liberal no final do século XIX (idem), e os ganhos sociais e políticos obtidos mais precisamente no século XX pelos trabalhadores.

A busca da classe operária pela emancipação humana, a socialização da riqueza e uma nova ordem societária garantiram algumas conquistas importantes na dimensão dos direitos políticos tais como: o direito de voto, de organização e a formação de sindicatos e partidos, de livre expressão e manifestação, e de ampliar os direitos sociais.

Desta forma, segundo Behring \& Boschetti (idem, p.64),

a generalização dos direitos políticos é resultado da luta da classe trabalhadora e, se não conseguiu instituir uma nova ordem social, contribuiu significativamente para ampliar os direitos sociais, para tencionar, questionar e mudar o papel do Estado no âmbito do capitalismo a partir do final do século XIX e início do século XX.

Ainda segundo as autoras, o surgimento das políticas sociais foi gradativo e diferenciado entre os países, com base nos movimentos e organizações reivindicatórias da classe trabalhadora e na correlação de forças no âmbito do Estado. A história relata que é no final do século XIX o período em que o Estado capitalista passa a assumir e a realizar ações sociais mais amplas, planejadas e sistematizadas sob caráter de obrigatoriedade (idem).

Assim o século XX vive transformações globais desenfreadas que alteram a vida de bilhões de pessoas no mundo. As transformações no mundo do trabalho determinaram novos padrões de organização e gestão da indústria, novos tipos de relações e contratos de trabalho e comercialização, altos índices de investimentos em avanços tecnológicos e de automação.

O padrão dominante taylorista/fordista, surgido nos anos 30 (século XX), após a chamada Grande Depressão, fundamentado na 
produção maciça de mercadorias em grandes fábricas, concentradas e verticalizadas, com rígido controle do processo de trabalho que reunia grande número de trabalhadores manuais, especializados, relativamente bem pagos e protegidos pela legislação trabalhista, passa a ser substituído ao entrar em crise, e é substituído pela chamada acumulação flexível, ou seja, a descentralização da economia, com o chamado modelo japonês toyotista que supõe um processo de modificações enfeixadas no mote da flexibilização. Este modelo apresenta uma nova racionalidade produtiva como afirma Antunes (1996, p.79-81):

tem-se um sistema que responde imediata e diretamente às demandas que são colocadas e que possui a flexibilidade para alterar o processo produtivo de modo que não se opere com grandes estoques, mas com estoque mínimo; de modo que se tenha um sistema de produção ou de acumulação flexível, que se adeque a essas alterações cotidianas de mercado. Enfim, um processo produtivo flexível que atenda esta ou aquela rigidez característica de produção em linha de montagem do tipo fordista [...]. É então um processo de organização do trabalho fundado numa resposta imediata à demanda, numa organização flexível do trabalho, numa produção integrada e que supõe necessariamente o envolvimento do trabalho, acarretando o estranhamento do trabalhador, sua "alienação" do trabalho que se torna menos despótico e mais manipulatório [...]. Um sistema de produção flexível supõe direitos do trabalhador também flexíveis, ou de forma mais aguda, supõe a eliminação dos direitos do trabalho [...].

Estas transformações afetam as relações de trabalho e o cotidiano do trabalhador, em seus direitos como a educação, a saúde, a habitação, o lazer, a vida privada. Contudo, o que permaneceé o modelo societário capitalista sob o qual ocorrem tais modificações. E assim, este se estabelece, no final do século XX, não mais como concorrencial. E com a Era Imperialista, tem-se uma hegemonia que se efetiva a partir da consolidação de grandes grupos monopolizados (concentração do capital).

O capitalismo monopolista intensifica suas contradições oriundas da organização da produção capitalista, ou seja, sua produção cada 
vez mais socializada é restrita pela concentração mundial de renda por meio de apropriação privada dos produtos do trabalho.

E assim, como afirma Netto (1996b, p.15),

o capitalismo monopolista recoloca, em patamar mais alto, o sistema totalizante de contradições que confere à ordem burguesa os seus traços basilares de exploração, alienação e transitoriedade histórica [...].

A fase monopólica firma-se por meio do controle dos mercados, garantindo maiores lucros aos capitalistas. Com isso ocorrem diversas variações nas instituições capitalistas, tais como: ampliação do sistema bancário e creditício, acordos empresariais para o aumento do lucro por meio do controle dos mercados, formando os chamados cartéis. Surge grande acumulação de lucro, diminuição da taxa média de lucro e a tendência ao subconsumo aumenta. Os setores de grandes concorrências aumentam em seus investimentos demandando o surgimento de novas tecnologias e diminuindo os postos de trabalho.

Tais contradições geram uma concorrência acirrada de vários grupos monopolistas que disputam o mercado nacional e o mercado internacional. Contudo, criam-se mecanismos extraeconômicos de controle, por meio do Estado, na perspectiva neoliberal ou na perspectiva social-democrática, para controlar as ameaças aos lucros dos monopólios.

Todas essas modificações estendem-se em nível planetário no chamado "mundo" de globalização, que se expressa como nova modalidade de dominação imposta pelo capital por meio da intensificação do intercâmbio mundial de mercadorias, preços, ideias, informações, relações de produção, proporcionando mudanças significativas nas relações humanas. Para Netto (1996b, p.91):

A globalização, ainda, vem agudizando o padrão de competitividade intermonopolista e redesenhando o mapa político-econômico do mundo: para assegurar mercados e garantir a realização de superlucros, as grandes corporações têm conduzido processos supranacionais de integração, os megablocos (União Europeia, Nafta, APEC) 
que, até agora, não se apresentam como espaços livres de problemas para a concentração dos interesses do grande capital.

Dessa forma, o fenômeno da globalização se por um lado permite o intercâmbio mundial por meio da maior interação entre os povos, por outro, tem trazido uma série de contradições e divergências: o aumento do desemprego estrutural, ${ }^{4}$ a exclusão social, o aumento da pobreza, guerras políticas e religiosas e outros, ratificando a lógica do capital, que trazem a concentração da riqueza nas mãos dos setores monopolizados e o acirramento da desigualdade social.

Para atenuar as contradições postas pelas "crises cíclicas de superprodução, superacumulação e subconsumo da lógica do capital" (Behring \& Boschetti, 2006, p.71) e manter a ordem, ocultar as consequências nefastas do capitalismo, criam-se mecanismos políticos e econômicos que garantem a reprodução do sistema e formam um amplo aparato ideológico que procura naturalizar e perpetuar este modelo de sociedade. Após a Segunda Guerra Mundial, consolidouse o chamado Estado de Bem-Estar Social (Welfare State) $)^{5}$ e posteriormente o neoliberalismo. ${ }^{6}$

4 O desemprego estrutural é resultante da forma de organização da produção capitalista que gera um excedente de trabalhadores que ficam disponíveis como exército industrial de reserva. $\mathrm{Na}$ sociedade com a potencialização do trabalho decorrente da automação e tecnificação da economia, o desemprego estrutural toma vulto ainda maior (Behring, 2000, p.35).

5 Segundo a literatura especializada, foram três os pilares do Estado de Bem-Estar Social e das políticas sociais correspondentes, no seu período de ouro, 1945 e 1975 :

1. o pleno emprego (masculino), respaldado na propriedade econômica de pósguerra, na doutrina keynesiana e no esquema beveridgiano de seguridade social;

2. a universalização dos serviços sociais, visando atingir a todos indistintamente, de forma incondicional; e

3. a assistência social como forma de proteção, cuja principal função seria a de impedir que segmentos socialmente vulneráveis resvalassem para baixo de uma linha de pobreza legitimada pela sociedade (Pereira, 2000a, p.55).

6 Neoliberalismo, como arcabouço teórico e ideológico não é algo novo. Nasce com o combate implacável, no início da década de 1940, às teses keynesianas e ao ideário do Estado de Bem-Estar, sobretudo aos direitos sociais e aos ganhos de produtividade da classe trabalhadora. Seu postulado fundamental é de que o mercado é a lei social soberana. Friederich Hayek, teórico principal 
O ideário do Estado de Bem-Estar Social é proposto pela teoria keynesiana em países da Europa e nos Estados Unidos da América que tinha como princípio de ação o pleno emprego e a menor desigualdade social entre os cidadãos. É erigido pela concepção de que os governos são responsáveis pela garantia de um mínimo padrão de vida para todos os cidadãos, como direito social. É baseado no mercado, contudo com ampla interferência do Estado que deve regular a economia de mercado de modo a assegurar o pleno emprego, a criação de serviços sociais de consumo coletivo, como a educação, saúde e assistência social para atender a casos de extrema necessidade e minimizar a pobreza.

Assim afirma Faleiros (1991, p.20),

é pelo Estado Bem-Estar que o Estado garante ao cidadão a oportunidade de acesso gratuito a certos serviços e a prestação de benefícios mínimos para todos. Nos Estados Unidos, esses benefícios dependem de critérios rigorosos de pobreza e os serviços de saúde não são estatizados, havendo serviços de saúde para os velhos e pobres. $\mathrm{O}$ "acesso geral" à educação, à saúde e à justiça existente na Europa decorre de direitos estabelecidos numa vasta legislação que se justifica em nome da cidadania. O cidadão é um sujeito de direitos sociais que tem igualdade de tratamento perante as políticas sociais existentes.

Com essa realidade, ampliaram-se as funções econômicas e sociais do Estado que passou a controlar parcialmente a produção e a assumir despesas sociais. Essas transformações do Estado foram de acordo com a força do movimento trabalhista e ocorreram nos chamados países desenvolvidos da Europa e nos Estados Unidos.

do neoliberalismo expõe suas teses básicas no início da década de 1940. A ele se juntam, entre outros, M. Friedman, e K. Popper. A adoção das teses neoliberais e a implementação econômica e político-social têm início, todavia, apenas no contexto da crise e do colapso do socialismo real. É uma ideologia capitalista que defende o ajuste dos Estados nacionais às exigências do capital transnacionalizado, portanto, contrária aos pactos que subordinam o capital a qualquer forma de soberania popular ou instituições de interesse público. 
O Estado de Bem-Estar Social buscou assegurar um acordo de neutralidade nas relações das classes sociais e amortecer a crise do capitalismo com a sustentação pública de um conjunto de medidas anticrise. Entretanto, foram beneficiados os interesses monopólicos. E como afirmam Behring \& Boschetti (2006, p.71),

As políticas sociais se generalizam nesse contexto, compondo o rol de medidas anticíclicas do período, e também foram o resultado de um pacto social estabelecido nos anos subsequentes com segmentos do movimento operário, sem o qual não podem ser compreendidas.

Nos chamados países pobres e dependentes da América Latina, especialmente no Brasil, nunca ocorreu a garantia do bem-estar da população por meio da universalização de direitos e serviços públicos de qualidade. ${ }^{7}$ Segundo Faleiros (1991, p.28),

Nos países pobres periféricos não existe o Welfare State nem um pleno keynesianismo em política. Devido à profunda desigualdade de classes, as políticas sociais não são de acesso universal, decorrentes do fato da residência no país ou da cidadania. São políticas "categoriais", isto é, que tem como alvo certas categorias específicas da população, como trabalhadores (seguros), crianças (alimentos, vacinas) desnutridas (distribuição de leite), certos tipos de doentes (hansenianos, por exemplo), através de programas criados a cada gestão governamental, segundo critérios clientelísticos e burocráticos. Na América Latina, há grande diversidade na implantação de políticas sociais, de acordo com cada país [...].

A década de 1970 enfrentou o declínio do padrão de bem-estar por meio da crise capitalista agravada pelos reduzidos índices de crescimento com altas taxas de inflação. A regulamentação do mercado

7 Não será aprofundada essa realidade brasileira, considerando que o objetivo deste capítulo é apresentar sucintamente a trajetória das políticas sociais no Brasil, não visando aprofundamento. 
por parte do Estado e o avanço da organização dos trabalhadores passam a ser considerados entraves à livre acumulação de capitais.

Na década seguinte, com a queda dos regimes socialistas ${ }^{8}$ do leste europeu, a crise fiscal do Estado de Bem-Estar e a estagnação da economia ganham forças e os argumentos neoliberais recuperando as ideias liberais propõem a mínima regulamentação do mercado e a ampla liberdade econômica dos agentes produtivos.

Com o avanço das ideias neoliberais, ganha espaço o discurso vitorioso do capitalismo. Tem-se uma realidade ideológica em defesa dos interesses do capital, favorecendo grupos monopolizados, em detrimento dos trabalhadores, realidade essa, velada por um discurso de direitos individuais, tem-se a naturalização da desigualdade social, a busca pela eficiência e competitividade no mundo da globalização. O que segundo Sposati (2000, p.64):

O maior impacto da globalização se manifesta na desregulamentação da força de trabalho, no achatamento de salários e no aumento do desemprego. Esta é a face perversa da globalização, pois em vez de traduzir melhores condições aos povos, ela vem trazendo a globalização da indiferença com os excluídos.

O neoliberalismo passou a ditar o ideário de um projeto societário a ser implementado nos países capitalistas para restaurar o crescimento estável. Tendo como assertivas a reestruturação produtiva, a privatização acelerada, o enxugamento do Estado, as políticas fiscais e monetárias sintonizadas com os organismos mundiais de hegemonia do capital como o Fundo Monetário Internacional (FMI).

8 O modelo socialista estruturou-se a partir de uma ideia de sociedade em que os principais recursos econômicos estivessem sob o controle das classes trabalhadoras; em que a gestão do Estado tinha como objetivo promover a igualdade social e tão somente a igualdade política e jurídica; em que o direito de propriedade passava a ser fortemente limitado; em que houvesse uma rígida planificação da economia, com a manutenção de serviços sociais básicos e a minimização do desemprego; em que o ideário socialista fosse propagado por uma estrutura de educação, de meios de comunicação social e do partido único (Behring, 2003). 
Para essa realidade, vive-se o desmonte da cidadania social, uma das maiores conquistas democráticas e o abalo da utopia de construção de uma sociedade livre de incertezas e desamparos sociais (Estado de Bem-Estar Social).

Como afirma Pereira (2000a, p.56), tem-se em quase todo o mundo, o desmonte das políticas nacionais de garantias sociais básicas, cujas principais implicações estão voltadas aos cortes de programas sociais à população de baixa renda, à diminuição dos benefícios da seguridade social e à criminalização da pobreza com o incentivo às práticas tradicionais de clientelismo, à filantropia social e empresarial, à solidariedade informal e ao assistencialismo, revestidos de práticas alternativas e inovadoras para uma realidade de pobreza e exclusão social. ${ }^{9}$

No que diz respeito ao Estado Capitalista, este sempre assumiu historicamente os interesses da burguesia, da classe dominante assegurando muitos favorecimentos e benefícios para a primazia do lucro. Afirma Netto (1996, p.100) que "[...] a desqualificação do Estado tem sido, como se sabe, a pedra-de-toque do privatismo da ideologia neoliberal: a defesa do 'Estado Mínimo' pretende fundamentalmente o 'Estado Máximo' para o Capital”.

O enfrentamento do Estado Nacional mediante as exigências da globalização capitalista, em transferir as responsabilidades e as decisões do mesmo para o mercado, o bem comum dos cidadãos para a iniciativa privada, a soberania da nação para a ordem social capitalista dominante no cenário mundial (Abreu, 2000, p.41) vêm acompanhados de desregulamentação e de extinção de direitos sociais, mas com uma "proposta" de modernização, liberdade, democracia e cidadania.

9 Exclusão Social é aqui entendida como uma situação de privação coletiva que inclui pobreza, discriminação, subalternidade, a não equidade, a não acessibilidade, a não representação pública como situações multiformes. Expressas entre outras situações como: o crescimento da população nas ruas, nas cidades nos abrigos, os sem-teto, o crescimento da violência, o desemprego de longa duração, a fragilização das estruturas familiares, o crescimento do uso indevido de drogas, a mudança do sistema produtivo entre outros (Sposati, 1999, p.67-8). 
Os rebatimentos do neoliberalismo (ideologia capitalista) nas políticas sociais são desastrosos. Estas passam a ter um caráter eventual e complementar por meio de práticas fragmentadas e compensatórias, como afirma Laurell (1997, p.163):

o Estado só deve intervir com o intuito de garantir um mínimo para aliviar a pobreza e produzir serviços que os privados não podem ou não querem produzir, além daqueles que são, a rigor, de apropriação coletiva. Propõem uma política de beneficência pública ou assistencialista com um forte grau de imposição governamental sobre que programas instrumentar e quem instruir, para evitar que se gerem "direitos". Além disso, para se ter acesso aos benefícios dos programas públicos, deve-se comprovar a condição de indigência. Rechaça-se o conceito dos direitos sociais e a obrigação da sociedade de garanti-los através da ação estatal. Portanto, o neoliberalismo opõe-se radicalmente à universalidade, igualdade e gratuidade dos serviços sociais.

O cumprimento do ideário neoliberal pelos diversos países terá influência sobretudo por sua tradição histórica e cultural, pelo regime político vigente inserido no mundo globalizado, bem como pelo enfrentamento da questão social (que será abordado no último item deste capítulo) e pelo nível de organização da classe trabalhadora.

Não será aprofundada essa questão, senão apresentada a implementação das políticas sociais no Brasil destinadas a minimizar a questão social que, nas primeiras décadas do século XX, foi tratada como questão de polícia.

As políticas sociais brasileiras estão diretamente relacionadas às condições vivenciadas pelo País em níveis econômico, político e social. Estão, portanto, no centro do embate econômico e político deste início de século, pois a inserção do Brasil (país periférico do mundo capitalista) no mundo globalizado, far-lo-á dependente das determinações e decisões do capital e das potências mundiais hegemônicas.

Para entender o real significado das políticas sociais, deve-se relacioná-las estreitamente a suas funções, que, segundo Pastorini 
(1997, p.85), partindo da perspectiva marxista, as políticas sociais devem ser entendidas como produto concreto do desenvolvimento capitalista, de suas contradições, da acumulação crescente do capital e, assim, um produto histórico, e não consequência de um desenvolvimento "natural". As políticas sociais desenvolvem algumas funções primordiais no mundo capitalista: função social, econômica e política (Pastorini, 2006, p.84-92).

A começar pela função social, afirma-se que as políticas sociais têm por objetivo o atendimento redistributivo dos recursos sociais, por meio de serviço sociais e assistenciais, para um complemento salarial às populações carentes. Contudo, esta função dissimula as verdadeiras funções que as políticas sociais desempenham no mundo capitalista ao apresentarem-se como mecanismos institucionais que compõem uma rede de solidariedade social que objetiva diminuir as desigualdades sociais, oferecendo mais serviços sociais àqueles que têm menos recursos (Pastorini, 1997, p.88).

Neste sentido, como analisa Iamamoto (2002, p.97-8), são devolvidos aos usuários os serviços sociais de direito: saúde, educação, política salarial, trabalho, habitação, lazer e outros, como benesse, assistência, filantropia, favor, ou seja, medidas parcelares e setoriais que o Estado oferece nas questões sociais para manter o controle e a ordem social. Essa ação paternalista do Estado tende a inibir crises sociais e legitimam seu discurso demagógico de cooperação entre as classes sociais e o ajustamento da classe trabalhadora às regras do modelo neoliberal.

Do ponto de vista da classe trabalhadora, estes serviços podem ser encarados como complementares, mas necessários à sua sobrevivência, diante de uma política salarial que mantém aquém das necessidades mínimas historicamente estabelecidas para a reprodução de suas condições de vida. São ainda vitais, mas não suficientes, para aquelas parcelas da força de trabalho alijadas momentaneamente do mercado de trabalho ou lançadas no pauperismo absoluto. Porém, à medida que a gestão de tais serviços escapa inteiramente ao controle dos trabalhadores, não lhes sendo facultado opinar e intervir no rumo 
das políticas sociais, as respostas às suas necessidades de sobrevivência tendem a ser utilizadas como meio de subordinação dessa população aos padrões vigentes [...] Do ponto de vista do capital, tais serviços constituem meios de socializar os custos de reprodução da força de trabalho, preferível à elevação do salário real, que afeta diretamente a lucratividade da classe capitalista [...] A filantropia é redefinida na perspectiva da classe capitalista: a "ajuda" passa a ser concebida como investimento. Não se trata de "distribuir" mas de "construir", de favorecer a acumulação do capital. É esta a lógica que preside a organização dos serviços sociais.

Ficam portanto, evidentes, a partir da autora, as funções das políticas sociais (e públicas) que são: econômica, política e social.

No que diz respeito à função econômica, tem-se a ação do Estado por meio da transferência direta ou indireta (pagos pela população por meio de impostos) de bens, recursos e outros, aos usuários mais carentes da população, oferecidos em forma de prestação de serviços sociais como a saúde, a educação e a assistência social, visando ao "barateamento da força de trabalho e consequente acumulação ampliada do capital” (Pastorini, 2006, p.87). Essas ações apresentam-se como formas compensatórias às quedas do salário real, desobrigando o capitalista a atender exclusivamente as necessidades de sobrevivência e reprodução da força de trabalho. Com isso, no contexto atual, parte desses custos são retirados das empresas e designadas ao Estado que possui a tarefa de suprir as necessidades básicas da classe trabalhadora, por meio das políticas sociais (idem, p.88).

Deve-se reconhecer, então que o Estado assume o papel de anticrise por meio das políticas sociais, que contribuem para a subordinação do trabalho ao capital, com a força da mão de obra ocupada e excedente e também pela adequação e controle da população trabalhadora que pode ter condições de consumo contra a tendência nefasta do subconsumo. Como afirma Netto (1996a, p.26-7):

Através da política social, o Estado burguês no capitalismo monopolista procura administrar as expressões da "questão social" de 
forma a atender às demandas da ordem monopólica conformando, pela adesão que recebe de categorias e setores cujas demandas incorpora, sistemas de consenso variáveis, mas operantes [...] a funcionalidade essencial da política social do Estado burguês no capitalismo monopolista se expressa nos processos referentes à preservação e ao controle da força de trabalho ocupada, mediante a regulamentação das relações capitalistas/trabalhadoras [...].

Neste sentido, as políticas sociais apresentam-se como estratégias governamentais de integração da força de trabalho na relação de trabalho assalariado, destinadas a atender problemáticas particulares e específicas apresentadas pela questão social (produto e condição da ordem burguesa), contribuindo para uma subordinação dos trabalhadores ao sistema vigente e reproduzindo as desigualdades sociais decorrentes das diferentes participações no processo de produção (Pastorini, 1997, p.90).

Por fim, a função política das políticas sociais diz respeito ao contexto de lutas entre as classes sociais opostas, não podendo ser vistas como meros favores das classes dominantes para os dominados, nem como conquista das reivindicações e pressões populares. Na concepção geral de Estado, ${ }^{10}$ tem-se interesses e disputas das classes, não sendo exclusivamente instrumento da classe dominante. Com isso, as políticas sociais apresentam-se como expressão da correlação de forças e lutas na sociedade civil, e concessões dos grupos majoritários no poder objetivando obter legitimidade e controle social (Pastorini, 2006, p.89).

Segundo Faleiros (1991, p.45 e 80), as políticas sociais devem ser entendidas como produto histórico concreto a partir do contexto da estrutura capitalista; com isso:

As políticas sociais são formas de manutenção da força de trabalho econômica e politicamente articuladas para não afetar o processo

10 O Estado é a ordem jurídica e política que regula um sistema de dominação: do homem pelo homem, segundo Weber e de uma classe por outra, segundo Marx \& Engels. 
de exploração capitalista e dentro do processo de hegemonia e contrahegemonia da luta de classes. [...] as políticas sociais, apesar de aparecerem como compensações isoladas para cada caso, constituem um sistema político de mediações que visam à articulação de diferentes formas de reprodução das relações de exploração e dominação da força de trabalho entre si, com o processo de acumulação e com as forças políticas em presença.

Mediante esse breve entendimento das funções das políticas sociais há que se considerar que estas não podem ser entendidas como um movimento linear e unilateral, ou seja, do Estado para a sociedade civil como concessão ou da sociedade civil para o Estado como luta e conquista, contudo têm de ser analisadas como um processo dialético entre as classes sociais, como afirma Pastorini (1997, p.97).

As políticas sociais no Brasil tiveram, nos anos 80 , formulações mais impactantes na vida dos trabalhadores e ganharam mais impulso, após o processo de transição política desenvolvido em uma conjuntura de agravamento das questões sociais e escassez de recursos. Não obstante, as políticas sociais brasileiras sempre tiveram um caráter assistencialista, paternalista e clientelista, com o qual o Estado, por meio de medidas paliativas e fragmentadas, intervém nas manifestações da questão social, preocupado, inicialmente, em manter a ordem social. São elas formatadas a partir de um contexto autoritário no interior de um modelo de crescimento econômico concentrador de renda e socialmente excludente. Assim afirma Vieira, E. (1997, p.68):

A política social brasileira compõe-se e recompõe-se, conservando em sua execução o caráter fragmentário, setorial e emergencial, sempre sustentada pela imperiosa necessidade de dar legitimidade aos governos que buscam bases sociais para manter-se e aceitam seletivamente as reivindicações e até as pressões da sociedade.

Nos anos 80, o País viveu o protagonismo dos movimentos sociais que contribuiu com uma série de avanços na legislação brasileira no que diz respeito aos direitos sociais. 
A Constituição Federal, promulgada em 1988, chamada Constituição Cidadã, pauta-se em parâmetros de equidade e direitos sociais universais. Consolidou conquistas, ampliou os direitos nos campos da Educação, da Saúde, da Assistência, da Previdência Social, do Trabalho, do Lazer, da Maternidade, da Infância, da Segurança, definindo especificamente direitos dos trabalhadores urbanos e rurais, da associação profissional e sindical, de greve, da participação de trabalhadores e empregadores em colegiados dos órgãos públicos, da atuação de representante dos trabalhadores no entendimento direto com empregadores (artigos 6 a 11, do Capítulo II, do Título II - Dos Direitos e Garantias Fundamentais).

Assim, pela primeira vez na história brasileira, a política social teve grande acolhimento em uma Constituição. Entretanto, duas décadas depois pode-se afirmar que nunca houve tantos desrespeitos à sociedade brasileira, como hoje, por meio de violações, fraudes e corrupções explícitas do Estado, da classe hegemônica, dos representantes do poder e do povo, na legislação vigente, nos repasses dos recursos financeiros, nas relações de trabalho, com um mercado altamente seletivo e excludente e outros. E com Vieira, E. (1997, p.68), pode-se afirmar que se tem no Brasil uma "política social sem direitos".

Como exemplo nacional, algumas leis complementares foram regulamentadas a partir da proposta constitucional de $1988,{ }^{11}$ como a Lei n. 8.069 de 1990 - o Estatuto da Criança e do Adolescente - a Lei n. 8742 de 1993 - Lei Orgânica da Assistência Social - resultantes de uma ampla mobilização dos segmentos da sociedade representantes de diversas categorias sustentados pelo paradigma da cidadania que, segundo Boff (2000, p.51), entende-se por cidadania

o processo histórico-social que capacita a massa humana a forjar condições de consciência, de organização e de elaboração de um

11 Não se trata aqui de realizar um estudo detalhado de tais leis, mas ressaltar sua importância no cenário nacional e ainda que outras leis complementares foram conquistadas nas décadas posteriores, como a Lei n. 10.741 de 2003 e outras. 
projeto e de práticas no sentido de deixar de ser massa e de passar a ser povo, como sujeito histórico plasmador de seu próprio destino. O grande desafio histórico é certamente este: como fazer das massas anônimas, deserdadas e manipuláveis um povo brasileiro de cidadãos conscientes e organizados. É o propósito da cidadania como processo político-social e cultural.

Na realidade vigente, o desrespeito às leis complementares da Constituição tem sido a tônica de vários governos, consequentemente temos o descaso com a população trabalhadora e assim as políticas sociais continuam assistencialistas e mantêm a população pobre, grande parte miserável, excluída do direito à cidadania, dependente dos benefícios públicos, desmobilizando, cooptando e controlando os movimentos sociais.

O que se pode constatar diante do exposto, é que a efetivação de políticas sociais (públicas ou privadas) reflete a realidade marcante de um país dependente e está condicionada ao modelo neoliberal, que prevê que cada indivíduo garanta seu bem-estar em vez da garantia do Estado de direito.

Outro aspecto a destacar é que os avanços da legislação não podem negar seus limites. O fundamento das desigualdades sociais está alicerçado na forma de produção da riqueza que, na sociedade capitalista, se sustenta sobre a propriedade privada dos meios de produção e nas contradições de classe. Diante disso, o homem torna-se sujeito coletivo e transformador das relações existentes. Então, a busca pela transformação social é um processo que necessita do fortalecimento da população e de protagonistas na conquista de direitos, na participação, que segundo Marx (1982, p.1985), "a história dos homens é a história de suas relações sociais, e capitalismo é expressão da luta de classe entre burguesia e proletariado".

Cabe aos sujeitos sociais a construção e a transformação das relações sociais. São diversos os segmentos presentes nesta luta, especialmente os profissionais, assistentes sociais, que têm o compromisso de mediar as relações entre Estado, trabalhadores e Capital e gerir as políticas sociais. Neste início de milênio, o cenário colocado pelo capi- 
talismo em seu modelo neoliberal, coloca para o Brasil questões agravantes como alto índice de desempenho, aumento da concentração de renda/riqueza, empobrecimento e miserabilidade da população.

E, nessa dinamicidade da história, o novo milênio traz em seu bojo o desejo de um novo projeto societário com referência a conquista dos direitos da cidadania. Daí o redimensionamento das políticas sociais que poderão sinalizar uma distribuição de renda equitativa. Tal realidade tem um impacto direto na atuação do Serviço Social que atua na elaboração, na organização e na gestão das políticas sociais, tema do próximo item.

\section{Organização e gestão das políticas sociais}

Conforme discutido anteriormente, as políticas sociais no Brasil emergem no final da República Velha, especialmente nos anos 20 (séc.XX), e começam a conquistar espaço no período getulista. Contudo, até a Constituição Federal de 1988, o País não tinha um aparato jurídico-político que apontasse para a formação mínima de padrões de um Estado de Bem-Estar Social. Na década de 1980, foram reorganizadas as políticas sociais contra a ditadura militar e têm sido, nos últimos anos, ocasião de debates no contexto das lutas pela democratização do Estado e da sociedade no Brasil. Novos interlocutores e sujeitos sociais surgiram no campo das políticas sociais por meio da participação de segmentos organizados da sociedade civil na formulação, implementação, gestão e controle social destas políticas.

Esse fenômeno ocorre a partir da crise dos anos 80 (séc. XX), que se depara com realidades determinantes de ordem política, vinculada à crise da ditadura e à transição marcada pela democratização do Brasil, e de ordem econômica e social, decorrentes do processo de reorganização mundial do capitalismo. Situação essa consequente da crise do chamado Estado de Bem-Estar Social, em meados da década de 1970 e da derrocada do Leste Europeu, nos anos 80, que se abriram às propostas neoliberais, findando as concepções do Estado, enquanto instância mediadora da universalização dos direitos sociais. 
Neste cenário de redefinições das relações entre Estado e sociedade civil, acontecem muitas mobilizações de grupos e protagonistas sociais por meio de debates e propostas no enfrentamento da crise social, que desencadearam no processo constituinte resultando na reforma Constitucional em 1988.

Neste contexto da chamada década perdida de 1980, em função da crise da ditadura, do agravamento da questão social, do aumento da pobreza e da miséria e da luta pela democratização do País, Estado e sociedade, intensificam-se as discussões sobre as políticas sociais de caráter público. É importante ressaltar que, embora seja um período intenso das desigualdades sociais, também é marcado dialeticamente por conquistas democráticas sem precedentes na história política brasileira.

As políticas sociais no período de 1964 a 1988, eram políticas de controle, seletivas, fragmentadas, excludentes e setorizadas. Daí a necessidade de questionar esse padrão histórico das políticas sociais e propor a democratização dos processos decisórios na definição de prioridades, na elaboração, execução e gestão dessas políticas. Nesse sentido, a elaboração e a conquista das políticas sociais passam ainda por processos de pressões e negociações entre as forças políticas vigentes e uma relativa transparência das articulações (Faleiros, 1991, p.70).

Nessa dinâmica, travou-se, a partir de 1985, com a Assembleia Constituinte, uma luta na sociedade em torno da definição de novos procedimentos e de regras políticas que regulassem as relações do Estado com a sociedade civil, objetivando criar um novo posicionamento democrático.

Dados históricos, segundo Raichelis (2000, p.62), revelam intensa participação da sociedade brasileira

em função da Assembleia Constituinte, reuniram-se na Articulação Nacional de Entidades pela Mobilização Popular na Constituinte, cerca de 80 organizações, algumas de âmbito nacional, compostas por associações, sindicatos, movimentos sociais, partidos, comitês plenárias populares, fóruns, instituições governamentais e privadas, 
que se engajaram num amplo movimento social de participação política que conferiu visibilidade social a propostas de democratização e ampliação de direitos em todos os campos da vida social.

No cenário das relações entre Estado e sociedade civil, surgiram neste período novos espaços em que forças sociais foram protagonistas na formulação de projetos societários para o enfrentamento da crise social que assolou o Brasil nos anos 80 e a disseminação da pobreza e da miséria, que colocou o País em alto nível de desigualdade social.

A Constituição Federal de 1988 definiu instrumentos de participação da sociedade civil no controle da gestão das políticas sociais, estabeleceu mecanismos de participação e implementação destas políticas, apontou canais para o exercício da democracia participativa, por meio de decisões direta como o plebiscito, referendo e de projetos de iniciativa popular. Nesta perspectiva, a Carta Constitucional instituiu a criação de conselhos integrados por representantes dos diversos segmentos da sociedade civil para colaborar na implementação, execução e controle das políticas sociais.

Hoje, esses conselhos, que expressam uma das principais inovações democráticas no campo das políticas sociais, organizam-se em diferentes setores destas políticas e assumem uma representatividade nas diferentes esferas governamentais. Possuem uma composição paritária entre representantes da sociedade civil e do governo e função deliberativa no que se refere à definição da política em cada setor e ao controle social sobre sua execução.

Por meio dessa concepção dinâmica da sociedade, é possível acreditar que os espaços de representação social na organização e gestão das políticas sociais devem ser ampliados, buscando a participação de novos e diferentes sujeitos sociais, especialmente, os tradicionalmente excluídos do acesso às decisões do poder político.

Várias são as experiências hoje, de organização dos conselhos, nas áreas da saúde, da criança e do adolescente, da educação, da assistência social e de outras; são novas formas de participação da sociedade civil na esfera pública com uma proposta de democrati- 
zação das políticas sociais, porém muitas vezes na contraposição do modelo neoliberal legitimado pelos governos vigentes.

Para Raichelis (2000, p.63):

O termo público-estatal (publicização) tem despertado uma polêmica político-ideológica pela apropriação do seu significado, que remete ao caráter das relações entre o Estado e sociedade na constituição da chamada esfera pública [...] é adotado numa visão ampliada de democracia, tanto do Estado quanto da sociedade civil, e na implementação de novos mecanismos e formas de atuação, dentro e fora do Estado, que dinamizem a participação social para que ela seja cada vez mais representativa da sociedade, especialmente das classes dominadas.

Neste sentido, busca-se romper com a subordinação histórica da sociedade civil frente ao Estado, por meio da construção de espaços de discussão e participação da sociedade civil na dimensão política da esfera pública, rumo à universalização dos direitos de cidadania.

A conquista de novos espaços de participação da sociedade civil consolidou-se na construção de descentralização das ações, com maior responsabilidade dos municípios na formulação e na implantação de políticas sociais, na transferência de parcelas de poder do Estado para a sociedade civil organizada. Os conselhos paritários e deliberativos no âmbito das políticas públicas foram a estratégia privilegiada. Ou seja, são compostos por representantes de entidades da sociedade civil e representantes do governo que devem, em conjunto, participar do planejamento, das decisões e do controle de políticas sociais setoriais. Os conselhos são espaços públicos de discussão, decisão, acompanhamento e fiscalização de ações, programas e distribuição de recursos. E para Raichelis (2000, p.66), os conselhos são "expressões de novas relações políticas entre governos e cidadãos e um processo de interlocução permanente:

Os conselhos significam o desenho de uma nova institucionalidade nas ações públicas, que envolvem distintos sujeitos nos âmbitos 
estatal e societal. A constituição de tais espaços, tornou-se possível, também, em virtude das mudanças que se processavam nos movimentos populares que, de costas para o Estado no contexto da ditadura, redefiniram estratégias e práticas, passando a considerar a participação institucional como espaço a ser ocupado pela representação popular.

Por meio dos conselhos, objetiva-se propor alternativas de políticas públicas, criar espaços de debates entre governos e cidadãos, buscar mecanismos de negociação, conhecer a lógica burocrática estatal para socializar as ações e deliberações, ultrapassar interesses particulares e corporativistas em atendimento às demandas populares. Tem-se uma realidade dinâmica que busca a construção de esferas públicas autônomas e democráticas em relação às decisões políticas e assim, rever as relações entre espaço institucional e práticas societárias.

Hoje, têm-se nos municípios brasileiros um grande número de conselhos implementados em diferentes setores, o que revela um novo modelo de participação da sociedade na gestão pública, oriundo das lutas sociais das últimas décadas, que propõem uma redefinição das relações entre espaço institucional e práticas societárias, como forças antagônicas e conflitantes que se completam na busca de uma sociedade democrática.

É evidente que a garantia legal da criação e da implementação desses conselhos, não garante a efetivação e a operacionalização de todos, assim como a participação popular não pode tão pouco ser reduzida apenas ao espaço dos conselhos, sejam eles de assistência social, criança e adolescente, educação, saúde e outros. Tal participação apresenta-se como forma de participação política da sociedade civil organizada e que precisa ser devidamente acompanhada e avaliada. Com um acompanhamento sistemático das práticas dos conselhos, nas diferentes políticas sociais e nos diversos níveis governamentais, sinaliza para o perigo da burocratização, da rotina e da cooptação pelos órgãos públicos, centralizando as decisões nas mãos do poder governamental, neutralizando ou fragilizando a autonomia dos conselhos em suas ações e decisões. 
Tem-se na realidade dos muitos municípios brasileiros essa interferência dos órgãos governamentais principalmente no que diz respeito às decisões relativas ao orçamento, processo eleitoral dos conselheiros, a escolha das presidências e outros.

Apresenta-se como desafio, então, a formação dos conselheiros, sobretudo da sociedade civil, nas competências políticas, econômicas, éticas, sociais, e outras, para o exercício de seu papel com seriedade e compromisso social na gestão pública.

Diante disso, o profissional de Serviço Social tem se inserido com frequência nos conselhos em suas diferentes áreas. Se por um lado sua contribuição tem feito avançar a esfera pública no campo das políticas sociais, por outro, tem-se apresentado à profissão a urgência da qualificação em seu aspecto teórico-prático e ético-político, para atuar na elaboração dos planos nas esferas governamentais.

No que diz respeito à participação e à descentralização ${ }^{12}$ políticoadministrativa no campo das políticas sociais, essas estratégias revelam um recente processo de redemocratização vivenciado no Brasil, para integrar a relação entre Estado e sociedade. Conforme afirma Stein (1997, p.75):

A descentralização adquiriu um ar de modernidade e recentemente constituiu palavra de ordem no mundo político e administrativo, especialmente no Brasil, a partir do processo constituinte de 1987. Dentre os princípios enumerados pela nova Constituição de 1988, o da descentralização política-administrativa demarca uma nova ordem política na sociedade, a partir do momento que à sociedade é garantido o direito de formular e controlar políticas, provocando um redirecionamento nas tradicionais relações entre Estado e sociedade.

A descentralização implica transferência de poderes, atribuições e competências, baseia-se em uma divisão de trabalho social entre

12 Não se tem a pretensão de discutir sobre o processo de centralização-descentralização previsto na Constituição Federal, apenas reforçar a importância na redefinição de papéis normativos, reguladores e redistributivos nas responsabilidades dos Estados e Municípios. 
a União, o Estado e o Município, onde este responde pela formulação, organização e implementação das ações, sem abrir mão do apoio técnico-financeiro dos níveis supramunicipais de governo, de acordo com o que determina a Constituição Federal. O processo de descentralização pressupõe a existência da democracia, da autonomia e da participação, entendidas como medidas políticas que passam pela redefinição das relações de poder, como componentes essenciais do desenvolvimento de políticas sociais voltadas às necessidades humanas e à garantia de direitos dos cidadãos.

Contudo, o que se sabe nacionalmente, é que os princípios proclamados não alcançaram o plano das intenções, ou seja, não existiu uma verdadeira política nacional de descentralização que orientasse a reforma das diferentes políticas sociais, salvo a área da saúde, como tem sido destaque em sua reforma que resultou em uma política deliberada e radical de descentralização, não obstante, com resultados positivos comprometidos, tendo em vista as dificuldades de relacionamento entre as diferentes esferas de governo e o setor privado prestador de serviço, por meio dos graves problemas de financiamento (Silva, 1995, p.23). Outros fatores, como: a ausência de redistribuição de competências e atribuições, a crise fiscal (crise do capitalismo) associada às indefinições do governo federal, interesses particulares em manter uma estrutura de centralização, ausência de um programa nacional planejado de descentralização na consecução e articulação de programas e projetos nas políticas sociais contribuíram para a não efetivação desta proposta constitucional.

Com essa realidade acima apresentada, vê-se que as estratégias de implementação das políticas sociais são várias. Vão desde um Estado provedor de bens e serviços até um Estado que responsabiliza a sociedade civil, por meio de suas redes de filantropia e solidariedade, no enfrentamento das expressões das questões sociais e colocando-a diante do desafio de discutir e decidir a importância da descentralização e participação como estratégia de democratização das relações de poder e de acesso a bens e serviços públicos (Stein, 2000, p.83).

Diante disso, a formulação, o acesso e a qualidade das políticas sociais é tarefa difícil, pois pressupõe a existência de recursos 
financeiros e financiamentos suficientes para atender às demandas da população e às responsabilidades do poder público, bem como a gestão financeira de instrumentos que assegurem a democratização e a transparência na concepção das políticas sociais.

Hoje, a União arrecada impostos sobre renda, produtos industrializados, importação, exportação, operações financeiras, contribuições sociais e outros, sendo parte transferidos para os fundos de participação dos Estados e dos Municípios, ${ }^{13}$ que, por sua vez, possuem também suas arrecadações próprias, segundo a legislação.

No que tange às políticas sociais, a Constituição Federal, em seu artigo 194, traz inovações, dentre elas o conceito de seguridade social, ${ }^{14}$ com orçamento próprio para cada área (previdência social, saúde e assistência social) e com recursos diferenciados dos que financiariam as demais políticas sociais.

Segundo Behring \& Boschetti (2006, p.165):

Os recursos permanecem extremamente concentrados e centralizados, contrariando a orientação constitucional da descentralização. Além de concentrados na União - o ente federativo com maior capacidade de tributação e de financiamento -, também há concentração na alocação dos recursos nos serviços da dívida pública, juros, encargos e amortizações, rubrica com destinação sempre maior que todo o recurso da seguridade social - e para as políticas sociais que são financiadas pelo orçamento fiscal, a exemplo da educação, reforma agrária e outras, as quais não estão contempladas no conceito constitucional restrito de seguridade social do Brasil.

Entretanto, mesmo diante do aumento da arrecadação tributária, não tem ocorrido aumento de recursos para as políticas sociais de

13 Ressalta-se aqui somente a realidade de que existem impostos e contribuições sociais cobrados pela União, sem pretensão de aprofundamento, que para isso é necessário consultar a Constituição Federal de 1988, em seu Capítulo I (Do Sistema Tributário Nacional) do Título VI.

14 Art. 194. A seguridade social compreende um conjunto integrado de ações de iniciativas dos Poderes Públicos e da sociedade, destinadas a assegurar os direitos relativos à saúde, à previdência e à assistência social. 
modo geral e especialmente para a seguridade social, que tem sofrido desvios de recursos nos últimos anos e que, por meio desses recursos, poderiam ampliar os direitos relativos às políticas de previdência, à saúde e à assistência social.

Embora com alguns avanços observados no financiamento das políticas sociais, com a busca da democratização da gestão financeira, a implementação de fundos especiais e de participação popular, aprofundamento do processo de descentralização de recursos com relação ao montante transferido, novas formas de repasse e outros, não são suficientes para atender às demandas da população. E o que se tem é o aumento da miséria, da fila dos desempregados, dos excluídos e de outros.

Conforme afirmam Behring \& Boschetti (idem, p.172):

A sustentação financeira com possibilidade de ampliação e universalização dos direitos, assim, não será alcançada com ajustes fiscais que expropriam recursos das políticas sociais. A consolidação da seguridade social brasileira, e da política social brasileira de uma forma geral, já que essa direção atinge também políticas que estão dentro do orçamento fiscal, depende da reestruturação do modelo econômico, com investimentos no crescimento da economia, geração de empregos estáveis com carteira de trabalho, fortalecimento das relações formais de trabalho, redução do desemprego, forte combate à precarização, transformação das relações de trabalho flexibilizadas em relações de trabalho estáveis, o que, consequentemente, produzirá ampliação de contribuições e das receitas da seguridade social e, sobretudo, acesso aos direitos sociais.

Diante de tudo o que foi exposto, o que se percebe é que as políticas sociais são definidas e operacionalizadas a partir das reformas de cunho neoliberal e legitimadas pelas agências internacionais; o projeto neoliberal privilegia a defesa das privatizações e a constituição do cidadão consumidor.

Nessa realidade de defesas de privatizações, é sentido um impacto direto, por exemplo, na seguridade social e, assim, as políticas 
referentes à infância, à juventude e à família revelam o aspecto da mercantilização da saúde e da previdência social, dificultando o acesso universal a esses sujeitos sociais e a proteção de direitos do adolescente trabalhador. Também na assistência social, observa-se a ampliação do assistencialismo, de programas focalizados, a ênfase nas parcerias com a sociedade civil e a família, atribuindo a elas ações de responsabilidade do Estado; e ainda a desconsideração da assistência social como política pública.

Assim, as políticas sociais devem ser defendidas como instrumento estratégico das classes subalternas na garantia de condições sociais de vida aos trabalhadores para sua emancipação humana e a luta organizada para a conquista da emancipação política. Com isso, a busca da ampliação dos direitos e das políticas sociais é essencial, porque envolve milhões de brasileiros espoliados em qualidade de vida, dignidade humana, condições de trabalho. O profissional assistente social é chamado, então, a atuar nas expressões da questão social, formulando, implementando e viabilizando direitos sociais, por meio das políticas sociais, como será abordado no próximo item.

\section{A questão social e desafios para a implementação de políticas sociais de direito}

No que diz respeito à questão social, a presente reflexão parte do princípio relacional da questão social com o modo de produção capitalista, no bojo do processo de industrialização e do surgimento do proletariado e da burguesia industrial. Historicamente, a "questão social" é nominação surgida na segunda metade do século XIX, na Europa ocidental, a partir das manifestações de miséria e de pobreza oriundas da exploração das sociedades capitalistas com o desenvolvimento da industrialização. É neste contexto que iniciam as respostas para o enfrentamento desse novo jeito do capitalismo surgido naquela época.

Segundo Cerqueira Filho (1982, p.21): 
Por questão social, no sentido universal do termo, queremos significar o conjunto de problemas políticos, sociais e econômicos que o surgimento da classe operária provocou na constituição da sociedade capitalista. Logo, a questão social está fundamentalmente vinculada ao conflito entre capital e trabalho.

No capitalismo concorrencial, a questão social era tratada de forma repressiva pelo Estado, ou seja, a organização e a mobilização da classe operária para a conquista de seus direitos sociais, eram casos de polícia.

Já no início do século XX, com o contexto de emergência do capitalismo monopolista, a questão social torna-se objeto de resposta e de estratégia do Estado, por meio de políticas sociais como mecanismo básico de controle das classes trabalhadoras e, ao mesmo tempo, legitima-se como representativo de toda a sociedade. Passa a exigir intervenção dos poderes públicos nas questões trabalhistas e a criação de órgãos públicos que pudessem se ocupar dessas questões.

São criados no Brasil novos aparelhos e instrumentos de controle como o Ministério do Trabalho e a Consolidação das Leis Trabalhistas (CLT) que objetivavam mais a desmobilização e despolitização da classe operária emergente do que a eliminação de conflitos.

Pensar a questão social na contemporaneidade é um desafio, pois esta é reproduzida pela mundialização da economia e pelo retorno forçado do mercado autorregulado. Esses fatores intensificam-se pela competição e pela concorrência nos Estados por meio de pressões internas e entre os Estados pela intensidade das pressões externas e pela capacidade de proteção e direitos contra o mercado. No Brasil, isso não ocorre, pois as proteções de trabalho não possuem raízes de sustentação e sucumbem rapidamente (Arcoverde, 2000, p.77).

No Brasil hoje, a questão social apresenta-se de forma grave, porque atinge intensamente todos os setores e classes sociais, sendo constantemente ameaçada pelo pauperismo do século XX e pelos excluídos do século XXI e, dessa forma, a realidade vigente de uma política salarial injusta dificulta a construção de uma sociedade coesa e articulada por meio de relações democráticas e interdependentes. 
O que se tem no País é uma desmontagem do sistema de proteção e garantias do emprego e, consequentemente, uma desestabilização e uma desordem do trabalho que atingem todas as áreas da vida social.

Como afirma Arcoverde (idem, p.79), a questão social brasileira assumiu variadas formas, tendo como características orgânicas a desigualdade e a injustiça social ligadas à organização do trabalho e à cidadania. Resultante da "estrutura social produzida pelo modo de produção e reprodução vigentes e pelos modelos de desenvolvimento que o País experimentou: escravista, industrial (desenvolvimentista), fordista - taylorista e o de reorganização produtiva".

Assim, as expressões da questão social, tais como: as desigualdades e as injustiças sociais são consequentes das relações de produção e reprodução social por meio de uma concentração de poder e de riqueza de algumas classes e setores dominantes, que geram a pobreza das classes subalternas. E tornam-se questão social quando reconhecidas e enfrentadas por setores da sociedade com o objetivo de transformação em demanda política e em responsabilidade pública.

Com tudo isso, tem-se que a questão social, que deve ser enfrentada enquanto expressão das desigualdades da sociedade capitalista brasileira, é construída na organização da sociedade e manifesta-se no espaço societário onde se encontram a nação, o Estado, a cidadania, o trabalho.

Como afirma Iamamoto (2001, p.28) "o Serviço Social tem como tarefa decifrar as formas e expressões da questão social na contemporaneidade e atribuir transparência às iniciativas voltadas à sua reversão ou enfrentamento imediato".

Dessa forma, é indispensável decifrar as novas mediações, por meio das quais se expressa a questão social hoje, ou seja, é importante que se possam apreender as várias expressões que assumem na atualidade as desigualdades sociais e projetar formas de resistência e de defesa da vida (Iamamoto, 2004, p.268).

Continuam questionamentos para o Serviço Social, suas possibilidades e seus limites, frente aos desafios do mundo contemporâneo. A busca da implementação de políticas de direito sinaliza como grande 
desafio ao profissional assistente social que luta pelo protagonismo das classes subalternizadas.

A década de 1980, no Brasil, pôde ser marcada pela busca da democracia, pela organização e pela mobilização de diversos segmentos da sociedade civil e pela luta por direitos sociais, políticos e civis contra governos ditadores.

Após a declaração constitucional em 1988, do direito à participação popular e à descentralização político-administrativa, foram ampliados os espaços públicos, por meio de experiências da sociedade civil em conselhos comunitários, conselhos deliberativos das políticas sociais, associações, sindicatos. Segmentos da sociedade civil reivindicaram inovações de práticas políticas do País ao exigir o direito à participação na gestão das políticas públicas. $\mathrm{O}$ cidadão passa a entender que possui direitos e reivindica por sua efetividade.

A democracia passou a conviver com o ajuste estrutural da economia e com as limitações dos gastos públicos, além da necessidade de preparo dos conselheiros e dos gestores para a prática da gestão democrática e participativa. Embora o pacto federativo previsse a corresponsabilidade do poder nas esferas governamentais, União, Estados e Municípios, este último tornou-se um ente federado, fortalecendo o processo de municipalização das políticas sociais e passou a ser o principal responsável pela oferta dos serviços sociais, como a saúde, a educação, a assistência social, ampliando a complexidade da gestão das políticas sociais em nível local.

Com isso, o município criou vários mecanismos para efetivar as determinações constitucionais no que diz respeito à participação e à gestão das políticas sociais. Surgiram os Conselhos de Políticas Públicas na área da criança e do adolescente, do idoso, da assistência social, da educação, da saúde e de outros. Entretanto os Conselhos necessitam ainda aprender a ser deliberativos, pois essa democracia participativa enfrenta o desafio histórico de uma "cultura" clientelista e autoritária, pautada no mando e não no direito.

As políticas sociais podem ser "mecanismos eficientes para a democratização do acesso a bens e serviços para a população e também 
atuam como condições necessárias ao desenvolvimento econômico e social" (Costa, 2006, p.68).

Dessa forma, propor a construção da igualdade social no Brasil, visando à conquista da cidadania, exige a efetivação da promessa da universalização dos direitos sociais, políticos e civis, desafiando um discurso liberal que isenta o Estado das responsabilidades sociais e restringe as políticas sociais à classe social menos favorecida, ou seja, "os pobres mais pobres", reduzindo-as a medidas compensatórias, paliativas e focalizadas.

As políticas sociais devem possibilitar serviços para os cidadãos, como exemplo, a educação pública deve ser para o cidadão, independentemente de classe social, embora, o quadro nacional e o mundial revelem a emergência de atendimento das políticas básicas à população mais empobrecida e excluída. Conhecer essa realidade social e econômica que gera grande instabilidade financeira, imenso endividamento dos países pobres, especialmente o Brasil, com progressiva redução nos investimentos produtivos e redução nos índices de crescimentos econômicos em todo mundo, torna-se importante para se lutar por direitos, por trabalho, por democracia e por possibilidades de emancipação humana. Tais situações caracterizam-se como grandes desafios, especialmente para o Serviço Social, que possui um Projeto Ético-Político Profissional, pautado nesses princípios.

Assim afirma, Boschetti (2008, p.20):

O Serviço Social ao se constituir como uma profissão que atua predominantemente, na formulação, planejamento e execução de políticas públicas de educação, saúde, previdência, assistência social, transporte, habitação, tem o grande desafio de se posicionar criticamente diante da barbárie que reitera a desigualdade social, e se articular aos movimentos organizados em defesa dos direitos da classe trabalhadora e de uma sociedade livre e emancipada, de modo a repensar os projetos profissionais nessa direção. Esses são os compromissos éticos, teóricos, políticos e profissionais que defendemos no Brasil e em nosso diálogo com o mundo (on-line). 
A complexidade da sociedade atual exige um repensar contínuo do saber teórico e metodológico da profissão, da ampliação da pesquisa no conhecimento da realidade social, na produção do conhecimento sobre a organização da vida social e na busca da consolidação do projeto ético-político, por meio do exercício profissional nas atividades diárias, na inserção e participação política nas entidades nacionais de Serviço Social (CFESS/Cress, ABEPSS, Enesso), na articulação com outros movimentos sociais em defesa dos interesses e necessidades da classe trabalhadora e em luta permanente contra as imposições do neoliberalismo, contra o predomínio do capital sobre o trabalho, da violência, do autoritarismo, da discriminação e de toda forma de opressão e de exploração humana.

A busca dessa organização política exige a recusa pelo profissional do conservadorismo, do assistencialismo e das práticas funcionalistas, como parte de uma construção histórica, humana, intencional e criativa, capaz de possibilitar uma reflexão crítica, voltada para a construção do pacto democrático no Brasil, com a ampliação da cidadania por meio da implementação de políticas sociais de direito.

Outro aspecto importante para um projeto profissional e societário comprometido com uma nova sociabilidade é o trabalho que o assistente social cotidianamente formula e desenvolve, projetos que viabilizam o acesso aos direitos, que questiona o fundo público a favor dos grandes oligopólios, que luta pela socialização e pela democratização da política, que implementa serviços com qualidade aos usuários, envolvendo-os em seu planejamento, que se contrapõe às regras institucionais autoritárias e tecnocráticas (Boschetti, 2008, p.17).

Assim, é um desafio para o Serviço Social incorporar em sua formação teórico-crítica e prático-operativa a compreensão das diferentes dimensões da questão social na complexa vida moderna. O que para Costa (2006, p.73):

Pensar o conjunto de necessidades sociais que se colocam como campo potencial para a atuação do profissional do Serviço Social exige um profissional mais refinado, capaz de compreender para além da 
brutalidade da pobreza, da exclusão social, da violência, as possibilidades emancipatórias dos desejos e das escolhas significativas.

É tarefa inerente à profissão compreender a lógica de formação e o desenvolvimento da sociedade capitalista e os impasses colocados pelos conflitos sociais, tendo como campo de atuação as expressões da questão social. E nessa perspectiva, o assistente social defende a luta pela democracia econômica, política e social, busca a defesa de valores éticos para o coletivo em favor da equidade, defende o direito ao trabalho e o emprego para todos, a luta pela universalização da seguridade social, com garantia de saúde pública e previdência para todos os trabalhadores, uma educação laica, pública e universal em todos os níveis, enfim, luta pela garantia dos direitos como estratégia de fortalecimento da classe trabalhadora e mediação fundamental e urgente no processo de construção de uma sociedade emancipada. 


\title{
2 \\ As POLÍTICAS EDUCACIONAIS: DOS PRINCÍPIOS DE ORGANIZAÇÃO À PROPOSTA DA DEMOCRATIZAÇÃO
}

\author{
"O retorno da boa educação é alto para os \\ cidadãos e mais alto ainda para a sociedade."
}

José Pastore

A Educação, nos últimos tempos, ocupou lugar de destaque nas esferas econômica, política e cultural e um campo da vida social de tensão pelas disputas dos projetos societários de diferentes grupos e segmentos sociais, especialmente para conquistar-se a hegemonia política e cultural na sociedade.

Legislações brasileiras reformuladas têm defendido uma educação de acesso a todo cidadão, de qualidade e uma iminente inserção no mercado profissional e no mundo do trabalho. Mas nem sempre se tornam realidade esses discursos, não passando de meras ilusões e uma pseudoeducação. Pois milhares de crianças, adolescentes e jovens, mesmo matriculados em uma escola, permanecem excluídos de uma educação participativa, democrática, conscientizadora, dialógica, autônoma e afetiva.

Nesse capítulo, será possível refletir a história de uma educação ainda em construção, com marcas profundas da exclusão social, econômica e cultural, de uma classe menos favorecida; uma educação sem investimentos e oportunidades a essa parcela da população e sob 
o domínio de organismos nacionais e internacionais que direcionam os rumos da educação brasileira para uma ação mercantilista. Mas também é possível pensar que uma educação diferenciada, participativa e de qualidade será construída com o compromisso ético, com a paixão em socializar conhecimentos, a criatividade e a dinamicidade na construção do conhecimento pelos educadores.

\section{História da estrutura e organização do sistema de ensino no Brasil}

Freitag (1980, p.46) em seu livro Escola, Estado e Sociedade apresenta a História da Educação em três períodos, correlacionando-os a três modelos específicos da economia brasileira, ou seja, o agroexportador, o de substituição de importações e o de internacionalização do mercado interno, que estariam assim divididos:

a) $1^{\circ}$ período - de 1500 a 1930, abrangendo a Colônia, o Império e a Primeira República;

b) $2^{\circ}$ período - de 1930 a 1960 aproximadamente;

c) $3^{\circ}$ período - de 1960 em diante.

A História da Educação no Brasil inicia com a chegada dos padres jesuítas, responsáveis pelas bases de um vasto sistema educacional, ocorrendo por esse intermédio o desenvolvimento de um sistema educacional que seria o marco da educação brasileira, que evoluiu, progressivamente, com a expansão territorial da colônia, ou seja, com o predomínio da Igreja Católica na definição do sistema educacional. E, por dois séculos, eles foram quase exclusivos educadores no País.

Dessa forma, a Igreja Católica divulgava o cristianismo e a cultura europeia nos colégios e seminários dos jesuítas, atingindo com facilidade os objetivos da colonização portuguesa.

O modelo agroexportador implementado na Colônia teve como função, oferecer lucro à metrópole, sendo atingido por meio da produção de produtos primários como açúcar, ouro, café e borracha. A economia brasileira estava organizada para produzir e exportar 
gêneros de expressão econômica no comércio europeu. O objetivo da política portuguesa era alcançar grandes lucros, por meio da produção da Colônia americana. Mas a produção para exportação dependia diretamente das oscilações do mercado externo, comprometendo desastrosamente o desenvolvimento econômico da Colônia.

A estrutura social era formada basicamente por escravos, incluindo os trabalhadores, os senhores de engenho, os grandes latifundiários e os funcionários da coroa.

Obviamente, por meio dessa formação da estrutura social em que é inexistente uma política educacional de caráter estatal, pois a Colônia tinha um sistema educacional de elite e não havia interesse em ampliar a escolarização para atingir a classe subalterna. Por meio dessas reflexões, verifica-se que, desde o início, o sistema educacional é organizado e estruturado de forma excludente e seletiva.

Mas a ausência de um sistema educacional é apontada por alguns estudiosos como um entrave ao desenvolvimento econômico até nos tempos atuais.

Segundo Prado Jr. (1983, p.91), “[...] não se pode considerar sistema de ensino as magras cadeiras de primeiras letras, Latim e Grego, que havia em alguns dos maiores centros da Colônia”, criadas somente depois de 1776.

Ainda, por meio dessas reflexões, pode-se deduzir que o nível cultural da Colônia era muito baixo, e a ignorância dos colonos portugueses refletia-se na falta de habilidade e de conhecimentos técnicos, inclusive para o aprimoramento e o desenvolvimento das atividades produtivas, tanto para a agricultura quanto para a mineração (ouro, diamantes), sendo apontado também como causa de sua decadência.

Os métodos rudimentares, utilizados na agricultura pelos portugueses, eram devastadores, predatórios e orientados para o proveito imediato dos colonos, ou seja, os portugueses vinham para a Colônia em busca de riqueza e fortuna.

Nesse período, o objetivo dos portugueses era exclusivamente explorar e usufruir de toda a riqueza deste País, mas sem se preocupar com a estruturação econômica, política e educacional do povo que residia no Brasil. 
Consequentemente, essa ignorância refletia-se na falta de preocupação com o sistema educacional. Ainda, os colégios e seminários dos jesuítas que funcionavam em toda a Colônia satisfaziam as necessidades educacionais que a vida econômica impunha para a época.

Em 1808, Portugal é invadido e a família real e a corte transferemse para o Brasil, e, obviamente ocorrem modificações no plano econômico, político e social, determinados pela instalação do governo português na Colônia.

Esse fato significou uma reorganização administrativa expressiva que geraria uma crise na estrutura econômica da Colônia, porque o País produzia para exportação e não para atender a suas próprias necessidades de acordo com os interesses dos portugueses, pois a função da Colônia era enriquecer o colonizador, mas, agora os "donos" estavam residindo no País; era o início da derrocada dos portugueses, do declínio do poder e do controle de Portugal sobre a Colônia, pois com a abertura dos portos, o comércio foi subitamente ampliado, a indústria tornou-se livre, e a economia modernizou-se.

Não obstante, com a expulsão dos jesuítas, em 1759, até a transferência da corte portuguesa para o Brasil, em 1808, a educação na colônia passou por um período de desagregação e de decadência. Mas, com a chegada de D. João VI, modificou-se a política educacional que o governo português adotava em relação ao Brasil. Foram inauguradas diversas instituições educativas e culturais e surgiram os primeiros cursos superiores de Direito, Medicina, Engenharia, mas não universidades.

Diante da nova realidade, surgiu a necessidade da formação de novos quadros técnicos e administrativos para atender à demanda dos serviços criados, em função das inovações introduzidas por D. João VI.

Fundaram-se escolas técnicas e academias, para atender à demanda, pois com a abertura dos portos, intensificou-se o contato com outros países e outras culturas. Nesse período, foram criadas: a Academia Real da Marinha, a Academia Militar, o curso de cirurgia, anatomia e, depois, o curso de Medicina. E ainda, foram criados os cursos de Economia, Agricultura, Botânica, Química Industrial, 
Geologia e Mineralogia, e outros. Mas, cabe ressaltar, que a maioria dos cursos eram rudimentares em sua organização, pois focava somente a profissionalização (Freitag, 1980, p.48).

Em 1822, a partir da Independência surgiram novos ideais e a Assembleia Constituinte discutiu a importância da educação popular, e, em 1827, foi determinada em lei a criação de escolas primárias em todas as cidades e vilas mais populosas. Entretanto, essas leis não foram implementadas, passando, em 1834, para as províncias a responsabilidade da educação primária (Guiraldelli Junior, 2003, p.11).

Após a Independência, na Constituição outorgada, a ideia de um sistema educacional torna-se embrionária, quando se pretendeu garantir escolas primárias e até universidade, pois deve-se considerar que a educação não era um assunto de interesse geral. E ainda a qualidade dos cursos era insatisfatória.

A instrução secundária limitou-se à ampliação das aulas avulsas e particulares de Latim, Retórica, Filosofia, Geometria, Francês e Comércio, mas, ainda sem a fiscalização do Estado.

Mesmo a educação sendo para a elite, o atendimento à sociedade aristocrática era deficiente com relação à quantidade. Os liceus foram criados nas províncias visando amenizar o pauperismo da organização e do funcionamento escolar.

Em 1825, foi criado o Ateneu do Rio Grande do Norte. Em 1836, o Liceu da Bahia e da Paraíba e, em 1837, o Colégio Pedro II, na corte (Pinto, 1986, p.59).

A desconsideração com os problemas educacionais foi tão grande que se confirma com a lei de 15 de outubro de 1827 que teve vigência até 1946 como a única lei geral para o ensino elementar.

Um dos fatos mais marcantes ocorridos no setor educacional, durante o período de 1834 a 1889, foi a criação do Colégio Pedro II, pois tinha o papel de servir como padrão de ensino.

No período de 1860 a 1890, a iniciativa particular no sistema educacional cresceu em oposição à situação de total abandono pelo Estado. A Constituição de 1891 adotou em parte a forma de administração do sistema escolar do Império. 
Em 1890, foi criado o Ministério de Educação, Correios e Telégrafos, tendo curta duração, sendo passados os assuntos educacionais para o Ministério da Justiça (Berger, 1976 apud Pinto, 1986, p.59).

Entre 1889 a 1930, foram fundadas algumas escolas superiores e construídas muitas escolas primárias e secundárias, mas substancialmente pouco se alterou o quadro do sistema educacional. Neste período, o Estado apenas procurou garantir a manutenção dos estabelecimentos considerados como padrão para as demais escolas secundárias do País, mas não conseguiu atender aos anseios republicanos de ampliação das oportunidades educacionais, permanecendo ainda um sistema elitista, excludente e seletivo (idem).

A expansão do ensino foi lenta e irregular, por falta de uma formulação da política educacional e mesmo com a proclamação da República, em 1889, quase não alterou esse cenário, mas houve somente investimento e expansão no ensino superior, por meio da criação de muitas escolas para a formação de profissionais liberais, em atenção aos interesses de uma classe dominante para a permanência no poder.

A iniciativa particular assumiu a responsabilidade sobre o ensino secundário, em função da ausência escancarada do Estado nesse nível educacional.

As transformações ocorridas no setor econômico, político e social na Primeira República introduziram mudanças no setor cultural, pois a ideia de que a escolarização deve responder aos anseios das transformações sociais do século XX levou a um entusiasmo pela educação e a um otimismo pedagógico.

A preocupação com a ampliação da escola primária, na década de 1920, foi o ponto principal das reflexões e das discussões dos educadores e políticos.

Assim, a política educacional começa a modificar-se após a Primeira Guerra Mundial, quando surge uma geração de grandes educadores, em destaque Anísio Teixeira; ocorrem, nesse período, várias reformas do ensino nos Estados. Na década de 1930, surgem as primeiras universidades brasileiras e amplas reformas do ensino nos demais níveis, consideradas importantes, embora decorrentes 
da implementação de um regime autoritário (Guiraldelli Junior, 2003, p.21).

Em 1932, acontece o Manifesto dos Pioneiros da Educação (Movimento Escolanovista), trazendo aspectos centrais de uma ampla reforma nacional que influiu fundamentalmente nas mudanças posteriores e denunciou o atraso do sistema educacional brasileiro e a não inclusão da população a um amplo processo de educação escolarizada.

Nesse período, a cultura do "bacharelismo", ou seja, a mania da classe média em sonhar com o título de doutor como meio de enriquecimento e/ou ascensão social, foi uma constante, por este motivo é que, já em 1916, existiam 16 faculdades de Direito, com uma produção exagerada de bacharéis. Sendo o País era essencialmente ligado à agricultura, isso confirma o grande distanciamento entre a escola e o trabalho.

Com a criação, em 1924, da Associação Brasileira de Educação (ABE) pelos educadores, intelectuais, políticos e figuras de expressão da sociedade brasileira, foi possível impulsionar as discussões em torno dos problemas educacionais, por meio desta organização, sendo promovidos cursos, palestras, semanas da educação e conferências, principalmente, as Conferências Nacionais de Educação. No período de 1927 a 1929, foram realizadas três grandes Conferências Nacionais de Educação, ocorridas em Curitiba, Belo Horizonte e São Paulo.

Com a crise mundial de 1929, os anos 30 foram para o Brasil um período de sérias dificuldades, principalmente em relação à superprodução do café, o maior produto de exportação, pois com a queda dos preços do mercado internacional entrou em colapso e ocorreu o esgotamento das reservas cambiais, com o agravamento da crise nas finanças públicas.

Os anos 30 caracterizaram-se pelo desenvolvimento industrial. O governo Vargas adotou medidas para diminuir o prejuízo dos cafeicultores em decorrência da crise, sendo imposta a restrição das importações dos bens de consumo, pela falta de divisas, contribuindo consideravelmente com o fortalecimento da produção industrial. A substituição das importações resultou no fortalecimento de grupos econômicos, a nova burguesia urbano-industrial, provocando mu- 
danças no poder do Estado, em especial, na dimensão política e social. O País foi assumindo desta forma, uma política de industrialização e, consequentemente, esta mudança evidenciou uma reestruturação no seio da sociedade política e da sociedade civil, pois ao lado dos aristocratas e latifundiários do café, emergiu a burguesia financeira e industrial, e o operariado também sofreu ampliações (Freitag, 1986, p.50).

Nesse período, Getulio Vargas assumiu o poder, contando com o apoio da classe média dos grandes centros urbanos, com o auxílio de alguns grupos militares e a burguesia cafeeira.

No campo educacional brasileiro surgiram mudanças consideráveis, pois teve início um período em que se desenhou uma certa democratização no ensino, principalmente, em virtude de alguns fatores, entre eles, a discussão em torno da "escola ativa" de Dewey, tendo como seguidores no Brasil, Anísio Teixeira, Lourenço Filho, Fernando de Azevedo e Francisco Campos. Todos foram nomes renomados no Brasil e ocuparam cargos governamentais. E, mesmo por meio das influências estrangeiras, foi possível propiciar a discussão dentro dos parâmetros da realidade brasileira (Pinto, 1986, p.62).

Foi por meio das Conferências Nacionais de Educação que surgiu em 1932 o Manifesto dos Pioneiros da Escola Nova, contendo uma nova proposta pedagógica e trazendo em seu bojo uma proposta de reconstrução do sistema educacional brasileiro, visando a uma política educacional do Estado.

A criação do Ministério da Educação e Saúde em 1930 foi a medida educacional mais importante, pois tinha como papel fundamental, orientar e coordenar, como órgão central, as reformas educacionais que seriam incluídas na Constituição de 1934, tendo como seu titular Francisco Campos (idem, p.63).

Essas reformas levaram o nome de Reforma Francisco Campos e, de fato, contou com elementos importantes, como a integração entre as escolas primária, secundária e superior, e ainda, com a elaboração do estatuto da universidade brasileira. Nesse período, também foram introduzidos o ensino primário gratuito e obrigatório e o ensino religioso facultativo. 
A Constituição de 1937 absorveu parte dessa legislação e introduziu o ensino profissionalizante e tornou obrigatória para as indústrias e sindicatos a criação de escolas na esfera de sua especialidade para os filhos de seus operários ou associados.

O foco, nesse período, era essencialmente preparar os filhos dos operários para as indústrias e tal fato, concretiza-se, pois, no ano de 1942, foi criado o Serviço Nacional de Aprendizagem Industrial (Senai), e em 1946, o Serviço Nacional de Aprendizagem Comercial (Senac). E, em 1942, foi decretada a Reforma Capanema, relativa ao ensino secundário (idem, ibidem).

A chamada "redemocratização" do Brasil, no pós-Segunda Guerra Mundial, em 1945, com a promulgação da Constituição de 1946 e o surgimento do Estado populista desenvolvimentista, trouxe novas reformas, um longo período de reivindicações, surgindo um movimento em prol da escola pública, universal e gratuita, que repercutiu diretamente no Congresso Nacional e culminou com a promulgação, em 1961, da Lei de Diretrizes e Bases da Educação Nacional. As discussões em torno dessa Lei contribuíram para conscientizar o poder político sobre os problemas educacionais.

O primeiro projeto de lei encaminhado para Câmara foi o do Clemente Mariani, ministro da Educação, considerado progressista, mas que foi engavetado e sua discussão retomada apenas em 1957 (Freitag, 1980, p.58). Um novo projeto de lei foi encaminhado, agora conhecido como substitutivo Lacerda.

A Lei $n^{\circ}$ 4.024/61 resultou dos dois projetos de lei e estabeleceu que o ensino no Brasil de nível primário poderia ser ministrado pelo setor público e privado, extinguindo a obrigatoriedade do ensino gratuito nesses anos escolares. Permitiu também ao Estado subvencionar os estabelecimentos de ensino particulares, por meio de bolsas de estudo e empréstimos, e a construção, as reformas e a infraestrutura da escola.

Nesse sentido, a Lei de Diretrizes e Bases da Educação Nacional passou a ser compreendida como a medida mais importante assumida pelo Estado em relação à política educacional.

Em 1961, o presidente Jânio Quadros renuncia ao cargo, em função das pressões de grupos representados por banqueiros, gran- 
des indústrias comprometidas com o capital e o capitalismo norteamericano e executivos encarregados de defender os interesses das indústrias junto ao governo brasileiro.

Com isso, assume a presidência, nesse mesmo ano, João Goulart e apesar das dificuldades permanece no poder até 1963.

O quadro do País em 1963 é marcado pela acentuada queda do crescimento econômico, agravada pelo aumento da inflação, diminuição do poder aquisitivo do povo e um cenário político bastante conturbado.

E nesse contexto econômico, político e social, a situação da educação também não era diferente, pois os educadores, estudantes, sindicatos e partidos políticos exigiam reforma de base, consolidado por meio do Movimento de Educação de Base (MEB) que nasceu em 1958 e ampliado pelo governo Jânio Quadros, ao lado dos Centros de Cultura Popular (CCP) e dos Movimentos de Cultura Popular (MCP), que iniciaram uma campanha de mobilização nacional contra o analfabetismo (Pinto, 1986, p.65).

Esses movimentos foram marcados pela presença e interesse dos intelectuais, políticos e estudantes que favoreceram o engajamento do povo no processo de participação política e na tomada de consciência dos problemas vividos pelo Brasil no final da década de 1950.

A partir de 1964, com o início da ditadura militar, o debate popular arrefece, entretanto, o Estado amplia o sistema de ensino, inclusive o superior. Criam-se agências de apoio à pesquisa e à pósgraduação. Amplia o ensino obrigatório de quatro para oito anos. São promulgadas várias leis que introduzem reformas importantes nos diferentes níveis de ensino.

Despontava nessa época Paulo Freire, como educador imprescindível para o Brasil, principalmente, com um novo método pedagógico de alfabetização e a educação de base que visava a um processo de conscientização e de participação política por meio da aprendizagem das técnicas da leitura e da escrita.

O pensamento de Freire exerceu profunda influência nos profissionais da educação, pois seu método fundamentava-se na prática pedagógica não diretiva, que consistia em passar o homem da condição de "objeto" para a de "sujeito" (Freire, 1980 apud Pinto, 1986, p.66). 
O período da transição do autoritarismo para a democracia é marcado por forças sociais presentes no cenário político da transição democrática brasileira, como as propostas educacionais no âmbito do Estado, as propostas educacionais no âmbito da sociedade civil, a Constituição de 1988 e a eleição direta para a Presidência da República em 1989. Nesse sentido, evidenciam-se as tendências vigentes nesse período, identificando o projeto hegemônico de política educacional do Brasil contemporâneo, representado pelos ideários neoliberais, o que assinala sua maturidade por meio da privatização do sistema, especificamente para o ensino de terceiro grau.

A Lei de Diretrizes e Bases para a Educação Brasileira de 1996 é a primeira lei geral da educação promulgada desde 1961 e tem ampla repercussão sobre o sistema escolar. O governo assume a definição da política educacional como tarefa de sua competência, descentralizando sua execução para Estado e municípios. O controle do sistema escolar passa a ser exercido por meio de uma política de avaliação para todos os níveis de ensino. O que para Demo (2001, p.12) não se pode falar em inovações, no sentido de ser a "lei dos sonhos do educador brasileiro", trouxe sim, alguns dispositivos inovadores permitindo avançar em certos rumos, mas "para quem não quer mudar permanece como está".

\section{Políticas Educacionais: proposta de uma gestão participativa e uma educação de qualidade}

É importante considerar que as reformas educacionais no Brasil ocorreram mediante as crises nacionais e internacionais do sistema capitalista. Com isso a educação, em muitos momentos, foi relegada a segundo plano pelos dirigentes políticos. Dificilmente se pensou em democratizar o ensino, torná-lo acessível à classe menos favorecida economicamente e, sobretudo, priorizar a qualidade do mesmo, por questão ideológica, visto que a educação sempre esteve a serviço de um modelo econômico de natureza concentradora de rendas e socialmente excludente. 
A educação nos anos da ditadura militar sofreu o estrangulamento interno da economia com altas taxas inflacionárias, com o endividamento externo, com queda na qualidade de ensino motivada por baixos salários e investimentos públicos, com grande índice de evasão escolar e consequente crescimento da escola privada e com preferência ao ensino profissionalizante em detrimento do ensino médio.

A crise estrutural do capital, que se abateu no conjunto das economias capitalistas, a partir especialmente do início dos anos 70 (séc. $\mathrm{XX}$ ), levou o capital a desenvolver sua lógica destrutiva.

Nesse contexto, o mundo passa a iniciar profundas transformações e sem ordenamento político, econômico e social ocorrem inicialmente alterações no processo produtivo e, consequentemente, no mundo do trabalho em função da substituição do padrão produtivo taylorista e fordista ${ }^{1}$ pelas formas produtivas flexíveis e desregulamentadas denominadas toyotismo. ${ }^{2}$

Assim o mundo vivencia uma aguda destrutividade, que, no fundo, é a expressão mais profunda da crise estrutural que assola a (des)socialização contemporânea: destrói-se a força humana para o trabalho; destroçam-se os direitos sociais, brutalizam-se enormes contingentes de homens e mulheres que vivem do trabalho; torna-se predatória a relação produção/natureza, criando-se uma monumental sociedade do descartável, que joga fora tudo que serviu como embalagem para as mercadorias e seu sistema, mantendo-se, entretanto, o circuito reprodutivo do capital.

1 Taylorista/fordista: padrão produtivo capitalista desenvolvido ao longo do séc. $\mathrm{XX}$ e que se fundamentou basicamente na produção em massa, em unidades produtivas concentradas e verticalizadas, com um controle rígido dos tempos e dos movimentos, desenvolvidos por um proletariado coletivo e de massa sob forte despotismo e controle fabril (Antunes, 1996, p.79).

2 Toyotismo: expressa a forma particular de expansão do capitalismo monopolista do Japão no pós-45, cujos traços principais são: produção flexível, existência de grupos ou equipes de trabalhos utilizando-se crescentemente da microeletrônica e da produção informatizada. A produção é bastante heterogênea, os estoques são reduzidos, e há forte processo de terceirização e precarização do trabalho (idem, ibidem). 
No final dos anos 80 (séc. XX), um outro fator importante é o desmoronamento da União Soviética e do Leste Europeu, crise essa que desestruturou os partidos comunistas tradicionais e desarticulou o movimento operário e sindical em função do poder e à força da nova ideologia política, econômica e cultural. Essa categoria ficou à mercê de seus interesses, garantindo a sobrevivência e enfraquecendo sua força de luta contra a implantação desse novo projeto societário.

É ainda fator predominante da crise atual que, com a enorme expansão do neoliberalismo a partir de fins de 70 (séc. XX) e a consequente crise do Welfare State, ${ }^{3}$ se deu em um processo de regressão da social-democracia, que passou a atuar de maneira muito próxima da agenda neoliberal.

O neoliberalismo passou a deter o ideário e o programa a serem implementados pelos países capitalistas, contemplando a reestruturação produtiva, a privatização acelerada, o enxugamento do Estado, as políticas fiscais e monetárias, sintonizadas com os organismos mundiais de hegemonia do capital com o Fundo Monetário Internacional (FMI). E com isso:

A desmontagem dos direitos sociais dos trabalhadores, o combate cerrado ao sindicalismo classista, a propagação de um subjetivismo e de um individualismo exacerbados em que a cultura pós-moderna, bem como uma clara animosidade contra qualquer proposta socialista contrária aos valores e interesses do capital, são traços marcantes deste período recente. (Harvey, 1992)

Nessa contextualização, são percebidas as mudanças no mundo do trabalho e nas relações sociais por meio da precarização da maioria da população que vive do trabalho que, por sua vez, passou a viver da lógica destrutiva imposta pelo capital. Com a diminuição da absorção de mão de obra não há necessidade de se empregar grandes contingentes de funcionários.

3 Welfare State: Estado de Bem-Estar Social, ou intervencionista, surgindo após Segunda Guerra mundial, na Europa e nos Estados Unidos. Garante mínimos sociais como saúde, educação, habitação etc. 
Os serviços são terceirizados e retira-se do trabalhador todos os seus direitos assegurados por lei, criando-se assim um exército de reserva "descartável" e a exacerbação das contradições entre as exigências, a competitividade e a qualificação profissional exigidas do trabalhador para ser absorvido no mercado de trabalho. Em função do avanço tecnológico e da falta de preparo para essa empregabilidade, os trabalhadores encontram sérias dificuldades para incluir-se nesse processo e a degradação do meio ambiente com aceleração da produção sem controle da relação com a natureza, criando-se a sociedade descartável.

Essas transformações na produção e nas relações sociais buscam camuflar e neutralizar as desigualdades e as lutas de classes geradas pelo capitalismo que são aprofundadas pelo neoliberalismo. Contudo, surgem forças que se opõem por meio da prática social, das lutas populares, dos movimentos sindicais, dos grupos de pressões da sociedade civil, dos partidos políticos, idealizando uma sociedade justa.

Mediante essa rápida abordagem da situação em que a população mundial está inserida, depara-se com o desmonte de direitos sociais seguido do aumento da pobreza, do desemprego estrutural, predominando assim políticas sociais casuais, seletivas e compensatórias, minando as condições de vida de milhões de pessoas.

O padrão de bem-estar consolidado nos anos de 1940 entrou em declínio a partir de meados dos anos 70 (séc. XX), evidenciando o desmonte da cidadania social e o abalo da utopia da construção de uma sociedade de incertezas e de desamparos sociais (abordados no capítulo anterior).

Para Pereira (2001):

Atualmente, o que importa é saber como lidar com ex-sujeitos ou ex-potenciais sujeitos de direito que, embora impedidos de agir como atores sociais (porque não são mais considerados socialmente úteis) estão presentes na vida social problematizando-a e exigindo atenção.

Frente a todos esses acontecimentos, faz-se necessário analisar como o Brasil vem enfrentando essas transformações. 
Dados estatísticos confirmam a posição do Brasil a favor desta política neoliberal, por meio de sua posição política, econômica e ideológica: um país situado na América do Sul, subdesenvolvido, caracterizado com forte concentração de renda e sem condições reais de sair das margens de exclusão que lhes são impostas.

O Banco Mundial, no relatório sobre Indicadores do Desenvolvimento Mundial, no final de década de 1990, registrou dados que, no Brasil, 37,7 milhões de pessoas ganham menos de 1 real por dia ou 30 reais por mês. O País abriga $4 \%$ dos pobres do mundo. E ainda $20 \%$ da população (cerca de 30 milhões de pessoas) concentram em suas mãos $67 \%$ da renda nacional, que está atualmente em torno de 860 milhões de dólares. Significando que 32 milhões de brasileiros têm em mãos cerca de 576 bilhões de dólares, sendo uma média de 18 mil dólares anuais por pessoa (Benedito, 2000). No cenário mundial, o capitalismo contemporâneo é marcado pela crescente e desigual repartição da riqueza mundialmente produzida, já que os $20 \%$ mais ricos do mundo ficam com mais de $80 \%$ do PIB mundial e na ampliação da pobreza, já que o número de pobres cresce ao ritmo do crescimento da população, $2 \%$ ao ano, o que faz que um bilhão e meio de seres humanos vivam em condição de mera sobrevivência (Diesse, 2007).

O próprio Instituto de Pesquisa Econômica Aplicada do governo federal enfatiza que a desigualdade de renda brasileira permanece extremamente elevada, muito acima de outros países com grau de desenvolvimento ao Brasil. Ainda o País continua com as mais elevadas taxas de concentração de renda, de riqueza e de propriedade: os 10\% mais pobres ficam com apenas $1,1 \%$ da renda do trabalho, enquanto os $10 \%$ mais ricos ficam com $44,7 \%$ (Diesse, 2007). É inaceitável que o País que se situa entre as dez nações mais ricas do mundo mantenha uma estrutura econômica e social na qual $13 \%$ da renda do trabalho se concentram nas mãos de apenas $1 \%$ da população, ou seja, nesse país de 184,3 milhões de pessoas, 13\% da riqueza estão no poder de apenas 1,84 milhões de pessoas (Boschetti, 2008, p.12).

O que se vive hojeé a denominada globalização do capital que tem por fundamento os ideais neoliberais que transformam a sociedade 
em sociedade de risco. Rompem-se as garantias sociais como fato e como expectativa. O resultado maior é o crescimento da exclusão social.

Portanto, consequências dessa exclusão imposta aos brasileiros podem ser facilmente visualizadas no crescente número de crianças e de adolescentes em risco, no início do novo século, com 34,6 mortes por mil nascimentos, nas ruas, explorados pelo trabalho infantojuvenil, fora da escola (13,3\% de analfabetos na faixa etária de 15 anos ou mais) e com uma educação sem qualidade, pedintes, vítimas de violência sexual. Nota-se ainda um elevado índice de crimes cometidos por adolescentes, e outros decorrentes de uma política neoliberal e por esse sistema vigente de acumulação (Informativo da Pastoral do Menor, maio/junho 2001, n⿳3 36).

Nesse sentido, de um modo geral, as políticas sociais brasileiras estão diretamente relacionadas às condições vivenciadas pelo País em nível econômico, político e social. A inserção passiva e dependente do mundo globalizado faz que o Brasil assuma as determinações ditadas pelo grande capital e pelas nações hegemônicas, principalmente os Estados Unidos.

Em geral, reconhece-se que a existência de políticas sociais é um fenômeno associado à constituição da sociedade burguesa, ou seja, do específico modo capitalista de produzir e reproduzir-se.

No Brasil, as políticas sociais públicas ${ }^{4}$ sempre foram sinônimo de assistência, filantropia ou benesse. O Estado intervém nas questões sociais por meio de medidas parcelares, com o objetivo em primeiro lugar, de manter a ordem social.

4 Política Social (Pública) : linha de ação coletiva que concretiza direitos sociais declarados e garantidos em Lei. É mediante as políticas públicas que são distribuídos ou redistribuídos bens e serviços sociais, em resposta às demandas da sociedade. Por isso, o direito que as fundamenta é um direito coletivo e não individual. Embora as políticas públicas sejam de competência do Estado, não representam decisões autoritárias do governo para a sociedade, mas envolvem relações de reciprocidade e antagonismo entre essas duas esferas (Pereira, 1996, p.130 apud Raichelis, 2000 p.59). 
A política social brasileira compõe-se e recompõe-se, conservando em sua execução o caráter fragmentário, setorial e emergencial, sempre sustentada pela imperiosa necessidade de dar legitimidade aos governos que buscam bases sociais para manter-se e aceitam seletivamente as reivindicações e até as pressões da sociedade. (Vieira, E., 1995, p.68)

No que diz respeito às políticas educacionais, mesmo que se tenha respondido com algumas reformas legais aos direitos da população infanto-juvenil, depois da reforma Constitucional de 1988, por meio do Estatuto da Criança e do Adolescente - Lei Federal 8.069/905 e a Lei de Diretrizes e Base da Educação Nacional - Lei Federal 9394/96, depara-se com uma enfraquecida política educacional e os programas existentes não superam a demanda e tão pouco garantem o direito à educação previsto nas leis brasileiras.

A Constituição Federal de 1988, promulgada após amplo movimento de redemocratização do País, marca um novo período. Ampliam-se as responsabilidades do Poder Público e da sociedade em geral para com a educação, a partir das novas demandas do mundo moderno e globalizado, em atendimento ao ideário neoliberal. Essa Lei apresenta o mais longo capítulo sobre a educação de todas as Constituições Brasileiras, pois apresenta dez artigos específicos (art. 205 a 214) que detalham a matéria, que também figura em quatro artigos do texto constitucional (Art. 22, XXIV; 23, V; 30,VI e Art. 60 e 61 das Disposições Transitórias.

5 Lei Federal 8.069/90 - Estatuto da Criança e do Adolescente - Art. 53: “A criança e o adolescente têm direito à educação, visando ao pleno desenvolvimento de sua pessoa, preparo para o exercício da cidadania e qualificação para o trabalho, assegurando-se-lhes: I- igualdade de condições para o acesso e permanência na escola; II- direito de ser respeitado pelos seus educadores; IIIdireito de contestar critérios avaliativos, podendo recorrer a instâncias escolares superiores; IV- direito de organização e participação em entidades estudantis; $\mathrm{V}$ - acesso a escola pública e gratuita próxima a sua residência. Parágrafo Único: é direito dos pais ou responsáveis ter ciência do processo pedagógico, bem como participar das propostas educacionais. 
Apesar dos poucos avanços no texto promulgado, reconhecidos pelos educadores, há de se ressaltar algumas conquistas defendidas pela categoria, tais como: a consagração da educação como direito público subjetivo (Art. $208 \S 1^{\circ}$ ); o princípio da gestão democrática do ensino público (Art. 206, VI); o dever do Estado em prover creche e pré-escola às crianças de 0 a 6 anos de idade (Art. 208,IV); a oferta de ensino noturno regular (Art. 208,VI); o ensino fundamental obrigatório e gratuito inclusive para os que a ele não tiveram acesso em idade própria (Art. 208,I); o atendimento educacional especializado aos portadores de necessidades especiais (Art. 208,III).

Antes mesmo da promulgação da Constituição Federal, em 5 de outubro de 1988, inicia-se o debate em torno da Lei de Diretrizes e Bases da Educação Nacional por parte das organizações de educadores. E apesar de toda esta movimentação por parte dos educadores, o deputado Octávio Elísio dá entrada na Câmara dos Deputados do primeiro projeto de LDB, conhecido como Projeto n $1258 / 88$, de sua autoria.

No período de 1990 a 1992, com Collor de Mello à frente da presidência do Brasil, a política educacional é relegada a segundo plano. E ainda é vista pelos educadores, especialistas e a imprensa em geral, como a educação um dos pontos fracos do governo, tornando-se manchetes de jornais.

Em seguida, com a presidência de Itamar Franco, ocorre a tentativa de retomada da definição da política educacional e tal intenção se materializa por meio de um processo de mobilização nacional, acontecendo em dois momentos importantes.

A educação nos dias atuais assume novos contornos na sociedade brasileira e especialmente entre os educadores, que, por excelência, buscam assumir o compromisso de socializar, construir e desvendar novos conhecimentos.

A Constituição de 1988 demarca na realidade brasileira, uma nova ordem política quando declara como um de seus princípios, o da descentralização político-administrativa que garante à sociedade o direito de formular e de controlar políticas, configurando um redimensionamento nas tradicionais relações entre Estado e sociedade civil. 
Assim, nos anos 90, o tema descentralização passa a ser estudado na educação brasileira, e a temática "gestão na educação" tem ocupado vários espaços de debates, por diversos segmentos conservadores e progressistas com suas reflexões e proposições ideológicas, políticas e sociais. Nesse sentido, afirma Lück et al. (2000, p.9):

O ensino público no Brasil está experimentando transformações profundas. Reformas nacionais juntamente com iniciativas em âmbito estadual e municipal estão alterando as práticas pedagógicas e a organização escolar, na tentativa de dar eficácia à escola e universalizar o seu acesso. Nunca antes na histórica do Brasil a questão da educação pública foi tão evidente na mídia, na vida política e na consciência do cidadão comum. Vem-se reconhecendo amplamente que a educação é um elemento fundamental no desenvolvimento social e econômico e que o ensino no Brasil, especialmente aquele oferecido por setores públicos é insatisfatório diante dos padrões internacionais, tanto na sua quantidade, quanto na sua qualidade.

Com essa política de descentralização educacional e de gestão na escola pública, tem-se dado ênfase à participação da comunidade escolar, como as famílias, os alunos, funcionários da escola, educadores em geral, para a elaboração da proposta pedagógica de cada escola. E um espaço privilegiado para a experiência desse processo participativo é o Conselho Escolar. Entretanto sua constituição e o funcionamento não determinam uma efetiva participação cidadã. Mas a sociedade civil organizada espera uma verdadeira representatividade política dos conselheiros e que possam influenciar nas decisões e na dinâmica cotidiana das escolas. Busca-se por meio dos conselhos a abertura de espaço para o exercício da cidadania, o aprendizado das relações sociais democráticas e a formação de cidadãos participativos na luta por uma escola flexível, aberta e sensível aos interesses da comunidade e que rompa com uma cultura autoritária, centralizadora e dominante.

O Conselho Escolar é um dos mais importantes mecanismos de democratização da gestão de uma escola. Assim, quanto mais ativa e 
ampla for a participação dos membros do conselho na vida da escola, maiores serão as possibilidades de fortalecimento dos mecanismos de participação e de decisão coletivos.

Pensar a democratização do ensino e/ou da escola implica definir objetivamente sua função social, para que e a quem serve, e propor uma educação de qualidade.

Afirmam Lück et al. (2000, p.13) que:

A institucionalização da democracia e, simultaneamente, o aprimoramento da eficiência e da qualidade da educação pública têm sido uma força poderosa a estimular o processo de mudanças na forma de gerir escolas no Brasil. A participação da comunidade escolar, incluindo professores, especialistas, pais, alunos, funcionários e diretor, é parte desse esforço que promove o afastamento das tradições corporativas e clientelistas, prejudiciais à melhoria do ensino por visarem ao atendimento a interesses pessoais e de grupos.

A educação implica todas as buscas do humano para apropriar-se da cultura produzida pelo próprio ser humano. A escola é o espaço privilegiado de produção e socialização do saber e deve se organizar por meio de ações educativas que busquem a formação de sujeitos éticos, participativos, críticos e criativos. Isso significa que compete à escola o papel de contribuir para a disseminação do saber historicamente acumulado e também a produção de novos saberes. Nesse sentido, a participação dos diversos atores é um aspecto relevante para e efetivação da democratização da escola e da gestão.

No que diz respeito à gestão, Lück et al. (2000, p.13-4) apresentam que:

O movimento pela gestão democrática em educação reconhece a necessidade de unir mudanças estruturais e de procedimentos com ênfase no aprimoramento escolar; por meio de um projeto pedagógico compromissado com a promoção de educação em acordo com as necessidades de uma sociedade moderna e justa. 
A gestão democrática pode ser considerada como meio pelo qual todos os segmentos que compõem o processo educativo participem da definição dos novos rumos que a escola deve imprimir à educação e do modo de implementar essas decisões, por meio de um processo contínuo de avaliação de suas ações. Pode-se apontar como elementos constitutivos dessa forma de gestão, a participação, a autonomia, a transparência e a pluralidade, viabilizados por meio de instrumentos diretos de sua ação nos conselhos escolares como espaços de participação e de decisões.

É importante considerar que a democratização da educação, aqui apresentada, extrapola as ações voltadas para a ampliação do atendimento escolar. É por meio dessa postura assumida pelos sujeitos e dirigentes educacionais que participam do processo educativo, que se inaugura o sentido democrático da prática social da educação.

\section{A política educacional e as diretrizes do ensino em Serviço Social}

Para pensar o Serviço Social como parte integrante da política educacional brasileira, é necessário considerar o modelo econômico adotado pelo País no início do século XX e ratificado pelo movimento de 1964 pautado na internacionalização do capital. Alteraram-se "os padrões do desenvolvimento econômico, que passaram a ser sustentados pela hegemonia dos consórcios internacionais" (Furtado, 1972 apud Pinto, 1986, p.115).

Diante disso, o País precisou criar um padrão de consumo para atender à demanda do mercado interno com tecnologia mais avançada segundo as exigências internacionais, além de investir no crescimento de mão de obra qualificada para atender a essas exigências tecnológicas e burocráticas.

Com a vinda das empresas multinacionais ao País e o investimento na iniciativa privada, o País criou mão de obra excedente, com salários baixos, visando a uma grande lucratividade. E para essa 
implantação da tecnologia mais avançada, o governo buscou recursos no capital estrangeiro.

Nesse sentido, afirma Pinto (1986, p.116) que a dívida externa aumentou assustadoramente, desencadeando avassaladora crise econômica no País.

A desmistificação do "milagre" da década de 1970, o endividamento externo crescente devido à alta da taxa dos juros do sistema financeiro internacional, a inflação galopante em três dígitos e os acordos com o FMI (Fundo Monetário Internacional), sobretudo a partir da década de 1980, acarretaram uma drástica recessão econômica, aprofundando o empobrecimento da classe trabalhadora, quer pelo arrocho salarial (via autoritarismo do Estado), quer pelo alto índice de desemprego e subemprego.

Já na década de 1980, as políticas sociais, bem como a política educacional, foram ajustadas ao modelo econômico e em tempos de incertezas foram desvalorizadas.

Se por um lado a educação aliou-se ao projeto ideológico, como instrumento de desenvolvimento e capacitação da classe trabalhadora para o acesso à estrutura dominante, por outro, o Estado valorizou a educação como "salvação nacional" (idem, ibidem), colocando-a a seu serviço, para realizar o projeto político e econômico, tendo-se, consequentemente, uma desvalorização da educação, especialmente no que diz respeito à crescente privatização do ensino em nível superior.

A recessão econômica trouxe ao País altas taxas de desemprego e de subemprego, a luta pela manutenção do emprego a qualquer custo e atingiu diretamente o sistema educacional, desmistificando o desejo do jovem em conquistar um diploma e o título para enfrentar o desemprego ou assumir as mesmas atividades que exercia antes de ingressar no ensino superior.

Nas décadas posteriores, a crise financeira assume novos formatos, o Brasil tem vivido um fenômeno educacional com o aumento desordenado de instituições de ensino superior presencial e a distância, vislumbra-se um exército intelectual de reserva, e muitas vezes 
sem qualificações, um alto índice de concorrência ocasionando a queda do nível salarial dos docentes e a irrelevância pelos diversos títulos de qualificação.

No que diz respeito ao ensino do Serviço Social, a formação profissional é marcada por toda essa realidade brasileira e pelas pressões do sistema educacional brasileiro. Entretanto, sua história, desde os anos 80 , é pautada por denúncias dos descasos políticos, pela falta de investimento na estrutura das organizações e do corpo docente e discente das instituições de ensino, e pela precarização do ensino superior que tem sido alvo de uma política mercantilista, injusta e excludente nos mercados nacionais e internacionais.

O Serviço Social impulsionado pelos problemas econômicos gerados pelas crises financeiras mundiais e profundamente questionado pela situação de miserabilidade e de exclusão da classe trabalhadora e de baixo poder econômico, desde a década de 1960, questiona sua identidade profissional por meio do Movimento de Reconceituação (será exposto no Capítulo 3).

Essa inquietude na categoria profissional repercute em vários aspectos da profissão, especialmente na formação profissional com uma primeira revisão curricular nos anos 80 efetivada pela elaboração do Currículo Mínimo de 1982 e pelas atuais diretrizes curriculares de 1996.

A discussão da reforma curricular de 1982 expressou uma reorientação radical da formação profissional, motivada pelo movimento de democratização do País com a marca de politização nos debates sociais e pela revisão ética, política e teórico-metodológica do próprio Serviço Social. O que segundo Almeida (2000, p.8), “[...]o currículo de 1982 representou uma profunda reorganização da formação profissional alicerçada social, ocupacional e academicamente em mudanças no cenário político e institucional tanto na sociedade brasileira quanto da profissão".

É a partir dos anos 80 que a profissão estabeleceu uma interlocução com a teoria social de Marx como referência analítica. Com isso, torna-se "[...] hegemônica no Serviço Social a abordagem do Serviço Social como totalidade social que participa do processo de 
reprodução das relações contraditórias da sociedade capitalista" (Yazbek et al., 2008, p.19).

Tal referencial marxista avança para os anos 90 e imprime um direcionamento no pensamento e ação do Serviço Social no Brasil, com rebatimento na formação profissional, na elaboração dos trabalhos acadêmicos e científicos (congressos, convenções, seminários e outros), na regulamentação do exercício profissional e no novo Código de Ética de 1993 (Netto, 1996, p.111).

Na década de 1990, a categoria profissional, impulsionada pelas mudanças da realidade social, trabalhando cotidianamente com as mazelas da pobreza e as diversas faces da exclusão social, busca a construção de seu projeto ético-político pautado na justiça social, na igualdade e na garantia de direitos sociais a todos os cidadãos.

Com isso, a proposta de uma implementação do novo currículo em Serviço Social trouxe o rompimento com práticas conservadoras da profissão desde sua origem, a revisão de sua identidade e o compromisso com a formação ética frente às exigências do mercado de trabalho.

Nesse sentido, Iamamoto (2005, p.16) afirma a evolução histórica da profissão e os novos posicionamentos éticos e políticos frente à realidade brasileira.

O Serviço Social, no marco de sua renovação crítica, vem afirmando o compromisso profissional com os interesses dos usuários e com a qualidade dos serviços prestados, afirmando uma nova forma de pensar e realizar o trabalho profissional, em contraposição à herança conservadora do passado, orientada por uma perspectiva teórico-metodológica apoiada na teoria crítica, e em princípios éticos de um humanismo radicalmente histórico. A profissão apresenta uma grade acadêmica e social renovada, voltada à defesa dos direitos de cidadania e dos valores democráticos, na perspectiva da liberdade, da equidade e da justiça social. $\mathrm{O}$ assistente social tem demonstrado um compromisso efetivo com os interesses públicos, atuando na defesa dos direitos sociais dos cidadãos e cidadãs brasileiros e na sua viabilidade junto aos segmentos majoritários da população. 
O Serviço Social viveu nos anos 1993 a 1996 o processo de elaboração do novo Currículo Mínimo, sendo aprovado pela Assembleia Geral Extraordinária no dia 8 de dezembro de 1996 na Universidade do Estado do Rio de Janeiro. Após sua aprovação pelo fórum máximo da entidade, a proposta começou a tramitar no Ministério da Educação e do Desporto (MEC) e, seguindo as orientações da nova Lei de Diretrizes e Bases da Educação Nacional (Lei de dezembro de 1996) teve de alterar a expressão "currículo mínimo", vigente até então, requerida pela nova legislação "Diretrizes Gerais". O processo de aprovação das Diretrizes Gerais para o curso de Serviço Social teve mais que uma alteração de título, começou a depender de novas leis complementares que regulamentam a educação superior no País. Apesar dessas mudanças, a Associação Brasileira de Ensino e Pesquisa em Serviço Social (ABEPSS) teve como princípio político e acadêmico aguardar a aprovação final do documento enviado ao Ministério da Educação (MEC), enfatizando, contudo a validade e pertinência das orientações pedagógicas e de conteúdos aprovados em assembleia da entidade como parâmetro para os processos de discussão sobre ajustes, revisões e alterações dos currículos plenos (ABESS/CEDEPSS, 1997).

Para Almeida (2000, p.14), a proposta contida nas Diretrizes Gerais tem como ideia principal que o desafio para qualquer projeto de formação profissional nos dias de hoje é o de assegurar à sociedade a entrada no mundo do trabalho de profissionais solidamente embasados em seu ofício e que sejam capazes de aliar a competência técnica e política a um explícito sentido ético. Tal objetivo deve ser concretizado por meio de um processo de acúmulo intelectual adquirido pela profissão em um processo dialético contínuo de atualização, impedindo que as diretrizes básicas da formação profissional se percam.

O tema central do processo de construção desse novo currículo para o curso de Graduação em Serviço Social foi a questão social, entendida no âmbito da produção e reprodução da vida que tem no trabalho seu elemento fundante. Tal perspectiva articula organicamente a profissão e a realidade (ABESS/CEDEPSS, 1997). 
A nova abordagem dessa proposta curricular implica refletir a prática profissional como processo de trabalho, considerando que a profissão está inserida no trabalho coletivo responsável pelo movimento de produção e reprodução da vida social, é determinada pelas condições macrossociais, e concretizada historicamente pelos sujeitos que a realizam e a concretização das políticas sociais como elementos constitutivos do trabalho do assistente social, enquanto possibilidade de respostas ao enfrentamento da questão social. Esta como expressão das desigualdades e lutas sociais, em suas múltiplas manifestações, constitui a matéria-prima sobre a qual incide o trabalho profissional.

Segundo a Associação Brasileira de Ensino em Serviço Social ${ }^{6}$ (1996), na década de 1990, o profissional construiu bases para sua formação profissional em uma matriz materialista histórica. As Diretrizes Curriculares da formação do Assistente Social no Brasil gestam-se como fruto de um amadurecimento do debate teórico na produção de conhecimento da área que busca raízes no Movimento de Reconceituação Profissional da década de 1960. Essas Diretrizes contêm indicativos ético-políticos, teórico-metodológicos e técnico-operativos que encaminham a análise da realidade a partir do método dialético marxista. O fundamento dessas diretrizes está na análise da relação capital e trabalho como essência do processo de desenvolvimento social.

As atuais Diretrizes Curriculares apontam a formação em Serviço Social para a capacitação do profissional em: apreender criticamente o processo histórico como totalidade, conhecer a formação histórica e social brasileira por meio do desenvolvimento do capitalismo e da profissão, apreender o significado social da profissão, bem como suas demandas para desvelar novas possibilidades de articulação entre o público e o privado e formular respostas profissionais que possibilitem o enfrentamento da questão social (Yazbek et al., 2008, p.24).

Diante dessa realidade conquistada pelos assistentes sociais, muitos desafios são colocados ao profissional no árduo movimento

6 A ABESS mudou sua designação para ABEPSS - Associação Brasileira de Ensino e Pesquisa em Serviço Social no ano de 1998 por exigências estatutárias. 
de construção de direitos sociais, tais como: o incansável exercício da consolidação do projeto ético-político por meio de ações que concretizem seus valores, a busca contínua pela qualificação profissional em combate à mercantilização e precarização do ensino brasileiro e do ensino no Serviço Social, a inserção do profissional nos processos de construção de uma sociedade democrática e participativa, a organização da categoria na busca da regulamentação dos vínculos contratuais e melhores condições salariais e de trabalho ao profissional.

Finalmente, segundo Yazbek et al. (2008, p.31), o assistente social tem a difícil tarefa de propor e possibilitar uma nova "cultura que torne indeclináveis os direitos da população com a qual trabalhamos”. 



\title{
3 \\ O Serviço Social na \\ CONTEMPORANEIDADE: DEMANDAS E RESPOSTAS
}

\author{
“Ensinar é não transmitir certezas”.
}

Arnold Schöenberg

O Serviço Social é uma profissão inserida na divisão social e técnica do trabalho, realiza sua ação profissional no âmbito das políticas socioassistenciais, na esfera pública e privada. Neste sentido, desenvolve atividades na abordagem direta da população que procura as instituições e o trabalho do profissional e por meio da pesquisa, da administração, do planejamento, da supervisão, da consultoria, da gestão de políticas, de programas e de serviços sociais.

Segundo José Filho (2002, p.56):

O Serviço Social atua na área das relações sociais, mas sua especificidade deve ser buscada nos objetivos profissionais tendo estes que serem adequadamente formulados guardando estreita relação com objeto. Essa formulação dos objetivos garante-nos, em parte, a especificidade de uma profissão. Em consequência, um corpo de conhecimentos teóricos, método de investigação e intervenção e um sistema de valores e concepções ideológicas conformariam a especificidade e integridade de uma profissão. O Serviço Social é uma prática, um processo de atuação que se alimenta por uma teoria e 
volta à prática para transformá-la, um contínuo ir e vir iniciado na prática dos homens face aos desafios de sua realidade.

$\mathrm{O}$ assistente social é um profissional que tem como objeto de trabalho a questão social com suas diversas expressões, formulando e implementando propostas para seu enfrentamento, por meio das políticas sociais, públicas, empresariais, de organizações da sociedade civil e movimentos sociais. Para Netto (1992, p.71), "a questão social, como matéria de trabalho, não esgota as reflexões". Sem sombra de dúvidas, ela serve para pensar os processos de trabalho nos quais os assistentes sociais, em uma perspectiva conservadora, eram "executores terminais de políticas sociais", emanadas do Estado ou das instituições privadas que os emprega.

No processo de ruptura com o conservadorismo, o Serviço Social passou a tratar o campo das políticas sociais, não mais no campo relacional demanda da população carente e oferta do sistema capitalista, mas acima de tudo como meio de acesso aos direitos sociais e à defesa da democracia. Dessa forma, não se trata apenas de operacionalizar as políticas sociais, embora importante, mas faz-se necessário conhecer as contradições da sociedade capitalista, da questão social e suas expressões que desafiam cotidianamente os assistentes sociais, pensar as políticas sociais como respostas a situações indignas de vida da população pobre e com isso compreender a mediação que as políticas sociais representam no processo de trabalho do profissional, ao deparar-se com as demandas da população.

A atuação do assistente social realiza-se em organizações públicas e privadas e em diferentes áreas e temáticas, como: proteção social, educação, programas socioeducativos e de comunidade, habitação, gestão de pessoas, segurança pública, justiça e direitos humanos, gerenciamento participativo, direitos sociais, movimentos sociais, comunicação, responsabilidade social, marketing social, meio ambiente, assessoria e consultoria, que variam de acordo com o lugar que o profissional ocupa no mercado de trabalho, exigindo deste um conhecimento teórico-metodológico, ético-político e técnico-operativo.

Esse profissional busca a inclusão social e a participação das classes subalternas, por meio de formas alternativas e estratégicas 
de ação. Pois procura conhecer a realidade em que atua e possuir compromisso ético com a classe trabalhadora e com a qualidade dos serviços prestados.

Para uma reflexão do Serviço Social na atualidade, com suas demandas e perspectivas nesse momento histórico, é necessário situá-lo em sua trajetória histórica e revelar o legado desse momento com seus rebatimentos no contexto do século da globalização. Tempos em que a economia e o ideário neoliberal intensificam as desigualdades sociais com suas múltiplas faces. Tempos em que crescem as massas descartáveis, sobrantes e à margem dos direitos e sistemas de proteção sociais. Tempos, portanto em que crescem as demandas por políticas sociais, de um modo geral e, particularmente, por políticas de proteção social (Yazbek, 2000, p.95-8), entre as quais se destaca, neste estudo, a Educação, como campo privilegiado e desafiador para o exercício profissional, é o que será discutido a seguir.

\section{Do legado da história aos desafios atuais da profissão}

O surgimento e desenvolvimento do Serviço Social como profissão é resultado das demandas da sociedade capitalista e suas estratégias e mecanismos de opressão social e reprodução da ideologia dominante. Como profissão que surge de uma demanda posta pelo capital, institucionaliza-se e legitima-se como um dos recursos mobilizados pelo Estado e pelo empresariado, mas com um suporte de uma prática cristã ligada à Igreja Católica, na perspectiva do enfrentamento e da regulação da chamada questão social que, a partir dos anos 30 (séc. XX), adquire expressão política pela intensidade das manifestações na vida social cotidiana.

Conforme afirma Yazbek (2000b, p.92):

Terá particular destaque na estruturação do perfil da emergente profissão no país a Igreja Católica, responsável pelo ideário, pelos conteúdos e pelo processo de formação dos primeiros assistentes 
sociais brasileiros. Cabe ainda assinalar, que nesse momento, a questão social é vista a partir de forte influência do pensamento social da Igreja, que a trata como questão moral, como um conjunto de problemas sob a responsabilidade individual dos sujeitos que os vivenciam, embora situados dentro de relações capitalistas. Tratase de um enfoque individualista, psicologizante e moralizador da questão, que necessita para seu enfrentamento de uma pedagogia psicossocial, que encontrará no Serviço Social efetivas possibilidades de desenvolvimento.

O surgimento do Serviço Social está intrinsecamente relacionado com as transformações sociais, econômicas e políticas do Brasil nas décadas de 1930 e 1940, com o projeto de recristianização da Igreja Católica e a ação de grupos, classes e instituições que integraram essas transformações. Essas décadas são marcadas por uma sociedade capitalista industrial e urbana. A industrialização processavase dentro de um modelo de modernização conservadora, pois era favorecida pelo Estado corporativista, centralizador e autoritário. Assim, a burguesia industrial aliada aos grandes proprietários rurais, buscava apoio principalmente no Estado para seus projetos de classe e, para isso, necessitavam encontrar novas formas de enfrentamento da chamada "questão social".

O Estado Novo visando garantir o controle social e sua legitimação, apoia-se na classe operária por meio de uma política de massa, capaz ao mesmo tempo de "defender" e de reprimir os movimentos reivindicatórios. Ele se constitui na "versão brasileira atenuada do modelo fascista europeu", ou seja, as diretrizes assumidas pelo governo Vargas baseavam-se nos modelos corporativos europeus (Yazbek, 1980, p.24). Esta ação vai desde uma legislação social protetora até uma estrutura sindical, o Estado "lhe concede o direito potencial à reivindicação e lhe concede a cidadania” (idem, p.25), mas em contrapartida, subtrai-lhe a possibilidade de uma organização política autônoma e com isso cria um aparato institucional assistencial que irá atender muito mais ao elevado nível econômico do mercado do que às necessidades da população. A política Vargas tem duas posturas 
contraditórias em relação aos operários, a conciliação e a repressão, ou seja, o ditador buscava obter "apoio" das classes trabalhadoras, inicialmente, pela legislação da Previdência Social, depois pelo controle das estruturas sindicais, controle esse que assumiu diversas formas repressivas.

A implementação dessas ações governamentais ocorre no momento em que a proposta de institucionalização do Serviço Social começa a existir. Na América Latina, bem como no Brasil, a Igreja ainda desenvolvia quase que exclusivamente sua intervenção no campo de ação social por meio das chamadas obras de caridade e assistência, que envolviam em suas ações a burguesia e especialmente o segmento feminino.

A formação profissional dos primeiros assistentes sociais brasileiros dá-se a partir da influência europeia, por meio do modelo franco-belga que, tendo como base princípios messiânicos (tomistas) de salvar o corpo e a alma, e fundamentava-se no propósito de "servir ao outro".

Como afirma Silva (1995, p.40):

O modelo franco-belga, limitou-se, portanto, a uma formação essencialmente pessoal e moral sendo, nesse período, o Serviço Social assumido como uma vocação, e a formação moral e doutrinária, enquanto cerne da formação profissional, visou, sobretudo, formar o assistente social para enfrentar, com subjetividade, a realidade social.

A partir dos anos 40, abre-se um novo horizonte no campo da profissionalização da assistência, que, mesmo ainda estreitamente ligada a sua origem católica, com as ideias e princípios da "caridade", da "benevolência" e da "filantropia", próprios do universo neotomista, tem sua atividade legitimada pelo Estado e pelo conjunto da sociedade, por meio da implementação de grandes instituições assistenciais. Nesse quadro, o Serviço Social busca uma instrumentalização técnica, valorizando o método e desvinculando-se dos princípios neotomistas para se orientar pelos pressupostos funcionalistas da sociologia e assim poder responder às novas exigências colocadas pelo mercado. 
A linguagem do "investimento", da técnica, do planejamento passa a ser um referencial importante, constituindo-se com isso, uma das bases para o processo de profissionalização do Serviço Social.

O processo de institucionalização e de legitimação do Serviço Social desvencilha suas origens da Igreja, contudo não supera o ranço conservador, quando o Estado passa a gerir prioritariamente a política de assistência, efetivada direta ou indiretamente pelas instituições por ele criadas ou a ele associadas. A assistência deixa de ser um serviço prestado exclusivamente pelas instituições privadas, tendo novos parceiros como o Estado e o empresariado.

O desenvolvimento do capitalismo e a inserção da classe operária no cenário político da época cria o fundamento necessário à institucionalização da profissão. A chamada "questão social" manifesta-se por meio de vários problemas sociais (fome, desemprego, violência e outras) que exigem do Estado e do empresariado uma ação mais efetiva e organizada. A demanda do trabalho profissional (assistente social), portanto, vem no bojo de uma demanda apresentada pelo setor patronal e pelo Estado.

Também se diferencia no que diz respeito à população atendida, quando antes uma pequena parcela da população tinha acesso aos serviços das obras assistenciais privadas, agora um maior número do proletariado tem acesso às incipientes políticas sociais criadas pelo Estado. Essa mudança substancial altera também o vínculo profissional, pois o Estado e o empresariado passam a ser os grandes empregadores de Assistentes Sociais, dando um contorno diferenciado ao exercício profissional.

Sob a égide do pensamento da Igreja, a atuação profissional estava impregnada da ideia de "fazer o bem", de legitimar a doutrina social da Igreja. O Serviço Social no Brasil, assim como na Europa, frente à fragilidade teórica, com uma formação mais moral e ética, e à complexidade da realidade social, fez uso dos ensinamentos da Igreja para executar sua prática, e esta usava o Serviço Social para expandir sua doutrina, sua visão de homem e de mundo.

Com isso, o pensamento conservador e a influência da doutrina católica traçaram um perfil de ação para os profissionais de Serviço 
Social atrelados ao pensamento burguês, atribuindo-lhes tarefas de amenizar conflitos, recuperar o equilíbrio e preservar a ordem vigente, com frágil consciência política, pois envolvida pelo "fetiche" da ajuda, não conseguia ter claro as contradições do exercício profissional (Martinelli, 2000, p.127).

Essas características do Serviço Social brasileiro, no período inicial de sua existência, são marcantes, e dizem respeito a uma profissão aceita não só pela Igreja, mas principalmente pelo Estado e pela burguesia. Seu componente técnico-operativo incorpora formas tradicionais de assistência social e da própria ação social, tais como: estudo das necessidades individuais, triagem dos problemas, concessão de ajuda material, aconselhamentos, inserção no mercado de trabalho, triagem, visitas domiciliares, encaminhamentos, aulas de tricô e outros trabalhos manuais, atividades voltadas à educação ou a orientações sobre moral, higiene, orçamento, entre outros.

Nos anos 40, surgem os métodos importados dos Estados Unidos, Serviço Social de Caso e, ainda que este predomine, também há espaço para a abordagem grupal, com o Serviço Social de Grupo, cujo enfoque de ambos é a solução dos problemas pessoais, de relacionamento e de socialização. Só nos anos 60, o Serviço Social no Brasil amplia seu campo de atuação para o chamado Serviço Social de Comunidade, legitimando com esta forma de intervenção o atendimento do projeto de influência norte-americano.

No período pós Segunda Guerra Mundial, a profissão que antes era composta quase que exclusivamente por elementos da elite, passa a receber agentes que procediam da pequena burguesia, não mais movidos apenas por motivações religiosas, mas incentivados e interessados pela qualificação profissional que poderia garantir acesso ao mercado de trabalho.

Em 1942, a era Vargas possibilitou estreitar relações com os Estados Unidos, em nome de interesses econômicos e políticos cujo principal objetivo era fortalecer o capitalismo na América Latina e combater o comunismo. Esta relação estendeu-se para além das relações econômicas e envolveu um forte processo de ideologização norte-americana no País. A América do Norte passa a ser o novo 
"protótipo" de ideias, a nova referência de ações, especialmente na esfera das políticas públicas.

O Serviço Social, inserido neste contexto social, sofre forte rebatimento da ideologia da época e passa a buscar no modelo de profissão norte-americano uma nova referência filosófica, o suporte teórico e científico necessário para responder às demandas postas ao exercício profissional. O ideário dominante requeria uma crescente intervenção técnica (organizada e planejada) e fazia que o Serviço Social desencadeasse uma busca de recursos técnicos para superar ações espontâneas e filantrópicas. As exigências de tecnificação do Serviço Social são atendidas, mantendo-se a mesma razão instrumental: busca-se uma maior qualificação dos procedimentos interventivos, utilizando-se, inclusive, fundamentos advindos da Psicologia, na expectativa de que os profissionais, assistentes sociais fossem capazes de executar programas sociais com soluções consideradas modernizantes para o modelo desenvolvimentista adotado no Brasil.

Esse é um período importante para consolidação da profissão, pois ela se estabelece de forma significativa no âmago das instituições públicas e privadas. As escolas de formação profissional multiplicam-se, "ao final da II Guerra Mundial já se encontravam em funcionamento cerca de duzentas escolas distribuídas pela Europa, pelos Estados Unidos e pela América Latina, onde se instalaram a partir de 1925" (Martinelli, 2000, p.108). O Serviço Social com sua formação teórico-metodológica sustentava as ações "modernizadoras", pois respondia de forma particular às necessidades e exigências determinadas pelo capital. Os assistentes sociais começam a assumir, no mercado de trabalho, funções de coordenação e de planejamento de programas sociais.

A ação profissional tem por objetivo, orientada pela matriz positivista, eliminar os "desajustes sociais" por meio de uma intervenção moralizadora de caráter individualizado e psicologizante, revelando uma ideia e imagem falsas de reforma social. O conservadorismo continua presente no universo ideológico da profissão e passa a conceber uma política técnico-burocrática a partir desse período. E como expressa Barroco (2003, p.96), o Serviço Social traduz sua ação 
profissional por meio, de uma ética vinculada à moral conservadora e dogmática segundo a base ideológica neotomista:

os "problemas sociais" são concebidos como um conjunto de "disfunções sociais", julgados moralmente segundo uma concepção de "normalidade" dada pelos valores cristãos. A tendência ao "ajustamento social", a psicologização da questão social, transforma as demandas por direitos sociais em "patologias"; com isso, o Serviço Social deixa de viabilizar o que eticamenteé de sua responsabilidade: atender às necessidades dos usuários, realizar objetivamente seus direitos. (idem, p.94)

A abordagem individualizada, com predominância de uma ação psicologizada, ainda era a mais utilizada pelo Serviço Social, caracterizada pela perspectiva de responsabilização do indivíduo com seu destino social, embora alguns segmentos profissionais estivessem atuando em planejamentos e ações de maior amplitude.

Em meados de 1960, surge um momento importante no desenvolvimento do Serviço Social como profissão. É a primeira crise ideológica em algumas escolas de Serviço Social, com o aparecimento, na América Latina, da proposta de transformação da sociedade, em substituição à desenvolvimentista adotada até o momento. Nessa década, o mundo passa por grandes transformações, especialmente na América Latina, com a Revolução Cubana que, criticando as estruturas capitalistas, mostra-se ao continente como alternativa de desenvolvimento, libertando-se dos Estados Unidos. É grande o inconformismo popular com o modelo de desenvolvimento urbano industrial dominante.

Toda essa agitação política é acompanhada pelas reflexões e pela inquietação das ciências sociais que, por meio da introdução do marxismo, começam a questionar a dependência externa, especialmente a norte-americana, por meio do enfoque dialético.

Essa crise não poderia deixar de atingir as Universidades e, especialmente, o Serviço Social que começa a questionar sua ação, conforme apresenta Netto (2001, p.128): 
Trata-se de um cenário, em primeiro lugar, completamente distinto daquele em que se moveu a profissão até meados dos anos sessenta. Sem entrar na complexa causalidade que subjazia ao quadro anterior da profissão, é inconteste que o Serviço social no Brasil, até a primeira metade da década de sessenta, não apresentava polêmicas de relevo, mostrava uma relativa homogeneidade nas suas projeções interventivas, sugeria uma grande unidade nas suas propostas profissionais, sinalizava uma formal assepsia de participação político-partidária, carecia de uma elaboração teórica significativa e plasmava-se numa categoria profissional onde parecia imperar, sem disputas de vulto, uma consensual direção interventiva e cívica:

Assim o Serviço Social começa a perceber a dimensão política de sua prática, e o modelo vigente baseado na visão funcionalista do indivíduo e com funções integradoras não é mais de interesse da realidade latino-americana que passava por transformações sociais, políticas e econômicas. O modelo importado de Serviço Social torna-se inoperante e tem início um processo de ruptura teórico-metodológico, prático e ideológico. "A ruptura com o Serviço Social tradicional se inscreve na dinâmica de rompimento das amarras imperialistas, de luta pela libertação nacional e de transformações da estrutura capitalista excludente, concentradora, exploradora" (Faleiros, 1987, p.51).

Nos anos posteriores, a profissão busca uma concepção crítica e um vínculo com a classe trabalhadora, embasado em uma percepção do exercício profissional para além da mera razão instrumental, ou seja, a busca de uma "transformação na intencionalidade dos profissionais que se identificavam como agentes de mudanças" (Barroco, 2003, p.108).

Na década de 1960, o modelo de desenvolvimento entra em crise, provocando uma agitação política e muitas mobilizações populares, e, o Serviço Social é influenciado por este clima político, quando dá início a um processo de discussão política no interior da categoria.

É necessário, portanto, buscar caminhos e que aconteçam, no interior da categoria, reflexões, como apresenta Netto (2001, p.146): 
indagando-se sobre o papel dos profissionais em face de manifestações da "questão social", interrogando-se sobre a adequação dos procedimentos profissionais consagrados às realidades regionais e nacionais, questionando-se sobre a eficácia das ações profissionais e sobre a eficiência e legitimidade das suas representações, inquietando-se com o relacionamento da profissão com os novos atores que emergiam na cena política (fundamentalmente ligados às classes subalternas) e tudo isso sob o peso do colapso dos pactos políticos que vinham do pós-guerra, do surgimento de novos protagonistas sociopolíticos, da revolução cubana, do incipiente reformismo gênero Aliança para o Progresso, ao mover-se assim, os assistentes sociais latino-americanos, através de seus segmentos de vanguarda, estavam minando as bases tradicionais da sua profissão.

Assim, em plena vigência da Ditadura Militar, instaurada no País desde os anos de 1964, é que o Serviço Social vai passar por processo de renovação amplo que mudará de forma significativa sua base teórico-conceitual.

Confirma Faleiros (2005, p.26):

A mobilização social e política da sociedade e a mobilização interna dos assistentes sociais põem em relevo a crise da profissão em meados dos anos 60: sua desqualificação no mundo científicoacadêmico, sua inadequação "metodológica" com a divisão em serviço social de caso, serviço social de grupo e desenvolvimento de comunidade e a ausência de uma teorização articulada. Suas práticas mais significativas faziam-se longe dos graves problemas sociais, sem consonância com as necessidades concretas do povo. As ações de transformação ficavam "à margem".

O Movimento de Reconceituação do Serviço Social, iniciado na década de 1960, representou uma tomada de consciência crítica e política dos assistentes sociais em toda a América Latina, não obstante, no Brasil as condições políticas em que ele ocorreu trouxe elementos muito diversos dos traçados em outros países. As restrições 
da Ditadura Militar, principalmente depois do Ato Institucional $\mathrm{n}^{\circ}$ 5 (Barros, 1997, p.42), trouxeram elementos importantes nos rumos tomados pelo Serviço Social em seu processo de renovação. Esses profissionais, mediante o reconhecimento de intensas contradições ocorridas no exercício profissional, que se apoiava na corrente filosófica positivista, de Augusto Comte, questionavam seu papel na sociedade, buscando levar a profissão a romper com a alienação ideológica a que se submetera. Suas expectativas e desejos voltavamse para a busca da identidade profissional do Serviço Social e sua legitimação no mundo capitalista. Para tanto, uma nova proposta teórico-ideológica deveria alicerçar o ensino da profissão, originando uma prática não assistencialista, mas transformadora, comprometida com as classes populares. Quando o modelo filosófico elaborado por Karl Marx, passou a embasar o referencial teórico-metodológico do Serviço Social, o chamado materialismo Histórico Dialético. É no marco desse movimento que o Serviço Social, abertamente, apropriase da tradição marxista e o pensamento de raiz marxiana deixou de ser estranho no universo profissional (Netto, 2001, p.148).

Nesse modelo, o referencial teórico-científico é o Materialismo Histórico e o referencial filosófico e a Lógica Dialética (ou a dialética materialista), que tem por objetivo estudar as relações que envolvem homem e sociedade, ou seja, a prática concreta, afirmando que, nesta interação, há uma constante transformação, com crescimento quantitativo e qualitativo.

O Materialismo Histórico Dialético situa a sociedade determinada historicamente e em constante transformação, dividida em classes sociais distintas: a burguesia, como detentora do capital e de todo o lucro, e a classe trabalhadora ou o proletariado que dispõe da força de trabalho vendida por um ínfimo salário, não garantindo condições dignas de sobrevivência.

Assim, como afirma José Filho (2002, p.57), que o Serviço Social,

no decorrer das últimas décadas, evoluiu no processo de pensar-se a si mesmo e à sociedade, produzindo novas concepções e autorrepresentações como "técnica social", "ação social modernizante" 
e posteriormente "processo político transformador. Atualmente põe ênfase nas problematizações da cidadania, das políticas sociais em geral e, particularmente, na assistência social.

Netto (2001, p.151-64) apresenta três vertentes que se fizeram presentes no processo de renovação do Serviço Social no Brasil e instauraram o ecletismo ou o pluralismo profissional: a tendência modernizadora, a reatualização do conservadorismo e a intenção de ruptura.

A vertente modernizadora teve hegemonia até os anos 70, iniciando-se no Seminário de Araxá em 1967 e se consolidando no Seminário de Teresópolis em 1970. Buscou modernizar o Serviço Social a partir da mesma razão instrumental vigente na profissão (neopositivismo), com isso, faz a revisão de métodos e técnicas para adequar-se às novas exigências postas pelo contexto. O Serviço Social é tido como elemento dinamizador e integrador do processo de desenvolvimento.

A vertente da reatualização do conservadorismo (ou fenomenológica) buscou desenvolver procedimentos diferenciados para a ação profissional, a partir do que seus teóricos conceberam como referencial fenomenológico. Esta vertente recupera o que há de mais conservador na herança profissional, com um enfoque psicologizante das relações sociais e distante do verdadeiro legado fenomenológico de Husserl.

Segundo Barroco (2003, p.138):

A fenomenologia se apresenta como um método de ajuda psicossocial fundado na valorização do diálogo e do relacionamento; com isso, reatualiza a forma mais tradicional de atuação profissional: a perpectiva psicologizante da origem da profissão. [...] e o marco referencial teórico dessa metodologia é constituído por três grandes conceitos: diálogo, pessoa e transformação social.

A terceira vertente do movimento de reconceituação nos anos 80 foi a marxista, denominada de intenção de ruptura com o Serviço Social tradicional (Netto, 2001, p.247). Por meio de um pequeno grupo 
de vanguarda, essa perspectiva remeteu a profissão à consciência de sua inserção na sociedade de classes, gerou um inconformismo tanto em relação à fundamentação teórica quanto à prática, fazendo emergir momentos de debates e questionamentos que se estendem não exclusivamente ao que ocorre dentro da profissão, mas principalmente sobre as mudanças políticas, econômicas, culturais e sociais que a sociedade da época enfrentava, consequência do desenvolvimento do capitalismo mundial que impôs à América Latina seu modelo de dominação, da exploração e da exclusão.

Essa vertente de ruptura não ocorreu sem problemas, pois estes relacionam-se à visão reducionista e equivocada do marxismo presente no marxismo althusseriano (Louis Althusser), que recusou a via institucional e as determinações sócio-históricas da profissão, (Yazbek, 2000, p.25), porém tais problemas não serão aqui detalhados. Tal vertente adquire maior consistência, quando surgem os estudos que procuram aprofundar as formulações teóricas da profissão. Fundamentadas nessa nova perspectiva, especialmente no que se refere à dimensão político-ideológica, explicitam o caráter contraditório de sua prática e vinculam sua ação profissional à transformação social.

Essas tendências, que expressam matrizes diferenciadas de fundamentação teórico-metodológicas da profissão, acompanharam a trajetória do pensamento e da ação profissional nos anos seguintes. É nos anos 80 (séc. XX) que a teoria social de Marx inicia sua efetiva interlocução com a profissão. Outras estratégias passam a compor a prática profissional: educação popular, assessoria a setores populares, investigação e ação e principalmente a redefinição da prática da Assistência Social.

É no bojo deste debate que o Serviço Social consegue, ao longo dos últimos 30 anos, ir definindo uma concepção mais crítica de sua própria inserção no mundo do trabalho, como especialização do trabalho coletivo. E será esse referencial marxista que,

a partir dos anos 80 e avançando nos anos 90, irá imprimir direção ao pensamento e à ação do Serviço Social no Brasil. Permeará as ações 
voltadas à formação de assistentes sociais na sociedade brasileira (o currículo de 1982 e as atuais diretrizes curriculares); os eventos acadêmicos e aqueles resultantes da experiência associativa dos profissionais, como suas convenções, congressos, encontros e seminários; estará presente na regulamentação legal do exercício profissional e em seu Código de Ética. (Yazbek, 2000, p.26)

Essa realidade ganha visibilidade possibilitando um novo processo de recriação da profissão, "em busca de sua ruptura com o histórico conservadorismo e do avanço da produção de conhecimento, nos quais a tradição marxista aparece hegemonicamente como uma das referências básicas" (idem, ibidem).

Obviamente que esse percurso da profissão não aconteceu sem dificuldades, limites e desafios, pois inicialmente a apropriação equivocada do referencial teórico fez que o Serviço Social negasse a dimensão instrumental da profissão e mesmo a atuação no âmbito do Estado. Mais tarde, com o retorno às fontes do pensamento de Marx, a perspectiva dialética pôde ir subsidiando uma análise de realidade mais coerente, possibilitando a apreensão das mediações necessárias para uma análise em uma perspectiva de totalidade. Com isso, o Serviço Social foi construindo seu projeto ético-político que possibilita uma nova perspectiva em sua dimensão interventiva.

Na década de 1990, as consequências da lógica capitalista excludente e destrutiva, desenhadas no modelo de globalização neoliberal, contribuem para a precarização e a subalternização do trabalho à ordem do mercado, para a desmontagem dos direitos sociais, civis e econômicos, para a eliminação da estrutura e responsabilidade do Estado em face da "questão social, para a privatização dos serviços públicos e empresas estatais e atingem diretamente a população trabalhadora, rebatendo nos profissionais de Serviço Social enquanto cidadãos trabalhadores assalariados e viabilizadores de direitos sociais.

A profissão, como especialização do trabalho coletivo, traz em si as contradições e as determinações do contexto social mais amplo possibilitando a superação do caráter conservador do Serviço Social, 
que expressa uma visão mecanicista da profissão e da perspectiva que lhe atribuía um caráter revolucionário, fruto de um militantismo que superestimava a capacidade profissional (Barroco, 2003, p.109). É o grande debate entre a postura fatalista e a messiânica, que tanto incomodou os profissionais de Serviço Social. A primeira desconsiderava as contradições do sistema, das instituições e das próprias relações sociais, não sendo possível fazer nada para ser modificado, e a segunda subestimava o contexto social, as classes sociais, as organizações políticas, os movimentos sociais, os homens como sujeitos históricos, enfim, os limites da realidade social e do profissional (Iamamoto, 2001, p.21-2).

No exercício profissional cotidiano, o Serviço Social mantém o desafio de conhecer e interpretar algumas lógicas do capitalismo contemporâneo, especialmente em relação às mudanças no mundo do trabalho e sobre as questões de desestruturação dos sistemas de proteção social e das políticas sociais em geral. E como afirma Iamamoto (2000, p.113), ao profissional assistente social apresenta-se um dos maiores desafios nos dias atuais:

desenvolver sua capacidade de decifrar a realidade e construir propostas de trabalho criativas e capazes de preservar e efetivar direitos, a partir de demandas emergentes no cotidiano. O perfil predominante do assistente social historicamente é o de um profissional que implementa políticas sociais e atua na relação direta com a população usuária. Hoje exige-se um trabalhador qualificado na esfera da execução, mas também na formulação e gestão de políticas sociais, públicas e empresariais: um profissional propositivo, com a sólida formação ética, capaz de contribuir ao esclarecimento dos direitos sociais e dos meios de exercê-los, dotado de uma ampla bagagem de informação, permanentemente atualizada, para se situar em um mundo globalizado.

Mediante essa afirmação da autora, no desenho do perfil do profissional de Serviço Social, como coparticipante do processo de transformação, deverá contribuir, por meio de uma práxis educativa 
e transformadora, para a construção de sujeitos históricos respeitados e valorizados como seres humanos livres capazes de pensar, agir, decidir, optar e, nessa perspectiva dialética, transformar a realidade e por ela ser transformado.

Dessa forma, o exercício da profissão envolve a ação de um sujeito profissional que tem competência para propor, para negociar com a instituição seus projetos, defender seu campo de trabalho, suas qualificações e funções profissionais que extrapolem ações rotineiras e decifrem realidades subjacentes, revertendo-as em ações concretas de benefícios à população excluída. Suas ações vão desde a relação direta com a população até o nível do planejamento, tendo inclusive a árdua tarefa de priorizar os que têm e os que não têm direitos de acesso aos serviços e equipamentos sociais.

Diante do legado histórico da profissão, pode-se ressaltar o protagonismo crescente dos assistentes sociais na prestação de serviços sociais, no campo do planejamento, da gestão e execução das políticas, dos programas, dos projetos e serviços socioassistenciais, no avanço da área acadêmica, na avaliação do processo de formação profissional, na área da pesquisa, na área de produção de conhecimento e na própria organização política da categoria. O Serviço Social aparece atualmente como uma profissão consolidada na sociedade brasileira, ganhando visibilidade no cenário atual e sustentado por um projeto ético-político que o habilita a formular respostas profissionais qualificadas face à questão social. Esse projeto comprometido com valores e princípios que apontam para a autonomia, a emancipação, a defesa da liberdade e da equidade, a socialização da política e da riqueza socialmente produzida e o pleno desenvolvimento de seus usuários, vem se concretizando nas ações cotidianas de trabalho dos Assistentes Sociais, seja qual for o espaço de atuação, permitindo-lhes compreender o Serviço Social na divisão sociotécnica do trabalho e no encaminhamento de ações que contribuam para a ultrapassagem do discurso da "denúncia" para o âmbito das práticas institucionais e da contribuição à formulação de novas políticas sociais.

A efetivação do projeto ético-político do Serviço Social exige que os profissionais, cada vez mais, recriem seu perfil profissional e sua 
identidade, ultrapassem limites institucionais e superem a ideologia do assistencialismo e avancem nas lutas pelos direitos e pela cidadania. É o que será discutido no próximo item.

\section{O Serviço Social e a consolidação do projeto ético-político frente às desigualdades sociais do século XXI}

A partir dos anos 80 , as mudanças ocorridas na profissão foram pautadas na necessidade de conhecer e acompanhar as transformações econômicas, políticas e sociais do mundo contemporâneo e da própria conjuntura do Estado e do Brasil. As duas últimas décadas do século XX foram determinantes nos novos rumos acadêmicos, políticos e profissionais para o Serviço Social. No País, as intensas e crescentes manifestações de expressões da questão social, decorrentes das inúmeras crises econômicas e políticas, exigiram da profissão sua adequação a essas demandas sociais. Esse período marca profundamente no País o desenvolvimento da profissão por meio de um dos seus momentos importantes que é a recusa e a crítica do conservadorismo profissional.

Foi implantado, na década de 1990, o Projeto Ético-Político do Serviço Social, fruto de uma organização coletiva e de uma busca de maturidade que possibilita à profissão a formular respostas qualificadas frente à questão social. Trata-se de um projeto que, para Neto (2000, p.104), é um “[...] processo em contínuos desdobramentos, flexível, contudo sem descaracterizar seus eixos fundamentais". Ele é comprometido com valores e princípios que têm em seu núcleo o reconhecimento da liberdade como possibilidade de escolher concretamente alternativas de vida, buscando o compromisso com a autonomia, a emancipação, a defesa da equidade, a socialização da política e da riqueza socialmente produzida e o pleno desenvolvimento de seus usuários.

Para Santana (2000, p.80): 
Os assistentes sociais, preocupados com a modernização do País e da profissão, assumem posições predominantemente favoráveis à reprodução das relações sociais. Porém, a partir da década de 1980, os setores críticos (em geral, respaldados na teoria marxista) assumem a vanguarda da profissão. É no bojo desse processo de renovação do Serviço Social que o pluralismo se institui e inicia a construção do que hoje chamamos de projeto ético-politico da profissão.

A construção coletiva desse projeto profissional aglutinou assistentes sociais de todos os segmentos e materializou-se no Código de Ética Profissional do Assistente Social, aprovado em 13/3/1993, na Lei de Regulamentação da Profissão de Serviço Social (Lei 8.662 de 7/6/1993) e na proposta das Diretrizes Curriculares para a Formação Profissional em Serviço Social (8/11/1996).

Confirma Guerra (2007, p.37) que:

A década de 1990 confere maturidade teórica ao Projeto Ético Político Profissional do Serviço Social brasileiro que, no legado marxiano e na tradição marxista, apresenta sua referência teórica hegemônica. Enfeixa um conjunto de leis e de regulamentações que dão sustentabilidade institucional, legal, ao projeto de profissão nos marcos do processo de ruptura com o conservadorismo: a) o Novo Código de Ética Profissional de 1993; b) a nova Lei de Regulamentação da Profissão em 1993; c) as Diretrizes Curriculares dos cursos de Serviço Social em 1996; d) as legislações sociais que referenciam o exercício profissional e vinculam-se à garantia de direitos como: o Estatuto da Criança e do Adolescente - ECA de 1990, a Lei Orgânica da Assistência Social - Loas de 1993, a Lei Orgânica da Saúde em 1990.

Esse projeto de profissão é expressão de um momento histórico e fruto de um amplo movimento de lutas pela democratização da sociedade brasileira, com forte presença das lutas operárias que impulsionaram a crise da ditadura, "coroando esforços coletivos e a politização progressista da vanguarda da categoria” (Netto, 1996, 
p.108). A categoria dos assistentes sociais foi sendo questionada pela prática política de diferentes segmentos da sociedade civil, no contexto do crescimento dos movimentos sociais e das lutas em torno da elaboração e aprovação da Carta Constitucional de 1988 e pela defesa do Estado de Direito, não ficando como mera expectadora dos acontecimentos. Mas avançou com maturidade sendo protagonista na construção desses momentos históricos e em sua participação efetiva em gerir políticas sociais e viabilizar a construção dos direitos sociais das classes subalternizadas da sociedade, conquistando o que Netto (idem, ibidem) denominou, "maturação profissional".

É possível atestar que a profissão nas últimas décadas deu um salto qualitativo em sua formação acadêmica e em sua presença política na sociedade. Intensificou-se a produção científica e o mercado editorial; os assistentes sociais constituíram-se uma categoria pesquisadora, reconhecida nacional e internacionalmente (tema do próximo item). E ainda amadureceram em suas representações políticas e corporativas, por meio de órgãos acadêmicos e profissionais reconhecidos e legitimados. Travou-se um amplo debate em torno das políticas sociais públicas, especialmente da seguridade social, contribuindo para a reafirmação da identidade profissional.

A profissão, como afirma Yazbek (2000, p.29), enfrenta o desafio de decifrar algumas lógicas do capitalismo contemporâneo, especialmente em relação às mudanças no mundo do trabalho, os processos desestruturadores dos sistemas de proteção social e da política social em geral e o aumento da pobreza e a exclusão social. O Serviço Social vê-se confrontado e desafiado a compreender e intervir nessa sociedade de transformações configuradas nas novas expressões da questão social: a precarização do trabalho, a penalização dos trabalhadores, o desemprego, a violência em suas várias faces, a discriminação de gênero e etnia e tantas outras questões relativas à exclusão.

Como observa Barroco (2003, p.180),

se na entrada dos anos 90 é evidente o amadurecimento de um "vetor de ruptura", isso não significa que essa vertente tenha alcançado uma "nova legitimidade" junto às classes subalternas. Além disso, 
a ruptura com o conservadorismo profissional, consolidada em 80 , não significa que o conservadorismo (e com ele o reacionarismo) foi superado no interior da categoria.

Nesse cenário, no início da década de 1990, é que a questão ética apresentava-se como tema relevante para a profissão. Surgiram as mobilizações reivindicatórias da ética na política e como tema privilegiado de cursos, encontros, publicações, invadem os meios de comunicação de massa atingindo a vida cotidiana da população. E para a profissão, apareceram desafios e questionamentos teóricopráticos e ético-políticos para o enfrentamento das consequências do ideário neoliberal que acirravam as desigualdades sociais.

A profissão passou a explicitar com maior clareza seu projeto ético-político que foi gestado em duas décadas anteriores. Essa construção caracterizou-se pela busca do rompimento com a vertente conservadora do Serviço Social e pela proposição de um novo projeto profissional que se aproxima dos projetos societários.

Segundo Netto (2000, p.94), "os projetos societários são projetos coletivos; mas seu traço peculiar reside no fato de se constituírem projetos macroscópicos, em propostas para o conjunto da sociedade".

Com isso, o projeto ético-político do Serviço Social caracteriza-se pelos determinantes sócio-históricos, pela dimensão política pautada no compromisso com a classe trabalhadora e pelos interesses, aspirações e demandas do projeto coletivo dos assistentes sociais.

Então, a categoria com a aprovação do Código de Ética em 1993, conseguiu articular compromissos éticos, políticos e o exercício da prática profissional, reconhecendo as mediações necessárias entre projeto societário e projeto profissional.

Para os projetos profissionais, Netto (2000, p.95) apresenta como construção coletiva de uma categoria, (ou sujeito coletivo) que retrata sua imagem profissional:

Os projetos profissionais apresentam a autoimagem de uma profissão, elegem os valores que a legitimam socialmente, delimitam e priorizam os seus objetivos e funções, formulam os requisitos 
(teóricos, institucionais e práticos) para seu exercício, prescrevem normas para o comportamento dos profissionais e estabelecem as balizas da sua relação com os usuários de seus serviços, com as outras profissões e com as organizações e instituições sociais, privadas e públicas (entre estas, também e destacadamente com o Estado, ao qual coube, historicamente, o reconhecimento jurídico dos estatutos profissionais).

Nesse sentido, a formulação de um projeto profissional crítico à sociedade capitalista é "uma demanda dos segmentos da sociedade que recebem os serviços prestados pelo assistente social, e não apenas uma condição de grupos ou do coletivo profissional" (Guerra, 2007, p.9).

Este projeto profissional reafirma o compromisso da categoria com um projeto societário que propõe a construção de uma nova ordem societária, sem dominação, exploração de classe, etnia e gênero. Ele tem como aspecto central a liberdade, ou seja, a possibilidade de o ser humano fazer concretamente suas escolhas, e com isso comprometer-se com a autonomia, a emancipação e a plena expansão dos indivíduos. A partir desses princípios, o projeto ratifica a intransigente defesa dos direitos humanos e contra qualquer forma de preconceito, o arbítrio, o autoritarismo, culminando no exercício do pluralismo na sociedade em geral e no exercício profissional (Netto, 2000, p.104-5).

Como analisa o autor (idem, p.105), a dimensão política do projeto é evidenciada pela equidade e pela justiça social, por meio da busca universal do acesso aos bens e aos serviços nos programas e nas políticas sociais. Com isso, tem-se a consolidação da cidadania por meio da viabilização de todo esse processo democrático, garantido a todas as classes trabalhadoras.

A efetivação desses valores preconizados pelo projeto-ético político do Serviço Social ocorrerá por meio do protagonismo da classe trabalhadora na inserção e na participação nos espaços públicos, com poderes de decisão no que lhe diz respeito, na ampliação do conhecimento de direitos e interesses em jogo, da viabilização de meios para a implementação de decisões coletivas, do acesso às regras 
de negociação com transparência, e com isso o trabalhador social, possa contribuir para a inclusão social da classe trabalhadora na real construção da cidadania e no fortalecimento da democracia. Assim, Iamamoto (2000, p.126) explica:

Uma aproximação, por meio da pesquisa criteriosa, às condições de vida e de trabalho das classes subalternas é um requisito indispensável para a efetivação daqueles valores e princípios mencionados. Esta aproximação deve permitir captar interesses e necessidades em suas diversas maneiras de explicitação, englobando formas diferenciadas de organização e luta para fazer frente à pobreza e à exclusão econômica, social e cultural. Formas de lutas que passam por partidos políticos, sindicatos e movimentos sociais organizados; mas que passam, também, por reivindicações em torno de melhorias parciais de vida, além do conjunto de expressões associativas e culturais que conformam o modo de viver e de pensar das classes e seus segmentos sociais. O desafio é captar os núcleos de contestação e resistência, as formas de imaginação e intervenção do cotidiano, de defesa da vida e da dignidade do trabalhador.

Esse compromisso ético-político assumido pela categoria nas últimas décadas, tem revelado o desafio da competência profissional, que deve embasar-se no aprimoramento intelectual do assistente social, com ênfase em uma "formação acadêmica qualificada, alicerçada em concepções teórico-metodológicas críticas e sólidas, capazes de viabilizar uma análise concreta da realidade social" e possibilitar um processo de formação permanente e "estimular uma constante postura investigativa” (Netto, 2000, p.105).

No que diz respeito aos usuários dos serviços, faz-se necessário que este projeto profissional priorize uma nova relação de compromisso com a qualidade dos serviços prestados à população, bem como a publicização, democratização e universalização dos recursos institucionais a ela direcionados.

Contudo, a consolidação desse projeto depende da organização da categoria dos assistentes sociais e de sua articulação com outras 
categorias que partilhe dos mesmos compromissos e princípios fundamentais. Depende ainda da mobilização que se trave com a sociedade civil na luta pela garantia dos direitos civis, sociais e políticos de todos os cidadãos. Requer, segundo Iamamoto (2001, p.141) "remar na contracorrente, andar no contravento, alinhando forças que impulsionem mudanças na rota dos ventos e das marés na vida em sociedade". Trata-se de um projeto que está se consolidando hegemônico no interior da categoria, isto porque, ele tem raízes efetivas na vida social brasileira, vinculando-se a um projeto societário antagônico ao das classes possuidoras e exploradoras, como explica Netto (2000, p.106):

Neste sentido, a construção deste projeto profissional acompanha a curva ascendente do movimento democrático e popular que, progressista e positivamente, tensionou a sociedade brasileira entre a derrota da ditadura e a promulgação da Constituição de 1988 (referida como Constituição Cidadã), um movimento democrático e popular que, colocando-se inclusive como alternativa nacional de governo nas eleições presidenciais de 1989, forçou uma rápida redefinição do projeto societário das classes possuidoras.

Na contramão da busca pela efetivação do projeto ético-político do Serviço Social, existem duras ameaças de mudanças estruturais propostas pelo capital e obviamente opostas aos princípios do projeto profissional. O neoliberalismo instituiu uma política de desmantelamento do Estado, privatização das instituições públicas, precarização de direitos e garantias sociais e a sobreposição do econômico em relação ao social ou às expressões da questão social e consequente aviltamento da pessoa humana.

É importante considerar que o aprofundamento e a manutenção do projeto ético-político do Serviço Social na contemporaneidade, em tempos de tantas adversidades, depende da vontade majoritária da categoria profissional e junto a ela, o revigoramento das lutas e movimentos democráticos e populares, garantindo os direitos a programas e a políticas sociais estabelecidas pelas conquistas das classes trabalhadoras. Junto a isso, afirma Santana (2000, p.90) que 
a relevância do processo formativo, torna-se um determinante para a consecução do projeto ético-político da profissão. Explica que:

À medida que o profissional assume o compromisso com a transformação dessa ordem societária e institui como estratégia de ação, no atual momento histórico, a luta por direitos sociais, comprometendose com a qualidade dos serviços prestados e com o fortalecimento do usuário, seu perfil tem que ser necessariamente crítico e questionador. É preciso, também, que este esteja munido de um referencial teórico-metodológico que lhe permita apreender a realidade numa perspectiva de totalidade, e construir mediações entre o exercício profissional comprometido e os limites dados pela realidade de atuação.

O Serviço Social ao longo de sua história, conforme abordado anteriormente, convive com o sistema capitalista, no qual nasceu enquanto profissão, buscou criar estratégias de minimização das manifestações da miséria e empobrecimento da classe trabalhadora, por meio de ações distributivas de serviços assistencialistas e clientelistas, sem questionar as estruturas que geram as desigualdades sociais.

Para a categoria profissional a releitura do trabalho do assistente social exigiu a ruptura com posicionamentos ideológicos e ações restritas, endógenas e focalistas do Serviço Social, transpondo as determinações da classe dominante. Com isso, faz-se necessário um profissional propositivo, reflexivo, crítico, "que aposte no protagonismo dos sujeitos sociais, versado no instrumental técnico-operativo”, com competência para ações profissionais em nível de assessorias, de negociações, de planejamentos, de pesquisa e de incentivo à participação dos usuários em gestão e da avaliação de programas sociais de qualidade (Iamamoto, 2001, p.144).

Continua a mesma autora que, para responder a esse perfil profissional traçado:

Exige uma competência crítica que supere tanto o teoricismo estéril, o pragmatismo, quanto o mero militantismo. Competência que não se confunde com aquela estabelecida pela burocracia da 
organização, conforme a linguagem institucionalmente permitida e autorizada; que não reifica o saber fazer, subordinando-o, antes, à direção social desse mesmo fazer. Competência que contribui para desvelar os traços conservantistas ou tecnocráticos do discurso oficial, recusa o papel de tutela e controle das classes subalternas em seus diferentes segmentos e grupos, para envolvê-las nas teias e amarras do poder econômico, político e cultural. (idem, ibidem)

Nesse sentido, surge um desafio histórico aos assistentes sociais, frente ao sistema vigente, em atingir a "consciência humano-genérica” importante ao exercício crítico da profissão, pois implica em "criar condições para vencer a alienação em um mundo marcado pela reificação social” (Santana, 2000, p.90).

O cenário atual com a idolatria da moeda, o fetiche do mercado e do consumo, o "culto" ao individualismo, a lógica do mercado financeiro, reforça o desafio dos assistentes sociais em manter seu caminho pautado pelos valores e princípios éticos e políticos que iluminaram suas ações durante as últimas décadas. Percebe-se que o profissional de hoje precisa se requalificar, ter visão crítica da realidade, por meio de uma atitude reflexiva, analítica, investigativa e propositiva frente à realidade. Exige-se um profissional ousado, atento e disposto a apropriar-se e a decifrar novas propostas de trabalho apresentadas ao Serviço Social.

Afirma Guerra (2007, p.27) nesse contexto que

os valores e princípios do atual projeto profissional remetem a um novo modo de operar a profissão o que pressupõe a crítica sobre as condições e relações do seu exercício profissional [...] é claro ao profissional que não basta se indignar contra a moral burguesa, não basta o senso moral. É necessário que se desenvolva a consciência moral, que se aproprie da ética como reflexão crítica sobre a moral para se estabelecer quais as escolhas e ações tácitas e estratégicas que nos permitam organizar ações e sujeitos históricos para intervir no processo de democratização da sociedade, visando a uma sociedade justa e equitativa, o que passa pela defesa da vida humana. 
Neste sentido, é possível entender que o profissional social, de posse desse projeto crítico, percebe que as possibilidades de transformação não estão na profissão, mas na própria realidade, na qual, certamente, por meio de uma intervenção profissional competente, poderão se estabelecer devidas mediações entre interesses da classe trabalhadora e da classe dominante. Competência essa que é dinâmica, não estática e adquirida de uma vez por todas, construída social e historicamente e que ultrapasse saberes e conhecimentos, mesmo se constituindo por eles. É fundamental que haja uma intervenção reflexiva e eficaz no sentido de articular dinâmicas de conhecimentos, saberes, habilidades, valores e posturas.

O projeto profissional hegemônico, por sua perspectiva crítica, torna-se um instrumento capaz de permitir aos assistentes sociais uma antevisão da demanda, a captação de processos emergentes e históricos que se configuram e requisitam uma intervenção profissional a curto, médio e longo prazos, o significado social e político da profissão e da intervenção que desenvolve. Tais projetos têm raízes na vida social e respondem aos anseios de setores e forças da sociedade por meio de valores, princípios, estratégias que se reportam a uma sociedade justa, democrática, equânime (Guerra, 2007, p.30).

Assim, o projeto profissional tem de oferecer respostas concretas para uma democracia social, política e econômica, indicando os meios de concretizá-las.

Enfim, é possível admitir que o projeto ético-político do Serviço Social se consolidará a partir do momento em que este clarifique os objetivos da profissão, que com seu referencial teórico-metodológico permita que o profissional faça a crítica ontológica do cotidiano, da ordem burguesa e dos fundamentos conservadores que persistem na profissão, que lance luzes sobre as novas escolhas e orientações para direcionamentos sociais e, assim, o assistente social estará apto a ocupar os diversos espaços institucionais, privados, públicos e profissionais; a questionar critérios de escolha e elegibilidade para o direcionamento de serviços sociais, a democratizar o acesso à informação; a pesquisar e conhecer os sujeitos que demandam as ações profissionais e realizam alianças com eles; a estabelecer compromisso com as denúncias e efetivar o trabalho de organização popular. 


\section{A formação profissional: do ensino à pesquisa}

A década de 1980 foi extremamente importante nas definições de rumos teórico-metodológicos, técnico-acadêmicos e políticos para o Serviço Social. Tem-se hoje um projeto profissional ético-político, construído coletivamente em décadas anteriores, que selou o compromisso da categoria com a universalização dos valores igualitários e democráticos, conforme já apresentado. Os princípios norteadores desse projeto desdobraram-se no Código de Ética do Assistente Social, de 1993, na Lei de Regulamentação da Profissão de Serviço Social - Lei 8662/93 e na nova Proposta de Diretrizes Gerais para o curso de Serviço Social.

O novo Código de Ética Profissional de 1993 é um marco histórico na trajetória do Serviço Social por sua legitimidade teórico-prática alcançada pela categoria profissional.

A partir desse momento de discussão e de construção coletiva, destacam-se na profissão a relevância e o reconhecimento da ética como componente fundamental do projeto profissional que, nos últimos vinte anos, tem construído uma hegemonia na profissão.

Um olhar retrospectivo para as décadas anteriores não deixa dúvidas de que o Serviço Social foi sendo questionado pela prática política de vários movimentos sociais e segmentos da sociedade civil, encontrando aí sua base social de reorientação da profissão nos anos 80. Com isso, a profissão deu um salto de qualidade, de atuação e de formação profissional. Com o novo Código de Ética, ganhou visibilidade pública e maior credibilidade junto à população usuária. Houve também um avanço no mercado editorial e de produção acadêmica impulsionada pela pós-graduação e pela interlocução teórica com áreas conexas de maior tradição na pesquisa social.

Os assistentes sociais ingressaram, na década de 1990, como uma categoria pesquisadora e reconhecida pelos órgãos de fomento à pesquisa.

Tiveram ainda um amadurecimento em suas formas de representatividade político-corporativas, por meio de órgãos de representação acadêmica e profissional reconhecidos e legitimados. E amplas dis- 
cussões e debates em torno das políticas sociais públicas, especialmente a assistência social, como direito social, na teia das relações entre o Estado e a sociedade civil, contribuíram para intensificar e propagar a reflexão e o debate sobre a identidade profissional, na busca do fortalecimento de seu autorreconhecimento e para traçar criticamente os rumos da profissão.

A reforma curricular aprovada em 1979 pela assembleia da Associação Brasileira de Escolas de Serviço Social, implementada a partir de 1982, desmontou a estrutura tradicional dos chamados processos de intervenção em caso, em grupo e em comunidade pela orientação teórico-metodológica da prática profissional pautada nas principais tendências que, até então, embasavam teoricamente o Serviço Social: o funcionalismo, a fenomenologia e o marxismo. Defendeu a profissão na busca de uma visão crítica e comprometida com a transformação social e a formação dos futuros assistentes sociais a partir de análises críticas da realidade capitalista.

A nova reforma do projeto de formação profissional, ocorrida em 1998, foi motivada pela participação e pela mobilização vivenciada na revisão curricular de 1982, fruto do debate coletivo. Sobretudo no meio universitário, buscou a formação de um profissional generalista, em ruptura com as especializações e contribuiu para o avanço do entendimento das debilidades e de suas consequentes inadequações metodológicas do pensar e do fazer profissional, "a prática é formulada como um processo de trabalho, como uma atividade com fins, meios e resultados em torno da questão social, definida formalmente como objeto do Serviço Social" (Faleiros, 2005, p.32).

A partir de então, na década de 1990, a formação profissional passa a ser primordial, e o projeto curricular foi elaborado e aprovado pelos órgãos competentes da categoria, especialmente pela Associação Brasileira de Ensino em Serviço Social (ABESS), com um novo currículo, hoje em vigor. Segundo a ABESS 7 (1997, p.63):

Este currículo traduz, em uma perspectiva histórico-crítica, os seguintes núcleos de fundamentação na constituição da formação profissional: 1. núcleo de fundamentos teórico-metodológicos da 
vida social; 2. núcleo de fundamentos da formação sócio-histórica da sociedade brasileira; 3 . núcleo de fundamentos do trabalho profissional.

Diante dessas mudanças ocorridas no campo da formação profissional, duas características decorrentes desse processo tornaram-se pontos de reflexão e do desenvolvimento da profissão: a preocupação com a investigação como dimensão constitutiva da formação e do exercício profissional e a afirmação das políticas sociais como campo de interesse teórico-prático para os assistentes sociais. Contudo, o processo de implementação do currículo mínimo do Serviço Social, ao longo dos anos, não ocorreu de forma tranquila, mas foi objeto de críticas, de dúvidas e de debates por parte de diferentes segmentos intelectuais e profissionais ligados ao Serviço Social e pelos próprios assistentes sociais, pois muitos deles sentiam-se despreparados e distantes de uma proposta inovadora. Entretanto, não será discutida aqui essa questão, mas o registro dessas informações evidencia os limites da profissão e os permanentes questionamentos da identidade profissional.

Assim afirma Koike (2000, p.107):

As alterações na configuração sociotécnica da profissão evidenciam ser a formação profissional um processo dinâmico, continuado, inconcluso, em permanente exigência de apropriação e desenvolvimento dos referenciais críticos de análise e dos modos de atuação na realidade social. E o ato de avaliar a profissão (formação e trabalho profissionais) em suas conexões com as necessidades sociais de onde derivam as demandas ao Serviço Social, expõe com radicalidade as exigências de uma profunda, cuidadosa e continuada capacitação profissional. Essa radicalidade marcou o processo de construção das novas diretrizes curriculares que se inicia com a definição dos critérios norteadores do trabalho coletivo.

Para Iamamoto (2001, p.52), diante dos avanços qualitativos que o Serviço Social viveu nas últimas décadas, no que diz respeito 
à formação profissional e ao trabalho de Serviço Social, travaram-se fortes embates e discussões no que diz respeito à relação dialética entre teoria e exercício profissional (prática) ou seja, a busca de estratégias do profissional que vão mediar as bases teóricas acumuladas com a operatividade do trabalho profissional. O caminho é longo, mas foi dado um longo "voo teórico", aproximando o Serviço Social ao movimento da realidade concreta, às várias expressões da questão social. O desafio na atualidade, segundo a autora, "é transitar da bagagem teórica acumulada ao enraizamento da profissão na realidade, atribuindo, ao mesmo tempo, uma maior atenção às estratégias, táticas e técnicas do trabalho profissional", em decorrência das particularidades dos temas que são objetos de estudo e de ação do profissional.

Nesse contexto, situa-se o mundo da pesquisa científica que a categoria profissional enveredou nas décadas passadas, e fortalecese, nos dias atuais, a aproximação do profissional e o científico, do profissional e do político e do profissional com as condições e relações de trabalho (Faleiros, 2005, p.28). Herdeira da ditadura militar e de seu projeto de modernização conservadora, a categoria dos assistentes sociais emerge na cena social no processo de "transição democrática" com um novo perfil acadêmico-profissional, que representa um salto de qualidade na trajetória do desenvolvimento profissional (Iamamoto, 1998, p.103).

O Serviço Social insere-se, nos anos da ditadura, nos quadros universitários, passando a formação profissional a ser paulatinamente articulada à pesquisa e à extensão.

A profissão implementa nos anos 70 e 80 (século XX) a pósgraduação em Serviço Social com os cursos lato sensu e strictu sensu, rapidamente ampliados, tendo nesse período a consolidação acadêmica do ensino pós-graduado nos cursos de especialização, no nível de mestrado (nos anos de 1970, a existência de seis cursos de mestrado) e com desdobramentos no nível de doutoramento, atualmente todos ampliados e com intercâmbio nacional e internacional.

Hoje, no Brasil, é possível reconhecer a credibilidade científica que o Serviço Social veio conquistando junto aos órgãos oficiais de 
fomento à pesquisa $\mathrm{e} o$ apoio, o incentivo e o trabalho de seus órgãos competentes, especialmente a ABEPSS (2004, p.78) que

Reafirma seu empenho em contribuir no sentido de que a formação da graduação e pós-graduação em Serviço Social substancie e respalde cada vez mais a plataforma emancipatória da profissão, na resistência às mais diversas formas de exclusão, opressão e violências que no tempo presente se adensam e atualizam como demanda privilegiada ao ensino de qualidade e à pesquisa no Serviço Social.

Diante dessa realidade apresentada, surge como desafio à formação profissional o ideário neoliberal, que busca como ação predominante o enfraquecimento das lutas das classes sociais e sua subordinação ao capital. Tal ideologia é fortalecida especialmente pela "queda do socialismo real e com o florescimento da pós-modernidade, sobretudo em sua versão neoconservadora, influenciando muitos docentes, pesquisadores e pensadores do meio acadêmico levando muitos a desistirem e reverem seus trabalhos" (Koike, 2000, p.114).

Outro aspecto a ser considerado é a concepção de educação para o século XXI, por organismos internacionais como o Fundo Monetário Internacional - FMI e o Banco Mundial, para responderem aos interesses econômicos da globalização; é ainda depositada a tarefa de oferecer soluções aos problemas do desemprego, das lutas étnicas, da violência, do meio ambiente e da própria exclusão, que se apresentam na atualidade.

Enfim, para a educação, fica a tarefa conciliadora e pacificadora de conflitos, ou seja, a existência de uma política educacional mundial que não questione a distribuição de riquezas e do poder, mas ofereça reformas e soluções a partir da própria ordem interna do capital. $\mathrm{O}$ que para Koike (idem, p.115), não existe outro enfrentamento, a não ser desvendar a

concepção ilusória de que poderia "humanizar" o capital em sua própria ordem e fazê-lo por meio de uma educação danificada funcional, pragmática e despolitizada e compreender o caráter e o significado 
das transformações sociais em curso, colocando as classes sociais no centro dessa apreensão como condição de atribuir inteligibilidade ao processo social contemporâneo.

Por fim, tem-se uma reforma da educação superior direcionada para a lógica mercantil, na busca dos negócios lucrativos, calcada na adaptação dos perfis profissionais ao novo paradigma da sociedade moderna, no conhecimento tecnológico, por meio da expansão da educação a distância e consequente precarização, especialmente, do ensino público superior público.

À categoria profissional do Serviço Social, fica o desafio de preparar profissionais aptos para lidar com as contradições do presente apresentadas pela ordem neoliberal e pelo neoconservadorismo no conhecimento, e o compromisso com a qualidade na formação que, consequentemente, perpassa todo o trabalho profissional evitando que o Serviço Social fique burocrático, tecnicista, mercantil e "sem vida".

Tal desafio para os assistentes sociais é, portanto, a busca de um posicionamento ético e político que se insurja contra os processos de alienação vinculados à lógica capitalista, impulsionando-os a trabalhar na busca de romper com a dependência, a subordinação, a despolitização, e assim poder manter vivas as forças sociais motivadoras da esperança de uma nova sociedade e da capacidade de luta no cenário social e profissional.

Efetivamente, o Serviço Social pode interferir na construção de direitos sociais e sujeitos políticos contribuindo com movimentos sociais e lutas da categoria como garantia legal da profissão na Política Educacional das três esferas nacionais: União, Estados e Municípios. É o que será trabalhado nos próximos capítulos por meio dos dados documentais (pesquisa documental) e empíricos da pesquisa de campo. 



\section{4 \\ A CONSTRUÇÃO \\ DA PESQUISA DOCUMENTAL: \\ AVANÇOS E DESAFIOS NA ATUAÇÃO \\ do Serviço Social no Campo \\ EDUCACIONAL}

"A mente que se abre a uma nova ideia, ja-
mais voltará ao seu tamanho original".

A. Einstein

\section{Aspectos metodológicos e o contexto da pesquisa}

Segundo Chizzotti (1995, p.11), "a pesquisa investiga o mundo em que o homem vive e o próprio homem”. Contudo, a pesquisa só existe com o apoio de procedimentos metodológicos adequados, que permitam a aproximação ao objeto de estudo.

Para a construção desse estudo investigativo, foram adotados vários procedimentos metodológicos necessários para se obterem respostas aos questionamentos e aos objetivos propostos inicialmente pela pesquisadora: compreender e explicar a importância do Serviço Social na Política Educacional, garantindo o conhecimento técnico-científico de uma equipe interdisciplinar na efetivação da formação de cidadãos.

São apresentados, nesses próximos capítulos, os dados obtidos pela pesquisa documental e de campo orientados durante esse estudo, pela pesquisa bibliográfica. 
Segundo Gil (2002, p.44), “[...] a pesquisa bibliográfica é desenvolvida com base em material já elaborado, constituído principalmente de livros e artigos científicos". A principal vantagem da pesquisa bibliográfica está no fato de permitir ao investigador a cobertura de uma gama de fenômenos muito mais ampla do que aquela que poderia pesquisar diretamente (idem, p.45). Sua finalidade é colocar o pesquisador em contato com o que já se produziu e se registrou a respeito do tema de pesquisa. Tais vantagens revelam o compromisso da qualidade da pesquisa.

Assim, além de permitir o levantamento das pesquisas referentes ao tema estudado, a pesquisa bibliográfica permite ainda o aprofundamento teórico que norteia a pesquisa.

Foram utilizados autores que se fundamentam no referencial crítico-dialético e apresentam reflexões sobre a legitimação da profissão de Serviço Social no cenário brasileiro, sua representatividade no mundo da pesquisa e sua intervenção nos diversos campos sociais, com destaque à política educacional como espaço a ser conquistado.

Como primeiro momento, é realizado um estudo documental dos dados históricos do trabalho desenvolvido pelo Serviço Social na Educação (capítulo 4) e, em seguida, um estudo exploratório e investigativo da realidade, que tem como objetivo "proporcionar maior familiaridade com o problema, com vistas a torná-lo mais explícito ou a construir hipóteses" (Gil, 2002, p.41). Dessa forma, a pesquisa de campo deverá contribuir para a concretização dos objetivos propostos (capítulo 5).

A pesquisa é vista como um diálogo crítico e criativo com a realidade, culminando com a elaboração própria e com a capacidade de intervenção. Em tese, pesquisa é a atitude de "aprender a aprender", e, como tal, faz parte de todo processo educativo e emancipatório (Demo, 2000c, p.128).

Com base em uma abordagem qualitativa, buscar-se-á, segundo Minayo (2000, p.21) respostas a questões particulares que não podem ser quantificadas como o universo de significados, de motivos, de aspirações, de crenças, de valores e atitudes da atuação do Serviço Social no campo educacional, no cenário brasileiro. 
Para Martinelli (1999, p.115):

A pesquisa qualitativa se insere no marco de referência da dialética, direcionando-se fundamentalmente, pelos objetivos buscados. O desenho da pesquisa qualitativa deve nos dar uma visibilidade muito clara do objeto, objetivo e metodologia, de onde partimos e onde queremos chegar.

A pesquisa documental foi realizada por meio dos dados fornecidos pelo Conselho Regional de Serviço Social da $9^{\text {a }}$ Região do estado de São Paulo. Foram levantados alguns estudos documentais por meio dos registros realizados pela categoria após vários encontros, seminários, congressos, e também outros como: artigos de jornal, fitas de vídeo, diversas produções científicas e acadêmicas produzidas em capítulos de livros, artigos em revistas profissionais e material on-line, em alguns sites das universidades que possuem cursos de graduação em Serviço Social (PUC/SP, UEL/PR, Unesp/Franca).

Todo esse material data o início da atuação do Serviço Social no campo educacional durante a década de 1940, no Brasil.

A primeira obra sobre o Serviço Social Escolar no Brasil foi da Assistente Social Maria Tereza Guilherme, área na qual também desenvolveu inúmeras atividades como pioneira nesse trabalho.

A profissional escreveu um livro intitulado Serviço Social Escolar, ${ }^{1}$ como resultado do trabalho de conclusão de curso apresentado à Escola de Serviço Social, para obtenção do título de assistente social, em 1945. E como introdução de seu trabalho de conclusão de curso, destaca-se: "Não tivemos que vacilar na escolha do tema 'Serviço Social Escolar', pois nenhum outro abraçaríamos com maior entusiasmo. Nenhum outro seria capaz de fazer-nos lutar com tanta energia como o fizemos aqui, pela educação da criança na harmonia social entre a família e a escola" (Fonte: Jornal Cras/SP/264 - Janeiro/ Fevereiro/1984).

1 O referido livro foi editado pelo Departamento de Educação daquela época e com prefácio do prof. Sud Mennucci, um destaque no magistério paulista. 
De acordo com Gil (2002, p.62-3), a pesquisa documental apresenta algumas vantagens por ser "fonte rica e estável de dados": não implica altos custos, não exige contato com os sujeitos da pesquisa e possibilita uma leitura aprofundada das fontes. Ela é semelhante à pesquisa bibliográfica, segundo o autor, e o que as diferencia é a natureza das fontes, sendo material que ainda não recebeu tratamento analítico, ou que ainda pode ser reelaborado de acordo com os objetivos da pesquisa.

Segundo Pádua (1997, p.62 ):

Pesquisa documental é aquela realizada a partir de documentos, contemporâneos ou retrospectivos, considerados cientificamente autênticos (não fraudados); tem sido largamente utilizada nas ciências sociais, na investigação histórica, a fim de descrever/comparar fatos sociais, estabelecendo suas características ou tendências [...]

Trata-se de uma pesquisa aleatória, intencional, pois a pesquisadora permaneceu durante um dia na Sede Administrativa do Conselho Regional de Serviço Social (Cress) do estado de São Paulo ${ }^{2}$ (A pesquisa documental foi realizada em 2006).

O material foi xerocopiado para a devida análise e reflexões para a concretização desse estudo.

2 O Conselho Regional de Serviço Social de São Paulo, Cress SP, $9^{\text {a }}$ Região integra o Conjunto CFESS/Cress, criado quando a profissão de Assistente Social foi regulamentada, pela Lei n ${ }^{\circ} 3.252 / 57$ e pelo Decreto $n^{\circ}$ 994/62 (hoje alterada para Lei 8.662/93), uma exigência constitucional para todas as atividades profissionais regulamentadas por lei. É uma entidade de direito público, e tem como competências: orientar, disciplinar, fiscalizar e defender o exercício da profissão de Serviço Social; zelar pelo livre exercício, dignidade e autonomia da profissão; organizar e manter o registro profissional dos assistentes sociais e das pessoas jurídicas que prestam serviços de consultoria e zelar pelo cumprimento e observância do Código de Ética Profissional (on-line). (Dados obtidos do site www.cress-sp.org.br, acesso em: 21 ago. 2008). 


\section{Dados históricos da inserção do Serviço Social no campo educacional}

Neste capítulo, são refletidas atuações históricas do Serviço Social na área da educação. Pode-se afirmar uma presença do profissional, assistente social, na política educacional brasileira? E/ou um Serviço Social Escolar? Em que diferenciam essas expressões ou atuações? Fatos históricos revelam que houve a tentativa da atuação da profissão nesta política social pública e privada, por meio de vários trabalhos isolados, em municípios do Brasil sem muitos avanços, contudo uma história tende a ser traçada no início desse terceiro milênio e escrita novamente, com apelos de organização da categoria na elaboração de leis que garantam efetivamente a atuação do Serviço Social na política educacional brasileira.

O Serviço Social do início do século XX, nasceu como uma profissão prático-interventiva, por meio de várias instituições prestadoras de serviço que atendiam às necessidades sociais de uma sociedade excluída do acesso à riqueza. Tem-se, a partir de então, condições históricas e materiais que justificam e ampliam essas ações sociais, determinando a legitimidade de uma profissão.

A presença de um Estado, que se redefinia politicamente e assumia a tarefa de prestador de serviços sociais à população de baixa renda, fortalecia a dependência de uma parcela da população que se tornava destinatária dependente dos serviços sociais assistencialistas.

No campo educacional, o Serviço Social surgiu em 1906, nos Estados Unidos, quando os Centros Sociais designaram visitadoras para estabelecer uma ligação com as escolas do bairro, a fim de averiguar por que as famílias não enviavam seus filhos à escola, as razões da evasão escolar ou a falta de aproveitamento das crianças e a adaptação destas à situação da escola. O mesmo trabalho ocorria na Europa junto ao campo assistencial que atendia a crianças abandonadas ou órfãs, mães solteiras, colocação em lares substitutos ou para adoção e serviços em instituições fechadas. Em vários países, ocorria o atendimento às crianças em suas famílias que não recebiam orientações necessárias para seu desenvolvimento e muitas eram 
vítimas de maus-tratos por parte dos pais ou responsáveis. Outros trabalhos na área escolar eram especializados no setor da saúde, resolvendo problemas de aprendizagem relacionados à saúde dos alunos (Vieira, B., 1977, p.67).

O trabalho desenvolvido pelo Serviço Social Escolar (assim intitulado) integrava a equipe multidisciplinar juntamente com psicólogos e professores. O objetivo era atender os alunos com problemas de aprendizagem. A tendência do Serviço Social era atender as dificuldades de caráter individual e familiar, configurados como problemas sociais, apresentados no espaço escolar.

$\mathrm{Na}$ América Latina, o trabalho profissional na área escolar embora atendesse individualmente, buscava a relação da escola com a comunidade por meio da família dos alunos.

O Serviço Social, até recentemente, não privilegiava a área da educação como campo de trabalho, sua história aponta para os "congressos internacionais e nacionais que estudavam a profissão em sua aplicação na sociedade para resolver os problemas apresentados dentro de determinado campo" (Vieira, B., 1977, p.66).

No Brasil, há relatos históricos de que os estados de Pernambuco e Rio Grande do Sul no ano de 1946, foram pioneiros no debate e no início do trabalho acerca do Serviço Social Escolar. No estado do Rio Grande do Sul, o Serviço Social foi implementado como serviço de assistência ao escolar na antiga Secretaria de Educação e Cultura. Suas atividades eram voltadas à identificação de problemas sociais emergentes que repercutissem no aproveitamento do aluno, bem como à promoção de ações que permitissem a adaptação dos escolares a seu meio e o equilíbrio social da comunidade escolar. Os assistentes sociais eram requisitados a intervir em situações escolares consideradas desvio, defeito ou anormalidade social (Amaro, 1997, p.51). E, em 1957, ocorre em Porto Alegre um seminário com o tema: "Educação para Adultos e Desenvolvimento de Comunidade", realizado pela Conferência Internacional de Serviço Social (C.I.S.S.) e a União Católica Internacional de Serviço Social (U.C.I.S.S), refletindo que a intervenção no espaço educacional seguia a lógica desenvolvimentista voltada à preparação social dos indivíduos a fim 
de torná-los, segundo suas aptidões, cidadãos produtivos e úteis ao capital (Vieira, B., 1977, p.178).

Até meados da década de 1970, o Serviço Social teve uma vinculação ideológica por subordinação ou opção ao projeto político do Estado legitimando a ordem vigente. Mas com o Movimento de Reconceituação fundamentado nos desdobramentos críticos da identidade profissional e no rompimento com um Serviço Social conservador e tradicional, é que a intervenção no contexto educacional ganhou novas perspectivas e destaque, especialmente na década de 1980.

Tem-se, hoje, muitas vezes, um Serviço Social restrito à educação infantil em creches e pré-escolas (centro de educação infantil), desenvolvido pelas Secretarias Municipais de Educação no Brasil. E no ensino fundamental é voltado também para população de baixa renda, no qual surgem várias expressões da questão social, que invadem o cenário escolar, tais como violência doméstica, dificuldades socioeconômicas das famílias, o uso indevido de drogas e o tráfico por familiares, crise de valores éticos e morais, que geram a indisciplina, o baixo rendimento escolar da criança e do adolescente, a evasão escolar e a falta de perspectiva de um futuro educacional.

Existem ainda algumas iniciativas universitárias que ocorrem no âmbito de Projetos de Extensão Universitária, por meio de supervisão de estágios na relação aluno e professor e na concessão de bolsas a alunos universitários de baixa renda. Contudo, é ainda um trabalho incipiente, pela ausência de profissionais nessa área.

A educação não é um campo de trabalho novo para o Serviço Social, como é conhecido, mas, nos últimos anos, percebe-se um crescente interesse dos assistentes sociais por esta área, em seu aspecto teórico-metodológico, como objeto de pesquisa e como campo interventivo, sobretudo na esfera pública, por meio de muitas contratações desse profissional para integrar a equipe profissional da educação nas escolas, em assessorias e consultorias no âmbito da política educacional estadual e nacional.

O Serviço Social, recentemente, tem sido reconhecido como profissão fundamental na perspectiva curricular da educação e ocupado 
espaços importantes no processo de execução da política educacional. Com isso, tende a deixar o serviço de ações complementares, paliativas e emergenciais. Seu trabalho consiste em identificar e propor alternativas de enfrentamento aos fatores sociais, políticos, econômicos e culturais que interferem no sistema educacional, de forma a cooperar com a efetivação da educação como um direito para a conquista da cidadania.

Foram pesquisados vários documentos como: os primeiros Projetos de Lei, da década de 1970 até os dias atuais, porém, vale ressaltar aqui, a existência de outros Projetos de Lei não relatados, visto que não se encontravam disponíveis no Cress, no período da pesquisa, relatos de experiência dos profissionais em vários lugares do País, produções científicas publicadas em anais de congressos, seminários nacionais e internacionais, revistas científicas, estudos dos órgãos representativos, como Cress e CFESS, livros e trabalhos de graduação e pós-graduação (que serão apresentados nesse capítulo), porém não se trata aqui de fazer um estudo detalhado sobre todos eles, mas uma referência sobre sua importância na história da profissão de Serviço Social, sobretudo no campo da Educação.

Diante desse estudo, é perceptível que a diversidade de Projetos de Lei (não será citada a autoria dos projetos visto ser irrelevante) nas esferas federal, estadual e municipal revelem, muitas vezes, o desconhecimento da profissão de Serviço Social, bem como as competências e atribuições do assistente social. Não se tem claro o conhecimento de como ou se a categoria dos assistentes sociais participou na elaboração desses projetos, assim como os investimentos necessários para uma composição de uma equipe mais ampla de profissionais que possam atuar de forma interdisciplinar nas unidades educacionais. É importante destacar que há uma ênfase na atuação dos assistentes sociais nas escolas em torno do tripé escola- famíliacomunidade, ainda que abordada de forma diferenciada e limitada da intervenção profissional.

O Projeto de Lei Federal nº 837/2003 em sua última versão (Anexo A), que se encontra em tramitação no Congresso Nacional, dispõe sobre a prestação de serviços de psicologia e de serviço social 
nas escolas públicas de educação básica, assim afirma no Art. $1^{\circ}$ : "O Poder Público deverá assegurar atendimento por psicólogos e assistentes sociais a alunos das escolas públicas de educação básica que dele necessitarem". Refere a um universo mais amplo de unidades de ensino, da criança ao jovem, de não se limita à perspectiva do Serviço Social Escolar no ensino fundamental, e em seu parágrafo $2^{\circ}$ expressa "Os sistemas de ensino, em articulação com os sistemas públicos de saúde e de assistência social, deverão prever a atuação de psicólogos e assistentes sociais nos estabelecimentos públicos de educação básica ou o atendimento preferencial nos serviços de saúde e assistência social a alunos das escolas públicas de educação básica [...]" (Quadro 1). Trata-se de um texto equivocado, com desconhecimento da profissão de Serviço Social, pois apresenta o trabalho do Serviço Social como uma ação complementar tanto na área da saúde como na política de assistência social. $\mathrm{O}$ atendimento dos profissionais na área da saúde possibilitará melhor desempenho do aluno no processo de aprendizagem, bem como a orientação aos profissionais da educação e familiares nesse resultado positivo.

Os Projetos de Leis Federais expõem a atuação de um Serviço Social Escolar, restrito a ações emergenciais, paliativas e assistencialistas, com uma intervenção reducionista da profissão, conforme o quadro 1. Todos os projetos foram vetados, salvo o projeto acima citado que se encontra em exame.

O Projeto de Lei Federal n ${ }^{\circ}$ 2.006/74 propõe a modificação de um artigo da LDB de 1971, instituindo a obrigatoriedade do Serviço Social Escolar nos $1^{\circ}$ e $2^{\circ}$ graus das escolas públicas. Art. $10^{\circ}$ "Será instituída obrigatoriamente a Orientação Educacional, incluindo aconselhamento vocacional e Serviço Social Escolar, em cooperação com os professores, a família e a comunidade”. Esse projeto foi vetado.

Compreende-se uma atuação sócio-ocupacional do profissional limitada, o que para Almeida (2004, p.25), é importante analisar

Os limites de uma especialização e os alcances do exercício profissional nos marcos das políticas sociais setoriais e das instituições 
sociais, ou seja, se afirma a possibilidade de um Serviço Social específico para cada área: o Serviço Social Escolar, o Serviço Social da Saúde e o Serviço Social Jurídico entre outros [...] outro aspecto a considerar é o de reduzir a possibilidade de inserção dos assistentes sociais na política educacional aos estabelecimentos educacionais do ensino fundamental [...].

O quadro abaixo apresenta os resultados das buscas realizadas nos Projetos de Lei Federal apresentados para aprovação no Congresso.

Quadro 1 - Projetos de Lei Federal

\begin{tabular}{|c|c|c|c|c|}
\hline $\begin{array}{l}\text { Projetos de } \\
\text { Lei }\end{array}$ & Ano & $\begin{array}{c}\text { Proposta para o } \\
\text { Serviço Social na } \\
\text { Educação }\end{array}$ & Justificativa & $\begin{array}{c}\text { Situação } \\
\text { Atual }\end{array}$ \\
\hline $\begin{array}{l}\text { Projeto de } \\
\text { Lei n }^{\circ} 2.006\end{array}$ & 1974 & $\begin{array}{l}\text { Art. } 10^{\circ} \text { Será instituí- } \\
\text { da obrigatoriamente a } \\
\text { Orientação Educacio- } \\
\text { nal, incluindo aconse- } \\
\text { lhamento vocacionale } \\
\text { Serviço Social Escolar, } \\
\text { em cooperação com os } \\
\text { professores, a família e } \\
\text { a comunidade. }\end{array}$ & $\begin{array}{l}\text { Os problemas pre- } \\
\text { sentes no universo } \\
\text { escolar em torno das } \\
\text { expressões da ques- } \\
\text { tão social justificam a } \\
\text { atuação do assistente } \\
\text { social. }\end{array}$ & Vetado \\
\hline $\begin{array}{c}\text { Projeto de } \\
\text { Lei n }^{\circ} 1.995\end{array}$ & 1976 & $\begin{array}{l}\text { Reapresentação do } \\
\text { projeto anterior }\end{array}$ & $\begin{array}{l}\text { Reapresentação da } \\
\text { justificativa anterior }\end{array}$ & Vetado \\
\hline $\begin{array}{c}\text { Projeto de } \\
\text { Lei n }^{\circ} 2.349\end{array}$ & 1996 & $\begin{array}{l}\text { Art. } 1^{\circ} \text { - Todas as ins- } \\
\text { tituições ou empresas } \\
\text { urbanas e rurais que } \\
\text { atuam na produção, } \\
\text { prestação de serviços, } \\
\text { assistência social, pla- } \\
\text { nejamento, previdên- } \\
\text { cia, habitação, edu- } \\
\text { cação, saúde e ação } \\
\text { comunitária, devem } \\
\text { contratar e manter } \\
\text { em seus quadros o } \\
\text { Assistente Social. }\end{array}$ & $\begin{array}{l}\text { A justificação do } \\
\text { Projeto se dá pela } \\
\text { importância da po- } \\
\text { lítica de assistência } \\
\text { social no Brasil, que } \\
\text { deve deixar de ser } \\
\text { compensatória, e } \\
\text { passar a ser política } \\
\text { pública de valoriza- } \\
\text { ção e incentivo ao } \\
\text { trabalhador e aten- } \\
\text { dimento adequado } \\
\text { aos usuários, em um } \\
\text { país de imensas de- } \\
\text { mandas sociais. }\end{array}$ & Vetado \\
\hline
\end{tabular}


Quadro 1-Continuação

\begin{tabular}{|c|c|c|c|c|}
\hline $\begin{array}{c}\text { Projetos de } \\
\text { Lei }\end{array}$ & Ano & $\begin{array}{l}\text { Proposta para o } \\
\text { Serviço Social na } \\
\text { Educação }\end{array}$ & Justificativa & $\begin{array}{c}\text { Situação } \\
\text { Atual }\end{array}$ \\
\hline $\begin{array}{c}\text { Projeto de } \\
\text { Lei n }^{\circ} 3.689\end{array}$ & 2000 & $\begin{array}{l}\text { O texto limita a atua- } \\
\text { ção do profissional } \\
\text { de Serviço Social aos } \\
\text { problemas de evasão } \\
\text { escolar e repetência, } \\
\text { é bastante conciso e } \\
\text { não faz referência às } \\
\text { competências dos as- } \\
\text { sistentes sociais nas } \\
\text { escolas públicas. }\end{array}$ & $\begin{array}{l}\text { A justificativa do } \\
\text { projeto fica circuns- } \\
\text { crita ao enfrenta- } \\
\text { mento dos processos } \\
\text { de evasão e repetên- } \\
\text { cia escolar. }\end{array}$ & Vetado \\
\hline $\begin{array}{l}\text { Projeto de } \\
\text { Lei n }^{\circ} 837\end{array}$ & 2003 & $\begin{array}{l}\text { Art. } 1^{\circ} \text { O Poder Pú- } \\
\text { blico deverá assegurar } \\
\text { atendimento por psi- } \\
\text { cólogos e assistentes } \\
\text { sociais a alunos das } \\
\text { escolas públicas de } \\
\text { educação básica que } \\
\text { dele necessitarem. }\end{array}$ & $\begin{array}{l}\text { A presença e atuação } \\
\text { da equipe profissio- } \\
\text { nal justifica-se pelos } \\
\text { problemas viven- } \\
\text { ciados por tantas fa- } \\
\text { mílias, objetivando } \\
\text { contribuir para um } \\
\text { melhor desempenho } \\
\text { dos alunos no proces- } \\
\text { so de aprendizagem. }\end{array}$ & $\begin{array}{c}\text { Em } \\
\text { tramitação }\end{array}$ \\
\hline
\end{tabular}

Fonte: Elaborado pela pesquisadora para fins didáticos

Para o Projeto de Lei Federal n ${ }^{\circ}$ 1.995/76, não houve alterações, mas trata-se de uma reapresentação do projeto anterior (n²006/74), para dar continuidade aos mesmos objetivos anteriores e imprimir uma "marca ideológica dos tempos da ditadura à intervenção que se desejava produzir com a inserção dos assistentes sociais nas escolas. O Art. $10^{\circ}$ apresenta: "Será instituída obrigatoriamente a Orientação Educacional, inclusive aconselhamento vocacional, e Serviço Social Escolar, em cooperação com os professores, a família e a comunidade". A justificativa é que a assistência social escolar enfrentará o "mal" que está na vida dos alunos e de suas famílias e não na vida escolar, como: inclinação à delinquência, má frequência às aulas, comportamento sexual irregular, carências emocionais, irregularidades no lar e outros.

O Projeto de Lei Federal nº 2.349/96 estabelece a importância dos profissionais assistentes sociais em todas as instituições prestadoras de serviço à população, em seu Art. $1^{\circ}$ - "Todas as instituições 
ou empresas urbanas e rurais que atuam na produção, prestação de serviços, assistência social, planejamento, previdência, habitação, educação, saúde e ação comunitária, devem contratar e manter em seus quadros o Assistente Social”. A justificação do Projeto dá-se pela importância da política de assistência social no Brasil, que deve deixar de ser compensatória, e passar a ser política pública de valorização e de incentivo ao trabalhador e atendimento adequado aos usuários, em um país de imensas demandas sociais.

O Projeto de Lei Federal n ${ }^{\circ}$ 3.689/00 limita a atuação do profissional de Serviço Social aos problemas de evasão e de repetência escolar; é bastante conciso e não faz referência às competências dos assistentes sociais nas escolas públicas. Responsabiliza as famílias pelos problemas de "desajustes comportamentais dos estudantes", dando ao assistente social o foco de trabalho, a fim de apoiá-las na superação das dificuldades.

Segundo Almeida (2004, p.38), a família hoje tem sido o alvo de todas as contradições e conflitos do sistema vigente, ou seja,

A partir da hegemonia do pensamento neoliberal no âmbito do Estado, os programas sociais dirigidos à família tendem a transferir para elas uma série de responsabilidades das quais o Estado tem se isentado, ou seja, se retira da esfera pública e do campo do reconhecimento dos direitos sociais uma série de cuidados e os desloca para a esfera privada, para o campo da dinâmica familiar. Assim, todo o processo de mudanças sofrido pela família ao longo das últimas duas décadas, tem sido acompanhado de ações públicas que combinam de forma desigual uma variedade de estratégias de amenização de algumas de suas necessidades com o aumento das suas responsabilidades do ponto de vista legal e das expectativas sociais quanto ao seu papel.

É possível observar nos diversos textos das leis federais apresentadas a ausência de uma análise mais aprofundada da realidade educacional por parte dos legisladores, a redução da atuação do profissional de Serviço Social nas escolas públicas e o não enfrentamento das causas dos problemas que assolam o processo educacional dos cidadãos. 
No quadro abaixo são apresentados os Projetos de Lei propostos por alguns estados brasileiros.

Quadro 2 - Projetos de Lei Estadual

\begin{tabular}{|c|c|c|c|c|}
\hline $\begin{array}{l}\text { Projetos } \\
\text { de Lei }\end{array}$ & $\begin{array}{l}\text { Ano/ } \\
\text { Estado }\end{array}$ & $\begin{array}{l}\text { Proposta para o Serviço } \\
\text { Social na Educação }\end{array}$ & Justificativa & $\begin{array}{l}\text { Situação } \\
\text { Atual }\end{array}$ \\
\hline $\begin{array}{c}\text { Projeto } \\
\text { de Lei } \\
n^{\circ} 2.514\end{array}$ & $\begin{array}{c}1998 \\
\text { Rio de } \\
\text { Janeiro }\end{array}$ & $\begin{array}{l}\text { Art. } 1^{\circ} \text { Autoriza o Poder } \\
\text { Executivo a instituir o } \\
\text { Serviço Social nas Escolas } \\
\text { Estaduais de } 1^{\circ} \text { e } 2^{\circ} \text { graus } \\
\text { do Estado do Rio de Janeiro }\end{array}$ & $\begin{array}{l}\text { Atuação inves- } \\
\text { tigativa da pro- } \\
\text { fissão no que } \\
\text { diz respeito aos } \\
\text { problemas que } \\
\text { atingem o jovem } \\
\text { no seu processo } \\
\text { educacional. }\end{array}$ & Vetado \\
\hline $\begin{array}{c}\text { Projeto } \\
\text { de Lei n } \\
1.297\end{array}$ & $\begin{array}{l}2003 \\
\text { Minas } \\
\text { Gerais }\end{array}$ & $\begin{array}{l}\text { Art. } 1^{\circ} \text { Fica instituído o } \\
\text { Serviço Social na rede pú- } \\
\text { blica de ensino do Estado, } \\
\text { voltado ao atendimento às } \\
\text { comunidades escolares e a } \\
\text { ser desenvolvido de forma } \\
\text { integrada às demais políti- } \\
\text { cas setoriais. }\end{array}$ & $\begin{array}{l}\text { Deverá atender } \\
\text { ao aluno para sua } \\
\text { permanência na } \\
\text { escola e integrar } \\
\text { família, escola e } \\
\text { comunidade. }\end{array}$ & $\begin{array}{l}\text { Aprovado } \\
\text { em } 2005\end{array}$ \\
\hline $\begin{array}{l}\text { Projeto } \\
\text { de Lei n } \\
161\end{array}$ & $\begin{array}{l}2005 \\
\text { Ceará }\end{array}$ & $\begin{array}{l}\text { Art. } 1^{\circ} \text { Fica criado o Servi- } \\
\text { ço Social Escolar nas esco- } \\
\text { las públicas do Estado, com } \\
\text { objetivo de prestar assistên- } \\
\text { cia social aos alunos e seus } \\
\text { familiares. }\end{array}$ & $\begin{array}{l}\text { Necessidade } \\
\text { de conhecer os } \\
\text { problemas que } \\
\text { atingem o de- } \\
\text { sempenho do } \\
\text { aluno na escola, } \\
\text { diagnosticar as } \\
\text { causas e atuar de } \\
\text { forma preventiva } \\
\text { e curativa. }\end{array}$ & $\begin{array}{c}\text { Em } \\
\text { tramitação }\end{array}$ \\
\hline
\end{tabular}

Fonte: Elaborado pela pesquisadora para fins didáticos

No estado de São Paulo existem vários Projetos de Lei com pareceres favoráveis que estão passando por diferentes redações (Quadro 3), contudo ainda nenhuma Lei foi aprovada, diferente de outros estados, como o estado de Minas Gerais com o Projeto de Lei $\mathrm{n}^{\circ}$ 1.297/03, aprovado em 2005, institui, ainda que de forma operacional e limitada, a presença do Serviço Social na rede pública de ensino do estado, voltado ao atendimento às comunidades escolares e a ser desenvolvido de forma integrada às demais políticas setoriais. Deverá atender diretamente o aluno na escola, trabalhar sua permanência na escola e integrar família, escola e comunidade. 
Outro exemplo é o estado do Ceará que cria o Serviço Social Escolar nas escolas públicas do estado com o Projeto de Lei n 161/05, objetivando prestar assistência social aos alunos e a seus familiares.

As atribuições do Serviço Social compreendem desde a pesquisa socioeconômica e familiar, elaboração de programas em atendimentos aos problemas sociais até as que estão contempladas nos artigos $4^{\circ}$ e $5^{\circ}$ da Lei Federal 8.662/93, que dispõe sobre a profissão de assistente social.

O Projeto é justificado pela necessidade de conhecer os problemas que atingem o desempenho do aluno na escola, diagnosticar as causas e atuar de forma preventiva e curativa.

Outro estado a apresentar uma proposta da atuação do Serviço Social Escolar nas escolas de $1^{\circ}$ e $2^{\circ}$ graus, é o Rio de Janeiro, com o Projeto de Lei ${ }^{\circ}$ 2.514/98, que propõe uma atuação investigativa da profissão no que diz respeito aos problemas que atingem o jovem em seu processo educacional e suas famílias, até as atribuições previstas na Lei Federal 8.662/93 que dispõe sobre a profissão de Assistente Social. Entretanto tal projeto foi vetado pelo governador alegando desconformidade com a vigente ordem jurídica e a inobservância da Constituição Federal.

No estado de São Paulo, são vários os municípios que fizeram e fazem a história do Serviço Social na Educação, mesmo na ausência de legislações que legitimem essa intervenção: Leme, Barretos (cenário da pesquisa de campo), Osasco (1996), Cosmópolis, Dracena, Itatiba, Limeira (1997), Franca (1978), Matão, Serrana, Tupã, Votuporanga, Marília, Mauá, São José dos Campos, Presidente Prudente (1991) e outras experiências que estão surgindo no estado, mas não foram registradas oficialmente.

Os Projetos de Leis do estado de São Paulo apresentam a atuação de um Serviço Social Escolar, na maioria deles dentro das unidades de ensino e diretamente com o aluno mediante o comportamento de ausência nas aulas, a rebeldia, a agressividade, a improdutividade, o desajustamento e a marginalização. Apontam uma profissão curativa, detentora de um conhecimento para sanar os problemas de ordem emocional e social, conforme segue quadro a seguir. 
Quadro 3 - Projetos de Lei do estado de São Paulo

\begin{tabular}{|c|c|c|c|c|}
\hline $\begin{array}{c}\text { Projetos de } \\
\text { Lei }\end{array}$ & Ano & $\begin{array}{l}\text { Proposta para o } \\
\text { Serviço Social na } \\
\text { Educação }\end{array}$ & Justificativa & $\begin{array}{c}\text { Situação } \\
\text { Atual }\end{array}$ \\
\hline $\begin{array}{l}\text { Projeto de } \\
\text { Lei n } 59\end{array}$ & 1978 & $\begin{array}{l}\text { Art. } 3^{\circ} \text { - Serão atri- } \\
\text { buições do Setor de } \\
\text { Serviço Social Escolar } \\
\text { o tratamento psico- } \\
\text { social aos membros } \\
\text { do corpo discente, } \\
\text { a promoção da in- } \\
\text { teração de grupos, } \\
\text { a orientação social, } \\
\text { a integração escola- } \\
\text { comunidade, a asses- } \\
\text { soria às associações } \\
\text { ligadas às unidades de } \\
\text { ensino, o desenvolvi- } \\
\text { mento de campanhas, } \\
\text { seminários e ciclos de } \\
\text { estudos, o incremento } \\
\text { das atividades de lazer } \\
\text { e a formação de grupos } \\
\text { voltados para a prática } \\
\text { cultural e desportiva, } \\
\text { dentre outras. }\end{array}$ & $\begin{array}{l}\text { A criação do setor de } \\
\text { Serviço Social Escolar } \\
\text { enaltece os problemas } \\
\text { de ordem psicológi- } \\
\text { ca com o argumento } \\
\text { mais adequado para } \\
\text { criação do setor de } \\
\text { psicologia da Edu- } \\
\text { cação. }\end{array}$ & Vetado \\
\hline $\begin{array}{l}\text { Projeto de } \\
\text { Lei n }{ }^{\circ} 374\end{array}$ & 1981 & $\begin{array}{l}\text { Reitera a abordagem } \\
\text { do projeto anterior, } \\
\text { enfatizando a atuação } \\
\text { dos assistentes sociais } \\
\text { nos programas de la- } \\
\text { zer, esporte e cultura. }\end{array}$ & $\begin{array}{l}\text { Ênfase na ação vol- } \\
\text { tada para a relação } \\
\text { escola-família-comu- } \\
\text { nidade }\left(\operatorname{art.} 3^{\circ}\right) \text {. }\end{array}$ & Vetado \\
\hline $\begin{array}{l}\text { Projeto de } \\
\text { Lei n }^{\circ} 336\end{array}$ & 1983 & $\begin{array}{l}\text { Art. } 4^{\circ} \text { é objetivo ge- } \\
\text { ral do Serviço Social } \\
\text { na Escola concorrer } \\
\text { para a plena realização } \\
\text { desta instituição edu- } \\
\text { cadora, socializadora, } \\
\text { integradora, transfor- } \\
\text { madora e conscien- } \\
\text { tizadora, com vistas } \\
\text { ao Desenvolvimento } \\
\text { Social. }\end{array}$ & $\begin{array}{l}\text { A justificativa apre- } \\
\text { sentada quanto à pre- } \\
\text { sença dos assistentes } \\
\text { sociais nas escolas de } \\
1^{\circ} \text { e } 2^{\circ} \text { graus ainda } \\
\text { conserva a noção de } \\
\text { que os problemas são } \\
\text { decorrentes da etapa } \\
\text { da juventude em que } \\
\text { se encontram esses } \\
\text { alunos e de respon- } \\
\text { sabilidade da família, } \\
\text { sendo esses o alvo da } \\
\text { ação profissional. }\end{array}$ & Vetado \\
\hline
\end{tabular}


Quadro 3-Continuação

\begin{tabular}{|c|c|c|c|c|}
\hline $\begin{array}{l}\text { Projetos de } \\
\text { Lei }\end{array}$ & Ano & $\begin{array}{l}\text { Proposta para o } \\
\text { Serviço Social na } \\
\text { Educação }\end{array}$ & Justificativa & $\begin{array}{l}\text { Situação } \\
\text { Atual }\end{array}$ \\
\hline $\begin{array}{l}\text { Projeto de } \\
\text { Lei n }{ }^{\circ} 268\end{array}$ & 1983 & $\begin{array}{l}\text { Reapresentação do } \\
\text { Projeto de Lei }{ }^{\circ} \\
374 / 81\end{array}$ & $\begin{array}{l}\text { Sua relevância justi- } \\
\text { fica-se. }\end{array}$ & Vetado \\
\hline $\begin{array}{l}\text { Projeto de } \\
\text { Lei n } 09\end{array}$ & 1984 & $\begin{array}{l}\text { Art. } 2^{\circ} \text { O Serviço } \\
\text { Social tem como seu } \\
\text { campo de trabalho } \\
\text { as relações entre os } \\
\text { agentes do processo } \\
\text { educativo: estudantes, } \\
\text { pais, trabalhadores da } \\
\text { escola e representantes } \\
\text { da comunidade. }\end{array}$ & $\begin{array}{l}\text { Justifica-se pela im- } \\
\text { portância da partici- } \\
\text { pação da população } \\
\text { nas políticas sociais } \\
\text { na perspectiva de } \\
\text { seus direitos. }\end{array}$ & Vetado \\
\hline $\begin{array}{l}\text { Projeto de } \\
\text { Lei n }^{\circ} 517\end{array}$ & 1987 & $\begin{array}{l}\text { Reedição do Projeto } \\
\text { de Lei n } 336 / 83\end{array}$ & $\begin{array}{l}\text { Reedição do Projeto } \\
\text { de Lei n }{ }^{\circ} 336 / 83\end{array}$ & Vetado \\
\hline $\begin{array}{l}\text { Projeto de } \\
\text { Lei n }{ }^{\circ} 442\end{array}$ & 1995 & $\begin{array}{l}\text { Segundo o art. } 2^{\circ} \text { as } \\
\text { competências do Ser- } \\
\text { viço Social Escolar } \\
\text { estão previstas na Lei } \\
8662 / 93 \text { que regula- } \\
\text { menta a profissão. }\end{array}$ & $\begin{array}{l}\text { Mantém a mesma } \\
\text { base de justificação } \\
\text { do Projeto de Lei n } \\
\text { 336/83. }\end{array}$ & Vetado \\
\hline $\begin{array}{l}\text { Projeto de } \\
\text { Lei n }{ }^{\circ} 925\end{array}$ & 2003 & $\begin{array}{l}\text { Art. } 1^{\circ} \text { - Institui o Ser- } \\
\text { viço social nas Escolas } \\
\text { Estaduais de } 1^{\circ} \text { e } 2^{\circ} \\
\text { graus. } \\
\text { Reitera as propostas } \\
\text { dos projetos anteriores. }\end{array}$ & $\begin{array}{l}\text { Justifica-se pela im- } \\
\text { portância da forma- } \\
\text { ção educacional da } \\
\text { criança e do adoles- } \\
\text { cente que não se rea- } \\
\text { liza somente na sala } \\
\text { de aula [...]. }\end{array}$ & Vetado \\
\hline $\begin{array}{l}\text { Projeto de } \\
\text { Lei n }{ }^{\circ} 1119\end{array}$ & 2003 & $\begin{array}{l}\text { Art. } 1^{\circ} \text { Fica instituído } \\
\text { o Programa Escolar } \\
\text { de Acompanhamento } \\
\text { Domiciliar. (PEAD) } \\
{[\ldots] \text { na rede estadual, }} \\
\text { no combate à depen- } \\
\text { dência química e sanar } \\
\text { os problemas domésti- } \\
\text { cos que interferem no } \\
\text { aproveitamento esco- } \\
\text { lar [...]. }\end{array}$ & $\begin{array}{l}\text { A equipe profissio- } \\
\text { nal deverá aprimorar } \\
\text { o processo de apren- } \\
\text { dizagem, por meio } \\
\text { da melhoria das rela- } \\
\text { ções familiares (não } \\
\text { determina a equipe } \\
\text { profissional, justifica } \\
\text { que será utilizado o } \\
\text { concurso de pedago- } \\
\text { gos, psicopedagogos } \\
\text { e assistentes sociais. }\end{array}$ & Aprovado \\
\hline
\end{tabular}

Fonte: Elaborado pela pesquisadora para fins didáticos 
Assim destaca o Projeto de Lei n ${ }^{\circ}$ 59/78 em seu artigo $3^{\circ}$ :

Art. $3^{\circ}$ - Serão atribuições do Setor de Serviço Social Escolar o tratamento psicossocial aos membros do corpo discente, a promoção da interação de grupos, a orientação social, a integração escola-comunidade, a assessoria às associações ligadas às unidades de ensino, o desenvolvimento de campanhas, seminários e ciclos de estudos, o incremento das atividades de lazer e a formação de grupos voltados para a prática cultural e desportiva, dentre outras.

O texto apresenta os métodos tradicionais de intervenção do Serviço Social: caso, grupo e comunidade, e amplia o trabalho dentro das escolas para as áreas da cultura, esporte e lazer. Também não é questionada a organização do sistema educacional e as determinações sociais colocam-se como objeto de atuação dos assistentes sociais (Almeida, 2004, p.27).

O Projeto de Lei $n^{\circ}$ 374/81 reitera a abordagem do projeto anterior, enfatizando a atuação dos assistentes sociais nos programas de lazer, esporte e cultura, com ênfase em uma ação voltada para a relação escola-família-comunidade (art. $3^{\circ}$ ). É importante ressaltar que há uma ênfase dos projetos na atuação dos assistentes sociais em torno desse tripé (escola-família-comunidade), mesmo que apresentem perspectivas de intervenção diferenciadas.

O Projeto de Lei n ${ }^{\circ} 336 / 83$ apresenta alguns elementos novos em relação ao anterior, mas conserva o trabalho assentado na relação escola-família-sociedade. A implementação de um Serviço Social na Escola pode expressar uma mudança em curso na própria profissão, pois tem-se um redirecionamento da abordagem da profissão, saindo da perspectiva psicossocial para uma análise mais política da atuação dos profissionais (Almeida, 2004, p.28). O artigo $4^{\circ}$ em seu Parágrafo $1^{\circ}$ diz: "[...] participar da formulação e implementação das políticas sociais e seus respectivos planos que forem formados ao nível da educação sistemática e assistemática".

A justificativa apresentada quanto à presença dos assistentes sociais nas escolas de $1^{\circ}$ e $2^{\circ}$ graus ainda conserva a noção de que os 
problemas são decorrentes da etapa da juventude em que se encontram esses alunos e de responsabilidade da família, com isso é alvo da ação profissional.

O Projeto de Lei n 268/83 é a reapresentação do Projeto de Lei $n^{\circ} 374$ de 1981 com a esperança de ser aprovado, considerando sua relevância como justificativa.

Para o Projeto $n^{\circ}$ 09/84 apresenta um significativo avanço em relação aos anteriores, pois é elaborado por uma assistente social que ocupou um cargo político. O Projeto enfatiza a dimensão política do trabalho dos assistentes sociais e assinala uma relação entre os objetivos do Serviço Social e as lutas sociais realizadas pela educação pública. Apresenta a atuação do profissional junto ao segmento estudantil, às famílias e aos trabalhadores da escola. Em seu Art. $2^{\circ}$ apresenta: - "O Serviço Social tem como seu campo de trabalho as relações entre os agentes do processo educativo: estudantes, pais, trabalhadores da escola e representantes da comunidade". Segundo o artigo $3^{\circ}$, inova com o trabalho profissional na perspectiva de vida e de trabalho da população: "O Serviço Social na Escola tem por objetivo geral, contribuir para que o processo educacional corresponda aos direitos, necessidades e melhores condições de vida e trabalho da população [...] cumprir plenamente suas finalidades de formação e transformação social”. O projeto apresenta ainda a importância da participação da população nas políticas sociais na perspectiva de seus direitos fundamentais.

Outro Projeto de Lei apresentado é o n 517/87, uma reedição do Projeto de Lei n ${ }^{\circ} 336 / 83$, já exposto aqui.

O Projeto de Lei $n^{\circ} 442 / 95$, elaborado por um parlamentar, contou com a iniciativa da organização de várias instituições públicas e particulares (Escolas de Serviço Social) e o Cress-SP, na elaboração de um documento para instituir o Serviço Social nas escolas. É justificado pelas bases do Projeto 336/83, mas com alterações nas competências do Serviço Social nas escolas de $1^{\circ}$ e $2^{\circ}$ graus do estado de São Paulo, buscando um ajuste com a Lei 8662/93 que regulamenta a profissão de assistente social e retornando às concepções do trabalho profissional nos espaços escolares. Esse é um projeto vetado pelo governador na época, justificando inconstitucionalidade. 
Em 2003, é apresentado o Projeto de Lei de n 925/03, que visa assegurar nas escolas estaduais de $1^{\circ}$ e $2^{\circ}$ graus a presença de assistentes sociais. Segundo parágrafo único do artigo $1^{\circ}$ :

Parágrafo Único - Compete ao Serviço Social Escolar: I - Efetuar levantamento de natureza socioeconômico e familiar para caracterização da população escolar; II - Elaborar e executar programas de orientação sociofamiliar visando a prevenção da evasão escolar e melhorar o desempenho do aluno; III - Integrar o Serviço Social Escolar a um sistema de proteção social mais amplo, operando de forma articulada outros benefícios e serviços assistenciais, voltado aos pais e alunos no âmbito da Educação em especial, e no conjunto das demais políticas sociais, instituições privadas e organizações comunitárias locais, para atendimento de suas necessidades; IV Coordenar os programas assistenciais já existentes na escola, como a merenda escolar e outros; $\mathrm{V}$ - Realizar visitas domiciliares com o objetivo de ampliar o conhecimento acerca da realidade sociofamiliar do aluno, possibilitando assisti-lo adequadamente; VI - Participar em equipe multidisciplinar, da elaboração de programas que visem a prevenir a violência, o uso de drogas e o alcoolismo, bem como o esclarecimento sobre doenças infectocontagiosas e demais questões de saúde pública; VII - Elaborar e desenvolver programas específicos nas escolas onde existam classes especiais [...].

Trata-se de um Projeto que ratifica as propostas dos anteriores, considerando a importância do Serviço Social no trabalho da educação pública, ocupando espaços dentro da escola e atendendo aos problemas vivenciados pelos alunos, familiares, professores e funcionários da educação.

Ainda no ano de 2003, o Projeto de Lei Estadual n 1119 institui o Programa de Acompanhamento Domiciliar, "destinado a promover a integração dos alunos da rede estadual e seus familiares, de forma a otimizar o binômio ensino-aprendizagem" (art. $1^{\circ}$ ). Justifica-se pela importância de uma equipe profissional de assistentes sociais, pedagogos, psicopedagogos, docentes e corpo administrativo da 
escola no trabalho da melhoria das relações familiares, visando ao aprimoramento do processo de aprendizagem. Esse Projeto teve sua data de aprovação com a publicação no Diário Oficial no dia 31/10/2003, p.34.

Por fim foram pesquisados alguns Projetos de Lei Municipal (Quadro 4), como: Projeto de Lei n 13.780 de 2004, do município de São Paulo, para a criação do Programa de Atenção à Saúde do Escolar, o Serviço Social como suporte terapêutico interdisciplinar; o Projeto de Lei n 1.455 de 1996, do município de Ribeirão Preto/ SP, propondo um Serviço Social Escolar e sua redação não é muito diferente dos Projetos aqui elencados, contudo define o trabalho a ser realizado pelo Serviço Social dentro das escolas, desde conhecer o universo de todos os alunos, até desenvolver trabalhos específicos com classes especiais; o Projeto de Lei n 7.630 , de 1997, também do município de Ribeirão Preto/SP, contendo o mesmo teor do anterior. O texto legal foi aprovado havendo a regulamentação do Serviço Social na educação escolarizada; o Projeto de Lei sn/2003, do município de Vitória/ES, que destaca a atuação de um trabalho interdisciplinar e articulado com as outras políticas setoriais apresenta em seu artigo $2^{\circ}$ :

Art. $2^{\circ}$ - Parágrafo Único - As ações do Serviço social na educação serão executadas de forma interdisciplinar e integrada às demais políticas setoriais, visando compreender e mediar os aspectos econômicos, sociopolíticos e culturais da realidade social que interferem nas relações da comunidade escolar.

Como último projeto levantado, o Projeto de Lei n ${ }^{\circ}$ 7.438/03, do município de Campos de Goitacazes/RJ, é diferente dos demais projetos, pois institui o Serviço Social nas escolas e vincula o à Secretaria da Saúde, e não às secretarias da educação como todos os projetos apresentados. É uma lei aprovada e que tem suas escolas da rede municipal, creches, centros de qualidade de vida, postos de saúde e mini-hospitais de assistentes sociais lotados à Secretaria da Saúde. 
No quadro abaixo são apresentados os Projetos de Lei existentes em algumas cidades brasileiras.

Quadro 4-Projetos de Lei Municipal

\begin{tabular}{|c|c|c|c|c|}
\hline $\begin{array}{l}\text { Projetos } \\
\text { de Lei }\end{array}$ & $\begin{array}{l}\text { Ano/ } \\
\text { Estado }\end{array}$ & $\begin{array}{l}\text { Proposta para o } \\
\text { Serviço Social na } \\
\text { Educação }\end{array}$ & Justificativa & $\begin{array}{l}\text { Situação } \\
\text { Atual }\end{array}$ \\
\hline $\begin{array}{l}\text { Projeto de } \\
\text { Lei n }^{\circ} 09\end{array}$ & $\begin{array}{c}1984 \\
\text { São Paulo } \\
\text { (capital) }\end{array}$ & $\begin{array}{l}\text { Art. } 2^{\circ} \text { O Serviço So- } \\
\text { cial tem como seu } \\
\text { campo de trabalho as } \\
\text { relações entre os agen- } \\
\text { tes do processo educa- } \\
\text { tivo: estudantes, pais, } \\
\text { trabalhadores da es- } \\
\text { cola e representantes } \\
\text { da comunidade. }\end{array}$ & $\begin{array}{l}\text { Justifica-se pela } \\
\text { importância da } \\
\text { participação da } \\
\text { população nas } \\
\text { políticas sociais } \\
\text { na perspectiva } \\
\text { de seus direitos. }\end{array}$ & Vetado \\
\hline $\begin{array}{c}\text { Projeto de } \\
\text { Lei } \\
\mathrm{n}^{\circ} 1.455\end{array}$ & $\begin{array}{c}1996 \\
\text { Ribeirão } \\
\text { Preto/SP. }\end{array}$ & $\begin{array}{l}\text { Estabelece as compe- } \\
\text { tências do Serviço So- } \\
\text { cial, mesclando com } \\
\text { as atribuições previs- } \\
\text { tas na lei } 8662 / 93 \text { que } \\
\text { regulamenta a profis- } \\
\text { são de Serviço Social. } \\
\text { Institui Serviço Social } \\
\text { na educação pública. }\end{array}$ & $\begin{array}{l}\text { Luta pela am- } \\
\text { pliação e con- } \\
\text { quista dos di- } \\
\text { reitos sociais e } \\
\text { fortalecimento } \\
\text { de uma educa- } \\
\text { ção cidadã. }\end{array}$ & $\begin{array}{l}\text { Analisado } \\
\text { para a } \\
\text { aprovação }\end{array}$ \\
\hline $\begin{array}{l}\text { Projeto de } \\
\text { Lei } \\
n^{\circ} 7.630\end{array}$ & $\begin{array}{c}1997 \\
\text { Ribeirão } \\
\text { Preto/SP. }\end{array}$ & $\begin{array}{l}\text { A Lei contém o teor } \\
\text { do projeto anterior e } \\
\text { regulamenta o Servi- } \\
\text { ço Social na educação } \\
\text { escolarizada. }\end{array}$ & $\begin{array}{l}\text { Justifica-se pelo } \\
\text { projeto anterior. }\end{array}$ & ado \\
\hline $\begin{array}{l}\text { Projeto de } \\
\text { Lei s/n }\end{array}$ & $\begin{array}{c}2003 \\
\text { Vitória/ES. }\end{array}$ & $\begin{array}{l}\text { Apresenta a atuação } \\
\text { de um trabalho in- } \\
\text { terdisciplinar e arti- } \\
\text { culado com as outras } \\
\text { políticas setoriais. } \\
\text { Não detalha as com- } \\
\text { petências do assisten- } \\
\text { te social relacionadas } \\
\text { aos problemas nas } \\
\text { escolas. }\end{array}$ & $\begin{array}{l}\text { Importância de } \\
\text { um trabalho in- } \\
\text { terdisciplinar e } \\
\text { articulação com } \\
\text { as demais polí- } \\
\text { ticas sociais. }\end{array}$ & Apr \\
\hline $\begin{array}{l}\text { Projeto } \\
\text { de Lei } \\
\mathrm{n}^{\circ} 7.438\end{array}$ & $\begin{array}{c}2003 \\
\text { Campos dos } \\
\text { Goitacazes/ } \\
\text { RJ. }\end{array}$ & $\begin{array}{l}\text { Institui o Serviço } \\
\text { Social nas escolas e } \\
\text { vincula-o à Secretaria } \\
\text { da Saúde, e não à Se- } \\
\text { cretaria da Educação. }\end{array}$ & $\begin{array}{l}\text { A participação } \\
\text { dos assistentes } \\
\text { sociais ocorrerá } \\
\text { nos vários pro- } \\
\text { gramas desen- } \\
\text { volvidos pelas } \\
\text { prefeituras. }\end{array}$ & Aprovado \\
\hline
\end{tabular}


Quadro 4-Continuação

\begin{tabular}{|c|c|l|l|l|}
\hline $\begin{array}{c}\text { Projetos } \\
\text { de Lei }\end{array}$ & $\begin{array}{c}\text { Ano/ } \\
\text { Estado }\end{array}$ & $\begin{array}{c}\text { Proposta para o } \\
\text { Serviço Social na } \\
\text { Educação }\end{array}$ & Justificativa & $\begin{array}{c}\text { Situação } \\
\text { Atual }\end{array}$ \\
\hline $\begin{array}{c}\text { Projeto de } \\
\text { Lei } \\
\text { n }^{\circ} 13.780\end{array}$ & $\begin{array}{c}2004 \\
\text { São Paulo } \\
\text { (capital) }\end{array}$ & $\begin{array}{c}\text { Criação do Programa } \\
\text { de Atenção à Saúde } \\
\text { do Escolar. } \\
\text { Consiste em uma } \\
\text { parceria da Secretaria } \\
\text { da Educação com a a } \\
\text { Secretaria da Saúde, } \\
\text { atendendo aos alunos } \\
\text { comapoio às famílias. }\end{array}$ & $\begin{array}{c}\text { Serviço Social } \\
\text { atua como su- } \\
\text { porte terapêu- } \\
\text { tico interdisci- } \\
\text { plinar. }\end{array}$ & $\begin{array}{c}\text { Aprovado } \\
\text { em 2005 }\end{array}$ \\
\hline
\end{tabular}

Fonte: Elaborado pela pesquisadora para fins didáticos

É importante considerar que vários desses Projetos de Lei, aqui apresentados, estão em tramitação. Contudo, faz-se necessário um longo estudo e acompanhamento dos projetos de Lei que estão surgindo. É importante considerar que haja um amplo conhecimento da profissão de Serviço Social, bem como suas competências e atribuições a partir do projeto ético-político profissional, na elaboração dos novos projetos e que sejam devidamente acompanhados pelos profissionais envolvidos. Aos parlamentares e políticos em geral cabe a vontade política, prioridade mediante as demais políticas sociais e interesse em oferecer uma educação de oportunidades, participação e qualidade à população infanto juvenil.

É importante considerar que a maioria dos projetos apresentados limita-se à visão de que os problemas com os quais o assistente social deve trabalhar nas unidades de ensino estão relacionados ao comportamento do aluno, decorrentes de dificuldades de ajuste, em seu aspecto familiar, social ou econômico. Com isso torna-se difícil ao assistente social refletir o próprio processo educacional com seus interesses escusos e contradições, bem como as particularidades do seu trabalho profissional.

Nessa pesquisa documental, observa-se que a inserção dos assistentes sociais nas instituições de ensino, especialmente as escolas de educação básica, tem representado o desejo dessa categoria profissional e o resultado de sua atuação política e profissional na defesa 
dos direitos sociais, e revelado uma necessidade socioinstitucional cada vez mais reconhecida no âmbito do poder legislativo de muitos estados e municípios. Essa presença tem contribuído para a ampliação do processo educacional de um modo geral, para o acesso e a permanência da criança e do jovem na escola e estabelecer relações sociais, familiares e comunitárias visando a uma educação cidadã.

Nesse sentido, mediante uma concepção ampla da atuação do Serviço Social na Educação, são fundamentais uma mobilização da categoria profissional em torno do tema, uma assessoria na elaboração dos projetos de lei e a própria elaboração de um projeto pela categoria, um acompanhamento dos trabalhos desenvolvidos juntos às secretarias de educação, prefeituras e profissionais da educação, além de se considerar um trabalho a partir das particularidades de cada região do País e dos diferentes níveis de educação, de se refletir as possíveis fontes de custeio do trabalho (questão polêmica apresentada pelas prefeituras) e de um conhecimento amplo das estruturas de organização da política educacional em seus diferentes níveis.

Por fim, nesse estudo destacam-se a importância da participação da família, não só em seu papel complementar no processo educativo, mas em seu papel político por meio da participação na construção de uma escola democrática e da ampliação dos direitos sociais e ainda refletir a amplitude da inserção do Serviço Social na Educação: na educação básica (Educação Infantil, Ensino Fundamental e Ensino Médio) e na política educacional como um todo.

\section{A construção de uma identidade profissional no cenário educacional}

O Serviço Social vive hoje a expansão profissional por meio de novos espaços sócio-ocupacionais e a (re) inserção no cenário da política educacional tem revelado um grande desafio à profissão, pois aos assistentes sociais apresenta-se a necessidade de engajar-se nas instituições escolares, de elaborar e de implementar projetos de integração dos aspectos sociais e educacionais vividos pelos destina- 
tários dessa política social, de inserir-se profundamente na dinâmica do conhecimento pedagógico e de suas legislações que marcaram a construção de políticas educacionais nesse país.

O assistente social hoje busca fundamentar sua formação profissional a partir das novas Diretrizes Curriculares, com uma flexibilidade das disciplinas, podendo contemplar especificidades regionais e demandas geradas pelas necessidades, por meio de interlocuções com outras áreas do saber (pluralismo), a indissociabilidade nas dimensões ensino, pesquisa e extensão e a adoção de uma teoria social crítica que possibilite a apreensão da totalidade social em suas dimensões de universalidade, particularidade e singularidade.

Nessa perspectiva, é que o Serviço Social busca construir um perfil profissional na política educacional, conquistando espaços, protagonizando ações que possibilitem intervenções profissionais criativas, propositivas, estratégicas, ousadas, destemidas e comprometidas com a transformação social.

É o que se propõe a refletir nesse item, à luz do passado, da prática profissional histórica do Serviço Social no campo da educação desde a sua origem no Brasil, ao presente e o futuro a ser pensado, construído e conquistado pela profissão de Serviço Social nesse campo de intervenção.

\section{A dimensão educativa e pedagógica do Serviço Social}

Pensar a dimensão pedagógica e educativa do Serviço Social é remeter-se a um trabalho desenvolvido pelos profissionais na perspectiva de desmistificar e desvelar a realidade produtora e reprodutora de desigualdades, visando à autonomia, à participação e à emancipação dos indivíduos sociais. Traçar um perfil profissional educativo, representa à profissão a construção de meios para a superação da condição de opressão e de dominação das classes oprimidas e dominadas.

Mediante essa realidade, o Serviço Social é uma profissão que vem se construindo há sete décadas de existência no Brasil e no mundo; com seu caráter sociopolítico, crítico e interventivo, tem ampliado 
a ação em todos os espaços em que ocorrem as diversas refrações da questão social, ou seja, no conjunto de desigualdades que se originam do antagonismo entre a socialização da produção e a apropriação privada dos frutos do trabalho. Está inserido nas diversas áreas de direitos, no universo da família, no mundo do trabalho, nas políticas sociais públicas e privadas, nas questões ambientais, nos grupos étnicos, em diversos segmentos da sociedade brasileira: da criança, do adolescente, do jovem, do idoso e outras formas de violação dos direitos sociais. Tais situações demandam um trabalho de planejamento, de gerenciamento, de administração, de assessoramento às políticas, a programas e serviços sociais, de análise da realidade social e institucional, a ações incisivas e transformadoras junto à população usuária. Trabalha essencialmente as relações sociais por meio de uma ação global de cunho socioeducativo e de prestação de serviços.

Seu fazer profissional exige um conhecimento amplo sobre a realidade em sua complexidade e em criar meios para transformá-la na direção de seu projeto político-profissional. É por meio da mediação que o assistente social realiza esse enfrentamento no complexo tecido das organizações sociais em que atua (Pontes, 2000, p.43).

Segundo Martinelli (1993, p.136):

Mediações são categorias instrumentais pelas quais se processa a operacionalização da ação profissional. Expressam-se pelo conjunto de instrumentos, recursos, técnicas e estratégias e pelas quais a ação profissional ganha operacionalidade e concretude. São instâncias de passagem da teoria para a prática, são vias de penetração nas tramas constitutivas do real.

Dessa forma, é por meio da mediação que o profissional tem condições de traçar um direcionamento a sua prática de forma crítica e não alienada, a partir do seu projeto ético-político, o que possibilita uma ação transformadora.

A profissão sempre acompanhou as transformações da sociedade brasileira e construiu um projeto profissional, denominado projeto ético-político, a partir das décadas de 1970 e 1980, e que expressa 
o compromisso da categoria com a construção de uma nova ordem societária com justiça, democracia e garantia de direitos universais. Tal projeto tem seus princípios pautados na Lei 8662/93, no Código de Ética Profissional de 1993 e nas Diretrizes Curriculares com o redimensionamento em seu referencial teórico e metodológico, adequando criticamente a profissão às exigências dos novos tempos.

O Código de Ética veio nos últimos anos se atualizando ao longo da trajetória profissional. Em 1993, após um rico debate com o conjunto da categoria em todo o País, foi aprovada a quinta versão do Código de Ética Profissional, instituída pela Resolução 273/93 do CFESS.

O Código representa a dimensão ética da profissão, com seu caráter normativo e jurídico, delineia referenciais para o exercício profissional, define direitos e deveres dos assistentes sociais, buscando a legitimação social da profissão e a garantia da qualidade do trabalho desenvolvido. Ele expressa a renovação e o amadurecimento teórico-político do Serviço Social e evidencia em seus princípios fundamentais o compromisso ético-político assumido pela categoria.

A identidade da profissão não é estática. É construída historicamente desde o século XIX e hoje envolve as contradições sociais que configuram uma situação de barbárie, decorrentes da atual relação capital e trabalho, em suas fases de decadência monopolista, financeira e globalizada, com graves consequências na força de trabalho.

Para Cardoso \& Maciel (2000, p.142):

É incontestável a função educativa desempenhada pelos assistentes sociais nos diferentes espaços ocupacionais. Tal função caracteriza-se pela incidência dos efeitos das ações profissionais na maneira de pensar e agir dos sujeitos envolvidos nas referidas ações, interferindo na formação de subjetividades e normas de condutas, elementos estes constitutivos de um determinado modo de vida ou cultura.

Dessa forma, é importante considerar que a função pedagógica e educativa do assistente social ocorre por meio dos vínculos estabelecidos pela profissão com as classes sociais e se materializa, especialmente, por meio dos efeitos do trabalho profissional na maneira 
de pensar e de agir dos sujeitos envolvidos nos processos da prática. Essa função é "mediatizada pelas relações entre Estado e a sociedade civil no enfrentamento da questão social, integrada a estratégias de racionalização da produção e reprodução das relações sociais e do exercício do controle social”. (Abreu, 2001, p.17).

O Serviço Social desenvolve estratégias objetivadas pelas políticas sociais públicas e privadas, especialmente a assistência social, atendendo, sim, às necessidades de subsistência física do trabalhador, mas também nos processos de luta e de resistência das classes subalternas em contraposição à ordem do capital.

É importante considerar que a função educativa da intervenção do assistente social junto às classes subalternas, atende, em algumas vezes, as determinações dos donos do capital, pois tais serviços são demandados por estes para garantir a fixação de "valores e normas de comportamento junto ao trabalhador e sua família para o enquadramento nos padrões de sociabilidade às exigências do processo de acumulação capitalista" (Cardoso \& Maciel, 2000, p.143).

Não obstante, o movimento da sociedade, mediante as conflituosas relações sociais e tensões, revela as contradições do sistema vigente e altera o pseudoequilíbrio revelado pelas forças dominantes e dá abertura às críticas, à negação e à superação da ordem estabelecida.

É nessa perspectiva que a solicitação dessas classes pelo trabalho do assistente social demonstra a necessidade das frentes de lutas que caracterizam o projeto interventivo profissional. Tais frentes de luta indicam as possíveis respostas para atender as necessidades materiais e imediatas da população em seu pleno desenvolvimento humano, e às necessidades de formação e organização política.

Esses processos demonstram uma dimensão real de luta pela defesa e pela conquista dos direitos sociais e a busca da hegemonia no processo da construção de um novo projeto societário em detrimento da sociedade capitalista.

Nesse sentido, para Maciel (2000, p.144):

A função educativa dos assistentes sociais integra o amplo processo de elaboração de uma ideologia própria desenvolvido por essas 
classes, como elemento constitutivo de uma nova cultura. Supõe compromisso político consciente com o projeto societário das classes subalternas e competência teórica, metodológica e política para a identificação e apropriação das reais possibilidades postas pelo movimento social para o redimensionamento da prática profissional no horizonte da luta pela emancipação das referidas classes.

Assim, essa função educativa, contida no projeto ético-político da profissão, contribui para novas relações pedagógicas entre o assistente social e o usuário de seus serviços. Tais relações favorecem uma maior participação dos sujeitos envolvidos por meio do conhecimento crítico sobre a realidade e dos recursos institucionais para a construção de ações estratégicas, atendendo aos interesses das classes subalternas eà mobilização, à organização, ao fortalecimento e à instrumentalização das lutas para a conquista de uma classe hegemônica.

$\mathrm{O}$ aspecto educativo da profissão perpassa por todo contato do profissional com o usuário de seu trabalho. E o que espera desse profissional é que esteja devidamente habilitado para analisar e intervir na realidade social desenvolvendo sua formação teórico-metodológica, ético-política e técnico-operativa de forma crítica; saiba definir estratégias de intervenção para a garantia dos direitos do cidadão; saiba desenvolver trabalhos de parceria para assumir trabalhos de gestão pública na área das políticas sociais em geral; compreender a questão social bem como suas expressões na realidade social e estabelecer relações efetivas entre profissional e classe trabalhadora para um trabalho com perfil educativo e pedagógico comprometido.

\section{O Serviço Social na política educacional brasileira}

A educação no Brasil tem se destacado nas últimas décadas no cenário internacional por meio de eventos mundiais ${ }^{3}$ que resultaram

3 Eventos Mundiais: 1990: "Declaração para Todos"; 1994: Declaração de Salamanca - sobre Educação Especial; 1997: Educação de Jovens e Adultos. 
em diretrizes educacionais a serem observadas por todas as $\mathrm{Na}$ ções, reforçando a importância que a educação ocupa na sociedade globalizada.

No Brasil, a Constituição Federal de 1988 e a Lei de Diretrizes e Bases da Educação de 1996 declaram a educação como um direito social a ser garantido pelo Estado a toda sociedade, mas ainda não se constituiu efetivamente como uma política pública universal.

A realidade brasileira apresenta dados alarmantes na educação:

Não existe escola para todos em todos os níveis; $41 \%$ dos jovens não terminam ensino médio; $2 / 3$ dos jovens entre 15 e 17 anos não estão na escola; são elevados os índices de evasão e repetência escolar e analfabetismo. O Sistema Nacional de Avaliação da Educação Básica mostra que, entre 1995 e 2001, o desempenho discente piorou. Em 2002, 74\% dos que se submeteram à avaliação do Ensino Médio (Enem) tiveram desempenho insuficiente. Vale lembrar que, para o Ensino Médio, de cada cem estudantes, sessenta não o concluem, e que 53\% dos alunos estão atrasados na escola. (Backx, 2008, p.122)

Embora a educação seja declarada legalmente como direito humano prioritário, inalienável e de obrigação do Estado, ela expressa também os reflexos do mundo do trabalho e sofre as influências do mercado, da nova política de emprego do mundo moderno e da relação público e privado. Com isso, sua qualidade e efetivação atendem aos interesses do mercado e impõe desafios na conquista da cidadania.

É necessário buscar uma educação que objetive a formação de sujeitos capazes de pensarem por si mesmos, ou seja, que "assumam sua condição de sujeitos na dinâmica da vida social, sem perder de vista um projeto coletivo de sua transformação" (idem, p.122). Diante disso, trata-se de educar para o exercício de cidadania, proposta essa que ultrapassa o ambiente escolar, embora tendo a escola papel importante no processo ensino e aprendizagem de seus alunos.

Para Almeida (2000, p.158), a mais grave característica dessa política social, a educação, 
é a não universalização do acesso da população à educação escolarizada, decorrente, sobretudo, de um confronto de interesses alimentado e realimentado por uma cultura política excludente e elitizada, que não consegue incorporar a participação das massas nos ciclos de alternância do poder e desenvolvimento econômico.

Outro aspecto relevante dessa política setorial é sua descontinuidade, sendo muitas vezes apresentada como solução de problemas sociais emergentes, sem planejamento, imediatista e condicionada a interesses políticos e econômicos. Essa característica de descontinuidade ocorre em nível federal, estadual e municipal, por meio de montagem e desmontagem de programas e estruturas educacionais, como acontece com o ensino médio, o ensino profissionalizante, as escolas de período integral, os sistemas por ciclos, com acessos diretos e sem reprovação (Almeida, 2000b, p.158).

Tem ainda gerado muitos conflitos políticos e administrativos a definição constitucional dos percentuais oriundos da arrecadação de impostos da União (não menos que 18\%), estado e municípios para a educação (nunca menos que $25 \%$ da receita) e consequente exigência desse cumprimento, o que, na prática, essa legislação é, muitas vezes, burlada.

A educação enquanto política tem sido prioritária, em escala mundial e nacional, decorrente de uma evidente alteração de forma hegemônica nos padrões de organização social da produção. Para isso, destaca-se que

A intervenção do Banco Mundial na condução das políticas de educação é apoiada por um diagnóstico que aponta excessivos e desnecessários gastos públicos com educação superior, insuficiência de investimentos no ensino fundamental, ineficácia do ensino médio e necessidade de dinamização de um ensino profissional mais direcionado para as novas exigências do mercado de trabalho. O diagnóstico se completa com a eleição da educação como estratégia central para superar o atraso social e diminuir as desigualdades econômicas. (Tomasi et al. 1996 apud Almeida, 2000a, p.156) 
Os interesses escusos dessa ação do Banco Mundial, por meio de financiamentos diretos e de reorganização dos recursos públicos, diz respeito à inserção do Brasil como país periférico, na nova ordem mundial de padrões de consumo e produtor de mão de obra basicamente qualificada, de baixo custo e de atendimento às novas exigências de produção globalizada.

Dessa forma, desde a aprovação da Lei de Diretrizes e Bases da Educação Nacional, Lei n 9.394, de dezembro de 1996, o Brasil colocou seu "projeto educacional à disposição das necessidades sociais, técnicas e político-ideológicas da atual fase de expansão do capitalismo" (Almeida, 2000a, p.21). Especialmente quando substituiu o primeiro projeto de 1994, da LDBEN, discutido e negociado com muitas entidades e os movimentos sociais do campo educacional, por outro projeto do Ministério da Educação (MEC), articulado às diretrizes do Banco Mundial. E desde então, o MEC tem imposto várias reformas educacionais sem o diálogo e a participação da sociedade civil organizada e de profissionais do campo educacional.

Confirma Almeida (2000a, p.161) quando expõe que

A política desenvolvida pelo MEC nos últimos anos foi orientada, sobretudo pela necessidade de elevar o nível de escolaridade mínima da mão de obra no País e de empreender reformas no sentido de garantir sua integral adequação às novas exigências da esfera da produção e da cultura sem grandes investimentos, visto que deveria ser também funcional ao processo de ajuste fiscal imposto pela nova ordem econômica mundial. [...] A LDB contém um arcabouço geral de organização e orientação da política educacional referenciado pelas principais balizas do Estado neoliberal: a reforma administrativa e gerencial do Estado; a flexibilização das legislações exigida pela flexibilização da produção no mundo do trabalho; a substituição da lógica do pleno emprego pela da empregabilidade; a valorização ideológica da supremacia do mercado e da individualidade [...].

As reformas no campo educacional têm respondido às exigências do paradigma da empregabilidade e do interesse público e privado, 
ou seja, a inserção no mundo do trabalho é segundo os interesses do mercado, atendendo sua lucratividade e a busca da supremacia dos setores privados para uma educação mercantilizada e gerenciada pelo Estado, sem ações executivas, mas incorporando institucionalmente, a filantropia e o assistencialismo à rede de serviços públicos para a população de baixa renda, não equacionando a exclusão educacional e social (idem, p.21).

Enfim, tem-se hoje um amplo conjunto de mudanças acontecendo no sistema educacional brasileiro, desde a educação inicial até a educação superior. E é nesse vasto e complexo campo de atuação que o Serviço Social tem redefinido sua intervenção. São muitos assistentes sociais trabalhando diretamente com as instituições de ensino (públicas e privadas): nos Centros Municipais de Educação Infantil e Ensino Fundamental, nos conselhos municipais de educação, na assessoria e elaboração dos planos municipais e estaduais de educação, nos projetos de educação não formal, nas universidades por meio do estágio curricular, projetos de extensão universitária e a inserção do jovem de baixa renda no ensino superior e nas equipes interdisciplinares por meio da formação continuada dos profissionais da educação, ou seja, no campo da educação enquanto política social e como dimensão da vida social. Como exemplo, tem-se o Projeto de Extensão "Educação Pública e Serviço Social" da Faculdade de Serviço Social da Universidade do Estado do Rio de Janeiro. A categoria profissional tem-se destacado nesses trabalhos e ampliado suas ações realizando uma interface com outras políticas sociais previstas em leis, como o Estatuto da Criança e do Adolescente, Lei $n^{\circ}$ 8.069/90 e a Lei Orgânica de Assistência Social, Lei nº 8742/93 e pela importância estratégica que tem a educação nesse novo milênio.

Para Almeida (2000a, p.19-20), a relação teórico-prática no campo educacional pelo Serviço Social ocorreu com o reconhecimento da atuação do assistente social por meio da dimensão educativa de seu trabalho:

Durante muitos anos a associação entre Serviço Social e Educação esteve, quase que de forma automática, relacionada ou ao campo 
da formação profissional ou à dimensão educativa do trabalho dos assistentes sociais. As razões não nos são desconhecidas: uma franca alteração no perfil do mercado de trabalho, no que se tange à efetiva atuação dos assistentes sociais no âmbito dos estabelecimentos e da política educacional ao longo dos anos 70 e parte dos 80 , a afirmação do debate e das práticas sobre educação popular que se estenderam para além dos muros institucionais, além do reconhecido avanço teórico e político que as abordagens sobre a formação dos assistentes sociais ganharam no final deste século, particularmente face à atuação da Associação Brasileira de Ensino e Pesquisa (ABEPSS).

Entretanto, tal realidade amplia-se, segundo Almeida (2000a, p.20), pelos avanços teóricos de discussão da profissão em torno das políticas sociais como campo privilegiado da ação profissional e pela articulação política da categoria com movimentos sociais para a construção de um novo projeto societário pela conquista da cidadania.

Embora o trabalho do assistente social na educação ainda não se tenha ampliado de forma expressiva no mercado de trabalho em seu aspecto teórico e interventivo, como se observa pelas pesquisas, documental e de campo, o profissional tem realizado um trabalho que não se restringe à escola, com o denominado Serviço Social Escolar, mas vem passando por um processo de reconhecimento da profissão com seu trabalho fundamental nas secretarias de educação municipal e estadual mediante o assessoramento na elaboração da política educacional. E, como exemplo, tem-se o Projeto "Político Instrumental", desenvolvido pelo Serviço Social na Secretaria de Estado da Educação e Superintendência do Ensino Especial no estado de Goiás, de assessoria e consultoria para a educação especial.

Mesmo que seja uma imposição da legislação, a LDBEN, na adequação a outros projetos sociais para a redução de gastos públicos e para o atendimento aos problemas sociais repercutidos na escola, pode ser concebida como um avanço o trabalho dos assistentes sociais nessa área, vista como possibilidade de reflexão da ampliação do conceito de educação hoje, das instituições de ensino que recebem desde a criança até a terceira idade para os ensinamentos convencionais e 
obrigatórios, das possibilidades de desenvolvimento de programas e ações educacionais relacionados às mudanças da sociedade ampliando a temática da educação escolarizada como: discussões sobre a cidadania, a ética, o trabalho, a sexualidade, as drogas, a violência, o lazer, a adolescência. Temas esses que vêm fazendo parte do trabalho dos assistentes sociais que atuam e elaboram os mais diferentes programas e projetos institucionais. Essa realidade expressa os limites e os desafios da escola e dos profissionais da educação em trabalhar efetivamente com esses temas.

Os Parâmetros Curriculares Nacionais, criados pelo MEC a partir 1998, para a educação básica buscaram expressar os avanços do ensino, propondo uma nova forma de educar alunos para o novo milênio, aproximando o que se ensina na sala de aula do cotidiano dos alunos e do mundo nos dias de hoje, trazem os chamados temas transversais que são: ética, saúde, meio ambiente, pluralidade cultural, orientação sexual, trabalho e consumo. Não são novas matérias, mas assuntos que devem permear as disciplinas ministradas aos alunos durante o ano letivo. Tais parâmetros revelam uma educação antidemocrática, alienante e controladora pelo sistema vigente, a fim de padronizar a educação no Brasil. Não conseguiram sair do papel e expressaram o despreparo e o desinteresse dos educadores em incorporar esses temas a sua rotina de ensino.

Nessa deficiência é que muitos assistentes sociais foram incorporados às secretarias de educação municipal, no ensino básico, como mostram as pesquisas, por meio de projetos de extensão compreendendo a política de período integral, trabalhos de atendimento direto e indireto nos espaços de educação formal com a população usuária, como os alunos e suas respectivas famílias, em projetos de assessoria e consultoria e o trabalho com os próprios professores. Tal realidade pode ser exemplificada pelo Projeto "Serviço Social Escolar" em Campo Grande, estado do Mato Grosso do Sul, vinculado à Secretaria Municipal de Educação e Cultura; o Programa Municipal de Educação Infantil da Secretaria Municipal de Porto Alegre, estado do Rio Grande do Sul (1991) com a função de um trabalho de assessoria à equipe de profissionais das escolas; o trabalho dos assistentes sociais 
nas escolas públicas de Campina Grande, estado da Paraíba (1980); e nas escolas públicas e privadas do município de Natal, no estado do Rio Grande do Norte (1999).

Por meio dessa inserção na educação, tem-se um campo de atuação promissor e estratégico, pois é possível refletir a natureza política e profissional da função social da profissão em relação às estratégias de luta pela conquista da cidadania através da defesa dos direitos sociais por meio das políticas sociais (Almeida, 2004, p.3).

Continua Almeida (2004, p.3):

A política educacional aparece no cenário das preocupações profissionais hoje de uma forma diferenciada da que tínhamos há alguns anos. Não se trata mais de uma aproximação saudosista quanto ao campo de atuação profissional que minguou com tempo, mas de um interesse ancorado na leitura do papel estratégico que esta política desempenha do ponto de vista econômico, cultural e social. As mudanças ocorridas ao longo das últimas três décadas do século XX no mundo de produção capitalista forma decisiva para um conjunto diversificado de requisições ao campo educacional.

A ação conjunta dos assistentes sociais com o campo da educação, mediada pelos programas e projetos socioeducativos, possibilita aos profissionais atuar dentro da política educacional, com questões que lhes são centrais, como a formação permanente dos educadores e com a ampliação das práticas educacionais e pedagógicas em uma perspectiva curricular e não mais com uma visão complementar ou paralela.

$\mathrm{E}$, hoje, entendem-se práticas curriculares inseridas em um contexto histórico, social e cultural que buscam a qualidade da educação e do ensino, em processos de aprendizagem para os alunos (Sacristán, 2000, p.15-6).

A organização da categoria profissional tem empreendido várias iniciativas no que tange à regulamentação do Serviço Social na Educação e, especificamente, um Serviço Social Escolar. Recentemente, em 2003, tramitava na Câmara dos Deputados (ainda aguarda 
aprovação) um Projeto de lei que defende a presença do assistente social na educação básica. É um tema que vem ganhando espaço no legislativo, como vem ocorrendo tanto no nível federal, quanto no plano estadual e municipal, o que indica um certo grau de reconhecimento e de necessidade (conforme apresentado nesse capítulo). Não obstante, considerando a visão limitada dessas propostas e do real conhecimento da profissão de Serviço Social, por parte dos legisladores e profissionais da educação, esse nível de ensino é, muitas vezes, o único ao qual se tem acesso e uma possibilidade de expansão como frente de trabalho para o assistente social (Backx, 2008, p.121).

É importante que, diante dessa conquista de espaços profissionais, no campo da educação, o assistente social participe ativamente da construção desse momento histórico, pois conhecedor de sua trajetória nesse campo e dos profissionais da educação, deverá estrategicamente buscar alianças com esses próprios educadores, sobretudo nos espaços de debate e de organização que lhes são próprios, como as universidades, as associações acadêmicas e os sindicatos.

Dessa forma é necessário que a categoria, representada pelos Conselhos Federal (CFESS) e Regional (Cress) de Serviço Social, priorizem movimentos e organizações temáticas para conhecer todos os seus profissionais e respectivos trabalhos realizados direta e indiretamente no campo da educação. E assim estabelecer um plano estratégico para um trabalho profissional orgânico, rompendo com ações e práticas profissionais isoladas.

Outro aspecto a ser considerado pelos profissionais de Serviço Social na inserção em determinadas políticas sociais (setoriais) não consagradas em termos de mercado de trabalho, como é o caso da assistência social, é pensar que a atuação dos assistentes sociais na política educacional requer muito conhecimento, competência, criatividade, ousadia do profissional na compreensão da dinâmica e da complexidade desse campo de atuação do Estado e da sociedade civil. É entender os diferentes níveis e modalidades de educação de ensino, os papéis incorporados pelos diversos profissionais da educação como outrora, autoridades máximas e legítimas do conhecimento, e consequente dispensa de outros profissionais que comporiam um trabalho 
interdisciplinar, inclusive o assistente social. É ainda importante reconhecer que a "política educacional é uma das expressões das disputas protagonizadas pelos sujeitos sociais no campo da cultura, mas não encerra todas as particularidades da educação enquanto dimensão da vida social”. (Almeida, 2004, p.2).

Afirma ainda Almeida (idem, p.2-3) que

Os assistentes sociais devem, ao mesmo tempo, tomar a política educacional como um modo historicamente determinado de oferta e regulação dos serviços educacionais que organiza diferentes formas de trabalho coletivo e modalidades de cooperação entre os profissionais que atuam nesta área, como considerar a educação como um fenômeno social, cujas práticas e seus sujeitos envolvem processos que embora se relacionem com a política educacional a ela não necessariamente se inscrevem. Pensar a educação para além da política educacional é, deste modo, uma outra exigência posta aos assistentes sociais e que requer um olhar sobre a própria dimensão educativa de sua intervenção como constitutiva desses processos mais amplos e não necessariamente vinculada a essa área de atuação do Estado via política social.

Essa tarefa fundamental ao exercício profissional de refletir a educação em sua dimensão mais ampla tem contribuído para o entendimento dessa política social como tarefa vasta e complexa, pois envolve a formação dos cidadãos em seus diversos aspectos como: social, econômico, político, cultural, intelectual e psicológico.

A política educacional reflete as expressões da questão social, impondo desafios aos sujeitos que participam de seu planejamento, da implementação, da execução e apresenta demandas ao Serviço Social.

Segundo o Parecer Jurídico 23/00 de 22 de outubro de 2000 do CFESS, ao assistente social está sendo solicitado colaborar de forma consistente e efetiva com o processo de planejamento, de elaboração e de implementação da política educacional, das seguintes formas: no enfrentamento dos fatores sociais, culturais e econômicos que interferem no processo educacional; na cooperação da efetivação 
da educação como direito e como elemento importante à cidadania; na elaboração e execução de programas de orientação sociofamiliar, visando prevenir a evasão, a qualidade do desempenho do aluno; na realização da pesquisa socioeconômica e familiar para caracterização da população escolar; na participação em equipes interdisciplinares (e/ou mutidisciplinares), por meio da elaboração de programas e projetos que objetivem orientar, prevenir e intervir nas realidades: da violência, do uso de drogas, do alcoolismo, de doenças infectocontagiosas e demais questões de saúde pública; na realização dos instrumentais técnico-operativos como: visitas domiciliares, estudos e pareceres sociais, plantões sociais, atendimentos diversos para a intervenção na realidade educacional; na busca da integração das políticas sociais como a saúde, educação, assistência social, a atenção às crianças, ao adolescente, ao jovem, à terceira idade e outras, com vistas ao encaminhamento e ao atendimento das necessidades do trinômio: família, escola e comunidade; na possibilidade de uma formação e qualificação permanentes junto aos profissionais da educação, visando ampliar as práticas pedagógicas no atendimento às demandas do cenário nacional e globalizado; na produção de estudos acadêmicos, materializando os conhecimentos teóricos e metodológicos das experiências e das reflexões do Serviço Social e da Educação; na prestação da assessoria às equipes profissionais da área da educação; na supervisão e na coordenação de grupos de estágio em Serviço Social na área da educação; na inserção do profissional nos espaços de educação formal (escola) e não formal (projetos socioeducativos).

Nessa perspectiva de atuação profissional no campo da educação, são inúmeras as possibilidades de intervenção do assistente social e não se esgotam aqui.

Em suma, mediante essas reflexões, cabe ao assistente social a tarefa de traçar objetivos e finalidades a sua ação de forma crítica e consequente, a partir das determinações gerais e particulares de seu campo profissional. Dessa forma, é fundamental que tenha como parâmetro da ação profissional em suas diferentes dimensões, o Projeto Ético-Político-Profissional. 


\section{O assistente social na Escola: uma demanda necessária}

Conforme já abordado, o Serviço Social teve um grande destaque na educação, ou seja, marcou presença ao longo de sua existência, especialmente no ensino formal, e, mais recentemente, na educação não formal por meio dos projetos socioeducativos, no ensino superior, na elaboração de diretrizes políticas para a educação, na assessoria a projetos educacionais, nos conselhos de educação, e hoje intervém para assegurar a educação como direito social a toda a população. Sem dúvida, a escola tornou-se um espaço importante e fundamental de atuação do assistente social, por ser ela espaço de inclusão social, garantindo a universalidade e a qualidade de seu atendimento e instância de gestão democrática, reconhecendo a importância e necessidade de viabilizar diferentes formas de participação da comunidade, em seu processo de organização e de funcionamento.

$\mathrm{O}$ direito à educação, assim como o acesso ao ensino formal e a permanência na escola com qualidade tem sido exigências legais reiteradas, seja na Constituição Federal de 1988, no Estatuto da Criança e do Adolescente de 1990 e na Lei de Diretrizes e Bases da Educação Nacional de 1996, dentre outras, tendo como objetivo o pleno desenvolvimento da criança e do adolescente para o exercício da cidadania (art. 53 da Lei 8.069/90), a preparação para o trabalho e sua participação na sociedade.

A escola é uma das instituições mais presentes no cotidiano dos indivíduos e da comunidade; ela tem a tarefa de preparar membros "jovens" para sua inserção futura na sociedade e para o desempenho de funções que possibilitem a continuidade da vida social. Ela desempenha um papel importante na formação do indivíduo e do futuro cidadão.

Cabe à escola a obrigação de ensinar os conteúdos específicos de áreas do saber, escolhidos como fundamentais para instrução de novas gerações. Deve criar um ambiente de respeito, de confiança e de responsabilidade a fim de que o cidadão possa percorrer dignamente sua trajetória na sociedade, construindo relações humanas estáveis, amorosas e servidoras do bem comum. 
Afirma Demo (2000b, p.59) que

A qualidade da educação consiste numa escola voltada para a cidadania, onde assume o compromisso de gestar nos alunos o saber pensar e o aprender a aprender, de teor político. Orienta-se, no sentido pedagógico, para formação do sujeito crítico e criativo, capaz de história própria. A educação básica de qualidade ensina a ler, escrever e contar, para podermos ler a realidade politicamente, descobrir que somos vítimas de privilégios de minorias, surpreender nossa miséria como produto histórico e descortinar alternativas que dependem sempre, em primeiro lugar, dos próprios excluídos. A qualidade da educação depende da qualidade dos professores e do desempenho dos alunos.

Em um âmbito geral, a educação é fundamental para a humanização e a socialização do homem. Pode-se dizer que se trata de um processo que dura a vida inteira, e que não se restringe à mera continuidade, mas supõe a possibilidade de rupturas para as quais a cultura se renova e o homem faz a história.

Nos últimos anos, a educação no Brasil passou por mudanças, ocupando um lugar de destaque no conjunto das ações governamentais federais que redesenham hoje a arquitetura institucional e o papel do Estado brasileiro com a LDBEN. Mudanças essas vinculadas às funções econômicas e ideológicas, estratégicas no atual estágio de desenvolvimento do capitalismo: a garantia de uma formação técnica flexível, adequada às exigências dos novos padrões de produção e de consumo e às variações do mercado de compra e venda da força de trabalho, assim como a garantia de uma formação ideologicamente funcional ao paradigma da empregabilidade.

Na Carta Constitucional de 1988, os programas de atendimento ao educando são concebidos como deveres do Estado para garantir a universalização do ensino fundamental, visando ao pleno desenvolvimento da pessoa para o exercício da cidadania e à qualificação para o trabalho. E no que diz respeito à concepção, princípios e fins da educação, a LDBEN repete a lógica Constitucional, afirmando 
sua abrangência para além da casa e da escola e sua vinculação com o mundo do trabalho.

Diante dessa realidade, pode-se afirmar que a característica mais grave deste campo da política social é a não universalização do acesso da população à educação escolarizada, decorrente, sobretudo, de um confronto de interesses por uma cultura política excludente e elitista, que não consegue incorporar a participação das classes subalternas nos ciclos de alternância do poder e de desenvolvimento econômico (Coutinho, 1992).

A tarefa de educar visa à formação integral, personalizada, harmônica, integrada e crescente da pessoa humana; e visa à formação do homem novo, inserido em uma ordem social nova e em um mundo novo. Portanto, o marco referencial da educação é a pessoa humana do aluno, e não apenas seus rendimentos intelectuais ou seus resultados quantificados em notas ou conceitos. O aluno é a pessoa inserida em um projeto novo de sociedade, e um projeto novo que aponta para novas relações sociais. Conforme já discutido, o ensino de qualidade, antes, começa com uma legislação de qualidade, com uma escola de qualidade, com seus objetivos, estratégias, programas, conteúdos, metodologia e convivência humana e humanizadora, socializada e socializadora; com um quadro de professores comprometidos com a causa do ser humano, com a escola, seus fins e seus princípios e com sua qualificação permanente.

É necessário entender a educação não apenas como fonte do saber, do conhecimento humano, do entendimento e da compreensão; não apenas como processo necessário que encaminha a pessoa humana para uma profissão e para vencer na vida, em que há competência e concorrência, vencedores e vencidos. A educação, acima de tudo, deve ser compreendida como experiência de mudanças e como fonte de transformação das mentalidades, das relações sociais, dos regimes sociais e da superação das lutas por "interesses", mas por causas libertadoras.

Nesse sentido, é importante considerar alguns questionamentos, incertezas e desconhecimentos sobre o papel do assistente social na escola que ocorrem por parte dos profissionais do social e da educação. 
A imputação legal de mais um profissional na escola, sem argumentações fundadas em uma história de política educacional e uma reflexão conjunta com os profissionais da educação, tem muitas vezes revelado uma invasão de espaço e uma sobreposição de funções e habilidades nas ações educativas que objetivam a construção da cidadania. É ainda muito negativo para o Serviço Social vincular a presença do assistente social à consolidação de práticas assistencialistas, paliativas e emergenciais no universo escolar.

No cenário nacional da educação, que apresenta avanços tecnológicos e novos paradigmas sobre a educação ao Serviço Social, é muito importante refletir os motivos que demandam a presença do assistente social na educação e não só expressar de um desejo profissional em ocupar mais um campo.

Um aspecto relacionado à presença do assistente social na escola é o aumento dos programas e projetos sociais governamentais em todas as esferas, de enfrentamento da pobreza e da garantia de uma renda mínima, o que exige a inserção e a participação no ensino regular das crianças e adolescentes das famílias atendidas. Tem contribuído para um trabalho conjunto das secretarias municipais em atenção ao ensino formal.

Outro aspecto a considerar são as refrações da questão social que se manifestam no cotidiano escolar e interferem no processo de ensino e aprendizagem, como a evasão escolar, o baixo rendimento, a indisciplina, a agressividade do aluno e de profissionais, o uso de drogas, a violência, o preconceito, o despreparo dos educadores, exigindo diálogo e aproximação dos profissionais da educação com os setores e as categorias profissionais das demais políticas sociais: a saúde, a segurança, a assistência social, a cultura, ganhando contornos específicos a partir das realidades regionais e municipais do País.

A articulação entre as políticas sociais e o campo educacional tem sido uma tendência contemporânea para o enfrentamento das questões sociais presentes hoje na sociedade brasileira. Os percursos das políticas sociais no Brasil sempre foram marcados por traços assistencialistas, tutelares e autoritários e, além de não conseguirem 
alterar o quadro de pobreza e de exclusão no País, só contribuíram para o aumento da concentração de renda. Portanto, entendê-las sob a lógica da regulação social em um mundo globalizado, requer apreender a quem se destinam e quais estratégias de enfrentamento são possíveis em um contexto tão complexo (Almeida, 2003, p.7).

O profissional deve ter claro o objetivo final de sua ação de forma crítica e consequente, a partir das determinações mais gerais e particulares de seu campo profissional. Nesse sentido, sua ação profissional no espaço escolar deverá ser fundamentada em seu compromisso ético e político.

A atuação do Serviço Social na escola tem revelado muitas experiências positivas, possibilitando a conquista do espaço, por meio de uma intervenção interdisciplinar, valorativa e reflexiva. São muitas as experiências nos municípios brasileiros onde o Serviço Social atua nas escolas de ensino básico, médio e superior e educação de jovens e adultos, já apresentados aqui.

Em um passado muito próximo, as primeiras atuações dos assistentes sociais na rede de ensino tinham essencialmente um caráter funcionalista, que atendia as práticas de ajustamento comportamental dos alunos às normas da instituição. Mas, hoje, o pensar da práxis profissional no contexto de uma crise estrutural do sistema educacional brasileiro e do acesso à escola não ter se universalizado efetivamente, tem exigido do profissional a proposição de novas formas de atuação.

O papel do assistente social no espaço escolar tende a ser conhecido e aceito pelo coletivo escolar, à medida que ele constitui competências e habilidades em respostas às demandas do processo educativo. Nesse sentido, o Projeto Político Pedagógico da escola determina os fundamentos, os princípios e os objetivos do processo ensino-aprendizagem, impossibilitando a justaposição de funções e uma prática interdisciplinar efetiva.

Dessa forma, faz-se necessário que o assistente social, ciente de seu trabalho na instituição educacional, reflita toda essa realidade existente, a fim de conhecer as forças políticas existentes, os interesses escusos, interrogue-se a serviço de quem a escola e o ensino então, 
qual o tipo de escola está sendo desenhado no cenário brasileiro e assim construa uma intervenção pautada na garantia de direitos àqueles que são rechaçados pelo ideário neoliberal.

\section{O mercado de trabalho e as respostas profissionais na área da educação}

Conforme abordado neste capítulo, pode-se afirmar que a área da educação tem sido um grande desafio para o assistente social. São poucas as definições, e a construção do trabalho hoje é contínua, visto que a realidade atual impõe a necessidade de alternativas de trabalho frente às demandas da escola, pois esta se vê muitas vezes impotente na resolução dos mesmos.

O espaço do Serviço Social no cenário educacional ainda é pouco reconhecido, mas vem sendo gradativamente conquistado. Embora de forma gradativa, a profissão tem ampliado sua atuação por meio das escolas públicas e privadas, assessorias na elaboração e implementação das políticas sociais, especialmente a educação, nos projetos educacionais de extensão à comunidade, nos conselhos escolares e municipais de educação, nas equipes de formação e orientação aos profissionais da educação.

A partir dos avanços que vêm ocorrendo do trabalho dos Assistentes Sociais na educação brasileira, torna-se evidente cada vez mais que é importante e fundamental a intervenção desses profissionais na política educacional e na gestão escolar especialmente na "proposta pedagógica que insere a escola na realidade e a realidade na escola como elemento fundamental para o ensino e aprendizagem" (Alessandrini, 2001, p.55).

Muitas transformações fazem-se presentes no cenário mundial da globalização, obrigando ao profissional novas perspectivas e novas interpretações, nesse contexto de desenvolvimento econômico e social. Para isso, faz-se necessário um profissional crítico, científico (pesquisador), competente para uma intervenção e gestão do desenvolvimento social, com identidade profissional e cultural, 
comprometido com o desenvolvimento da sociedade e a defesa dos direitos humanos e sociais.

Diante das novas configurações da sociedade contemporânea, tem-se um rápido crescimento e ampliação da inserção do assistente social em novos campos de trabalho legitimados pelo mercado de trabalho, expondo quase sempre, o profissional a suas determinações.

A globalização econômica, característica do capitalismo contemporâneo, determina mudanças fundamentais no mundo do trabalho, alterando as formas de produtividade, a organização e as relações de trabalho. Tais mudanças têm implicado aumento da exploração da força de trabalho e a consequente perda de direitos pelos trabalhadores, com agravamento da questão social.

Nesse sentido, o Serviço Social tem se confrontado com novas exigências para a formação profissional e o exercício da profissão, como a busca de um conhecimento teórico-metodológico consistente, proporcionando aos profissionais uma compreensão clara da realidade social e a identificação das demandas e possibilidades de ação profissional que esta realidade apresenta, o compromisso com a realização dos princípios ético-políticos estabelecidos pelo Código de Ética e a capacitação técnico-operacional. Com esse quadro, urge um novo olhar, um pensar e um fazer profissional do assistente social, consolidando o projeto ético-político, pautado nos princípios da justiça social, da igualdade e da liberdade como conquista da cidadania.

Esse processo, afirma Iamamoto (2001, p.20), exige do assistente social uma participação enquanto

um sujeito profissional que tenha competência para propor, para negociar com a instituição os seus projetos, para defender o seu campo de trabalho, suas qualificações e funções profissionais [...] desenvolver sua capacidade de decifrar a realidade e construir propostas de trabalho criativas e capazes de preservar e efetivar direitos, a partir de demandas emergentes no cotidiano. [...] e buscar apreender o movimento da realidade para detectar tendências e possibilidades nela presentes. 
No que diz respeito à educação, tem se revelado como inegável campo de atuação do profissional social, pois tem sido o alvo de muitas contradições, de críticas, de acordos políticos nacionais e internacionais, desfigurando seu papel fundamental de igualdade, de participação, de acesso e de direito de todo o cidadão. Desencadeiamse problemas de ordem social ratificando, muitas vezes, a impotência dos profissionais da educação, o despreparo destes e a falta de compromisso na busca de alternativas e soluções para o enfrentamento da precarização do ensino e dos conflitos internos existentes.

Segundo Frigotto (2000, p.204), o campo educacional é direito não mercantilizável e implica um rompimento com o velho, o fragmentário, e uma ação humana organizada, isso porque

A tradição de um Estado clientelista, paternalista e autoritário, no caso brasileiro, obnubila, no presente, amplos setores progressistas e dificulta a superação de uma visão moralista e reducionista de Estado. Isto se manifesta nas perspectivas maniqueísta do contra ou a favor do Estado. O problema é de outra ordem. A possibilidade de avanço alternativo ao neoliberalismo na educação implica trazer o embate, a disputa, o conflito, no plano da esfera pública. Implica mais sujeitos coletivos com densidade analítica e organizativo-política para dar densidade ao embate.

A escola carece da definição de um papel e de sua identidade no contexto social, político e histórico. E essa construção depende de um movimento interno, ou seja, do interesse das pessoas envolvidas em construir a identidade da escola e, consequentemente, a construção da identidade de seus educadores e o grau de conhecimento da escola.

Afirma Frigotto (2000, p.203) que o Brasil assiste à banalização da escola pública e é preciso dar uma resposta coletiva:

As propostas educacionais como alternativa no campo educativo expõem os limites do horizonte da burguesia e, em casos como o brasileiro, sobredeterminados por uma burguesia atrasada, elitista e despótica. Isto se materializa de forma exemplar no embate em torno 
da educação no processo constituinte (1988) e, mais especificamente, no processo em curso há mais de 5 anos da LDB (1989-1995). O discurso da modernidade, na prática, esconde o profundo atraso histórico. O que vem ocorrendo por inúmeros disfarces, convênios, cooperativa, etc., é a privatização crescente e o desmonte da escola pública.

Dessa forma, faz-se necessário conhecer o novo público atendido pelas instituições escolares, construir novos projetos pedagógicos, integrar ensino e realidade do aluno, melhorar a formação e a remuneração dos professores e educadores, buscar melhores equipamentos e estruturas escolares, trabalhar a construção da interdisciplinaridade profissional a partir do diálogo, da integração dos saberes, da troca de informações e conhecimentos e da busca de uma visão integral do sujeito.

Assim, cada vez mais os profissionais de diferentes áreas, especialmente o Serviço Social têm buscado uma atuação interdisciplinar no campo educacional, no qual possam construir paulatinamente um novo saber colaborando para que as pessoas se tornem sujeitos de suas histórias.

A interdisciplinaridade, para Fazenda (2003, p.75) não é uma categoria de conhecimento, mas de ação, por isso,

Entendemos por atitude interdisciplinar uma atitude ante alternativas para conhecer mais e melhor; atitude de espera ante os atos não consumados, atitude de reciprocidade que impele à troca, que impele ao diálogo, ao diálogo com pares idênticos, com pares anônimos ou consigo mesmo, atitude de humildade ante a limitação do próprio saber, atitude de perplexidade ante a possibilidade de desvendar novos saberes; atitude de desafio, desafio ante o novo, desafio em redimensionar o velho; atitude de envolvimento e comprometimento com os projetos e com as pessoas neles envolvidas; atitude, pois, de compromisso em construir sempre da melhor forma possível; atitude de responsabilidade, mas sobretudo, de alegria, de revelação, de encontro, enfim, de vida. 
Nesse sentido o conhecimento interdisciplinar deve ser construído reciprocamente e por meio de comunicação e de contribuição de cada ciência, não havendo sobreposição de nenhuma delas, mas preservando a integridade de seus métodos e de seus conceitos.

A escola (educação) em seu compromisso de organizar o trabalho no sentido de torná-lo mais tangível para aqueles que a ela têm direito, de possibilitar o acesso do indivíduo à cultura de uma sociedade e de um país, pelo direito do cidadão dizer sua voz e ser ouvido pelos outros e o Serviço Social em seu compromisso de efetivar direitos sociais intervindo nas expressões da questão social, tanto na atuação direta nas unidades escolares, como nas atividades de gerenciamento e de planejamento da política educacional, poderão juntos viabilizar a concretização da universalização do acesso ao ensino e a superação das desigualdades sociais. 


\section{5 \\ A PESQUISA DE CAMPO}

"A inteligência de uma equipe é maior do que a soma da inteligência de seus membros".

Peter Seng

\section{Percurso metodológico}

A pesquisa de campo descrita neste capítulo propõe uma integração dos dados obtidos pela pesquisa bibliográfica, documental (apresentada no capítulo 4) e de campo.

Segundo José Filho (2006, p.64) "o ato de pesquisar traz em si a necessidade do diálogo com a realidade a qual se pretende investigar e com o diferente, um diálogo dotado de crítica, canalizador de momentos criativos". A tentativa de conhecer qualquer fenômeno constituinte dessa realidade busca uma aproximação, visto sua complexidade e dinamicidade dialética.

Porém, não existe pesquisa sem o apoio de técnicas e de instrumentos metodológicos adequados, que permitam a aproximação ao objeto de estudo.

Nesse sentido, para Demo (2002, p.16), 
Em termos cotidianos, pesquisa não é um ato isolado, intermitente, especial, mas atitude processual de investigação diante do desconhecido e dos limites que a natureza e a sociedade nos impõem. [...] Faz parte do processo de informação, como instrumento essencial para a emancipação.

Nesse contexto científico, a pesquisa possui aspectos teóricos, metodológicos e práticos, transpondo o reducionismo do empirismo. A realidade é interpretada a partir de um embasamento teórico, sem a pretensão de desvendar integralmente o real e possui um caminho metodológico a percorrer com instrumentos cientificamente apropriados (José Filho, 2006, p.65).

A presente pesquisa traz como objeto de estudo o Serviço Social na Educação Municipal de Barretos/SP.

Dessa forma, visa compreender para explicar a importância do Serviço Social na Política Educacional.

Com base em tais objetivos, optou-se por uma pesquisa qualitativa que possibilita a leitura da realidade, pois, segundo Chizzotti (1995, p.79),

A abordagem qualitativa parte do fundamento de que há uma relação dinâmica entre o mundo real e o sujeito, uma interdependência viva entre o sujeito e o objeto, um vínculo indissociável entre o mundo objetivo e a subjetividade do sujeito. O conhecimento não se reduz a um rol de dados isolados, conectados por uma teoria explicativa; o sujeito-observador é parte integrante do processo de conhecimento e interpreta os fenômenos, atribuindolhes um significado. O objeto não é um dado inerte e neutro, está possuído de significados e relações que sujeitos concretos criam em suas ações.

A pesquisa inicia-se pela fase exploratória, que consiste em uma caracterização do problema, do objeto, dos pressupostos, das teorias e do percurso metodológico. Não busca resolver de imediato o pro- 
blema, mas caracterizá-lo a partir de uma visão geral, aproximativa do objeto pesquisado. Tal fase fez-se necessária por se tratar de "um tema pouco explorado, tornando-se difícil sobre ele formular hipóteses precisas e operacionalizáveis" (Gil, 2000, p.43).

Confirma Gil "que as pesquisas exploratórias têm como principal finalidade desenvolver, esclarecer e modificar conceitos e ideias, tendo em vista a formulação de problemas mais precisos ou hipóteses pesquisáveis para estudos posteriores" (1999, p.43), ou seja, estabelecer maior familiaridade com o problema.

Assim sendo, esse estudo envolveu um levantamento bibliográfico que perpassou toda a elaboração deste trabalho, com o propósito de compreender para explicar a realidade estudada. Nesse sentido, foram utilizados diversos autores da educação, da sociologia, da filosofia e específicos do Serviço Social, na busca de conhecer a estrutura educacional imposta no Brasil, seus paradigmas atuais e o legado histórico da profissão do Serviço Social, sob o signo da alienação. Foi capaz de transpor os limites da consciência histórica e de pactuar com a construção de um país democrático, com a ampliação da cidadania e a intervenção por meio de políticas sociais includentes, especialmente a educação.

A pesquisa de campo foi realizada na Secretaria Municipal de Educação do Município de Barretos, interior do estado de São Paulo. Segundo Gonsalves (2001, p.67),

A pesquisa de campo é o tipo de pesquisa que pretende buscar a informação diretamente com a população pesquisada. Ela exige do pesquisador um encontro mais direto. Nesse caso, o pesquisador precisa ir ao espaço onde o fenômeno ocorre, ou ocorreu e reunir um conjunto de informações a serem documentadas [...].

Tal pesquisa contou com uma amostra não probabilística, intencionalmente constituída pelo Serviço Social da Secretaria Municipal de Educação. A partir dessa amostra, foram definidos três sujeitos, no universo estudado, conforme segue na tabela a seguir. 
Tabela 1 - Amostra do universo e sujeitos da pesquisa

\begin{tabular}{c|c|c}
\hline $\begin{array}{c}\text { Secretaria Municipal } \\
\text { de Educação de } \\
\text { Barretos/SP }\end{array}$ & Cargo Atual & Sujeito \\
\hline 1 & Secretária Municipal de Educação & Rosa \\
\hline 2 & Supervisora Geral de Educação Infantil & Orquídea \\
\hline 3 & Assistente Social & Violeta \\
\hline
\end{tabular}

Fonte: Investigação de campo realizada pela pesquisadora/2008

A definição dos sujeitos da pesquisa foi realizada mediante critérios determinados pela pesquisadora e são os seguintes: profissionais que trabalham diretamente com a assistente social e respondem por cargo de chefia e a profissional assistente social que atua na Secretaria da Educação. Vale ressaltar que a Secretaria da Educação não conta com nenhum departamento específico de Serviço Social, somente o profissional atuando nos Centros Municipais de Educação Infantil Cemeis, tendo como chefia direta a Secretária Municipal de Educação e a Supervisora Geral da Educação Infantil. A caracterização dos sujeitos da pesquisa será apresentada na Tabela 3.

É importante destacar que Barretos conta com um trabalho incipiente do Serviço Social na Secretaria Municipal de Educação, atualmente somente um profissional assistente social desenvolve o trabalho nessa política social. Embora exista a presença desse profissional desde 2003, recorte temporal dessa investigação de 2003 a 2008, não possui uma estrutura necessária para um trabalho de qualidade, representativo e reconhecido na secretaria junto aos profissionais da educação.

O relato abaixo confirma a realidade:

São 21 Cemeis, 2,8 mil crianças e realmente uma assistente social não dá para fazer um acompanhamento de perto e a gente acaba atendendo aqueles casos com maior prioridade, maior urgência, maior necessidade e que venha apresentar alguma distorção no comportamento, alguma alteração no comportamento, alguma dificuldade social, muitas vezes a gente até atende onde a professora encontra dificuldade e, muitas vezes é pedagógico, mas a assistente social acaba influenciando ou interferindo, indo a pedido da diretora 
e da própria professora nesses casos [...] não existe equipe, mas é um trabalho individualizado. (Violeta)

Entretanto, caracteriza-se como um trabalho em construção, pois na visão dos sujeitos da pesquisa o trabalho precisa ser ampliado na Secretaria Municipal de Educação, onde atua a profissional. Conta ainda com uma parceria por meio de convênio com o curso de Serviço Social do Centro Universitário da Fundação Educacional de Barretos pelo estágio de campo supervisionado, tendo a pesquisadora como supervisora, desde 2007 e o trabalho de uma organização não governamental de Barretos, cuja assistente social desenvolve um trabalho com as famílias, iniciado em 2008 e subsidiado financeiramente com recursos desse município, a partir desse ano.

Hoje nós temos parceria com a Unifeb, o curso de Serviço Social que atua junto conosco e temos tido a felicidade de receber só elogios a esses trabalhos profissionais e estamos pensando, depois daquele Fórum que participamos como poderíamos trazer o Serviço Social de maneira mais formal para a Educação Municipal de Barretos. Porque hoje temos a parceria, mas gostaríamos de estender essa parceria e realmente ter funcionários do Serviço Social atuando dentro da educação [...] eu acho que teria que ter, deveria ter uma equipe de dez assistentes sociais, teríamos um coordenador nessa equipe, acho que os profissionais teriam que fazer uma formação, porque tudo é muito rápido, gira muito rápido, e o trabalho é importante. (Rosa)

Junto a essa realidade investigada, a pesquisadora buscou uma realidade que caracterizou como complementar: o trabalho do Serviço Social na Secretaria Municipal de Educação de Osasco/SP. O objetivo é contribuir com novas propostas de atuação da profissão de Serviço Social na Educação de Barretos, uma vez que esse universo pesquisado conta com um número reduzido de assistentes sociais e busca uma ampliação dessa atuação por meio de uma nova visão e divulgação da profissão de Serviço Social. Com isso, nos anos de 2006 e 2007, foram realizadas as entrevistas com os profissionais da equipe interdisciplinar que trabalham com as unidades escolares de educação infantil e ensino fundamental de Osasco. Foram selecio- 
nados os profissionais que possuem cargo de chefia e que respondem pela política educacional no município: assistente social que é a coordenadora da equipe interdisciplinar, a diretora do departamento das escolas de ensino básico e a secretária municipal de educação.

A experiência do Serviço Social na Secretaria Municipal de Educação do Município de Osasco, com aproximadamente oito anos de trabalho, contribuiu para uma transposição dessa experiência para o município de Barretos. Significou um acréscimo ao conhecimento, podendo-se afirmar que por meio da experiência de Osasco, será possível analisar e traçar novas propostas, sugestões e perspectivas para a intervenção do Serviço Social na Educação Municipal de Barretos. É importante considerar que não se trata de um trabalho finalizado, perfeito e protótipo de intervenção profissional, porém, o município de Osasco, escolhido pela pesquisadora dentre vários do estado de Saulo Paulo que desenvolvem um trabalho propositivo, criativo e diferenciado do Serviço Social junto à educação do Brasil, teve como proposta inicial do orientador que foi convidado pelo município para refletir sobre a atuação do Serviço Social na Educação.

a vinda do Prof. Canôas aqui em Osasco, na ocasião que proferiu a palestra, foi exatamente ajudar-nos a construir essa história do Serviço Social e aqui também temos essa preocupação com a efetividade do trabalho, a eficácia, a importância, acho que estamos tendo um fator muito positivo que é aceitação nesse momento. Mas os profissionais não podem perder de vista que devem fazer um trabalho em conjunto e mostrarem a sua importância. Na verdade aqui em Osasco é o que mais nos preocupa, se o profissional vai dar conta disso, até respaldar essa expectativa que existe. Nós estamos vivendo um momento ímpar em Osasco. Nesse sentido acho que é muito importante essa iniciativa e o objeto da tua tese, pois vai contribuir para a Academia e para ressaltar a importância do Serviço Social como um todo, que para mim é muito relevante. Fico feliz com os saltos de qualidade da nossa área do Serviço Social. (Margarida)

Os entrevistados foram denominados como profissionais da educação que contribuíram no conhecimento com propostas para o 
universo e o objeto de estudo pesquisados, segundo a Tabela 2. Suas falas serão acrescentas junto às falas dos sujeitos da pesquisa em todo o percurso da análise.

Como critérios de escolha, foram selecionados profissionais que ocupam cargos de chefia e estão ligados diretamente ao profissional assistente social da educação municipal e o próprio assistente social na função de coordenador da equipe interdisciplinar.

As entrevistas foram agendadas com contatos prévios, por meio de ligações telefônicas, em dias e horários estabelecidos pelos profissionais. Foram gravadas e transcritas segundo a autorização dos pesquisados. A realização ocorreu nos anos de 2006 e 2007. Foi utilizado o mesmo formulário com questões semiestruturadas, empregado nas entrevistas dos sujeitos.

Os sujeitos dessa pesquisa foram identificados por nomes de flores: Margarida, Girassol e Hortência. Suas falas registradas nas análises estarão sempre reconhecidas pela identificação do profissional. Vale destacar que os profissionais são todos do sexo feminino.

Segundo a tabela abaixo, foi traçada a caracterização dos profissionais entrevistados que contribuíram complementarmente na análise desse estudo.

Tabela 2 Caracterização dos profissionais que contribuíram no acréscimo da pesquisa

\begin{tabular}{l|c|l|l|l|c}
\hline Identificação & Idade & Escolaridade & Pós-Graduação & Cargo/Tempo & $\begin{array}{l}\text { Tempo de } \\
\text { atuação } \\
\text { profissional }\end{array}$ \\
\hline Margarida & 39 & $\begin{array}{l}\text { Superior } \\
\text { Completo/ } \\
\text { Assistente } \\
\text { Social }\end{array}$ & $\begin{array}{l}\text { Especialização em } \\
\text { Políticas Sociais }\end{array}$ & $\begin{array}{l}\text { Assistente Social/ } \\
5 \text { anos } \\
\text { Coordenadora } \\
\text { da Equipe } \\
\text { Interdisciplinar/ } \\
4 \text { anos }\end{array}$ & 15 anos \\
\hline Girassol & 55 & $\begin{array}{l}\text { Superior } \\
\text { Completo/ } \\
\text { Pedagogia }\end{array}$ & Psicopedagogia & $\begin{array}{l}\text { Secretária } \\
\text { Municipal da } \\
\text { Educação/2 anos }\end{array}$ & 30 anos \\
\hline Hortência & 52 & $\begin{array}{l}\text { Superior } \\
\text { Completo/ } \\
\text { Pedagogia }\end{array}$ & Psicopedagogia & $\begin{array}{l}\text { Coordenadora das } \\
\text { Escolas de Ensino } \\
\text { Fundamental/ } \\
2 \text { anos }\end{array}$ & 30 anos \\
\hline
\end{tabular}

Fonte: Investigação de campo realizada pela pesquisadora/2007 
Os dados da tabela acima revelam que os profissionais encontram-se diretamente ligados à educação e qualificaram-se profissionalmente nas áreas que possibilitam um maior conhecimento e envolvimento com o trabalho. Trata-se de uma grande experiência profissional, proporcional ao tempo de vida, agregando valores como a dedicação, o interesse e a realização pessoal e profissional.

O Prof. Canôas sabe que sou apaixonada pelas questões sociais; tanto que tive diversos trabalhos, Febem, Penitenciária, sou muito suspeita, sou ansiosa, às vezes sou ingênua imaginando que a gente vai transformar esta realidade social. Ficamos felizes com esta proposta de pesquisa de vocês, porque precisamos começar a discutir essa área, a educação, e revelar aos diversos profissionais, como é importante para a atuação do assistente social [...]. (Margarida)

Diante do exposto, é importante refletir que o Serviço Social ganhou destaque e relevância como profissão de intervenção na realidade social e humanista, reafirmando a significação social de uma profissão cada vez mais interventiva e investigativa, ratificando a importância de um projeto de formação profissional embasado na aquisição de novos conhecimentos teóricos e metodológicos em diferentes áreas do conhecimento da humanidade.

\section{Caracterização do campo de investigação}

O cenário dessa investigação é o município de Barretos, no estado de São Paulo, considerando em seu universo a Secretaria Municipal de Educação, este se reporta ao trabalho do profissional assistente social na educação. Dessa forma, revela-se o importante destaque neste estudo ao município.

Busca-se ressaltar alguns aspectos relevantes integrados diretamente ao objeto de estudo dessa investigação, não se pretendendo aprofundar nos dados histórico, social, econômico e cultural da cidade. 


\section{O município de Barretos ${ }^{1}$}

A fundação da cidade de Barretos data em 25 de agosto de 1854, sendo elevada a município em 10 de março de 1855. O espírito desbravador dos herdeiros dos bandeirantes paulistas impulsionou, no início do século XIX, a busca de novas terras, mais férteis e promissoras. A privilegiada localização e os fartos recursos naturais motivaram a escolha do local para o início de um povoado.

Os fundadores de Barretos chegaram à região vindos, principalmente, do sul de Minas. Atravessaram o rio Pardo, na antiga Fazenda Santo Inácio e, por volta de 1830, assentaram-se em dois núcleos: "Fazenda dos Barretos" e "Fazenda dos Marques". A primeira desenvolveu-se a partir do local onde está o atual largo do Rosário.

Por volta de 1845, as duas famílias pioneiras resolveram delimitar uma área comum que recebeu o sugestivo nome de "Patrimônio do Espírito Santo”. A mesma área já vinha servindo como referência e pousada para viajantes, particularmente comerciantes das mais diversas e distantes localidades. A delimitação motivou a construção, logo a seguir, da primeira capela e as primeiras casas começaram a surgir. A Paróquia da época organizou a divisão do "Patrimônio" em quadras e datas, formando, assim, uma "primeira planta da cidade.

O povoado começou a desenvolver-se lentamente. A densa mata que o circundava exigia sacrifícios sobre-humanos para ser removida. Um acidente natural, no rigoroso inverno de 1970, alterou substancialmente as condições de ocupação e desenvolvimento da região. Após forte geada, um grande incêndio, destruiu significativa área de florestas. Foi o chamado "Fogo de 70" que deixou calcinada enorme quantidade de terra. Com a chegada das chuvas, no lugar da antiga floresta surgiu uma rica e natural pastagem que criou condições adequadas para a criação e a engorda de gado. Inúmeras fazendas foram

1 Os dados desse item 2.1 foram retirados do site www.barretos.sp.org.br. Acesso em: 11 ago. 2008 e do livro: Zauith, Chamissi. Barretos: da origem ao núcleo histórico. Soares de Oliveira: Barretos, 1993. 
se formando e a atividade pecuária progrediu rapidamente, em toda a região, tornando Barretos um centro comercial vigoroso e próspero.

No início do século XX, importante atividade agrícola veio somarse à pecuária. A cultura do café atingiu a região. As mudanças vieram acompanhadas de um elemento historicamente ligado ao desenvolvimento do País: o imigrante europeu.

A vinda e a instalação dos europeus, particularmente italianos, alterou o ritmo de desenvolvimento, assim como o aspecto e a arquitetura da cidade. Um pouco mais tarde, chegaram os árabes e as atividades econômicas começaram a desenvolver-se também em seu aspecto urbano, unindo o aumento da produção agrícola ao crescente comércio. Foram expressão de tais transformações as novas técnicas de construção e as fachadas de edifícios que passaram a ser artisticamente trabalhados. Um gênio da época, o arquiteto Pagani, foi responsável pela qualidade e beleza do conjunto urbanístico da antiga área central.

Em 1900 e 1916, dois acontecimentos marcaram a história de Barretos e região: a chegada da ferrovia e da Companhia Frigorífica Anglo Pastoril. A ferrovia, Companhia Paulista de Estrada de Ferro impulsionou a atividade produtiva, com transporte de cargas e de passageiros. A Anglo, de propriedade dos ingleses, gerou empregos e crescimento, tanto econômico como populacional, instalando, ao lado de suas dependências industriais, a Vila Operária, um núcleo urbano.

As duas grandes guerras mundiais ocorridas entre 1914 e 1945, marcaram, significativamente, a evolução econômica de Barretos com o aumento nas exportações de carnes e enlatados. Naturalmente, os reflexos foram rapidamente sentidos em todos os setores da economia local. Entre os anos de 1940 e 1950, o progresso chegou decisivamente nos setores urbanos. Ocorreram a ampliação dos serviços públicos, pavimentações, infraestrutura de saneamento, energia elétrica e telefonia.

O comércio local passou à condição de polo do norte do estado, Triângulo Mineiro e sul de Goiás. Com a implementação do aeroporto local e a pavimentação asfáltica da rodovia de ligação com a capital consolidou-se, no final de 1950, o espírito desenvolvimentista. 
Barretos é uma cidade paulista de importante desenvolvimento no Brasil. Situa-se ao norte do estado, exatamente a $44 \mathrm{~km}$ da divisa com o estado de Minas Gerais e a 420 km de São Paulo (capital) com uma área de 1.563,6 km², Barretos está em uma altitude de 530 metros e tem clima tropical. Com uma população de 103.874 habitantes, tem uma densidade demográfica de 66,43 habitantes $/ \mathrm{km}^{2}$ (IBGE, 1999).

A cidade, hoje, apresenta bons indicadores sociais, saúde, saneamento, educação e moradia.

No transporte intermunicipal várias linhas ligam Barretos a todas as cidades da região, inclusive do Triângulo Mineiro e a outros centros mais distantes: São Paulo, Belo Horizonte, Goiânia, Brasília, Cuiabá, Campo Grande e Rio de Janeiro.

A Ferroban liga Barretos a São Paulo por ferrovia, operando em 2001 apenas com trens especiais de transporte de soja, por meio de um convênio com a empresa Cutrale/Quintela.

O Aeroporto Municipal suporta pousos e decolagens de jatos $707 / 737$, inclusive à noite.

No setor de educação, a cidade possui nove escolas estaduais de $5^{\mathrm{a}}$ a $8^{\mathrm{a}}$ séries do Ensino Fundamental, várias escolas particulares com cursos desde a pré-escola até o Ensino Médio. Barretos tem uma unidade da Fundação Paula Souza com cursos profissionalizantes, cursos supletivos, a Faculdade Integrada Soares de Oliveira com cursos de graduação e pós-graduação nas áreas de Pedagogia, Ciências Contábeis e Processamento de Dados e outras, o Centro Universitário da Fundação Educacional de Barretos com 22 cursos dentre eles, Engenharia Civil, Engenharia Elétrica com habilitações em Eletrotécnica e Eletrônica, Engenharia de Alimentos, Odontologia, Administração, Direito, Serviço Social (desde 2003) e outros e o Polo da Universidade Aberta (UNB e UFSCAR) com os cursos: Educação Física, Música, Teatro e outros.

A principal empresa barretense foi o Frigorífico Anglo (hoje Friboi) e o Frigorífico Minerva, responsáveis pela grande produção de enlatados e abates.

Na Zona de Uso Diversificado, instalaram-se primeiramente empresas beneficiadoras de látex, produtos derivados do couro, de 
embalagens plásticas, plástico injetado, cutelaria e produtos de lida na fazenda, entre outros. Poucas empresas como as indústrias de Café Paulista e Café Rodeio ficaram no antigo Distrito I. Espalhadas pela cidade, existem indústrias de chapéus, microempresas fabricantes de confecção, entre outras.

O comércio de Barretos sempre foi muito forte, constituindo-se em principal centro de compras da microrregião que se transformou na $13^{a}$ Região Administrativa do estado, composta por 18 municípios mais a sede, fomentando a instalação de um Shopping Center construído pela São Carlos Empreendimentos, ligada ao Grupo Garantia e Lojas Americanas, posteriormente adquirido pelo Grupo Carrefour, hoje em reestruturação.

Barretos continua sendo uma das regiões mais importantes para a produção de grãos do estado de São Paulo. Nos anos de 1970 e 1980, viveu uma fase de grande avanço na citricultura, quando a maioria de pequenos e médios produtores implantaram pomares em suas propriedades, que aos poucos foram sendo arrancados em função da política de preço imposta pelas fábricas de suco, que passaram a deter grandes plantações de laranja para uso próprio. A novidade ficou por conta da "heveacultura" (cultivo de seringueiras) e atualmente, o município de Barretos é um dos maiores produtores de borracha para beneficiamento. A pecuária de leite continua sem muito destaque como sempre foi. Barretos continua sendo referência em termos de inseminação artificial e, mais recentemente, em transferência de embriões.

É relevante ainda o trabalho realizado na implantação baseada no universo country e na fama da Festa do Peão de Boiadeiro, por atrair visitantes o ano todo, em consórcio com as atrações históricas e rurais do município.

A Secretaria Municipal de Educação possui hoje aproximadamente 55 unidades entre escolas, Centros Municipais de Educação Infantil e projetos socioeducativos de práticas pedagógicas em contexto não escolar, fazendo parte da política educacional de período integral, segundo o artigo 34 da LDBEN, "determina que o ensino fundamental seja progressivamente em tempo integral, a critério dos sistemas de ensino". 
Nesse cenário educacional, propõe-se e busca-se explicar uma atuação educativa e pedagógica na construção de um perfil do profissional de Serviço Social, o assistente social.

\section{Processo de coleta de dados}

Os dados foram coletados por meio de entrevistas semiestruturadas junto aos sujeitos, significando um procedimento formal de se obter informações por meio da fala dos atores sociais. Segundo Barros \& Lehfeld (2000, p.58),

a entrevista semiestruturada estabelece uma conversa amigável com o entrevistado, busca levantar dados que possam ser utilizados em análise qualitativa, selecionado-se os aspectos mais relevantes de um problema de pesquisa.

As entrevistas com os sujeitos foram registradas com o uso de MP4 e/ ou gravador, objetivando garantir a autenticidade dos depoimentos representados pela fala dos entrevistados e transcritas conforme seu consentimento.

A utilização das entrevistas é relevante por provocar ricas contribuições dos sujeitos conforme afirma Pádua (1997, p.64-65):

a entrevista é um procedimento mais usual no trabalho de campo. Por meio dela, o pesquisador busca obter informes contidos na fala dos atores. Ela não significa uma conversa despretensiosa e neutra, uma vez que se insere como meio de coleta dos fatos relatados pelos atores, enquanto sujeito-objetos da pesquisa que vivenciam uma determinada realidade que está sendo focalizada.

As entrevistas expressam, segundo Chizzotti (1995, p.90), "as representações subjetivas dos participantes", possibilitando intervenções do pesquisador em sua realidade ou ações transformadoras mediante questões problemáticas. 
Foram realizados vários contatos telefônicos com os sujeitos para o agendamento das entrevistas. Todos optaram por realizá-las no local de trabalho, como primeira atividade da manhã (no trabalho) em função da falta de tempo em outro horário. A partir da proximidade e do conhecimento da pesquisadora com os sujeitos, foi possível estabelecer um relacionamento espontâneo, comprometedor e verdadeiro durante o processo da entrevista, tornando possível o aprofundamento das informações obtidas.

A realização das entrevistas contou com a aplicação de um formulário semiestruturado, com perguntas abertas e abrangentes. Teve a finalidade de obter o máximo de informações ligadas ao objeto de estudo. Para Barros \& Lehfeld (2000, p.90), “o formulário é um instrumento mais usado para o levantamento de informações. Não está restrito a uma determinada quantidade de questões [...] e pode possuir perguntas fechadas e abertas e ainda a combinação dos dois tipos".

Para as entrevistas com os sujeitos da pesquisa (educadoras e assistente social), as perguntas abordaram tópicos que nortearam o eixo principal das entrevistas, como: perfil dos sujeitos (nome, idade, escolaridade, tempo de atuação no cargo atual e tempo de atuação profissional), a educação hoje, o trabalho em equipe interdisciplinar, o trabalho do assistente social e as possibilidades de uma intervenção propositiva do Serviço Social na política educacional brasileira (Tabela 3).

Assim, durante o processo de investigação, foi possível utilizar, além das entrevistas, a técnica de observação como importante meio de coleta de dados realizada de forma simples e direta, possibilitando complementar as informações, uma vez que alguns aspectos da realidade apresentada ficam evidenciados nas atitudes dos sujeitos no momento da entrevista. Confirmam Barros \& Lehfeld (2000, p.53) quando apresentam

A observação como uma das técnicas de coleta de dados imprescindível em toda pesquisa científica. Observar significa aplicar atentamente o sentido a um objeto para dele adquirir um conhecimento 
claro e preciso. Da observação do cotidiano formulam-se problemas que merecem estudo. A observação constitui-se, portanto, a base das investigações científicas.

Na pesquisa de campo, as técnicas e métodos de coleta de dados exigem atenção especial do pesquisador enquanto observador e também anotações de campo, com o diário de campo (Triviños, 1987, p.154) que foi utilizado pela pesquisadora, pois por meio do telefone obteve informações dos sujeitos, do universo pesquisado e do trabalho desenvolvido pelos sujeitos.

\section{Caracterização dos sujeitos da pesquisa}

A tabela abaixo define o perfil dos sujeitos da pesquisa.

Tabela 3 - Perfil dos sujeitos investigados/2008

\begin{tabular}{|c|c|c|c|c|c|}
\hline Identificação & Idade & Escolaridade & $\begin{array}{c}\text { Pós- } \\
\text { Graduação }\end{array}$ & $\begin{array}{l}\text { Cargo/ } \\
\text { Tempo }\end{array}$ & $\begin{array}{c}\text { Tempo de } \\
\text { atuação } \\
\text { profissional }\end{array}$ \\
\hline Violeta & 53 & $\begin{array}{c}\text { Superior } \\
\text { Completo/ } \\
\text { Assistente } \\
\text { Social }\end{array}$ & Não possui & \begin{tabular}{|} 
Assistente \\
Social/ \\
5 anos
\end{tabular} & 12 anos \\
\hline Rosa & 41 & $\begin{array}{c}\text { Superior } \\
\text { Completo/ } \\
\text { Pedagogia }\end{array}$ & Psicopedagogia & $\begin{array}{c}\text { Secretária } \\
\text { Municipal } \\
\text { da } \\
\text { Educação/ } \\
4 \text { meses }\end{array}$ & 20 anos \\
\hline Orquídea & 62 & $\begin{array}{c}\text { Superior } \\
\text { Completo/ } \\
\text { Pedagogia }\end{array}$ & Psicopedagogia & \begin{tabular}{|} 
Supervisora \\
Geral da \\
Educação \\
Infantil/ \\
4 anos
\end{tabular} & 40 anos \\
\hline
\end{tabular}

Fonte: Investigação de campo realizada pela pesquisadora/2008 
Os sujeitos da pesquisa foram identificados por nomes fictícios de flores: Violeta, Rosa e Orquídea. Os relatos registrados nas análises serão sempre acompanhados pela identificação do sujeito. Todos os sujeitos da pesquisa são $100 \%$ do sexo feminino e percebe-se que a grande maioria dos profissionais na educação são mulheres que vêm se destacando com grande representatividade no cenário educacional, ilustrado pela Figura 1:

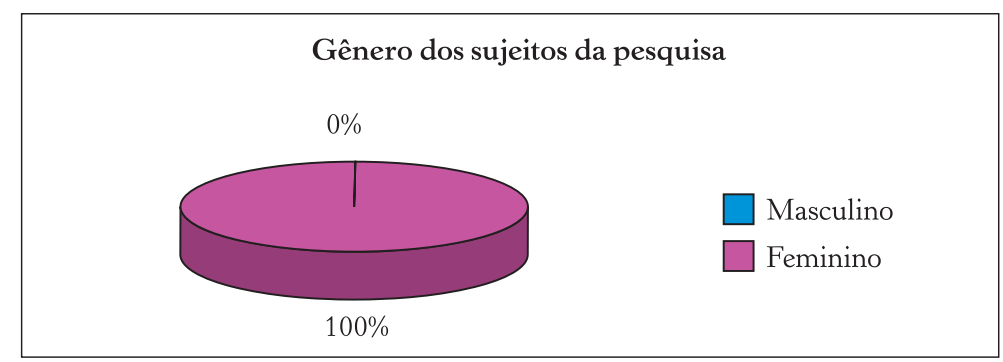

Figura 1: Gênero dos sujeitos da pesquisa

A Figura 2 demonstra que os sujeitos estão na faixa etária entre 40 a 62 anos de idade. Observa-se que a idade é proporcional ao tempo de experiência (67\%), com exceção da Violeta que começou a exercer sua profissão depois de dez anos de graduação em ensino superior, mas acumula uma experiência profissional por ter trabalhado em vários campos de atuação do Serviço Social. Assim demonstra a figura abaixo:

\section{Faixa etária dos sujeitos da pesquisa}

Orquídea; 62

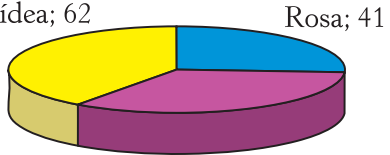

$\square$ Rosa

$\square$ Violeta

$\square$ Orquídea

Violeta; 53

Figura 2: Faixa etária dos sujeitos 
É notável que essa relação idade e tempo de atuação no trabalho educacional revelam o acúmulo de experiência, conhecimento, dedicação, compromisso, realização pessoal e profissional dos sujeitos da pesquisa.

O que revela o relato abaixo:

galguei todos os postos dentro da educação. Tenho longo percurso na educação. Comecei como professora rural, depois fui para São Paulo. Com mudanças no Estado em 1967, não havia a educação infantil no interior de São Paulo. Tive que fazer um exame de seleção para a educação infantil. Após meu curso em São Paulo comecei a trabalhar no Estado como professora em educação infantil. Depois fui coordenadora do ciclo básico, vice-diretora de uma escola Estadual de Barretos. Fiquei dois anos na direção quando o diretor foi secretário de educação e em 1999 fiz o concurso público da prefeitura de Barretos. Aposentei do Estado e na prefeitura sou coordenadora pedagógica e atualmente nesta administração fui convidada para designação de supervisora geral da educação infantil [...] educação para mim é tudo. (Orquídea)

Todos os sujeitos da pesquisa possuem formação em curso superior completo em diferentes áreas do conhecimento, entretanto somente $67 \%$ possuem pós-graduação em nível de especialização, (lato sensu), seguida de 33\% que não realizaram curso algum de pósgraduação. Está visualizada na Figura 3.

Formação acadêmica dos sujeitos da pesquisa

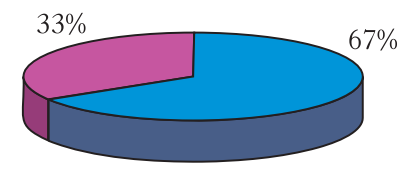

Pós-Gradução

$\square$ Graduação

Figura 3: Formação profissional dos sujeitos 
E ainda revelam a importância da formação continuada para todos profissionais da educação, segundo o relato:

minha formação e atuação sempre foram na área pedagógica. Tenho trabalhado muito na parte pedagógica e acompanhado a formação de nossos profissionais, acompanhado de perto a formação da equipe de suporte pedagógico. Eu acho que qualquer profissional hoje da educação, é da área de gestão e necessita se preparar constantemente. (Rosa)

A educação, nos últimos anos, avançou no âmbito da formação dos profissionais, possibilitando aprimoramento, nova visão no ensino e aprendizagem. Com isso, as reflexões estendem-se para uma escola cidadã, melhoria para qualidade de ensino, para práticas pedagógicas democráticas, para o respeito às diferenças e o protagonismo da criança, do adolescente e do jovem em seu processo de desenvolvimento educacional.

\section{Análise e interpretação dos dados}

A partir da coleta de dados, buscou-se analisar e interpretar as informações. O procedimento metodológico utilizado na interpretação dos depoimentos baseou-se na análise de conteúdo, que, segundo Bardin (1977, p.42), é:

Um conjunto de técnicas de análise das comunicações visando obter, por procedimentos, sistemáticos e objetivos de descrição do conteúdo das mensagens, indicadores (quantitativos ou não) que permitam a inferência de conhecimentos relativos às condições de produção/recepção (variáveis inferidas) destas mensagens.

Essa técnica teve origem nos Estados Unidos no início do século XX. Seus primeiros experimentos estavam voltados para a 
comunicação de massa. "Até os anos 1950 predominava o aspecto quantitativo da técnica que se traduzia, em geral, pela contagem da frequência da aparição de características nos conteúdos das mensagens veiculadas" (Gomes, 2001, p.74). Atualmente, é compreendida como um conjunto de instrumentos metodológicos, e assegura a objetividade, a sistematização e a influência aplicadas aos diversos discursos. E assim "estudar e analisar o material qualitativo, buscando-se melhor compreensão de uma comunicação ou discurso, de aprofundar suas características gramaticais às ideológicas e outras, além de extrair aspectos mais relevantes" (Barros \& Lehfeld, 2000, p.70).

Segundo as autoras (2000, p.71), tal análise tem como suporte instrumental qualquer tipo de mensagem e formas de expressão dos sujeitos sociais, resultando em um conhecimento não linear.

Assim, essa metodologia de análise e de interpretação permitiu compreender criticamente o sentido das falas dos sujeitos, o conteúdo, o manifesto latente, os significados explícitos ou ocultos.

Como afirma Chizzotti (1995, p.99),

Esta técnica procura reduzir o volume amplo de informações contidas em uma comunicação a algumas características particulares ou categorias conceituais que permitam passar dos elementos descritivos à interpretação ou investigar a compreensão dos atores sociais no contexto cultural em que produzem a informação ou, enfim, verificando a influência desse contexto no estilo, na forma e no conteúdo da comunicação.

Mediante tal procedimento de análise, os depoimentos dos sujeitos foram classificados em categorias visando a uma análise fidedigna ao texto (Tabelas 4, 5, 6 e 7).

As categorias estabelecidas antes do trabalho de campo, na fase exploratória da pesquisa exigiram uma fundamentação teórica sólida por meio dos capítulos 1 a 4 desse estudo. São elas: Serviço Social, Educação, Interdisciplinaridade e Perfil Profissional. 
Segundo Barros \& Lehfeld (2000, p.63-4), para que essas categorias na análise dos dados sejam úteis devem atender regras básicas, assim definidas:

a) O conjunto de categorias deve ser derivado em um único princípio de classificação;

b) O conjunto de categorias deve abranger toda e qualquer resposta obtida. Deve ser exaustivo;

c) As categorias devem ser mutuamente exclusivas, isto é, não deve ser possível colocar determinada resposta em mais de uma categoria de conjunto.

Em seguida, as respostas fornecidas pelos sujeitos, receberam um tratamento adequado, tornou-se necessário organizá-las em agrupamentos denominados subcategorias. A partir delas, foi agregado um tratamento percentual, conforme se verifica nas tabelas a seguir.

Tabela 4 - Categoria e subcategorias das entrevistas com os sujeitos da pesquisa: Serviço Social

\begin{tabular}{|c|c|c|c|}
\hline Categoria & Subcategoria & Freq. & $\%$ \\
\hline \multirow[t]{9}{*}{ Serviço Social } & $\begin{array}{l}\text { - Trabalho restrito e desconhecido na } \\
\text { Educação pelos profissionais da educação }\end{array}$ & 1 & 33 \\
\hline & $\begin{array}{l}\text { - Competência e qualidade no trabalho } \\
\text { desenvolvido }\end{array}$ & 3 & 100 \\
\hline & - Importante nas equipes de profissionais & 3 & 100 \\
\hline & $\begin{array}{l}\text { - Ações paliativas, assistencialista e } \\
\text { imediatista }\end{array}$ & 3 & 100 \\
\hline & - Mediador de conflitos emergenciais & 3 & 100 \\
\hline & - Chamada a opinar e sugerir & 2 & 67 \\
\hline & $\begin{array}{l}\text { - Atuação do Serviço Social na Política } \\
\text { Educacional de Barretos } \\
\end{array}$ & 2 & 67 \\
\hline & $\begin{array}{l}\text { - Necessidade do Assistente Social em } \\
\text { todas as áreas da educação }\end{array}$ & 1 & 33 \\
\hline & $\begin{array}{l}\text { - Atendimento aos casos críticos e um } \\
\text { trabalho curativo }\end{array}$ & 3 & 100 \\
\hline
\end{tabular}

Fonte: Dados da Pesquisa. Entrevistas com os profissionais da Secretaria Municipal de Educação de Barretos/SP (2008) 
Tabela 5 - Categoria e subcategorias das entrevistas com os sujeitos da pesquisa: Educação

\begin{tabular}{c|l|c|c}
\hline \multicolumn{1}{c|}{ Categoria } & \multicolumn{1}{|c|}{ Subcategoria } & Freq. & $\%$ \\
\hline Educação & $\begin{array}{l}\text { - Educação é tudo, do nascimento ao fim } \\
\text { da vida }\end{array}$ & 1 & 33 \\
\cline { 2 - 4 } & $\begin{array}{l}\text { - Educação é uma ação simultânea entre as } \\
\text { pessoas }\end{array}$ & 2 & 67 \\
\cline { 2 - 4 } & $\begin{array}{l}\text { - Escola deve ser dinâmica, contemporânea } \\
\text { e transmissora de valores }\end{array}$ & 3 & 100 \\
\cline { 2 - 4 } & $\begin{array}{l}\text { - Escola tem a função de desvendar um } \\
\text { mundo diferente para pessoas diferentes }\end{array}$ & 2 & 67 \\
\cline { 2 - 4 } & $\begin{array}{l}\text { - A família é fundamental no espaço escolar. } \\
\text { - Sentido amplo: intelectual, emocional, } \\
\text { ético e estético }\end{array}$ & 1 & 33 \\
\hline
\end{tabular}

Fonte: Dados da Pesquisa. Entrevistas com os profissionais da Secretaria Municipal de Educação de Barretos/SP (2008)

Tabela 6 - Categoria e subcategorias das entrevistas com os sujeitos da pesquisa: Interdisciplinaridade

\begin{tabular}{c|l|c|c}
\hline \multicolumn{1}{c|}{ Categoria } & \multicolumn{1}{|c|}{ Subcategoria } & Freq. & $\%$ \\
\hline Interdisciplinaridade & - Trabalho valorativo & 3 & 100 \\
\cline { 2 - 4 } & $\begin{array}{l}\text { - Importante e necessário para a educação } \\
\text { hoje }\end{array}$ & 3 & 100 \\
\cline { 2 - 4 } & $\begin{array}{l}\text { - Atuação da equipe interdisciplinar dentro } \\
\text { das unidades de ensino }\end{array}$ & 3 & 100 \\
\cline { 2 - 4 } & $\begin{array}{l}\text { - Existe interdisciplinaridade quando } \\
\text { favorece o trabalho educacional } \\
\text { - É importante a formação de uma equipe } \\
\text { interdisciplinar nas escolas }\end{array}$ & 3 & 100 \\
\hline
\end{tabular}

Fonte: Dados da Pesquisa. Entrevistas com os profissionais da Secretaria Municipal de Educação de Barretos/SP (2008)

Tabela 7 - Categoria e subcategorias das entrevistas com os sujeitos da pesquisa: Perfil Profissional

\begin{tabular}{c|c|c|c}
\hline \multicolumn{1}{c|}{ Categoria } & \multicolumn{1}{|c|}{ Subcategoria } & Freq. & $\%$ \\
\hline Perfil Profissional & $\begin{array}{c}\text { - Profissional cuidadoso, comprometido, } \\
\text { competente e habilidoso }\end{array}$ & 2 & 67 \\
\cline { 2 - 5 } & $\bullet$ Profissional crítico e reflexivo & 2 & 67 \\
\cline { 2 - 5 } & $\bullet$ Experiência no trabalho e dedicação & 2 & 67 \\
\hline
\end{tabular}


Tabela 7 - Continuação

\begin{tabular}{|c|c|c|c|}
\hline Categoria & Subcategoria & Freq. & $\%$ \\
\hline \multirow[t]{8}{*}{ Perfil Profissional } & $\begin{array}{l}\text { - Possui uma nova visão da realidade } \\
\text { social, diferente de muitos profissionais } \\
\text { da educação }\end{array}$ & 3 & 100 \\
\hline & - É um profissional valorizado & 2 & 67 \\
\hline & $\begin{array}{l}\text { - Profissional que deve trabalhar } \\
\text { diretamente com a população }\end{array}$ & 3 & 100 \\
\hline & - Trabalha conflitos e o emergencial & 3 & 100 \\
\hline & $\begin{array}{l}\text { - Profissional calmo e que ajuda as } \\
\text { pessoas }\end{array}$ & 2 & 67 \\
\hline & - Atuação eficaz e responsável & 3 & 100 \\
\hline & - Assistencialista e imediatista & 3 & 100 \\
\hline & - Orienta, informa e motiva & 3 & 100 \\
\hline
\end{tabular}

Fonte: Dados da Pesquisa. Entrevistas com os profissionais da Secretaria Municipal de Educação de Barretos/SP (2008)

Com base em tais categorias e subcategorias, procedeu-se à triangulação dos dados referentes à pesquisa de campo, à bibliográfica e documental que são apresentadas no próximo item.

\section{Resultados e discussões}

São apresentados, nesse item, os resultados da pesquisa de campo realizada com os profissionais da Secretaria Municipal de Educação de Barretos (sujeitos da pesquisa): Assistente Social, Supervisora Geral de Educação Infantil e Secretária Municipal de Educação, como também dos profissionais da Secretaria Municipal de Educação do Município de Osasco objetivando a apresentação do trabalho desenvolvido pelo Serviço Social junto à educação como proposta de intervenção ao universo estudado.

As Tabelas 4, 5, 6, 7 para a análise de conteúdo com categorias e subcategorias, permitiram discutir e analisar o trabalho profissional do assistente social na educação municipal de Barretos e propor um perfil profissional no cenário educacional. 
A análise das entrevistas revela que todos os sujeitos conhecem o trabalho do Serviço Social e acreditam em sua importante ampliação na Secretaria Municipal de Barretos, bem como o aprimoramento e a qualidade no trabalho desenvolvido. As falas a seguir confirmam tais afirmações:

O trabalho do Serviço Social poderia ser mais incrementado, aliás até luto por isso[...]. Eu vejo muito positivo o trabalho da Assistente Social porque sem essa ajuda, alguns casos seriam impossível de ter resolução. Acho que o profissional do Serviço Social tende a valorizar o trabalho de uma maneira geral. E em todas as esferas do Brasil é necessário essa posição, esse funcionário. E nosso país conforme ele vai se atualizando, ele vai tendo contato com outros países, ele vai vendo a necessidade do profissional de Serviço Social dentro de todos os ângulos. (Orquídea)

hoje temos a parceria, mas gostaríamos de estender essa parceria e realmente ter funcionários do Serviço Social atuando dentro da educação. A gente vê que pelo tempo da assistente social não conseguiria fazer mais, mas o tanto que ela faz, a gente vê a importância. Ela atua em muitos casos, próximos às famílias, mas como nós temos hoje mais de 12 mil alunos na rede, um profissional só é humanamente impossível. (Rosa)

Vejo para Barretos, independente da administração que teremos em 2009, a esperança que realmente o Serviço Social se consolide na Secretaria da Educação. Acredito que realmente isso vai acontecer, independente de qual administrador nós tivermos, porque tanto um quanto o outro pensam no Serviço Social como profissional que pode estar colaborando e muito. (Violeta)

Para os profissionais de Osasco a mesma realidade se confirma, pois todos os entrevistados conhecem o trabalho dos assistentes sociais. O trabalho está organizado por meio de uma equipe interdisciplinar formada por assistentes sociais, psicólogos e fonoaudiólogos. 
Conta com 22 assistentes sociais nas escolas de educação básica, uma assistente social nas duas escolas de educação especial com portadores de deficiência auditiva e outras necessidades especiais e uma assistente social no Centro Diagnóstico. Contudo, estudam a possibilidade de aumentar o número de assistentes sociais em decorrência das demandas sociais. Assim, segundo Hortência, o trabalho das assistentes sociais tem revelado um avanço nos trabalhos junto à população:

Sempre existiu a visão de que a assistente social é importante na estrutura da Secretaria da Educação, embora o trabalho específico do Assistente Social, na gestão anterior, não tinha sido sistematizado. Então nesta gestão de 2005, estão tendo um olhar de maior importância sobre a equipe técnica. Existia uma equipe técnica trabalhando com as Cemeis - Centros Municipais Educação Infantil, de 0 a 6 anos. Tem Assistentes Sociais nas creches, elas dividem-se por setores e trabalham com uma psicóloga e uma fonoaudióloga. Hoje, encontra-se mais sistematizado o trabalho desta equipe interdisciplinar. A nova gestão começou avaliar o trabalho da equipe técnica, porque na secretaria temos o Cedipo - Centro de Diagnóstico, para crianças com necessidades especiais. Essas profissionais trabalhavam somente com a formação dos profissionais, não trabalhavam diretamente com as famílias e crianças. Hoje ampliamos essa atuação. (Margarida)

Observa-se, diante disso, que o profissional de Serviço Social por meio de uma intervenção educativa, competente e propositiva, no enfrentamento das demandas sociais, tem revelado um perfil profissional diferenciado, fundamental na educação e valorizado pelos gestores educacionais.

Não obstante a essa realidade de reconhecimento da profissão diante dos dirigentes das secretarias, percebe-se que existe uma resistência aos profissionais de Serviço Social por parte dos educadores que compõem o quadro de funcionários da Secretaria da Educação de Barretos, diretores, professores e demais profissionais das unidades 
de ensino, visto que se observa um grande desconhecimento da profissão e uma visão distorcida, ou seja, refutam a proposta de atuação do assistente social, como profissional qualificado e competente para trabalhar as questões sociais que interferem na política educacional e refletidas nas escolas, mesmo diante do despreparo desses educadores em trabalhar com esses conflitos que se manifestam no processo ensino e aprendizagem do aluno.

Teve muita resistência do Serviço Social na educação, principalmente quando colocou o estagiário de Serviço Social, dentro do Cemei, acharam como interferência, eles acharam tudo muito bonito, o Assistente Social dentro do Cemei, quando foi para resolver aquilo que eles queriam. Então, se é um problema que eles sentiram e não conseguiram resolver e acreditaram que o Serviço Social pode resolver, então o Serviço Social é muito bem-vindo dentro do Cemei e na escola[...]. A maioria dos diretores de escola de ensino fundamental, eles realmente não aceitam o profissional de Serviço Social, eles entendem que o profissional vai interferir e eles já tem diretores, eles tem supervisores, professores, coordenadores e não há necessidade de mais um profissional que vai estar passando a mãozinha na cabeça do aluno, na família desses alunos, eles podem estar desenvolvendo e eles mesmo vão fazer a visita. Eles tem ainda a ideia que o profissional de Serviço Social é aquele bonzinho, que vai ficar contra a escola, a favor da mãe, mesmo que ela esteja errada, e não é mesmo assim, eles não entendem como sendo profissional que vai verificar a questão social daquela família e tentar mexer na base, no que está provocando e eles acham que só o pedagógico é o suficiente e a escola está só para o pedagógico e o social é outro setor, outro lugar. (Violeta)

O professor não é assistente social, não é psicólogo e não é fonoaudiólogo. O que acontece é que o professor pode perceber um problema no aluno que possivelmente seja um dado problema que não pode afirmar porque não é técnico nisso, percebe um comportamento atípico e precisa de apoio. Então quando falta este apoio 
ao professor na sala de aula e não tem, seu trabalho é desestimulado e quando sabe que terá um respaldo, alguém vai até mesmo para conversar, ele se sente leve para o trabalho, falo enquanto professora há vinte anos. (Hortência)

As falas acima demonstram dois aspectos fundamentais em discussão no Serviço Social: o desconhecimento dessa profissão social por meio de sua trajetória histórica e propositiva nos diversos campos atuais de intervenção no sistema capitalista e a concepção conservadora de uma profissão assistencialista e executora de práticas caritativas e filantrópicas.

Dessa forma, o Serviço Social ainda é visto na concepção dos sujeitos entrevistados como um trabalho assistencialista, paliativo, curativo e emergencial. Isso significa que o profissional não conquistou por meio de seu trabalho profissional técnico-operativo e ético-político uma intervenção propositiva, transformadora, criativa e qualificada, como características efetivas da profissão.

É um trabalho assim, de formiguinha e que tem dado muito certo no atendimento às famílias dos nossos Centros de Educação Infantil[...] Eu sei que é um trabalho difícil de ser atendido, não é um trabalho de prevenção, é um trabalho de cuidar de alguns casos. Casos mais prementes, casos que se tornam impossíveis de serem atendidos pela diretora, pelo pessoal que está envolvido com a criança, devido ao estudo, a disponibilidade de atendimento, ela procura ir ao encontro apenas naqueles casos que necessitam de uma compreensão maior, de uma maneira diferenciada de atendimento, então está aquém dentro dos Centros Municipais de Educação Infantil. (Orquídea)

Quando você tem um número muito reduzido de profissionais você acaba atendendo só aqueles casos críticos e num trabalho curativo [...]. Aqui em Barretos eu avalio assim pela única assistente social que nós temos, é excelente, mas eu avalio que está muito carente, porque nós temos uma profissional só. (Rosa) 
Onde houver uma questão que a diretora e o professor, educador ou professor não conseguiu resolver, a assistente social é chamada para tentar intermediar esse conflito que existiu, ou resolver a questão que foi aparecendo[...]. Dentro das escolas de Ensino Fundamental, de $1^{\circ}$ ao $9^{\circ}$ ano, ainda não desenvolvi nenhum trabalho, a não ser coisas esporádicas que me chamaram para intermediar uma conversa diretora, vice-diretora, professora e a família, que seria apagar o fogo, apagar o incêndio no momento, mas, fora isso, não foi desenvolvido nenhum trabalho. (Violeta)

Não obstante a essa realidade, é consenso entre os profissionais de Osasco a importância do Serviço Social na Secretaria da Educação, assim como a valorização externa dos demais profissionais e do próprio profissional social. Isso fica evidente nas expressões abaixo:

Avalio que o trabalho da Assistente Social é de extrema necessidade, ela tem uma visão diferenciada, faz uma abordagem diferente do problema, fora a questão do atendimento que faz do aluno, acho importante não a forma de tratar o problema, mas a prevenção de como podem orientar os nossos profissionais, diretores, professores, funcionários envolvidos com a criança. Por exemplo, a legislação que ampara a criança, as atitudes que tem que tomar nas situações, a forma de diálogo e conversa com os pais, até na questão do preparo; nós somos profissionais de outra área, acho que é um conhecimento que soma na equipe, acho imprescindível. (Hortência)

No trabalho de orientação à família, visando a um processo educacional tranquilo e harmonioso da criança e no acompanhamento das equipes de profissionais nos centros de educação infantil, o assistente social tem se revelado como um profissional de suma importância para o acompanhamento e o trabalho direto junto às diversas formas de organização de família que se redesenham no cenário nacional.

é importante a presença do assistente social para tranquilizar, dizer que é importante que essa criança esteja no núcleo familiar, dispor 
à população o conhecimento que é próprio do profissional Assistente Social. É importante a atuação nesta informação dos direitos à população. Podemos em alguns casos visualizar a qualidade nos resultados, mas agora com a intensificação dos trabalhos teremos mais consistências nos resultados. As equipes de creche, as profissionais são mais próximas dos trabalhos vividos diariamente, não são arrogantes em relação ao trabalho intelectual e de atendimento à população, portanto, avalio que estão muito mais comprometidas com o interesse da população escolar. Elas são mais próximas dentro da realidade, tem contato com os problemas diários da creche, queé um trabalho antigo, tanto é que a equipe continua a mesma da gestão anterior. A gente pensa muito em fazer alteração dessa equipe, porque está muito sintonizada com o trabalho, com os dirigentes, conhece as mães e a realidade das crianças. A equipe das Cemeis tem contato com os professores e dirigentes, existe um planejamento de Cemei que será intensificado com o novo projeto de combate à exclusão social, dessa nova administração. (Margarida)

O acompanhamento da equipe dos profissionais da educação é muito importante, inicialmente, pelo levantamento dos problemas sociais que afetam a educação hoje e o enfrentamento destes com toda a comunidade escolar, família e sociedade em geral.

Não temos um trabalho específico de assistência social, temos um setor de assessoria interdisciplinar na qual a assistente social está incluída, que assessora as unidades escolares, seus gestores, ou seus professores, funcionários de apoio, na busca de soluções para situações relativamente localizadas, de crianças nas quais se detecta deficiências ou dificuldades, que é diferente, ou dificuldades de aprendizado e também naquelas que conseguimos detectar uma situação mais de violência familiar, violência social, perigo, risco social, até mesmo violência sexual, em que deve haver um grupo intersecretaria que acompanhe essas crianças. Mas nós, como disse, temos a tarefa na unidade escolar, produzir o assessoramento, para que a unidade escolar em sua complexidade busque atender da melhor forma pos- 
sível essas crianças. Feito por um setor de assessoria Institucional Educacional, esses profissionais, esses técnicos que nós chamamos. Considero importante o trabalho interdisciplinar. (Girassol)

A fala do profissional Girassol revela um desconhecimento com relação ao Serviço Social e isso se deve a dois aspectos, segundo ela mesma: ter assumido recentemente (há 2 anos) a Secretaria da Educação de Osasco e nunca ter trabalhado com profissionais assistentes sociais.

Estou há pouco tempo na secretaria e eu ainda não me sinto em condições de precisar o trabalho que é desenvolvido. Realmente não tenho essas informações. É no sentido de eu ignorar mais detalhes dessa atividade [...] Quando as creches vão para a educação e perdem a característica assistencialista, as assistentes sociais perdem espaços para os pedagogos, aliás nesta equipe tem pedagogos também. Elas perdem o espaço para os pedagogos, deixam de ser o atendimento cuidar e passam a ser o cuidar educar, então perdeu esse espaço, não perdeu, compartilhou o espaço, eu acho. Então, os profissionais ficaram meio soltos, sem terem muita função, sem terem potencializado as possibilidades de colaboração, e aí foi criado o núcleo de atendimento especializado. É um espaço organizado. Vieram para dentro da Secretaria de Educação junto com a equipe pedagógica da educação, porque eles tinham um espaço separado. Como se fosse mesmo um recurso que a educação solicitava. Agora não, eles são a educação. Então é uma equipe que trabalha em harmonia com a diretoria de ensino da secretaria. Um exemplo, nós agora tivemos uma seleção de pajens, nós vamos reenquadrá-las, e antes que fossem para as suas unidades de trabalho, esta equipe do Saei fez uma capacitação com elas, uma pequena formação. Cada uma das profissionais, das técnicas, pode dizer seu lado do prisma no que compete às pajens. (Girassol)

Trata-se de uma visão equivocada do Serviço Social, pois não houve perda de espaço, mas redimensionamento das competências profissionais, desconhecidas até então pela profissional acima citada. 
Nesse sentido, tal realidade reforça-se com o depoimento do sujeito da pesquisa, a Violeta, que apresenta os limites de seu trabalho profissional como burocrático, restrito e mediador (minimizador) de conflitos de relacionamentos, pessoais e emergenciais, demonstrando, muitas vezes, o desvio de competências profissionais, como afirma:

O meu trabalho é basicamente com a educação infantil no agendamento de crianças que precisam estar indo para vagas em creche, então eu faço toda uma lista de espera, o atendimento da mãe ou do pai, aqui na secretaria, faço o agendamento, entra numa lista de espera para ser chamado posteriormente, caso não tenha vaga no momento [...] Em muitos casos, que devo ir no local, é o descumprimento de regras e normas estabelecidos dentro dos Cemeis. Então, as famílias não levam no horário, ou não pegam no horário, ou a criança está com piolho, não querem atender, ou querem que deem medicamento dentro do Cemei, o que não é permitido, faltas sem justificativa, que a gente tem que verificar e desentendimento verbal com a diretora. Por alguns destes problemas que a mãe não aceita e a diretora não tem o jogo de cintura ou habilidades necessárias, vamos colocar assim, para estar conversando, explicando a necessidade de cumprir aquelas regras. Então, elas acabam medindo forças, a hora que uma quer ser mais poderosa que a outra, elas não chegam no acordo, é quando o profissional de Serviço Social é chamado, justamente para entrar neste meio e quebrar esta força e tentar balancear tudo isso e fazer cumprir a lei, mas vendo o que é correto para os dois lados, o que um tem de direito e o que tem de dever também e o que o outro tem que ser maleável e aceitar e entender a situação. Todos os casos foram resolvidos. Um ou dois casos não foram resolvidos num primeiro momento, mas na segunda conversa também já foram resolvidos. Não ficou nenhum pendente. Agora, a gente tem uns casos que eu sou chamada, de violência doméstica, desse caso, eu vou faço a visita, vejo o que está acontecendo realmente e chamo o Conselho Tutelar. (Violeta)

Essa realidade diferencia-se do município de Osasco, onde os profissionais apresentam a relevância do trabalho desenvolvido e 
o reconhecimento do mesmo pelos profissionais que atuam direta e indiretamente com os assistentes sociais e são beneficiados pelo trabalho da equipe interdisciplinar. É destaque a forma como ocorreu no preparo e na aceitabilidade da equipe na Secretaria da Educação, como se evidencia nas falas abaixo:

Foram feitas várias reuniões antes da circular, reunião de direção, em cursos para a equipe, foi preparado para receber a equipe interdisciplinar. Mas também foi uma solicitação dos próprios professores, eles têm o seu trabalho, e a escola vai adquirindo o exercício do paternalismo excessivo e o profissional acaba assumindo responsabilidades que não são deles, a sua função é alfabetizar, trabalhar as questões pedagógicas[...] Acredito que somos privilegiados não só porque temos a equipe interdisciplinar, mas porque temos profissionais extremamente competentes, as assistentes sociais são envolvidas, acredito que seja uma característica própria do profissional porque lida com o social, esse compromisso que elas têm, são só mulheres, que é até excessivo com o público e com a clientela que elas atendem têm uma responsabilidade muito grande. (Hortência)

Eu acho que sim, principalmente neste projeto de combate à exclusão social, discutimos a diversidade étnica em respeito à LDB, entendemos que não é só o professor na sala de aula, também o profissional dando atenção a essas questões, respeitando essa diversidade étnica e aqui no município tem uma Coordenadoria de Gênero e de Raça e há momentos de reunião da equipe interdisciplinar com essa coordenadoria. Há uma interface com outras Secretarias. A coordenadora das EMEFS confirma uma excelente aceitação da rede para com a equipe interdisciplinar, após o envio da circular. No setor dela muitos tem procurado como trabalha este núcleo interdisciplinar. Pedimos aos diretores que encaminhem a esse núcleo todos os casos de cada unidade. Avaliamos como muito positivo. (Margarida)

É relevante a formação da equipe interdisciplinar no trabalho da educação, segundo a fala dos sujeitos e profissionais, pois dessa 
forma é possível atender às diversas demandas dos alunos durante seu processo de desenvolvimento e de aprendizagem e, consequentemente, de seus educadores.

Foi muito importante a existência desta equipe, o trabalho desta equipe. Como iniciamos o processo de inclusão, desenvolvemos um programa de educação inclusiva, era razoável que o professor que não teve essa formação nem no seu ensino normal e nem na faculdade, se angustiasse diante de uma criança incluída com deficiências ou necessidades. Eu acho que num primeiro momento nem o professor sabia muito bem tratar com o problema social, seria a questão da violência, de qualquer natureza, então não havia esse recurso. Então, acabamos matando dois coelhos com uma cajadada só. Nós conseguimos sob a perspectiva da interdisciplinaridade como o fisioterapeuta, terapeuta ocupacional, psicólogo, pedagogo e o assistente social dar uma assessoria, dar um suporte, dar uma orientação para o professor, angustiado, que tinha recebido este aluno com PC ou com uma deficiência motora, ou com problema de descontrole dos esfíncteres, e também conseguimos ter esta equipe para acompanhar esses casos que detectados ou pelo Conselho Tutelar e se a escola não tivesse como ajudar. Então, nesta equipe e na equipe a assistente social, eu acho, que foi muito importante, porque antes e como professora posso dizer isso, eu tive uma aluna que foi vítima de estupro, uma jovem admirável, então a escola, soubemos que tinha sido vítima de estupro. Mas, não havia um elo entre aquela família e nós, naquela circunstância. Eu acho que o Saei, isso, pode ser amenizado. É possível estabelecer uma ponte, isto é, incorporar a escola na vida e a vida na escola. Acho importante esta equipe. (Girassol)

Nesse sentido, os sujeitos entrevistados são unânimes em afirmar também que acreditam em um trabalho interdisciplinar (100\%), embora o trabalho atual do Serviço Social junto à coordenação da educação infantil não caracterize interdisciplinaridade, por se tratar de um trabalho desenvolvido por uma assistente social, sem contar com a presença de profissionais de outras áreas e quando ela neces- 
sita consulta a chefia (secretária da educação e supervisora geral) para a tomada de decisões. Entretanto é otimizada a concepção da importância de uma equipe profissional com características interdisciplinares e a busca na formação desta por parte dos dirigentes da Secretaria Municipal de Educação de Barretos.

Eu acho importante a atuação interdisciplinar. Aliás quando eu tento dar uma explicação a você, eu penso no que ela desenvolve. Ela nunca faz um trabalho sozinha, de acordo com as orientações que ela teve no curso que aprendeu, ela sempre faz um trabalho de equipe. Ela me comunica, ou ela conversa com a diretora, ou com a coordenadora que está no cotidiano com essa criança para saber detalhes. Quando tem um caso mais específico, sempre vamos juntas à família, então sempre é um trabalho de equipe, não isolado. (Orquídea)

Mesmo diante de alguns limites apresentados pelos sujeitos pesquisados no trabalho da assistente social na educação, é importante considerar que os sujeitos entrevistados são unânimes (100\%) em afirmar que o trabalho do Serviço Social desenvolvido na Secretaria Municipal de Educação de Barretos e as demais parcerias que ela possui, são desenvolvidos com competência e qualidade, destacandose sua relevância mediante os diversos profissionais das instituições envolvidas no trabalho.

Hoje nós temos parceria com a FEB, do curso de Serviço Social que atua junto conosco e temos tido a felicidade de receber só elogios a esses trabalhos profissionais[...] Nós temos uma outra parceria com uma entidade que tem um projeto conosco e a assistente social desenvolve um trabalho com famílias muito carentes das crianças da educação, o que é muito importante e necessário. (Rosa)

Ainda no tocante à importância da interdisciplinaridade, os profissionais entrevistados afirmam que é fundamental um trabalho em nível interdisciplinar, ou seja, é preciso fomentar o diálogo, as trocas de saberes, a intersubjetividade situando-se total, concreta e 
historicamente, para o êxito de todos os trabalhos, pois depreende-se que não existe sucesso em qualquer trabalho social e/ou educacional sem a conjugação de esforços, conhecimentos, saberes, investimentos e ações diretas junto à população atendida e na implementação de projetos educacionais e sociais propostos.

então a presença das assistentes sociais só enriquecem nosso trabalho. Eu acredito que estão capacitadas para um tipo de trabalho que outros não estão, cada profissional tem sua importância. Assim como eu acredito que por exemplo, em determinadas situações possam ter um pedagogo na área da saúde, se o objetivo é uma criança que tem que entrar na escola e precisa da parte pedagógica e está no hospital, a presença de uma pedagoga pode ser necessária também. Não é questão de invadir a área de ninguém. Mas é somar, dentro da sua área você fazer, elas fazem o que é trabalho de uma Assistente Social dentro de uma Secretaria da Educação. É ver um cidadão como um todo. O mesmo aluno que tem dificuldades de português, matemática, é o mesmo aluno que fica na rua, ajuda catar latinhas, fica sem ir à escola porque a mãe tem vários filhos e ele tem que cuidar do irmão menor. É o mesmo aluno que o pai é alcoólatra, é agressivo e que tem problemas de "fono", problema mental e que é discriminado por questões raciais e sociais. Não dá para dividir a pessoa, aí a atuação da equipe interdisciplinar. Os questionamentos são que as escolas públicas devem ter psicólogos, assistentes sociais, fisioterapeutas, nas empresas, nos serviços privados se tem e por que o público não pode ter? Por exemplo, eu enquanto pedagoga faço uma leitura da realidade da criança, mas somente na minha visão e quando junta outras profissionais, se tem uma visão ampla, e dentro da educação não podemos perder isso. Temos aprendido muito com as "meninas", assistentes sociais. Acho que o que tem muito nelas é organização, o cronograma, organização técnica das coisas, de registro. Aprendi muito com a assistente social nisso. (Hortência)

Outro aspecto relevante observado entre os sujeitos da pesquisa é que a iminência de um trabalho interdisciplinar na Educação de 
Barretos, com a atuação do Serviço Social possibilitará a construção de uma nova visão da profissão, de forma valorativa, superando a fragilidade do trabalho atual que se caracteriza como ações assistencialistas e imediatistas.

Eu particularmente como profissional de Serviço Social acredito muito no trabalho interdisciplinar e acho necessário, mas outros profissionais da área de educação, eles só valorizam essa interdisciplinaridade a partir do momento em que você mostra resultado do seu trabalho; se você foi lá, fez um trabalho e eles viram que eles foram favorecidos com aquilo, eles aceitam, do contrário eles acham que é uma interferência desnecessária[...] Mas, acredito que a partir de 2009 a gente vai ter um Departamento do Serviço Social montado com mais assistentes sociais, mais profissionais, com estagiários, a parte administrativa e uma sala decente para a gente estar conversando sem muitas interferências. Eu vejo, a cabeça da secretária, o pensamento dela hoje com relação ao Serviço Social nos leva a pensar que tudo isso vai estar acontecendo na próxima administração, já existe uma base, um conhecimento do que o profissional pode estar realizando, da sua valorização pelo gestor para que possa ser montado efetivamente esse setor a partir de 2009. (Violeta)

A educação, apresentada como política social primordial ao cidadão hoje, foi destaque na fala dos sujeitos e profissionais dessa investigação, pois demonstraram a urgente necessidade de investimentos, para uma possível educação de qualidade, com valorização e estimulação do potencial de seus sujeitos, por meio da contribuição de outros saberes e conhecimentos, do diálogo com outras ciências, visando rever os paradigmas que a educação sempre se pautou e a serviço de quem esteve historicamente, como afirmam os sujeitos pesquisados $(100 \%)$ :

brigamos por uma educação de qualidade. Então a educação hoje tem as características interdisciplinar e multidisciplinar, que é aquilo que nós acreditamos como proposta pedagógica [...] (Hortência) 
a ideia tanto para o profissional do Serviço Social que a gente está pensando e lutando para colocar esse profissional, como o profissional psicólogo, que a gente pensou numa equipe multidisciplinar dentro das escolas, que seria um profissional de Serviço Social, um psicólogo e uma fono também. Mas essa equipe para estar acompanhando junto com professores também, nessa proposta preventiva de acompanhamento e não curativa. (Rosa)

Para mim educação é desenvolver, fornecer a criança os conhecimentos historicamente acumulados, mas esse processo desenvolve nela a vontade do saber, para além disso vejo a educação como um instrumento, um processo que visa a criança desenvolver a sua potencialidade de civilização, de humanização, de colaboração, mais ou tanto quanto de ensino propriamente dito. A educação é o ensino, mas é o caráter que chamo civilizatório, a adequação da natureza humana ao convívio salutar, humano, cooperativo, civilizatório e de cidadania. (Girassol)

A educação é fundamental a todo cidadão e como direito social adquirido, devem hoje os educadores segundo os sujeitos pesquisados pautar suas ações na garantia de uma prática educativa reflexiva, crítica, dialética, dialógica.

Escola faz parte da maneira de nós educarmos nossas crianças, então ela tem que ser dinâmica, contemporânea, não esquecendo os valores, principalmente os valores daquele momento, os valores que nos são passados pelos nossos pais, pelo saber da humanidade e isso só se dá através da escola. Eu acho essencial que essa escola fique sempre nesse dinamismo procurando sempre uma maneira atual de educar. (Orquídea)

o grande objetivo da escola é preparar esse cidadão considerando esses aspectos não só o intelectual, o afetivo, o ético, estético. Hoje você tem uma escola que prepara pessoas diferentes, para um mundo bastante diferente. (Rosa) 
Para os profissionais entrevistados, a educação escolar hoje se revela como momento diferenciado no cenário nacional, com propostas de novos métodos educacionais e conteúdos para que a criança, o adolescente e o jovem saibam interpretar o mundo. Assim, demonstra a Tabela 5 .

Neste conceito, a escola é o espaço privilegiado para essa tarefa básica da Secretaria da Educação enquanto serviço público, e essa tarefa que a rigor é de todos, da cidadania, mas no sentido do cidadão o ser humano, pressupondo os direitos, mas anteriormente desenvolvendo essa característica do ser humano. Então, é o espaço onde você tem que ter os recursos para o desenvolvimento de inteligências, conhecimento, aprendizado e também o espaço de convivência, de confronto de ideias, adequação de comportamentos. A criança vai aprendendo também na escola, não só, mas lá como espaço privilegiado, ela vai aprender se a sua ideia não for aceita pela maioria, se a sua compreensão não for a mesma da maioria, ela não adianta sair esperneando, brigando e quebrando no comportamento mais adequado. A escola tem essas funções do conhecimento e mais a da convivência. (Girassol)

Outro dado importante observado entre os profissionais que contribuíram no acréscimo da pesquisa é o trabalho que as assistentes sociais desenvolvem na Secretaria Municipal de Educação de Osasco.

Segundo os profissionais, a estrutura da Secretaria da Educação está dividida em quatro núcleos, os seguintes: Núcleo Interdisciplinar, Núcleo de Educação Infantil, Núcleo de Educação Fundamental e Núcleo de Educação Especial.

Temos a Secretária e nós da equipe técnica estamos no Núcleo Interdisciplinar. Um professor é o coordenador do Núcleo e eu respondo pela coordenação direta da equipe interdisciplinar. (Margarida)

Todos eles possuem assistentes sociais atuando em equipes interdisciplinares. O que se observa no município de Osasco é a dinamici- 
dade do trabalho junto à educação básica, os níveis: educação infantil e educação fundamental e um investimento e valorização no desenvolvimento do trabalho nos últimos anos, como diz a profissional:

Quando o Secretário assumiu esta pasta ele tinha um olhar muito ruim, havia sido informado que a equipe técnica não trabalhava. Inicialmente pedimos uma reunião com ele e este documento é fruto da história da inserção do Serviço Social no município de Osasco, ele é fruto dessa nossa preocupação que existem profissionais sérios, comprometidos com o trabalho e hoje com o Prof. V. e da confiança do Secretário, conseguiu conferir isso, a importância dos profissionais, e esta leitura dessa nossa intencionalidade em mostrar seriedade. (Margarida)

Assim, o Serviço Social tem assumido um papel relevante na educação de Osasco, com grande responsabilidade, compromisso, ética e reconhecimento frente à sociedade que é beneficiada com o trabalho profissional.

Estamos avançando e com as assistentes sociais não teremos muita dificuldade para que consigamos responder a esse desafio que está colocado, que é reforçar o Serviço Social na Educação e da equipe interdisciplinar. Não é uma tarefa só do assistente social, mas acho que os assistentes sociais vão continuar saindo na frente, por conta da história que tem, do perfil de formação, do tipo de formação, do trabalho que propõe a fazer que é diferenciado. Acredito que a resistência com esse profissional vai ser menor, ele sair novamente na frente dessa luta, que também é uma briga. Nos exemplos aqui de arquitetos sociais, ocupando secretarias que gerenciam os projetos sociais, e isso é uma preocupação nossa enquanto categoria, ou seja, profissionais que não estão instrumentalizados teoricamente para atuarem nas questões sociais e vão ocupando os espaços. Essa é uma preocupação nossa. E neste aspecto, acho que o assistente social é bem mais sensível, mais tranquilo de se discutir e se comprometer com o trabalho. Então temos essa tarefa institucionalmente que é da 
equipe interdisciplinar, acho que o assistente social sai na frente, ele avança mais nessas questões. (Margarida)

O trabalho da equipe interdisciplinar, segundo os profissionais entrevistados, é desenvolvido junto à comunidade escolar, profissionais da educação, famílias dos alunos, órgãos públicos responsáveis pelo bem-estar da população infanto juvenil, jovens em situação de vulnerabilidade social, como prostituição infantil, trabalho infantil, violência doméstica, miserabilidade social, uso indevido de drogas e a população em geral de forma preventiva e curativa.

Eu tenho atendido vários casos de violência doméstica [...] através do programa bolsa família, temos acesso ao índice alto de evasão escolar[...] Temos o projeto de "Combate à Exclusão", que propõe a educação inclusiva que não envolve somente portadores de necessidades especiais e nem só formação de professores, mas sim os alunos que estão excluídos pela questão da diversidade étnica, em situação de prostituição e trabalho infantil, violência doméstica, drogadição, enfim, as linhas de trabalho que foram definidas naquele projeto[...] (Margarida)

O professor é orientado quando o aluno tem cinco faltas consecutivas, sem comunicação da família, atestado médico, nenhum aviso, então a escola entra em contato com a família. O professor entra em contato com a secretaria da escola e esta comunica o pai, que é notificado e caso não compareça é convocado a comparecer na escola. E se o aluno continua faltando e o pai não comparece, aí eles encaminham para cá e temos essa ciência. E neste caso é a assistente social diretamente ligada porque é um caso social. Neste caso a assistente social, antes de encaminhar ao Conselho ou a Vara da Infância ela tem todo um trabalho para conhecer a situação. Eu falo sempre que os pais tem um respeito com a figura da assistente social, então uma conversa, orientação com a Assistente Social já resolve [...] Só o fato de ser uma assistente social já coloca uma outra postura no pai. (Hortência) 
Segundo a fala desses profissionais, a educação do município de Osasco/SP desenvolve um projeto elaborado pela equipe denominado "Combate à Exclusão". Foram mapeados todos os bairros periféricos do município (os quatro cantos da cidade), diagnosticados os problemas emergenciais (acima citados) e recebem a intervenção da equipe no tratamento dos problemas e ações preventivas junto à comunidade em geral. Têm-se notícias que, em meados do ano de 2008, a equipe interdisciplinar fez um trabalho de ações intensas junto às famílias no combate à violência doméstica contra as crianças e os adolescentes.

No que diz respeito à proposta de um trabalho profissional que extrapole a intervenção tradicional no espaço escolar e junto à população usuária, 67\% dos sujeitos pesquisados afirmam ser fundamental a atuação do Serviço Social na elaboração de uma política educacional, a fim de contribuir para uma educação de qualidade, inclusiva e participativa.

Quando eu falei da equipe dos profissionais, eu já penso numa certa relação com a construção e elaboração dessa política, na inserção, porque para o gestor; quando eu falo do profissional dentro da escola, é para ela estar trabalhando com os professores, com o diretor da escola, com o gestor, eu acho que como nós estamos hoje fazendo o Plano de Ação Articulada - PAR, é onde você constrói essa política educacional, aí eu vejo que esse profissional estaria ajudando a construir o projeto político pedagógico da escola, da Secretaria Municipal de Educação, que hoje o próprio plano da educação é construído pelos gestores, e esse profissional estaria junto, estaria atendendo com os gestores da escola, com o coordenador pedagógico e eventuais casos, ou casos necessários da escola também, mas eu acho que é imprescindível sim, ele atuar dentro da elaboração da política educacional do município e das escolas. (Rosa)

Nós temos visto isso tanto na esfera do País, na esfera estadual, na esfera municipal, porque nós temos na promoção social algumas profissionais, na educação infantil infelizmente uma só. Mas cada vez 
mais é necessário isso, esse tipo de atuação do profissional, porque o profissional tem uma nova visão que às vezes para a professora, ou na área pedagógica, que nós estamos inseridos no aprender, isso às vezes passa despercebido. Então, com essa ajuda, com essa nova visão, esse trabalho conjunto tende a crescer. (Orquídea)

Com relação aos profissionais pesquisados, observam-se limites de propostas em conceber a atuação do profissional de Serviço Social na proposição e na elaboração de políticas sociais, em especial a educação, a não ser na execução e na implementação de ações já elaboradas. É possível que tal realidade ocorra por modelos históricos da profissão em responder à questão social gerada pelo sistema capitalista de forma paliativa, minimizadora de conflitos sociais e assistencialista. Na visão otimista da profissional Margarida, o Serviço Social tem se destacado no cenário nacional e, possivelmente, irá encontrar brevemente caminhos de propostas transformadoras.

Acho que a possibilidade das discussões dos direitos sociais é novo nessa gestão. Nossa equipe técnica está fazendo um curso de violência doméstica, promovido pelo Conselho Municipal dos Direitos da Criança e do Adolescente e tem como parceria a Secretaria Municipal de Educação. Então, a preocupação com a formação do profissional, para poder atuar bem, tem sido evidente. Tudo isso é para capacitar o técnico para a população. E na Conferência Municipal de Assistente Social através do Fórum de Discussão, com a participação da sociedade, tivemos um curso de diversidade étnica que continuará no segundo semestre. Temos avaliado como um salto de qualidade. E nós que estamos preocupados com as diretrizes políticas das questões sociais acho que é fundamental para o nosso momento. (Margarida)

Por outro lado, a profissional Girassol desconhece a profissão de Serviço Social e arrisca-se em emitir um parecer da ausência de condições do profissional social em contribuir na elaboração de políticas educacionais que viabilizem uma educação de direito a todo cidadão. 
Eu não saberia dizer se o profissional tem uma contribuição específica na sua formação, para contribuir na elaboração da política educacional, não vejo de uma maneira tão cortada assim. Eu acho que na questão da educação todos tem como contribuir. Evidentemente, que cada um focaliza sua lanterna, sua luz a partir da sua especialização. Tem como contribuir na situação específica do assistente social, me parece que o foco serão nas condições de sobrevivência da família e como aquelas condições de sobrevivência deteriora relações e precisa ser recuperadas, o tecido social que precisa ser recomposto. E não vejo uma responsabilidade especial do assistente social, mas vejo uma responsabilidade na complexidade que é o processo educacional. (Girassol)

Diante de todos esses depoimentos apresentados pelos sujeitos da pesquisa e os profissionais que contribuíram com a mesma, evidencia-se em suas falas a importante tarefa da construção do perfil profissional no cenário educacional que começa a ser redesenhado. Isso porque existe uma história legitimada da intervenção do Serviço Social na Política Educacional no Brasil, e hoje se apresenta com nuances diferenciadas e intensas propostas de ampliação e efetivação de um trabalho de qualidade, inovador, com perspectivas transformadoras.

É muito positiva a fala de todos os entrevistados (sujeitos e profissionais) no que tange à construção e à presença de um perfil profissional na educação, pois revelam ser um profissional comprometido, competente, habilidoso, cuidadoso:

ela é uma pessoa muito calma, sabe o que faz. Tem uma fala muito calcada nos estudos que ela fez. Então falo com tranquilidade para você, nesses momentos em que nós temos a oportunidade de atuar juntos, eu cada vez aprendo mais. E para saber lidar melhor com outras pessoas até. (Orquídea)

para ser um bom profissional depende muito do ser humano que ele é. Isso em todas as profissões que nós temos. Você pode ter uma 
formação, formação continuada, mas depende da cultura dele. Eu entendo que assim é o profissional de Serviço Social, tem que ver o compromisso desse profissional, a formação cultural dele. Eu acho importante a formação inicial desse profissional da área social, acho que ele tem que ter uma base de formação, um núcleo comum para trabalhar, além da especificidade da área de Serviço Social e como toda profissão, a gente depende muito do profissional, e da cultura que ele tem, do que ele pode realmente estar colocando da profissão dele. (Rosa)

Caracteriza-se a profissão de Serviço Social por ser dinâmica e buscar transpor os limites de sua consciência histórica, compactuando com o novo e a busca da transformação social.

o assistente social é um profissional preparado para dar o encaminhamento necessário em diferentes casos, como ele conversa, dialoga, a forma como o assistente social aborda um pai, uma família, um usuário, é a forma extremamente técnica e acabam percebendo situações e evidências que nós leigos não percebemos Então, percebem atitudes que estão por trás da atitude do pai, da criança e da família. Por exemplo, tivemos um caso que a mãe não levava a criança no acompanhamento psicológico. E todo mundo falava, a mãe não leva, a mãe não leva... Então a Assistente Social viu que estava numa situação difícil financeira, desemprego e não tinha condições de levar. E neste diálogo com a assistente social foi percebido tudo isso. Foram tomados encaminhamentos juntamente com a Secretaria de Promoção Social e resolveu o problema, a criança está frequentando. (Hortência)

Segundo Pimenta (2002, p.19), a identidade profissional constrói-se a partir da significação social da profissão, da revisão constante dos significados sociais da profissão, da revisão das tradições. Nesse sentido, considera-se que a construção do perfil profissional do assistente social no cenário educacional está sendo realizada a partir do trabalho desenvolvido por este, no exercício profissional diário, 
enfim no compromisso ético-político, técnico-operativo e teóricometodológico assumido por ele.

Destaca-se a importância da atuação de um profissional crítico, ético, reflexivo, criativo, dinâmico, na compreensão da realidade social e de contradições, no enfrentamento das diversas expressões da questão social (violência, evasão escolar, fome, dificuldade no aprendizado e outras) que se manifestam no cotidiano escolar, com um sentido ético e político voltado para contribuir na luta pela igualdade social, pela cidadania e pela efetivação da democracia. 


\section{Conclusão}

"Quem para, retrocede"

Friedrich Nietzsche

O presente estudo sobre o Serviço Social na Educação do município de Barretos/SP não tem a pretensão de apresentar uma conclusão como um conhecimento acabado e ponto final de um trabalho social. Tendo em vista a riqueza de dados e fatos, a amplitude do tema, a dinamicidade dos trabalhos desenvolvidos pelos municípios estudados e outros indicadores de análise que surgiram após a realização dessa pesquisa, não cabe finalizá-la, pelo contrário, remete-se a algumas considerações compreendidas ao longo da investigação e que devem ser ponto de partida para outras pesquisas vinculadas ao objeto de estudo em questão.

A investigação trouxe reflexões acerca do trabalho desenvolvido pelos assistentes sociais no campo da educação, possibilitando refletir sobre a construção do perfil dos profissionais nesse trabalho, bem como o imprescindível trabalho interdisciplinar na educação.

Durante o percurso da pesquisa, houve a percepção de que não existe um modelo de intervenção profissional ou um perfil ideal de profissional, assistente social, que intervenha de forma que resolva todos os problemas sociais que a educação vive hoje. Existe, sim, um 
trabalho em construção, experiências interdisciplinares que assinalaram resultados positivos na efetivação dos direitos ao cidadão e no enfrentamento dos muitos problemas gerados pelas desigualdades sociais.

Nesse sentido, a presença do Serviço Social na Política Educacional com uma atuação que extrapole o ambiente escolar, deve trabalhar os diversos problemas que a instituição escolar enfrenta: a evasão escolar, a ausência dos pais no acompanhamento dos estudos dos filhos, a inadequação da escola face à realidade dos alunos (valores, material didático utilizado, padrões de comportamento e outros), uma estrutura educacional que nem sempre respeita seu educando e/ou lhe proporcione igualdade de condições para o acesso e a permanência na escola, bem como sua participação na definição das propostas educacionais, segundo o art. 53 do Estatuto da Criança e Adolescente (Lei 8.069/90), a repetência, a frequência irregular e a evasão escolar, associadas ao baixo rendimento do aluno, os fatores socioeconômicos das famílias, fatores de subnutrição, dentre outros.

O Assistente Social é um profissional qualificado e competente para contribuir na formulação e na articulação das políticas sociais públicas, com a organização e a mobilização da sociedade civil, bem como dos diversos profissionais, tendo em vista a garantia dos direitos sociais e do exercício da cidadania.

O trabalho fundamental do Assistente Social na Educação está em torno do engajamento na luta pela interação grupal, articulando formas de relações com os outros agentes da comunidade escolar na produção de novas alternativas de intervenção.

É necessário que essa relação seja vista em um contexto global de acumulação de capital e de divisão de classes sociais.

Nesta linha de raciocínio, Freire (1993) afirma que o trabalhador social, como homem, tem de fazer sua opção. "Ou adere à mudança que ocorre no sentido de verdadeira humanização do homem, de seu ser mais, ou fica a favor da permanência”.

Sendo assim, a instituição escola no entendimento do Serviço Social, enquanto campo de prática que rompe com a percepção de instituição apenas no aspecto formal e neutro para possibilitar uma 
análise institucional que desvende as relações informais, evidenciase como espaço de luta, pois, segundo Faleiros (2000), o desafio de enfrentar teoricamente a questão da prática institucional é tão complexo quanto a própria atuação, pois essa implica conflitos e confrontos de poderes e saberes.

É importante compreender que o contexto da política educacional direcionada à população infanto-juvenil nos municípios de Barretos e Osasco faz parte da realidade estrutural e conjuntural na qual estão inseridas as decisões políticas, econômicas e sociais e as contradições que permeiam essa realidade, impedindo a implementação das políticas sociais em especial a educação, que enfrenta grandes desafios tais como: evasão escolar, estrutura familiar que "joga" muitas vezes pelas ruas das cidades seus filhos, a existência de uma estrutura educacional de inclusão e de permanência do seu aluno, com resultados produtivos para um futuro promissor.

A política educacional do Brasil não tem alcançado um padrão de qualidade necessário, embora tenha sofrido mudanças radicais ao longo dos últimos anos cumprindo exigências internacionais, ocupando lugar de destaque no conjunto das ações governamentais federais que redesenham hoje a arquitetura institucional e o papel do Estado brasileiro, mantendo sua função estratégica no conjunto de transformações que se operam no mundo do trabalho na esfera da cultura que constitui um importante componente das alterações que atingem a educação no País.

$\mathrm{E}$, ainda, no que se refere à qualidade do ensino e ao sucesso escolar da maioria, o balanço de seu rendimento é seguramente insatisfatório, tendo permanecido o caráter excludente e seletivo do sistema educacional brasileiro no decorrer desse longo período.

Os "ciclos escolares" compreendem períodos de escolarização organizados em blocos cuja duração varia. Eles representam uma tentativa de superar a excessiva fragmentação do currículo que decorre do regime seriado durante o processo de escolarização.

A opção por este regime vem acompanhada por outras proposições: concepção de educação escolar obrigatória, desenho curricular, concepção de conhecimento e teoria de aprendizagem que fundamen- 
ta o ciclo, processo de avaliação, reforço e recuperação, composição de turmas, enfim, novas formas de ordenação dos tempos e espaços escolares que envolvem os diferentes atores afetados pelos ciclos.

Contudo, o ensino público brasileiro teve, nos últimos anos, muitos avanços. Atesta a porcentagem de crianças e de adolescentes em idade escolar que estão matriculados, a redução dos números de alunos com idade defasada em relação à série que estão cursando, o aumento das matrículas no Ensino Médio, a redução das taxas de repetência e evasão escolar. Não obstante, o acesso à escola não implica a permanência do aluno e tampouco a qualidade de ensino primordial.

De uma forma geral, esse perfil é resultado de uma política deliberada de fortalecimento da educação pública, implementada pelo Ministério da Educação e por muitas Secretarias Estaduais e Municipais de Educação e estes órgãos assumiram o desafio de reiniciar a reversão de um quadro perverso e desalentador de desigualdade social em que apenas a maioria que pode pagar ensino particular tem acesso à educação de qualidade.

É evidente que a educação é o fator-chave que impulsiona o desenvolvimento econômico e social do País. É por meio dela que qualquer jovem tem a oportunidade de melhorar seu padrão de vida e de encontrar um caminho digno para sua trajetória profissional e pessoal.

Exatamente por isso, educação pública deficiente é um fator perverso de concentração de renda e de perpetuação da desigualdade social. A escola pública conta com uma grande maioria dos alunos (no estado de São Paulo, cerca de 90\%). Se não há ensino público de qualidade, esse imenso contingente de pessoas será literalmente condenado ao ostracismo social e econômico.

Em 1990, o Brasil participou da Conferência Mundial de Educação para Todos, em Jomtien, na Tailândia, convocada pela Organização das Nações Unidas para a Educação, a Ciência e a Cultura (Unesco), Fundo das Nações Unidas para a Infância (Unicef), Programa das Nações Unidas para o Desenvolvimento (PNUD) e Banco Mundial. Dessa Conferência, assim como da Declaração de Nova Délhi, assinada pelos nove países em desenvolvimento de maior con- 
tingente populacional do mundo. Resultaram posições consensuais na luta pela satisfação das necessidades básicas de aprendizagem para todos, capazes de tornar universal a educação fundamental e de ampliar as oportunidades de aprendizagem para crianças, jovens e adultos.

Tendo em vista o quadro atual da educação no Brasil e os compromissos assumidos internacionalmente, o Ministério da Educação e do Desporto coordenou a elaboração do Plano Decenal de Educação para Todos (1993-2003), concebido como um conjunto de diretrizes políticas em contínuo processo de negociação, voltado para a recuperação da escola fundamental, a partir do compromisso com a equidade e com o incremento da qualidade, como também com a constante avaliação dos sistemas escolares, visando a seu contínuo aprimoramento.

O Plano Decenal de Educação, em consonância com o que estabelece a Constituição de 1988, afirma a necessidade e a obrigação de o Estado elaborar parâmetros claros no campo curricular capazes de orientar as ações educativas do ensino obrigatório, de forma a adequá-los aos ideais democráticos e à busca da melhoria da qualidade do ensino nas escolas brasileiras.

Em nível nacional, até dezembro de 1996, o Ensino Fundamental esteve estruturado nos termos previstos pela Lei Federal n ${ }^{0} 5.692$ de 11 de agosto de 1971. Definia como objetivo geral, tanto para o ensino fundamental (obrigatório) quanto para o ensino médio (não obrigatório), proporcionar aos educandos a formação necessária ao desenvolvimento de suas potencialidades como elemento de autorrealização, de preparação para o trabalho e para o exercício consciente da cidadania.

A nova Lei de Diretrizes e Bases da Educação Nacional (Lei Federal n 9.394), aprovada em 20 de dezembro de 1996, consolida e amplia o dever do poder público com a educação em geral e em particular para com o Ensino Fundamental. Assim, vê-se no art. 22 dessa Lei que a educação básica, da qual o Ensino Fundamental é parte integrante, deve assegurar a todos "a formação comum indispensável para o exercício da cidadania e fornecer-lhes meios para 
progredir no trabalho e em estudos posteriores", fato que confere ao Ensino Fundamental, ao mesmo tempo, um caráter de terminalidade e continuidade.

Verifica-se, pois, como os atuais dispositivos relativos à organização curricular da educação escolar caminham no sentido de conferir ao aluno, dentro da estrutura federativa, efetivação dos objetivos da educação democrática.

Não se pode deixar de levar em conta que, na atual realidade brasileira, a profunda estratificação social e a injusta distribuição de renda têm funcionado como um entrave para que uma parte considerável da população possa fazer valer seus direitos e interesses fundamentais. Cabe ao governo o papel de assegurar que o processo democrático se desenvolva de modo a que esses entraves diminuam cada vez mais. É papel do Estado democrático investir na escola, para que ela prepare e insira crianças e jovens no processo democrático, forçando o acesso à educação de qualidade para todos e às possibilidades de participação social.

Nesse estudo, trabalha-se com a certeza de que a criança, o adolescente e o jovem são sujeitos históricos e, assim, sujeito da construção e da transformação de sua história e dos sistemas sociais nos quais se encontram inseridos.

Para isso, faz-se necessária uma proposta educacional que tenha em vista a qualidade da formação a ser oferecida a todos os estudantes. $\mathrm{O}$ ensino de qualidade, que a sociedade demanda atualmente, expressa-se aqui como a possibilidade de o sistema educacional vir a propor uma prática educativa adequada às necessidades sociais, políticas, econômicas e culturais da realidade brasileira, que considere os interesses e as motivações dos alunos e garanta as aprendizagens essenciais para a formação de cidadãos autônomos, críticos e participativos, capazes de atuar com competência, dignidade e responsabilidade na sociedade em que vivem.

Desta forma, no início do século XXI, momento em que o Serviço Social avança nas discussões sobre seu projeto ético-político, a reflexão sobre a ação profissional é importante neste processo, pois evidencia a dimensão social e política da profissão. 
O Serviço Social, como profissão inserida na divisão sociotécnica do trabalho, por meio de seu compromisso com a construção de uma nova sociedade baseada na justiça e na equidade sem dominação e/ou exploração de classe, etnia e gênero, enfrenta o desafio de seu projeto defendendo como estratégia fundamental a defesa da qualidade dos serviços e o compromisso com os usuários em suas várias instâncias de atuação o que implica mediações diferenciadas entre Estado, burguesia e classe trabalhadora na implementação das políticas sociais destinadas a tratar a chamada "questão social", que surgiu com a implantação do sistema capitalista, e que, hoje, complexifica-se por meio das novas expressões do ideário neoliberal.

Acredita-se com este estudo que o profissional social consegue destacar-se na ação voltada para as questões sociais, pois pressupõe competência teórica, técnico-operativa e ético-política e com isso está atento ao movimento maior da sociedade, buscando compreendê-la e intervir de forma integrada com os demais profissionais.

Tem-se a partir da trajetória do Serviço Social a importância do profissional social na escola, bem como na política educacional, juntamente com seus diversos profissionais, no empenho do enfrentamento dos diversos problemas, tais como: a evasão escolar, a violência, o baixo rendimento escolar do aluno, o despreparo dos educadores direcionados a um saber conteudista e não um saber significativo e socialmente construído e a resistência marcada pelo desconhecimento do trabalho profissional do assistente social como colaborador nessa construção interdisciplinar para propor e efetivar ações transformadoras na escola e na política social de direito público que decidam o futuro das crianças e adolescentes que aí se encontram.

$\mathrm{Na}$ realidade dos municípios pesquisados, apesar de não serem tão gritantes como em algumas regiões do País, é possível constatar claramente por meio dessa investigação que estes sofrem os impactos dessa política imposta pelo capitalismo/neoliberalismo e que o direcionamento das políticas sociais, especialmente a educação, vem adquirindo um caráter seletivo e compensatório.

Depois de todas as reflexões realizadas voltadas ao conhecimento e à compreensão do cenário educacional e do Serviço Social, vale 
reforçar a importância de ações conjuntas, interdisciplinares na educação. E na construção de um sistema de ensino pautado na justiça, na igualdade e no entendimento dos sujeitos coparticipantes no processo de ensino-aprendizagem. Pois diante disso, pode-se visualizar o início de novos tempos, novas conquistas, novas oportunidades e novas batalhas em favor dos excluídos socialmente.

Ao finalizar essas reflexões, considera-se que muitas são as temáticas que deveriam ser examinadas em profundidade a partir dos conhecimentos construídos nessa pesquisa, considerando, sobretudo, o universo educacional como importante espaço de trabalho profissional para o Serviço Social.

Com isso, nesse momento de tantos problemas sociais, aqui apresentados, gerados pelas desigualdades econômicas, políticas, de não oportunidades no mundo do trabalho, de insuficiente qualidade profissional, o assistente social reflete criticamente sua formação acadêmica e sua prática profissional, tendo a certeza de que pode contribuir, com competência, com conhecimento teórico, com compromisso, com habilidade e atitude, para a efetivação desse direito social, a educação tão sonhada por tantas pessoas. 


\title{
REFERÊNCIAS BIBLIOGRÁFICAS
}

\author{
"A realidade pode ser mudada \\ só porque e só na medida em que \\ nós mesmos a produzimos, \\ e na medida em que saibamos \\ que é produzido por nós".
}

K. Kosik

ABEPSS. Associação Brasileira de Ensino e Pesquisa em Serviço Social. Formação do assistente social no Brasil e a consolidação do projeto ético-político. Serviço Social ES Sociedade, São Paulo, ano 25, n.79, p.72-81, set. 2004.

. Proposta básica para o projeto de formação profissional. Serviço Social E Sociedade, São Paulo: ano 17, n.50, p.143-71, abr. 1996.

ABESS/CEDEPSS. Diretrizes gerais para o curso de serviço social. Cadernos ABESS. São Paulo, n.7, p.58-76, 1997.

ABRAMIDES, M. B. C. Desafios do projeto profissional de ruptura com o conservadorismo. Serviço Social E Sociedade, São Paulo, ano 28, n.91, p.34-48, set. 2007.

ABREU, M. M. A dimensão pedagógica do serviço social: bases históricoconceituais e expressões particulares na sociedade brasileira. Serviço Social E Sociedade, São Paulo, ano 25, n.79, p.43-71, set. 2004.

ABREU, H.B. As novas configurações do Estado e da sociedade civil. In: Capacitação em Serviço Social e Política Social. Crise Contemporânea, 
Questão Social e Serviço Social. Brasília, DF: UnB, Centro de Educação Aberta, Continuada a Distância, módulo 1, p.35-44, 2000.

ALESSANDRINI, M. A inserção do assistente social na política educacional e na gestão da escola pública. Debates Sociais. São Paulo, ano 36, n. 59, p.61, 2001.

ALMEIDA, N. L. T. Educação. In: Capacitação em Serviço Social e Política Social: Política Social. Brasília, DF, UnB, Centro de Educação Aberta, Continuada a Distância, módulo 3, p.153-63, 2000a.

O Serviço social na educação. Inscrita, n.6. Brasília, DF: Cefess, p.19-22, 2000a.

Desafios contemporâneos para a formação profissional em serviço social. Social em Questão, Rio de Janeiro: PUC, Dep. de Serviço Social, v. 5, p.7-24, sem, 2000b.

. Serviço Social na educação: um breve balanço dos avanços e desafios desta relação. Palestra proferida no I Encontro de Assistentes Sociais na área de educação, no dia 28 de março de 2003 em Belo Horizonte. Disponibilizado pelo <www.cress-mg.org.br>. Acesso: 29/6/2004.

Parecer sobre os projetos de lei que dispõem sobre a inserção do serviço social na educação. Publicado no Caderno Especial n.26, 2004, em http://<www.assistentesocial.com.br>. Acesso: 20/6/2006.

ALMEIDA, N. L. T. et al. Proposta básica para o projeto de formação profissional: novos subsídios para o debate. Cadernos Abess. n.7. São Paulo, p.15-57, 1996.

AMARO, S. T. A. et al. Serviço social na escola: o encontro da realidade com a educação. Porto Alegre: Sagra Luzzatto, 1997.

ANDRADE, I. et al. Serviço Social português e brasileiro: a relação com o usuário. Serviço Social E Sociedade, São Paulo: ano 27, n.85, p.169-86, jun. 2007.

ANDRAUS, R. C. Olhando para o serviço social numa perspectiva interdisciplinar. Bauru: Edusc, 1996.

ANTUNES, R. Dimensões da crise e metamorfoses do mundo do trabalho. Serviço Social E Sociedade, São Paulo, ano 17 , n. 50, p.78-86, abr. 1996.

ARCOVERDE, A. C. B. Questão social no Brasil e serviço social. In: Capacitação em Serviço Social e Política Social, Reprodução social, trabalho e Serviço Social. Brasília, DF: UnB, Centro de Educação Aberta, Continuada a Distância, módulo 2, p.73-86, 2000.

AZEVEDO, M.C. Leste europeu: a inesperada convulsão. São Paulo: Loyola, 1991. 
BACKX, S. O serviço social na educação. In: REZENDE, I.; CAVALCANTI, L. F. Serviço Social e políticas sociais. 2.ed. Rio de Janeiro: UFRJ, p.121-37, 2008.

BACKHAUS, B. B. Prática do Serviço Social escolar: uma abordagem interdisciplinar. Serviço Social E Sociedade. São Paulo, ano 12, n.38, 1992. p.37-55.

BAPTISTA, M.V. A investigação em serviço social. São Paulo:Veras Editora, 2006 (Pesquisa 1).

BARDIN, L. Análise de conteúdo. Lisboa: Edições 70, 1977.

BARROCO, M. L. S. A inscrição da ética e dos direitos humanos no projeto ético-político do serviço social. Serviço Social E Sociedade, São Paulo, ano 25, n.79, p.27-42, set. 2004.

Ética e serviço social: fundamentos ontológicos. 2.ed. São Paulo: Cortez, 2003.

Os fundamentos sócio-históricos da ética. In: Capacitação em Serviço Social e Política Social. Reprodução social, trabalho e Serviço Social. Brasília, DF: UnB, Centro de Educação Aberta, Continuada a Distância, módulo 2, p.119-36, 2000.

BARROS, A. J. P. LEHFELD, N. A.S. Projeto de Pesquisa: propostas metodológicas. Petrópolis, RJ: Vozes, 2000.

BARROS, E. L. Os governos militares. 5.ed. São Paulo: Contexto, 1997.

BASTOS, M. D. F. Desafios atuais à formação universitária. Serviço Social E Sociedade, São Paulo, ano 16, n.47, p.5-16, abr. 1995.

BENEDITO, C. Dívida externa: quem paga? Petrópolis. Rio de Janeiro: Vozes, 2000.

BEHRING, E. R. Brasil em contra reforma: desestruturação do Estado e perda de direitos. São Paulo: Cortez, 2003.

. Política social no capitalismo tardio. 2.ed. São Paulo: Cortez, 2002.

. Principais abordagens teóricas da política social e da cidadania. In: Capacitação em Serviço Social e Política Social. Política Social. Brasília, DF: UnB, Centro de Educação Aberta, Continuada a Distância, módulo 3, p.19-40, 2000.

BEHRING, E. R.; BOSCHETTI, I. Política social: fundamentos e história. São Paulo: Cortez, 2006 (Biblioteca básica de serviço social; v.2).

BIANCHETTI, R. G. Modelo neoliberal e políticas educacionais. 4.ed. São Paulo: Cortez, 2005. (Questões de Nossa Época, 56).

BOFF, L. Depois de 500 anos: que Brasil queremos? Petrópolis, RJ: Vozes, 2000. 
BONETTI, D. A. et al. (Org.). Serviço social e ética: convite a uma nova práxis. Cfess. São Paulo: Cortez, 1996.

BOSCHETTI, I. O serviço social e a luta por trabalho, direitos e democracia no mundo globalizado, 2008. Disponível em <http://www.cfess.org.br> . Acesso em 23/09/2008.

BRANDÃO, C. R. O que é educação. São Paulo: Brasiliense, 2000.

BRASIL. Lei de Diretrizes e Bases da Educação Nacional. Lei 9394/96. Brasília, DF: MEC/SEF, 1997.

Parâmetros Curriculares Nacionais. Ministério da Educação e do Desporto. v.1 - Introdução. Brasília, 1997.

Parâmetros Curriculares Nacionais. Ministério da Educação e do Desporto. v. 8 - Apresentação dos temas transversais, ética. Brasília, 1997.

Estatuto da Criança e do Adolescente. Rio de Janeiro: Auriverde, 1990.

Constituição da República Federativa do Brasil. 27.ed. São Paulo: Saraiva, 2001 (Coleção Saraiva de Legislação).

BUCHA, A. I. O equacionamento da gestão escola. Estudos e Comunicação da Universidade Católica de Santos. Ano 30. n.81/82, p.57-61, mai-dez. 2004.

CAMARDELO, A.M. Estado, educação e serviço social: relações e mediações no cotidiano. Serviço Social \& Sociedade, São Paulo, ano 15, n.46, p.138-62, dez. 1994.

CANÔAS, J. W. (Org.). As transformações e os efeitos da globalização na sociedade. In: Atitudes operárias no processo de reestruturação produtiva do capital. Franca: Unesp, p.11-6, 2003.

O papel dos instrumentos de política econômica na obtenção da estabilidade e do crescimento no Brasil. In: A busca da canastra do mundo do trabalho. Franca: Unesp, p.191-6, 2005.

. Serviço Social e Educação. Serviço Social e Realidade. Franca, SP, v. 16, n.1, p.193-9, 2007.

CARDOSO, F. G.; MACIEL, M. Mobilização social e práticas educativas. In: Capacitação em Serviço Social e Política Social. Brasília, DF: UnB, Centro de Educação Aberta, Continuada a Distância, módulo 4, p.139-50, 2000.

CARVALHO, M. C. B. Famílias e políticas públicas. In: ACOSTA, A.R.; VITALE, M.A.F. Família: redes, laços políticas públicas. São Paulo: IEE/PUC/SP, p.267-74, 2003. 
CASTRO, M. M. História do serviço social na América Latina. 5.ed. Revista. São Paulo: Cortez, 2000.

CERQUEIRA FILHO, G. A questão social no Brasil: crítica do discurso político. Rio de Janeiro: Civilização Brasileira,1982.

CFESS. Conselho Federal de Serviço Social. Serviço social a caminho do século XXI: o protagonismo ético-político do conjunto CFESS-CRESS. Serviço Social E Sociedade, São Paulo, ano 17, n. 50, p.172-90, abr. 1996.

CHIZZOTTI, A. Pesquisa em ciências humanas e sociais. São Paulo: Cortez, 1995.

CORREIA, C. P. D. O papel da ética na construção do projeto políticoprofissional do assistente social. Serviço Social E Sociedade, São Paulo, ano 27, v.85, p.118-23, dez. 1992.

COSTA, L. C. Questão social e políticas sociais em debate. Sociedade em debate. Pelotas: Universidade Católica de Pelotas; Educat, v. 12, n.2, p.61-76, jul. dez, 2006.

COSTA, M. D. A política social e a formação para o serviço social: uma retrospectiva histórica. Estudos e Comunicação da Universidade Católica de Santos. Santos/SP, ano 24 , v.24, p.131-41, mai. 1998.

COUTINHO, N. Democracia e socialismo. São Paulo: Cortez, 1992.

COUTO, B. R. O direito social e a assistência social na sociedade brasileira: uma questão possível? São Paulo: Cortez, 2004.

CRUZ, D. R. F.et al. Perspectivas para serviço social no século XXI. Serviço Social E Sociedade, São Paulo, ano 1, n.1, p.80-91, set. 1979.

DEMO, P. Educação e qualidade. 2.ed. Campinas: Papirus, 1995.

Educação pelo avesso: assistência como direito e como problema. São Paulo: Cortez, 2000a.

Ironias da educação: mudanças e contos sobre mudança. Rio de Janeiro: DP\&A, 2000b.

Pesquisa: princípio científico e educativo. 7.ed. São Paulo: Cortez, 2000c.

Política social do conhecimento: sobre futuros do combate à pobreza. Petrópolis, RJ: Vozes, 2000d.

A nova LDB: ranços e avanços. 12.ed. Campinas/SP: Papirus, 2001.

DIEESE. Anuário dos Trabalhadores 2007. Brasília, 2007.

FALEIROS, V. P. A política social do estado capitalista. 8.ed. São Paulo: Cortez, 2000.

O serviço social no mundo contemporâneo. In: FREIRE, M. L. B. et al. Serviço social, política social e trabalho: desafios e perspectivas para o século XXI. Rio de Janeiro: Cortez, p.23-44, 2006. 
Confrontos teóricos do movimento de reconceituação do Serviço Social na América Latina. Serviço Social E Sociedade. São Paulo, ano 8, n.24, 1987. p.49-69.

. O que é política social. 5.ed. São Paulo: Brasiliense, 1991 (Primeiros Passos).

Reconceituação do serviço social no Brasil: uma questão em movimento? Serviço Social E Sociedade, São Paulo, ano 26, n.84, p.21-36, nov. 2005.

Serviço Social: questões presentes para o futuro. Serviço Social E Sociedade. São Paulo, ano 26, n.84, p.9-39, 1996.

FAUSTINI, M. S. A. O ensino no serviço social. Porto Alegre: EDIPUCRS, 2004.

FÁVERO, E. T. et al. O serviço social e a psicologia no judiciário: construindo saberes, conquistando direitos. São Paulo: Cortez, 2005.

FAZENDA, I. C. A. Interdisciplinaridade: história, teoria e pesquisa. 14.ed. Campinas/SP: Papirus, 1994.

. (Org.) Práticas interdisciplinares na escola. 7.ed. São Paulo, SP: Cortez, 2001.

Interdisciplinaridade: um projeto em parceria. 5.ed. Rio de Janeiro: Loyola, 2002.

Interdisciplinaridade: qual o sentido? São Paulo: Paulus, 2003.

FREIRE, M. L. et al (Org.). Serviço Social, politica social e trabalho: desafios e perspectivas para o século XXI. São Paulo: Cortez, 2006.

FREIRE, S. M. Estado, democracia e questão social no Brasil. In: PEREIRA, P. A. P. Política social e democracia. São Paulo, SP: Cortez, p.149-72, 2001.

FREIRE, P. Pedagogia do oprimido. 21.ed. Rio de Janeiro: Paz \& Terra, 1993.

FREITAG. B. Escola, estado e sociedade. 6.ed. rev. São Paulo: Moraes, 1986.

FRIGOTTO, G. Educação e a crise do capitalismo real. 4.ed. São Paulo: Cortez, 2000.

GADOTI, M. Concepção dialética da educação: um estudo introdutório. São Paulo: Cortez, 2001.

Educação e poder: introdução à pedagogia do conflito. 13.ed. São Paulo: Cortez, 2003.

Escola Cidadã. 9.ed. São Paulo: Cortez, 2003.

GENTILI, P. (Org). Pós-neoliberalismo: as políticas sociais e o Estado democrático. Rio de Janeiro: Paz e Terra, 1995. 
GENTILLI, R. M. L. Representações e práticas: identidade e processo de trabalho no Serviço Social. São Paulo: Veras, 1998.

GHIRALDELLI JÚNIOR. P. Filosofia e história da educação brasileira. Barueri/SP: Manole, 2003.

GIL, A. C. Métodos e técnicas de pesquisa social. 5.ed. São Paulo: Atlas, 2000. GOHN, M. G. Movimentos sociais e educação. São Paulo: Cortez, 2001.

GOMES, M. F. C. M. Avaliação de políticas sociais e cidadania: pela ultrapassagem do modelo funcionalista clássico. In: SILVA, M. O. DA S. (org.). Avaliação de políticas e programas sociais: teoria e prática. São Paulo: Veras, 2001.

GONSALVES, E.P. Iniciação à pesquisa científica. Campinas, SP: Alínea, 2001.

GUERRA, Y. O projeto profissional crítico: estratégia de enfrentamento das condições contemporâneas da prática profissional. Serviço Social E Sociedade, São Paulo, ano 28, n.91, p.5-33, set. 2007.

HARVEY, D. Condição pós-moderna. São Paulo: Loyola, 1999.

IAMAMOTO, M. V. Ensino e Pesquisa no Serviço Social: desafios na construção de um projeto de formação. Cadernos Abes, n.6, São Paulo: Cortez, p.101-6,1998

O trabalho do assistente social frente às mudanças do padrão de acumulação e de regulação social. In: Capacitação em Serviço Social e Política Social. Crise Contemporânea, Questão Social e Serviço Social. Brasília, DF: UnB, Centro de Educação Aberta, Continuada a Distância, módulo 1, p.111-28, 2000.

O serviço social na contemporaneidade: trabalho e formação profissional. São Paulo: Cortez, 2001.

Renovação e conservadorismo no Brasil. 6.ed. São Paulo: Cortez, 2002.

Questão social, família e juventude: desafios do trabalho do assistente social na área sócio-jurídica. In: SALES, M. A. et al. Política social, família e juventude: uma questão de direitos. São Paulo: Cortez, p.261-98, 2004.

. Serviço social em tempo de capital fetiche: capital financeiro, trabalho e questão social. São Paulo: Cortez, 2007.

IAMAMOTO, M. V.; CARVALHO, R. Relações sociais e serviço social no Brasil: esboço de uma interpretação histórico-metodológica. 17. ed. São Paulo: Cortez, 2005.

IANNI, O. O mundo do trabalho. In: FREITAS, M. C. (Org.). A reinvenção do futuro. 2.ed. São Paulo: Cortez, 1999. 
IPEA. Nota Técnica. Sobre a recente queda da desigualdade de renda no Brasil. Brasília, agosto de 2006. Disponível em <http://www.ipea.gov. br/default.jsp.> Acesso em 19/7/2008.

JOSÉ FILHO, Pe. M. A família como espaço privilegiado para a construção da cidadania. Franca: Unesp - FHDSS, 2002, 158 p. (Dissertações e Teses, n.5).

Pesquisa: contornos no processo educativo. In: JOSÉ FILHO, Pe. M; DALBÉRIO, O. Desafios da pesquisa. Franca: Unesp - FHDSS, p.63-75, 2006.

KARSCH, U. M. S. A produção acadêmica do assistente social: alguns pontos de vista sobre pesquisa. Serviço Social E Sociedade, São Paulo, ano 9, n.28, p.121-26, dez. 1988.

O serviço social na era dos serviços. 3.ed. São Paulo: Cortez, 1998.

KOIKE, M. As novas exigências teóricas, metodológicas e operacionais da formação profissional na contemporaneidade. In: Capacitação em Serviço Social e Política Social. Reprodução social, trabalho e Serviço Social. Brasília, DF: UnB, Centro de Educação Aberta, Continuada a Distância, módulo 2, p.101-18, 2000.

KUENZER, A. et al. Planejamento e educação no Brasil. 6.ed. São Paulo: Cortez, 2003.

LAURELL, A. C. (Org). Avançando em direção ao passado: a política social do neoliberalismo. In: Estado e Políticas sociais no neoliberalismo. 2.ed. São Paulo, SP: Cortez, p.151-78, 1997.

LIBÂNEO, J. C. et al. Educação escolar: políticas, estrutura e organização. 4.ed. São Paulo: Cortez, 2007. (Coleção Docência em Formação).

LOMBARDI, J. C. (Org). Globalização, pós-modernidade e educação: história, filosofia e temas transversais. 2.ed. Campinas/SP: Autores Associados: HISTEDBR: Caçador, SC: UnC 2003.

LÜCK, H. et al. A escola participativa: o trabalho do gestor escolar. 4.ed. Rio de Janeiro: DP\&A, 2000.

MANACORDA, M. A. História da educação: da Antiguidade aos nossos dias. 12.ed. São Paulo: Cortez, 2006.

MARTINELLI, M. L. Notas sobre mediações: alguns elementos para sistematização da reflexão sobre o tema. Serviço Social E S Sociedade, São Paulo, ano 14, n.43, p.136-41, dez. 1993.

Serviço social: identidade e alienação. São Paulo: Cortez, 2000.

MARTINELLI, M. L. O ensino teórico-prático do serviço social: demandas e alternativas. Serviço Social e Sociedade, São Paulo, ano 15, n.44, p.61-76, abr. 1994. 
O serviço social na transição para o próximo milênio: desafios e perspectivas. Serviço Social e Sociedade, São Paulo, ano 19, n.57, p.133-48, jul. 1998.

Pesquisa qualitativa: um instigante desafio. São Paulo: Veras, 1999.

MARX, K. Para a crítica da economia política, salário, preço e lucro; o rendimento suas fontes: economia vulgar. Trad. E. Malagodi. São Paulo: Abril Cultural, 1982 (Os Economistas).

MELO, A. I. S. C..; ALMEIDA, G. E. S. de. Interdisciplinaridade: possibilidades e desafios para o trabalho profissional. In: Capacitação em Serviço Social e Política Social. O trabalho do assistente social as políticas sociais. Brasília, DF: UnB, Centro de Educação Aberta, Continuada a Distância, módulo 4, p.225-39, 2000.

MESTRINER, M. L. O Estado entre a filantropia e a assistência social. 2.ed. São Paulo: Cortez, 2005.

MESZARÖS, I. Para além do capital. Campinas/SP: Boitempo, 2002.

MINAYO, M. C. S. (Org). Pesquisa Social: teoria, método e criatividade. 17.ed. Petrópolis, RJ: Vozes, 2000.

O desafio do conhecimento: pesquisa qualitativa em saúde. 8.ed. São Paulo: Hucitec, 2004.

MONTAÑO, C. A natureza do serviço social: um ensaio sobre sua gênese, a especificidade e sua reprodução. São Paulo: Cortez, 2007.

NETTO, J. P. Capitalismo monopolista e serviço social. São Paulo: Cortez, 1992.

Notas para a discussão da sistematização da prática e teoria em Serviço Social. Cadernos Abess, São Paulo, n.3, p.141-53, jul. 1995.

Transformações societárias e serviço social: notas para uma análise prospectiva da profissão no Brasil. Serviço Social E Sociedade, São Paulo, ano 17, n.50, p.87-132, abr. 1996.

A construção do projeto ético-político do serviço social frente à crise contemporânea. In: Capacitação em Serviço Social e Política Social. Crise Contemporânea, Questão Social e Serviço Social. Brasília, DF: UnB, Centro de Educação Aberta, Continuada a Distância, módulo 1, p.91-110, 2000.

Ditadura e serviço social: uma análise do serviço social no Brasil pós-64. 5.ed. São Paulo: Cortez, 2001.

A conjuntura brasileira: o serviço social posto à prova. Serviço Social E Sociedade, São Paulo, ano 25, v.79, p.5-26, set. 2004.

O movimento de reconceituação: 40 anos depois. Serviço Social E Sociedade, São Paulo, ano 26, n.84, p.5-20, nov. 2005. 
NETTO, J.P.; BRAZ, M. Economia política: uma introdução crítica. São Paulo: Cortez, 2006. (Biblioteca básica de serviço social, 1).

NEVES, L. M. W. Educação e política no Brasil de hoje. 3.ed. São Paulo: Cortez, 2002 (Coleção Questões da Nossa Época; v.36).

NICOLAU, M. C. C. Formação e fazer profissional do assistente social: trabalho e representações sociais. Serviço Social Ė Sociedade, São Paulo, ano 25, n.79, p.82-107, set. 2004.

NOSELLA, P. Os novos desafios para a educação popular no Brasil (Org). In: FREITAS, Marcos Cezar. A reinvenção do futuro. 2.ed. São Paulo: Cortez, 1999.

OLIVA, M. H. B. Política de estado e prática social. São Paulo: Cortez, 1987.

PÁDUA, E.M.M. Metodologia da pesquisa: abordagem teórico-prática. 2.ed. São Paulo: Papirus, 1997.

PASTORINI, A. Quem mexe os fios das políticas sociais? Avanços e limites da categoria "concessão-conquista". Serviço Social E Sociedade, São Paulo, ano 18, n.53, p.80-101, mar. 1997.

. A categoria: questão social em debate. São Paulo, SP: Cortez, 2004 (Questões da nossa época, v.19).

As políticas sociais e o serviço social: instrumento de reversão ou manutenção das desigualdades? In: MONTAÑO, C. A natureza do serviço social: um ensaio sobre sua gênese, a especificidade e sua reprodução. São Paulo: Cortez, 2006.

PAZ, R. D. O. Código de Ética: reafirmar a função pública de conselheiros e conselheiras. Serviço Social Ė Sociedade, São Paulo, ano 27, n.85, p.117-22, mar. 2006.

PEREIRA, P. A. P. A metamorfose da questão social e a reestruturação das políticas sociais. In: Capacitação em Serviço Social e Política Social. Crise Contemporânea, Questão Social e Serviço Social. Brasília, DF: UnB, Centro de Educação Aberta, Continuada a Distância, módulo 1, p.45-58, 2000a.

Necessidades humanas: subsídios à crítica dos mínimos sociais. São Paulo: Cortez, 2000b.

. (Org). Estado, regulação social e controle democrático. In: Política social e democracia. São Paulo, SP: Cortez, p.25-42, 2001.

A. Política social: temas e questões. São Paulo: Cortez, 2008.

PIANA, M.C.; CANÔAS, J. W. Educação: direito social a ser efetivado. Serviço Social e Realidade. Franca, SP, v. 16, n.1, p.201-18, 2007. 
PIMENTA, S.G. Formação de professores: identidade e saberes a docência. In: Saberes pedagógicos e atividade docente. 5.ed. São Paulo, Cortez, p.15-60, 2007.

PINHEIRO, M. E. Serviço social: documento histórico. São Paulo: Cortez, 1985.

PINTO, R.M.F. Política educacional e serviço social. São Paulo: Cortez, 1986.

PONTES, R. N. Mediação: categoria fundamental para o trabalho do assistente social. In: Capacitação em Serviço Social e Política Social. O trabalho do assistente social as políticas sociais. Brasília, DF: UnB, Centro de Educação Aberta, Continuada a Distância, módulo 4, p.3750, 2000.

Mediação e serviço social: um estudo preliminar sobre a categoria teórica e sua apropriação pelo serviço social. 3. ed. São Paulo: Cortez, 2002.

PRADO JUNIOR, C. História econômica do Brasil. 29. ed. São Paulo: Brasiliense, 1983.

RAICHELIS, R. Esfera pública e conselhos de assistência social: caminhos da construção democrática. São Paulo: Cortez, 1998.

Organização e gestão das políticas sociais no Brasil: desafios da gestão democrática das políticas sociais. In: Capacitação em Serviço Social e Política Social: Política Social. Brasília, DF, UnB, Centro de Educação Aberta, Continuada a Distância, módulo 3, p.59-70, 2000.

REZENDE, I. (Org.); CAVALCANTI, L.F. Serviço social e políticas sociais. 2.ed. Rio de Janeiro: Editora UFRJ, 2008.

RICO, E. M. (Org). Avaliação de políticas sociais: uma questão em debate. São Paulo, SP: Cortez, 1998.

RODRIGUES, M.R. O serviço social e a perspectiva interdisciplinar. In:

MARTINELLI, M.L. et al. O uno e o múltiplo nas relações entre as áreas do saber. 2.ed. São Paulo: Cortez, p.152-58, 1998.

RUDIO, F. V. Introdução ao projeto de pesquisa científica. Petrópolis: Vozes, 1986.

SÁ, J. L. M. S. de. Especialização versus interdisciplinaridade: uma proposta alternativa (um estudo sobre os cursos de pós-graduação no Brasil, enfocando a especialização em serviço social. In: SÁ, JEANETE L. MARTINS (Org.). Serviço Social e Interdisciplinaridade: dos fundamentos filosóficos à prática interdisciplinar no ensino, pesquisa e extensão. 3.ed. São Paulo: Cortez, 2000.

SACRISTÁN, J.G. O currículo: uma reflexão sobre a prática. 3.ed. Porto Alegre: Artmed, 2000. 
SANTANA, R. S. O desafio da implantação do projeto ético-político do Serviço Social. Serviço Social E Sociedade, São Paulo, ano, n.62, p.7392, mar. 2000.

SANTOS, J. S. Neoconservadorismo pós-moderno e serviço social brasileiro. São Paulo: Cortez, 2007. (Questões da nossa época; v.132).

SANTOS, B. S. Pela mão de Alice: o social e o político na pós-modernidade. São Paulo: Cortez, 1995.

SAVIANI, D. Educação: do senso comum à consciência filosófica. São Paulo: Cortez \& Autores Associados, 1982.

SEVERINO, A. J. Subsídios para uma reflexão sobre novos caminhos da interdisciplinaridade. In: SÁ, Jeanete L. Martins (Org.). Serviço Social e Interdisciplinaridade: dos fundamentos filosóficos à prática interdisciplinar no ensino, pesquisa e extensão. 3.ed. São Paulo: Cortez, 2000.

SHIROMA, E. O. et al. Política educacional. Rio de Janeiro: DP\&A, 2000. SILVA, A. A. As relações Estado-sociedade e as formas de regulação social. In: Capacitação em Serviço Social e Política Social. Reprodução social, trabalho e Serviço Social. Brasília, DF: UnB, Centro de Educação Aberta, Continuada a Distância, módulo 2, p.55-71, 2000.

Um novo fazer profissional. In: Capacitação em Serviço Social e Politica Social. O trabalho do assistente social e as políticas sociais. Brasília, DF: UnB, Centro de Educação Aberta, Continuada a Distância, módulo 4, p.111-24, 2000.

Gestão da seguridade social brasileira: entre a política pública e o mercado. São Paulo: Cortez, 2004.

SILVA, M.O.S. A crise dos projetos de transformação social e a prática profissional do Serviço Social. Serviço Social Ė Sociedade, São Paulo, ano 27, n.85, p.101-17, dez. 1992.

. O serviço social na conjuntura brasileira: demandas e respostas. Serviço Social E Sociedade, São Paulo, ano 15, n.44, p.77-113, abr. 1994.

Formação profissional do assistente social. 2.ed. São Paulo: Cortez, 1995. Avaliação de políticas sociais: concepção e modelos analíticos. Serviço Social É Sociedade, São Paulo, ano 18, n.53, p.74-9, mar. 1997.

Execução e avaliação de políticas e programas sociais. In: Capacitação em Serviço Social e Política Social. O trabalho do assistente social e as políticas sociais. Brasília, DF: UnB, Centro de Educação Aberta, Continuada a Distância, módulo 4, p.65-78, 2000.

SILVA, M. O. S. et al. A política social brasileira no Século XXI: a prevalência dos programas de transferência de renda. São Paulo: Cortez, 2004. 
SIMIONATO, I. As expressões ideoculturais da crise capitalista da atualidade. In: Capacitação em Serviço Social e Política Social. Crise Contemporânea, Questão Social e Serviço Social. Brasília, DF: UnB, Centro de Educação Aberta, Continuada a Distância, módulo 1, p.77-90, 2000.

SIMÕES NETO, J. P. Assistentes sociais e religião: um estudo Brasil/ Inglaterra. São Paulo: Cortez, 2005.

SOARES, J. A.; BAVA, S. C. (Org.) Os desafios da gestão municipal democrática. 2.ed. São Paulo: Cortez, 2002.

SOUZA NETO, J. C. De menor a cidadão: filantropia, genocídio, políticas assistenciais. São Paulo: Nuestra América, 1993.

SPOSATI, A. Serviço social em tempos de democracia. Serviço Social $\mathcal{E}$ Sociedade, São Paulo, ano 13, n.39, p.5-30, ago. 1992.

SPOSATI. Globalização da economia e processos de exclusão social. In: Capacitação em Serviço Social e Política Social. Crise Contemporânea, Questão Social e Serviço Social. Brasília, DF: UnB, Centro de Educação Aberta, Continuada a Distância, módulo 1, p.61-76, 2000.

STEIN, R.H. A descentralização como instrumento de ação política e suas controvérsias (revisão teórico-conceitual). Serviço Social E Sociedade, São Paulo, ano 18, n.54, p.75-96, jul. 1997.

Implementação de políticas sociais e descentralização político-administrativa. In: Capacitação em Serviço Social e Política Social: Política Social. Brasília, DF, UnB, Centro de Educação Aberta, Continuada a Distância, módulo 3, p.73-85, 2000.

TEIXEIRA, J. B. Política social e serviço social. Serviço Social E̋ Sociedade, São Paulo, ano 25, n.1, p.65-79, set. 1979.

TORRES, I. C. As primeiras-damas e a assistência social: relações de gênero e poder. São Paulo: Cortez, 2002.

TRIVIÑOS, A. N.S. Introdução à pesquisa em ciências sociais: a pesquisa qualitativa em educação. São Paulo: Atlas, 1987.

VASCONCELOS, A. M. Estado e políticas sociais no capitalismo: uma abordagem marxista. Serviço Social E Sociedade, São Paulo, ano 9, n.28, p.5-32, dez. 1988.

. O trabalho do assistente social e o projeto hegemônico no debate profissional. In: Capacitação em Serviço Social e Política Social. O trabalho do assistente social e as políticas sociais. Brasília, DF: UnB, Centro de Educação Aberta, Continuada a Distância, módulo 4, p.125-37, 2000.

A prática do serviço social: cotidiano, formação e alternativas na área da saúde. 2.ed. São Paulo: Cortez, 2003. 
VIEIRA, B. O. História do serviço social: contribuição para a construção de sua teoria. Rio de Janeiro: Agir, 1977.

VIEIRA, B. Serviço social: visão internacional. Rio de Janeiro: Agir, 1982.

VIEIRA, E. Democracia e política social. São Paulo: Cortez, 1992. (Polêmicas do nosso tempo, 49).

Estado e miséria social no Brasil: de Getúlio a Geisel 1951-1978. 4.ed. São Paulo: Cortez, 1995. 240 p.

As políticas sociais e os direitos sociais no Brasil: avanços e retrocessos. Serviço Social Ė Sociedade, São Paulo, ano 18, n.53, p.67-79, mar. 1997. Os direitos e a política social. 2.ed. São Paulo: Cortez, 2007.

VIEIRA, S. L.; FARIAS, I. M. S. Política educacional no Brasil: introdução histórica. Brasília: Líber Livro, 2007.

WANDERLEY, L. E. W. Educação e cidadania. Serviço Social E Sociedade, São Paulo, ano 21, n.62, p.156-67, mar. 2000.

YASBEK, M. C. et al. O serviço social brasileiro em movimento: fortalecendo a profissão na defesa de direitos. Serviço Social \& Sociedade, São Paulo, ano 29, n.95, p.5-32, set. 2008.

YASBEK, M. C. A escola de serviço social de São Paulo no período de 1936 a 1945. Cadernos PUC, São Paulo: Cortez, n.6, p.11-59, dez. 1980.

. Classes subalternas e assistência social. 2.ed. São Paulo: Cortez, 1996.

O serviço social como especialização do trabalho coletivo. In: Capacitação em Serviço Social e Política Social. Reprodução social, trabalho e Serviço Social. Brasília, DF: UnB, Centro de Educação Aberta, Continuada a Distância, módulo 2, p.87-99, 2000.

Os fundamentos do serviço social na contemporaneidade. In: $\mathrm{Ca}$ pacitação em Serviço Social e Política Social. . O trabalho do assistente social e as políticas sociais. Brasília, DF: UnB, Centro de Educação Aberta, Continuada a Distância, módulo 4, p.19-34, 2000 b.

ZAUITH, C. Barretos: da origem ao núcleo histórico. Soares de Oliveira: Barretos, 1993.

\section{Sites da Internet pesquisados e citados}

ASSISTENTE SOCIAL. Disponível em: <http://www.assistentesocial. com.br>. Acesso 05/08/2005.

BARRETOS. Disponível em: <http://www.barretos.sp.gov.br > Acesso em 26/07/2008. 
CAMARA. Disponível em: <http://www.camara.gov.br>. Acesso em 14/10/2008.

CFESS. Disponível em: <http://www.cfess.org.br>. Acesso em 13/10/2008.

CRESS. Disponível em: <http://www.cress-sp.org.br>. Acesso em 21/8/2008.

IBGE. Disponível em: <http://www.ibge.org.br>. Acesso em 25/8/2008. 


\author{
SOBRE O LIVRO \\ Formato: $14 \times 21 \mathrm{~cm}$ \\ Mancha: 23,7 x 42,5 paicas \\ Tipologia: Horley Old Style 10,5/14 \\ 1 a edição: 2009 \\ EQUIPE DE REALIZAÇÃO \\ Coordenação Geral \\ Marcos Keith Takahashi
}


CULTURA

ACADÊMICA 